\title{
Expedition 316 Site C0006 $^{1}$
}

\author{
Expedition 316 Scientists $^{2}$
}

\section{Chapter contents}

Background and objectives.......... 1

Operations................... 2

Lithology ................. 2

Structural geology. .............6

Biostratigraphy ................ 9

Paleomagnetism ............... 12

Inorganic geochemistry . . . . . . . 13

Organic geochemistry. . . . . . . . . . . 19

Microbiology and biogeochemistry . . . . . . 19

Physical properties .............. 20

References...................... . 25

Figures.................. 27

Tables.................... 86

${ }^{1}$ Expedition 316 Scientists, 2009. Expedition 316 Site C0006. In Kinoshita, M., Tobin, H., Ashi, J., Kimura, G., Lallemant, S., Screaton, E.J., Curewitz, D., Masago, H., Moe, K.T., and the Expedition 314/315/316 Scientists, Proc. IODP, 314/315/316: Washington, DC (Integrated Ocean Drilling Program Management International, Inc.). doi:10.2204/iodp.proc.314315316.134.2009 ${ }^{2}$ Expedition 314/315/316 Scientists' addresses.

\section{Background and objectives}

Integrated Ocean Drilling Program (IODP) Site C0006 (proposed Site NT1-03B; Kimura et al., 2007) targets the main frontal thrust at the seaward edge of the accretionary prism (Figs. F1, F2). Based on seismic data and submersible studies, this thrust was interpreted to have placed moderately consolidated (and presumably older) clastic rocks over weak and unlithified late Quaternary trench section clastic sediments (Ashi et al., 2002). The scientific objectives of drilling at Site C0006 are to clarify the evolution of the frontal thrust from its birth to death, the function of the frontal thrust with respect to large earthquakes, and the relationship between fluid behavior, slip, and deformation within this fault zone.

Site C0006 was first drilled during IODP Expedition 314 (see the "Expedition 314 Site C0006" chapter), and logging-whiledrilling (LWD) logs were obtained to $885.5 \mathrm{~m}$ logging depth below seafloor (LSF). During IODP Expedition 316, coring was completed to $603 \mathrm{~m}$ core depth below seafloor (CSF). Poor hole conditions stopped drilling at this site before the frontal thrust was reached.

During Expedition 314, four primary logging units were defined in IODP Hole C0006B based on visual inspection of the gamma ray, resistivity, and caliper log responses:

1. Logging Unit I (0-198 m LSF) is interpreted as sandy and muddy sediments.

2. Logging Unit II (198-428 m LSF) is interpreted as a mudstone with thick sandstone.

3. Logging Unit III (428-711 m LSF) is interpreted as alternating beds of mudstone and sandstone (base marked by a large fault zone).

4. Logging Unit IV (711 m LSF to total depth [TD]) is below the inferred fault zone and interpreted as sandstone.

Core samples from Expedition 316 drilling at this site will be integrated with the existing three-dimensional (3-D) seismic and LWD results to characterize physical properties, strength, composition, and structure of the hanging wall, frontal thrust, and footwall at this site. In situ temperature data were also collected to assess the thermal gradient and heat flow in this area. 


\section{Operations}

\section{Positioning on Site $\mathrm{C0006}$}

The D/V Chikyu arrived at Site C0006 on 27 December 2007 and began testing the underwater television system (UWTV). Electronics problems forced cancellation of that test, and positioning over Hole C0006C began at $1200 \mathrm{~h}$ on 28 December. The hydraulic piston coring system (HPCS) bottom-hole assembly (BHA) was rigged up and run to the seafloor, and Hole C0006C was tagged at 1915 h on 28 December.

\section{Hole C0006C}

Because of the lack of a camera system or remotely operated vehicle (ROV) observation, collection of a mudline core had to be accomplished by trial and error. One HPCS core $(316-\mathrm{C} 0006 \mathrm{C}-1 \mathrm{H})$ was taken at $1915 \mathrm{~h}$ on 28 December $2007\left(33^{\circ} 1.6458^{\prime} \mathrm{N}\right.$, $136^{\circ} 47.6282^{\prime} \mathrm{E}$; seafloor $=3880.5 \mathrm{~m}$ mud depth below sea level [MSL]), resulting in full recovery, which required repositioning and reshooting in order to collect the mudline.

\section{Hole C0006D}

One HPCS core (316-C0006D-1H) was taken in Hole $\mathrm{C} 0006 \mathrm{D}\left(33^{\circ} 1.6431^{\prime} \mathrm{N}, 136^{\circ} 47.6282^{\prime} \mathrm{E}\right.$; seafloor = $3877.5 \mathrm{~m} \mathrm{MSL}$ ) at $2245 \mathrm{~h}$ on 28 December 2007, resulting in full recovery with no mudline. The vessel was again repositioned.

\section{Hole C0006E}

Core 316-C0006E-1H was collected at $0000 \mathrm{~h}$ on 29 December 2007, resulting in $5.19 \mathrm{~m}$ of recovery, including the mudline in Hole C0006E $\left(33^{\circ} 1.6444^{\prime} \mathrm{N}\right.$, $136^{\circ} 47.6282^{\prime} \mathrm{E}$; seafloor $\left.=3875.81 \mathrm{~m} \mathrm{MSL}\right)$. HPCS coring continued from 5.19 m CSF. We collected 14 HPCS cores with total recovery of $83.54 \mathrm{~m}$ (average recovery $=105.31 \%)$. Advanced piston coring temperature tool (APCT3) measurements were taken every other core starting at the third core (316C0006E- $3 \mathrm{H}, 5 \mathrm{H}, 8 \mathrm{H}, 10 \mathrm{H}, 12 \mathrm{H}$, and $14 \mathrm{H})$. Refusal (no penetration) occurred at Core 316-C0006E-14H, and HPCS coring was halted.

Extended shoe coring system (ESCS) coring commenced at that time, resulting in the recovery of 35 cores (316-C0006E-15X through 49X) with total recovery of $330.11 \mathrm{~m}$ at a rate of $74.76 \%$. Six DavisVillinger Temperature Probe (DVTP) measurements were made following Cores 316-C0006E-23X, 26X, $28 \mathrm{X}, 29 \mathrm{X}, 35 \mathrm{X}$, and $42 \mathrm{X}$. Three of the DVTP runs were unsuccessful because of battery failure, thermistor failure, and failure to penetrate formation following Cores 316-C0006E-23X, 28X, and 42X, respectively.
After observing a drastically reduced rate of penetration during the cutting of Core 316-C0006E-49X, we determined that refusal had been reached, and Hole C0006E was completed at $409.4 \mathrm{~m} \mathrm{CSF}$ at $1930 \mathrm{~h}$ on 6 January 2008. We killed Hole C0006E with highdensity mud, pulled the BHA out of the hole, tripped the drill pipe, and racked back the HPCS/ESCS BHA. During this time, an electrical problem with the wireline winch motor required that Core 316C0006E-49X be recovered after recovering the BHA on the rig floor. This occurred at $0330 \mathrm{~h}$ on $7 \mathrm{Janu}-$ ary. Table T1 shows the cores collected, meters recovered, and recovery percentage for Holes C0006C, C0006D, and C0006E.

\section{Hole C0006F}

The Chikyu then relocated to Hole C0006F and the rotary core barrel (RCB) BHA was run to the seafloor. Hole C0006F $\left(33^{\circ} 1.6242^{\prime} \mathrm{N}, 136^{\circ} 47.6282^{\prime} \mathrm{E}\right.$; water depth $=3875.5 \mathrm{~m} \mathrm{MSL}$ ) was tagged at $1730 \mathrm{~h}$ on 7 January 2008. We conducted jet-in to $50 \mathrm{mbsf}$ and washed to 395 mbsf. RCB coring operations began, and 23 RCB cores were recovered (Cores 316C0006F-1R through 23R) from 395 to $603 \mathrm{~m} \mathrm{CSF}$ with total recovery of $56.48 \mathrm{~m}$ at a rate of $27.15 \%$.

Following collection of Core 316-C0006F-23R, it was determined based on pump rates, pressure, torque, and rotations per minute (rpm) that the hole condition had deteriorated to such a degree as to make further coring too risky. As pumping rate increased, the torque increased to the point of stalling the top drive (0 rpm); as pump rates dropped, torque would simultaneously drop and rpm would increase. The only way to get the bit back to the bottom of the hole was to run in the hole with $<10$ strokes per minute, which was considered unacceptably risky for either drilling or coring. The decision was made at $\sim 0900 \mathrm{~h}$ on 13 January to abandon Site C0006 and relocate to proposed Site NT1-03A as an alternative means to achieve the science goals for the NT1-03 family of sites. We killed Hole C0006F with high-density mud, pulled the BHA out of the hole, tripped the drill pipe, and racked back the RCB BHA at $2100 \mathrm{~h}$ on 13 January. Table $\mathrm{T} 2$ shows the cores collected, meters recovered, and recovery percentage for Hole C0006F.

\section{Lithology}

Three lithologic units were recognized during examination of cores from Site C0006 (Fig. F3; Table T3). Four subunits are recognized in Unit II. Units and subunits are differentiated based on contrasts in grain size, mineralogy, composition, and presence (and thickness) of sand and ash layers. In choosing unit boundaries, we also considered biostratigraphic 
information, paleomagnetic data, X-ray computed tomography (CT) images, observations of structural style, and interpretations of LWD and seismic results obtained during Expedition 314 (see the "Expedition 314 Site C0006" chapter). Numerous thrust faults offset the succession at Site C0006 with duplication of stratigraphic intervals. Thus, true stratigraphic thicknesses are difficult to determine and the estimates given here are maxima.

\section{Unit I (trench to slope transition facies)}

Interval: Sections 316-C0006E-1H-1, $0 \mathrm{~cm}$, through $4 \mathrm{H}-3,20 \mathrm{~cm}$

Depth: Hole C0006E $=0.00-27.23 \mathrm{~m} \mathrm{CSF}$

Age: Pleistocene

The dominant lithology of Unit I is greenish gray silty clay that contains clay, quartz, feldspar, lithic fragments, vitric fragments, and calcareous nannofossils (Fig. F3; Table T3). Calcite content is an important defining characteristic of this unit, ranging from $0 \%$ to $7.5 \%$ and averaging $2 \%$. In LWD data from Expedition 314, the corresponding interval was not logged with the resistivity tool and was included in a logging unit that largely corresponds to lithologic Unit II. Unit I consists of a fining-upward succession of silty clay, sand, silty sand, and rare volcanic ash layers. The mud is structureless and locally has green color banding. Sand and silty sand are extensively disrupted by a coring disturbance that locally creates mixtures of sand and mud. Lower in the unit, thin to thick beds with sharp bases and graded tops fine upward into the overlying mud. Generally, sand layers are thinner in the upper part of the unit. The sand component is mainly fine to very fine grained and consists of quartz, feldspar, lithic grains, and vitric fragments. A $1.25 \mathrm{~m}$ thick layer of light olivegray volcanic ash with abundant pumice fragments occurs near the base of the unit.

The contact between Unit I and underlying Subunit IIA is distinguished by the first appearance of thicker beds $(>50 \mathrm{~cm}$; Fig. F3B) of black sand below and the increase in mud content above the unit boundary. Deposition occurred on the lowermost slope above the trench floor by hemipelagic settling, onlap of axial turbidity currents that decreased through time, and accumulation of a thick ash.

\section{Unit II (trench deposits)}

Intervals: Sections 316-C0006E-4H-3, $20 \mathrm{~cm}$, through 49X-CC, $21 \mathrm{~cm}$, and 316-C0006F$1 \mathrm{R}-1,0 \mathrm{~cm}$, through 7R-CC, $21 \mathrm{~cm}$

Depths: Hole C0006E $=27.23-406.95 \mathrm{~m} \mathrm{CSF}$ and Hole C0006F $=395.00-449.67 \mathrm{~m} \mathrm{CSF}$

Age: Pleistocene
Unit II is divided into four subunits based mainly on variations in silt and sand content (Fig. F3; Table T3). Lithologic variations in the cores, however, do not precisely correspond to these arbitrary or gradational divisions, and it was considered more appropriate to group them into a single unit with a general coarsening upward trend relating to a progressive increase in silt and sand content upsection. A similar coarsening upward trend is noted in the accreted trench deposits of the Nankai margin described by Moore and Karig (1976). The large variations in X-ray diffraction (XRD) data throughout this section (Tables T4, T5) can be partially attributed to the varied lithologies sampled (sand to silty clay; Figs. F3B, F4).

Unit II is also structurally complex, with numerous thrust faults causing significant repetition of the sequence (see "Structural geology" and "Biostratigraphy"). Although the exact positions of these faults are uncertain, they have been tentatively placed on the summary stratigraphic section (Fig. F3).

\section{Subunit IIA (sand-dominated trench wedge)}

Interval: Sections 316-C0006E-4H-3, $20 \mathrm{~cm}$, through $12 \mathrm{H}-2,10 \mathrm{~cm}$

Depth: Hole C0006E = 27.23-72.06 m CSF

Age: Pleistocene

The dominant lithology of Subunit IIA is dark gray to black fine-grained sand consisting of metamorphic and volcanic lithic fragments with secondary quartz and feldspar. Individual beds are generally 1-7 m thick and massive, although any original sedimentary structures may have been destroyed by coring. Sand typically grades upward into silt and locally silty clay with indistinct boundaries between the different lithologies. Sand beds have sharp bases (Fig. F5). Silty clay interbeds are typically $<1 \mathrm{~m}$ thick with minor sandy silt and clayey silt intervals also present.

Clay content ranges from $28.5 \%$ to $55 \%$ and averages $42 \%$. Quartz content ranges from $20 \%$ to $29 \%$ and averages $24.1 \%$, and plagioclase ranges from $21 \%$ to $46 \%$ and averages $33 \%$. Calcite in this unit is below detection by XRD in most samples (only four samples contain calcite), ranging up to 3\% (Fig. F4).

The high sand content of this subunit is suggestive of an axial channel deposit.

\section{Subunit IIB (mixed sand-mud trench wedge) \\ Interval: Sections 316-C0006E-12H-2, $10 \mathrm{~cm}$, through 24X-1, $0 \mathrm{~cm}$ \\ Depth: Hole C0006E $=72.06-163.33$ m CSF \\ Age: Pleistocene}

Subunit IIB consists of interbedded fine-grained sand, silty sand, and silty clay in approximately 
equal abundances. The sand content of this subunit is markedly diminished compared to overlying Subunit IIA (Fig. F3B). Dark gray fine-grained sands and dark olive-gray silts are dominated by metamorphic and volcanic lithic grains with secondary quartz (averaging $25 \%$ by XRD) and plagioclase (averaging $31 \%$ by XRD), although the proportion of lithic fragments decreases in very fine sand and silt. Sand beds are typically normally graded with indistinct upper boundaries that grade into silty clay. The silty clay is greenish gray and is only slightly bioturbated or mottled in places. Carbonate content is below detection by XRD. Minor ash and carbonate-cemented tuff exist in the upper portions of this subunit (see description of carbonate-cemented ash below). Interpretation of this subunit was hampered by poor core recovery, possibly indicating substantial loss of the sand units shown by LWD logs (see the "Expedition 314 Site C0006" chapter).

\section{Subunit IIC (mud-dominated trench wedge)}

Interval: Sections 316-C0006E-24X-1, $0 \mathrm{~cm}$, through 48X-1, $0 \mathrm{~cm}$

Depth: Hole C0006E $=163.33-391.33 \mathrm{~m} \mathrm{CSF}$

Age: Pleistocene

The dominant lithology of Subunit IIC is greenish gray silty clay and minor lithologies include normally graded silt, sand, and rare ash. Within the coarser siliciclastic beds, silt is generally more abundant than sand, particularly when compared to Subunit IIA (Fig. F3B). The silty clay is slightly bioturbated and mottled in places, with local Chondrites burrows. Sand and silt beds are typically graded with indistinct upper boundaries and commonly exhibit parallel laminae and locally well-formed crosslaminae. They are typically $5-25 \mathrm{~cm}$ thick, although sand beds up to $5 \mathrm{~m}$ thick have also been identified (with their tops at 230, 247, 326, and $369 \mathrm{~m} \mathrm{CSF}$ ). The lowermost of these contains abundant organic matter and wood fragments (up to 50\%) with individual fragments up to $3 \mathrm{~cm}$ across (Fig. F6). This bed coincides with the base of a significant fault and shows various structures indicating sand remobilization and injection.

Compositionally, this subunit is similar to Subunit IIB with the exception of a slightly greater calcite content (ranging from $0 \%$ to $12 \%$ and averaging $\sim 1 \%$ ) as determined by XRD.

\section{Subunit IID (deep marine basin to mud- dominated trench transition)}

Intervals: Sections 316-C0006E-48X-1, $0 \mathrm{~cm}$, through 49X-CC, $21 \mathrm{~cm}$, and 316-C0006F$1 \mathrm{R}-1,0 \mathrm{~cm}$, through 7R-CC, $33.5 \mathrm{~cm}$
Depths: Hole C0006E $=391.33-406.95 \mathrm{~m} \mathrm{CSF}$ and Hole C0006F $=395.00-449.67 \mathrm{~m} \mathrm{CSF}$

Age: Pleistocene

The dominant lithology of Subunit IID is greenish gray silty clay, and minor lithologies include silt and ash. Silt layers are thin-bedded; they are relatively rare in this section and absent below $405 \mathrm{~m}$ CSF. Sand beds are completely absent from this subunit. Ash layers are relatively abundant in comparison with overlying units (Fig. F7). The silty clay typically exhibits green (glauconitic?) color bands, which increase in frequency toward the base of the subunit. Mottling and slight to moderate bioturbation are common, but positive identification of Chondrites burrows is limited to the upper part of the subunit. A pronounced increase in the relative abundance of calcite in the XRD data (up to 13\%; Fig. F4) appears to correspond to a zone of abundant foraminifer tests in the core (up to $8 \%$ in smear slides) in the lowermost part of the subunit.

Except for minor variations in calcite content, Subunits IIB, IIC, and IID manifest no prominent depthdependent or age-dependent trends in composition as determined from XRD (Fig. F4). X-ray fluorescence (XRF) analysis was applied to a subset of samples spanning these three subunits in an effort to find compositional trends related to the clay fraction (see "X-ray fluorescence" in the "Expedition 316 methods" chapter). Variations in the silt/clay ratio potentially provide a source of elemental variation that is large enough to mask trends related specifically to clay minerals, so the sample set for XRF (33 samples) was selected to include only a narrow range in the total clay content $(48.0 \%-54.0 \%$ clay minerals). Despite this effort to constrain sources of elemental variation, no depth trends were detected in 10 of the 11 elements analyzed. Only P (Fig. F8) shows a subtle decreasing trend with depth that may reflect decreasing environmental oxygenation in areas more remote from persistent bottom currents, an interpretation that is consistent with the abundant pyrite observed in deeper mudstones.

Unit II is interpreted as having been deposited in a trench setting, with increasing proximity to the axial portion of the trench upsection.

\section{Unit III (deep-marine basin)}

Interval: Sections 316-C0006F-7R-CC, $33.5 \mathrm{~cm}$, through 23R-CC, $21 \mathrm{~cm}$

Depth: Hole C0006F = 449.67-603.00 m CSF

Age: early Pleistocene-late Miocene

Unit III is $140.06 \mathrm{~m}$ thick (Fig. F3; Table T3), although this thickness is exaggerated by repetition of parts of the unit along thrust faults (see "Structural 
geology"). The unit (Fig. F9) consists of greenish gray to grayish silty clay with some interbedded volcanic tuff layers, including dolomite-cemented and calcite-cemented ash (see below). Bioturbation is widespread, particularly in the upper part of the unit with Zoophycos, Chondrites, other types of burrows, and color mottling. Green color bands are also abundant in the upper part of the unit. The silty clay consists mainly of clay with quartz, feldspar, and minor to rare calcareous nannofossils. Clay content of the silty clay (averaging 51\% for the unit) increases downhole, and its color changes from greenish gray (Fig. F9A) to gray at $561.5 \mathrm{~m}$ CSF (Fig. F9B). Unit III has an overall increased clay mineral content and decreased quartz and feldspar content (averaging $22 \%$ and $25 \%$, respectively) compared to overlying Subunit IID (Fig. F4). Volcanic ash layers are white to light gray, at least partly laminated, with sharp lower and diffuse upper contacts, and are locally burrowed. They consist mainly of glass with minor pumice, quartz, feldspar, and calcareous nannofossils.

Unit III was deposited by hemipelagic settling along with accumulation of volcanic ash during major volcanic eruptions. The stratigraphic position of Unit III is below the trench-wedge facies of Unit II. Its early Pleistocene-Miocene age and overall lithologic content are consistent with deposition in the Shikoku Basin. Similar deposits have been documented at Ocean Drilling Program Sites 808, 1173, and 1174 in the Muroto transect over $100 \mathrm{~km}$ to the westsouthwest along the Nankai Trough (Shipboard Scientific Party, 2001a, 2001b; Moore et al., 2001).

\section{Diagenesis}

Overall, diagenetic effects observed at this site correspond almost entirely to mechanical processes, an unsurprising result given that the maximum temperature in the deeper portions of Site C0006 is not expected to exceed $40^{\circ} \mathrm{C}$ (see "Physical properties"). Even allowing for uplift, the detrital feldspar and clay mineral assemblages at these temperatures are expected to provide reasonably faithful records of provenance information. Volcanic glass observed at this site is water-clear in transmitted light and shows no discernible evidence of alteration at the scale of smear slide observation.

Only minor evidence of chemical diagenesis could be detected at this site using macroscopic core observation and smear slides. Pyrite in the form of framboids, pyritized burrows, and small $(<1 \mathrm{~cm})$ nodules is distributed widely through the mudrocks in all of the units and is appreciated most fully in X-ray CT images.

Occurrences of ash cemented by calcite or dolomite were also encountered. Most samples of this material were discovered as pieces of relatively lithified rubble in the tops of cores (Table T6). Two possible in-place occurrences of this lithology are in Sections 316C0006F-12R-1, 7-32 cm, and 13R-2, 45-52 cm. A second less certain in-place occurrence is in Section 316-C0006F-20R-1, 10-12 cm. XRD analysis indicates that the nonash component of these rocks consists of either dolomite or calcite with minor amounts of clay, quartz, and feldspar. Measurements of resistivity and velocity in one sample (rubble collected from Section 316-C0006E-46X-1) indicate values far in excess of that observed for normal silty clay $\left(8 \mathrm{~cm}^{3}\right.$ cube; $3.0 \times 1.9 \times 3.3 \mathrm{k} \Omega ; \sim 5.1 \mathrm{~km} / \mathrm{s} P$ wave velocity; see "Physical properties"). Resisitivity logs (see the "Expedition 314 Site C0006" chapter) show thin intervals of extremely high values and associated low gamma ray intensity that may correspond to this lithology. Further clues about the distribution of authigenic carbonate come from the drillers who reported informally having encountered extremely hard but thin layers. In thin section the dolomite appears as microcrystalline cement in wellsorted, little-compacted, and very pure volcanic ash (Fig. F7C). Millimeter-scale laminations correspond to different compactional states of the ash particles.

A third minor instance of chemical diagenesis was observed in Section 316-C0006F-19R-1, $91 \mathrm{~cm}$ (dark gray mud of Unit III). A minute sand concentration (most likely an agglutinate test) was examined in smear slide and discovered to contain an abundance of 2-10 $\mu \mathrm{m}$ bladed crystals having low relief and extremely low birefringence (Fig. F10). These small crystals are very tentatively identified as the zeolite phillipsite.

\section{X-ray CT number}

X-ray CT images were used extensively by the science party for evaluation of sedimentological and structural features. Figure F11 shows the depth trends for CT number (averaged pixel intensity for a $1 \mathrm{~mm}^{2}$ area) determined for coherent pieces and tectonic breccia clasts of silty clay. CT number reflects the average sample density at the scale of the CT observation, a value that is affected by sample composition (mineral composition and density) and porosity (bulk density), although in these porous samples, it is largely dominated by porosity. Across Unit I through Subunit IIC, CT number increases with depth. CT number decreases gradually from 1450 to 1300 between lower Subunit IID and upper Unit III. The lowest value of 1300 in this section is shown at $480 \mathrm{~m} \mathrm{CSF}$, and CT number recovers to 1450 at $530 \mathrm{~m}$ CSF. This relatively low CT number zone is consistent with the lower mud-dominant part of the site. 


\section{Structural geology}

Various deformation structures were observed in cores and X-ray CT images from Holes C0006E and C0006F. Figure F12 summarizes the structural observations. All structural data are given as supplementary material (see C0006_STRUCT_DATA.XLS in folder 316_STRUCTURE in "Supplementary material").

\section{Bedding and fissility surface attitude and evolution with depth}

Among the 174 measurements of bedding surface attitudes obtained by visual inspection of cores, 126 were corrected for true magnetic north using paleomagnetic data. Thirty one measurements are relevant to lithologic Unit I (trench to slope sediments, between 0 and $27 \mathrm{~m} \mathrm{CSF}$ ). The remaining 95 measurements pertain to the accretionary prism sediments crossed between 27 and $600 \mathrm{~m}$ CSF. Of a total of 65 fissility measurements, 63 can be used with good reliability. All fissility measurements were obtained in the accretionary prism sediments at depths $>100$ m CSF (Fig. F12). Figure F12 shows a clear decrease of the dip angles of bedding surfaces and fissilities with increasing depth, from up to $75^{\circ}$ to $30^{\circ}$ or less. A similar change of bedding dip angle versus depth was also obtained from analysis of LWD data (see "Structural geology" in the "Expedition 314 Site C0006" chapter).

Most bedding surfaces in slope sediments strike north-south to northwest-southeast and dip westward (Fig. F13A). Strikes of bedding or fissility surfaces in accretionary prism sediments (below $27 \mathrm{~m}$ $\mathrm{CSF}$ ) are variable and no preferred direction is apparent (Fig. F13B, F13C).

\section{Deformation in lithologic Unit I}

Trench to slope transition sediments of lithologic Unit I are poorly consolidated. Between 15 and $35 \mathrm{~m}$ CSF, they are affected by normal faults striking north-south to northwest-southeast and dipping steeply (Fig. F14) with offsets $<10 \mathrm{~cm}$. Because of poor consolidation, fault surfaces could not be separated in order to allow examination of possible striations. Between 28 and $31 \mathrm{~m} \mathrm{CSF}$, which is slightly below the normal fault interval, the sediments are cut by two reverse faults showing very small offsets $(<1 \mathrm{~cm})$.

\section{Deformation structures within the fractured/brecciated zone}

Visual core description (VCD) and CT images allow us to distinguish a broad fractured/brecciated zone extending from 230 to $545 \mathrm{~m} \mathrm{CSF}$ in which fracture density and intensity is highly variable (Fig. F15).
This zone differs from the sections above or below with the following characteristics:

1. Coherent pieces of cores are short, usually not exceeding one section $(\sim 1.4 \mathrm{~m})$.

2. Cores are commonly strongly fractured.

3. Striated or polished planes are common.

4. The zone contains intervals of breccias that are unambiguously of tectonic origin.

By contrast, the sections above or below this fractured and brecciated interval are more coherent, less fractured, and generally do not include tectonic breccias. The transition between the fractured/ brecciated zone and the underlying section appears rather sharp.

\section{Minor faults}

Within the fractured/brecciated zone defined above, minor faults of various types can be observed on cores, as well as on CT images.

CT images were used to investigate the fault geometry and offsets that existed prior to whole-round sampling and cutting. Figure F16 shows a CT image of a fault displacing worm tubes with a normal offset of $\sim 1 \mathrm{~cm}$. Visually, this fault displays parallel lineations, and the faces of the fault are mated. That the worm tubes are displaced when the fault surfaces are mated strongly suggests that the fault is natural. Paradoxically, this normal fault strikes approximately perpendicular to the maximum principal horizontal stress $\left(\sigma_{H \max }\right)$ direction inferred from borehole breakouts (see "Structural geology" in the "Expedition 314 Site C0006" chapter).

Within the fractured/brecciated zone recognized above, dip angles of faults are scattered but clusters around $60^{\circ}$ tend to dominate (Fig. F12). Fault plane strikes do not show any preferred direction (Fig. F17). Minor faults are characterized by striated and/ or polished surfaces or by offset markers. The sense of displacement is given by the offset of markers or, most commonly, by steps borne by the surface. Of the 220 observed faults, normal faults are the most frequent $(42 \%)$, followed by reverse faults $(12 \%)$ and left-lateral $(10 \%)$ or right-lateral (10\%) faults. The remaining faults (26\%) have undetermined or ambiguous senses of displacement. Preliminary kinematic analysis of populations of normal faults, reverse faults, and strike-slip faults has not yielded consistent results, implying that fault-slip data sets are not homogeneous (Fig. F17). Additional sorting is clearly needed in order to define homogeneous subsets.

\section{Fractures without displacement}

The distinction between natural fractures and drilling-induced fractures is not easy at Site C0006. A 
fracture that can be followed across several "parted" ("biscuited") core segments and that spans a distance greater than the borehole diameter is likely a natural fracture. Indeed, propagation of a fracture along the core is likely to stop at parting surfaces. The presence of plumose structures on fracture surfaces also supports natural propagation. A convincing example of such a tectonic fracture is found in interval 316C0006F-18R-1, 70-125 cm. The surface of this fracture shows well-preserved plumose structures (Fig. F18) that clearly indicate a pure mode-I opening that initiated at some distance from the core and propagated approximately horizontally. Moreover, this fracture strikes parallel to the direction of $\sigma_{H \max }$ inferred on the basis of borehole breakouts in Expedition 314 (see "Structural geology" in the "Expedition 314 Site C0006" chapter); hence it is not drilling induced. However, when fractures are of small size (less than three times the core diameter) and lack plumose structures, there remains much ambiguity regarding the origin of the measured planes.

\section{Deformation bands}

Visually, deformation bands appear on cores as undulating bands that are darker than the host rock. Shear (tangential displacement) along deformation bands is established in several instances by offset markers. Deformation bands are visually observed in cores between 300 and $460 \mathrm{~m}$ CSF with a clear predominance between 300 and 405 m CSF (Fig. F12), which is within the fractured/brecciated zone mentioned above. Most deformation bands dip more steeply than $30^{\circ}$, and the sense of shear is reverse (Fig. F19). Figure F20 shows the equal-area projection of deformation bands for which paleomagnetic correction is reliable. These bands predominantly strike about northeast-southwest and dip either northwestward or southeastward, forming two sets with an apparent conjugate geometry. Each set was fitted by a mean plane, and the obtuse dihedral angle between the two mean planes is $\sim 97^{\circ}$. The bisecting plane of this angle strikes $\sim 48^{\circ}$ and is almost vertical. Given the reverse sense of slip observed along these deformation bands, this geometry suggests a shortening axis oriented horizontal along $138^{\circ}$. A similar direction of shortening was previously deduced from deformation bands in the Muroto transect in the Nankai accretionary prism (Ujiie et al., 2004).

Deformation bands appear as bright bands in CT images. The CT number for deformation bands is often 100 greater than that of the surrounding rock and likely reflects densification within the bands. A systematic search of CT images over the depth interval from 160 to 400 m CSF (Fig. F21) confirms the het- erogeneous density distribution of bands determined by visual inspection.

Combined VCD and CT image analyses indicate that deformation bands are concentrated between 240 and $400 \mathrm{~m}$ CSF. The lower density of deformation bands below $400 \mathrm{~m}$ CSF may also be explained by a lithologic change because deformation bands tend to be developed in mudstones which lack bioturbation. Below $400 \mathrm{~m} \mathrm{CSF}$, the sedimentary pile is dominated by bioturbated mudstone. Bioturbation may prevent deformation bands from forming, possibly because of a random reorganization of initially well aligned clay particles.

\section{Sediment-filled veins}

Sediment-filled veins (vein structures) are uncommon at Site C0006. The clearest examples were observed at six locations between 395 and 510 m CSF. Sediment-filled veins are planar or sigmoidal. One occurrence shows sediment-filled veins displaced in a reverse sense by deformation bands (Fig. F19C).

\section{Sand injection}

Sand injection cut by biscuiting boundaries associated with ESCS coring can be observed at $370.18 \mathrm{~m}$ CSF. Injection is either vertical (sand dike, Fig. F22) or horizontal (sand sill). Boundaries with the host rock are sharp and planar or irregular. The injected sand is medium to coarse grained, and is well sorted. It is homogeneous except for elongated wood fragments that can reach $1 \mathrm{~cm}$ in length. No internal structure can be recognized in the filling.

\section{Definition of zones of concentrated deformation within the fractured/ brecciated zone}

The distribution of structural elements in the fractured/brecciated zone is shown in Figure F23. Core and thin section observation and CT image analysis allow us to define several intervals within the fractured/brecciated zone that appear significantly more deformed than the background (and that could be interpreted as faults). Because the whole zone is affected by tectonic fracturing as well as by drillinginduced disturbance, the definition of deformed intervals was based on all possible observations and will be further tested by onshore studies. Key observations that, taken together, allow us to define these intervals are

1. The presence of fault rocks such as breccia or gouge;

2. The presence of strongly fractured intervals (by strongly fractured, we mean that the intact core segments, if any, have lengths smaller than the 
core diameter because of natural fracturing [biscuiting excluded]);

3. The presence of discontinuities of any type, such as abrupt changes in lithology, fracture, or deformation band intensity; and

4. A progressive change that leads to locally high density and/or preferred orientation of fabric elements, such as deformation bands and fractures, commonly associated with faults.

Based on these criteria, the following intervals appear as concentrated zones of deformation:

- 235-243 m CSF (Cores 316-C0006E-31X through $32 \mathrm{X})$,

- 277-297 m CSF (Core 316-C0006E-36X through the top of $38 \mathrm{X}$ ),

- 367.5-369.5 m CSF (Core 316-C0006E-45X),

- 433.75-440.00 m CSF (Cores 316-C0006F-5R through 6R), and

- 526-545 m CSF (Cores 316-C0006F-15R through 17R).

The 433.75-440.00 m CSF interval coincides with a biostratigraphic hiatus whose origin is still undetermined (see "Biostratigraphy").

\section{5-243 m CSF (Cores 316-C0006E-31X and $32 \mathrm{X}$ )}

On the basis of CT image measurements, linear density of deformation bands increases with depth from $210 \mathrm{~m}$ CSF to a maximum of 21 bands/m in Section 316-C0006E-32X-1 (Fig. F21). Linear density of deformation bands decreases abruptly in the middle of Section 316-C0006E-32X-2 and then remains low downhole through Section 316-C0006E-32X-5. Fracturing also progressively increases in intensity with depth through Core 316-C0006E-31X, displays maximum intensity in intervals 316-C0006E-32X-1 and $32 \mathrm{X}-2$, and decreases through Section 316-C0006E32X-5. Locally in Sections 316-C0006E-31X-5 through $32 \mathrm{X}-2$, finely fractured rocks are evident where fracture spacing is $<1 \mathrm{~cm}$ and the fractures display strong preferred orientations. On the basis of VCDs, these intervals are classified as highly fractured rocks.

A prominent fracture surface in Section 316-C0006E31X-5 (235.30 m CSF) juxtaposes two fractured units with contrasting CT numbers (Fig. F24). With a correction based on paleomagnetic data, the surface is oriented $043^{\circ}, 29^{\circ}$ southeast, which is approximately parallel to one of the preferred orientations of deformation bands with reverse sense of shear and thus is compatible with regional northwest-southeast contraction.

\section{7-297 m CSF (Core 316-C0006E-36X)}

Core $316-\mathrm{C} 0006 \mathrm{E}-35 \mathrm{X}$ is characterized by unbroken mudstone in which subhorizontal bedding and fissility are well preserved. At 277.39 m CSF (Section 316C0006E-36X-1, $6 \mathrm{~cm}$ ), a network of anastomosing fractures cuts the subhorizontal layering (Fig. F25A). Below this depth, fractured and brecciated mudstones are observed throughout Core 316-C0006E36X (Fig. F25B). The fracture sets are spaced as little as a few millimeters apart and have an anastomosing geometry, suggesting incipient brecciation (protobreccia). Brecciated fragments are centimeter to millimeter size with distinctly polished and slickenlined surfaces. Mudstone tends to be brecciated along the sets of inclined and subhorizontal surfaces, showing a foliated aspect. The abrupt occurrence of millimeterspaced anastomosing fracturing and brecciation across the top of Core 316-C0006E-36X constitutes a significant discontinuity that could correlate to a fault surface.

\section{5-369.5 m CSF (Core 316-C0006E-45X)}

Core 316-C0006E-44X and Sections 316-C0006E$45 \mathrm{X}-1$ through $45 \mathrm{X}-5,35 \mathrm{~cm}$, are dominated by fractured mudstones. Interval 316-C0006E-45X-5, $35 \mathrm{~cm}$, through $45 \mathrm{X}-6,71 \mathrm{~cm}$, is characterized by breccia, including centimeter- to millimeter-sized fragments that are ubiquitously polished and striated (Fig. F26A). At 369.18 m CSF (Section 316-C0006E-45X-6, $71 \mathrm{~cm}$ ), a subhorizontal surface parallel to bedding/ fissility separates the brecciated interval above from the coherent interval below (Fig. F26B). Below this depth, original layering of sands and mudstones are well preserved and sands locally intrude into mudstone (see above, sand injection), which in turn are cut by biscuiting boundaries. The change in deformation style from fractured mudstone to breccia with depth and the prominent boundary between breccia and unbroken sands and mudstone layers at $369.18 \mathrm{~m}$ CSF suggest the presence of a fault.

\subsection{5-440.00 m CSF (Cores 316-C0006F-5R and 6R)}

Following Cores 316-C0006F-3R and 4R, which consist of $\sim 4 \mathrm{~m}$ of highly fractured rock of unknown origin (tectonic, drilling-induced, or splitting-induced), Core 316-C0006F-5R includes coherent pieces of mudstones (interval 316-C0006F-5R-1, 0-73 cm) underlain by highly fractured mudstones nearly $2 \mathrm{~m}$ thick. Fragments have sizes $<1 \mathrm{~cm}$ and commonly show polished/striated surfaces. The presence in interval 316-C0006F-5R-CC, $4-23 \mathrm{~cm}$, of a piece of tectonic breccia (Fig. F27) is consistent with the presence of a major fault nearby. Core 316-C0006F-6R is 
similar to the above-lying Core 316-C0006F-5R. It consists of $2 \mathrm{~m}$ of highly fractured mudstones with $\sim 20 \mathrm{~cm}$ of tectonic breccia in the core catcher, confirming deductions from Core 316-C0006F-5R.

\section{6-545 m CSF (Cores 316-C0006F-15R through 17R)}

Section 316-C0006F-15R-3 shows a downhole increase in brecciation intensity. At $526.51 \mathrm{~m}$ CSF (Section 316-C0006F-15R-3, $48 \mathrm{~cm}$ ), breccia is replaced by microbreccia (most brecciated fragments are $<1 \mathrm{~mm}$ in size), which in turn changes to fault gouge at $526.65 \mathrm{~m} \mathrm{CSF}$ (Fig. F28A). The thickness of the gouge zone is $8 \mathrm{~cm}$. Careful observation of fault gouge both in core and thin section reveals that fault gouge is locally foliated, preserving composite planar fabric associated with shear (Fig. F28B). Below the gouge zone, breccia occurs again in Cores 316C0006F-16R (Fig. F28C) and 316-C0006F-17R. Core $316-\mathrm{C} 0006 \mathrm{~F}-18 \mathrm{R}$ is characterized by jointed mudstone with little or no evidence of brecciation.

\section{Deformation below the fractured/ brecciated zone}

Sediments found in the 545-603 m CSF interval, which consist of bioturbated hemipelagic mudstones (lithologic Unit III), are less fractured or brecciated than above $545 \mathrm{~m}$ CSF. Dip angles of fault planes are scattered between $20^{\circ}$ and $88^{\circ}$, but steep angles predominate (Fig. F12). No preferred orientation of fault plane directions can be recognized. Among these faults, normal faults predominate (Fig. F29).

\section{Discussion}

The five intervals described above appear more deformed than the surrounding cores. In particular, they all include tectonically brecciated intervals recognized either visually or by relying on CT images. These five intervals are interpreted as faults within the fractured/brecciated zone. Such interpretations remain hypothetical, partly because of the generally poor recovery near the considered intervals. Keeping in mind these uncertainties, it is then possible to propose correlations between these fault intervals and the reverse faults recognized on seismic lines passing nearby Holes C0006E and C0006F (Fig. F30; see Moore et al.).

\section{Conclusion}

Despite poor recovery and drilling- or splittinginduced disturbance, CT scan image analysis and visual examination of cores from Holes C0006E and C0006F allow us to define a broad fractured/ brecciated zone that includes at least five intervals of concentrated deformation. The presence of these five intervals shows that deformation is not evenly distributed along the whole fractured/brecciated zone but is localized along narrow zones corresponding to faults, as suggested by seismic reflection profiles. Because of poor recovery, it is impossible to propose a typical thickness of fault core and damaged zone for any of the five recognized faults.

\section{Biostratigraphy}

Four holes were drilled at Site C0006 into the toe of the Nankai accretionary prism during Expedition 316. Only one core each was retrieved in Holes C0006C and C0006D. Hole C0006E was cored from the seafloor to $406.97 \mathrm{~m}$ CSF through slope sediments and into the sediment inferred to have been the marginal trench wedge deposits. Hole C0006F was cored from 390 to $603 \mathrm{~m} \mathrm{CSF}$ in the lower part of the thrusted trench deposits into the upper part of Shikoku Basin sediments.

The biostratigraphy determined for Site C0006 is based on examination of calcareous nannofossils, radiolarians, and foraminifers from Holes C0006E and C0006F. In addition, a few samples from C0006F were analyzed for diatoms.

\section{Calcareous nannofossils}

Sediments recovered from Holes C0006E and C0006F are dominated by interbedded sand layers and volcanic ash layers in turbidite sequences (see "Lithology"), yielding few to rare and moderately to poorly preserved nannofossils in most samples from core catchers and within cores. This lack of nannofossils results in difficulties establishing a biostratigraphy. At least three difficult issues are merged: scarcity of nannofossils, poor preservation, and reworking.

A number of nannofossil samples were carefully selected from thin clay or particular ash layers within cores that contain relatively abundant and moderately preserved nannofossils (Tables T7, T8).

Problems due to poor preservation still exist. A case commonly seen in many samples is that only largesized nannofossils were preserved in sediments, whereas most small-sized species were lost. That is, the nannofossil assemblages found in sediments were changed by various processes, probably by dilution during turbidite flow, breakage by stress of deformation, and dissolution. These changes result in difficulties in finding and identifying event markers or in distinguishing them from species that are morphologically similar. Uncertain determination of species is indicated with a "?" in Tables T7 and T8. 
These uncertain data will be improved through shore-based study.

Reworking is very common throughout the sediment sequence recovered in Holes C0006E and C0006F, leading to confusion in the determination of a number of last occurrence (LO) events. To solve this problem, the co-occurrences of other age-diagnostic specimens or the nannofossil assemblages were examined in detail to make a reliable determination. For example, a few Reticulofenestra asanoi and Calcidiscus macintyrei were observed in the uppermost two cores of Hole C0006E (Table T7). Observations of nannofossil assemblages in this interval suggest that the assemblages are dominated by Gephyrocapsa carribeanica in the medium-sized Gephyrocapsa groups (Gephyrocapsa spp. medium I and II). The first occurrence (FO) of this species was estimated at $0.76 \mathrm{Ma}$ (Su, 1996). Therefore, the presence of $R$. asanoi and C. macintyrei in samples from these two cores was considered to be due to reworking.

A total of 17 nannofossil biostratigraphic events were recognized (Table T9). The presence of Emiliania huxleyi in Samples 316-C0006E-1H-CC and 2H-1, $34 \mathrm{~cm}$, was not determined with high confidence because of the small size of this species and poor preservation. However, correlation with geomagnetic data in the same hole suggests that these samples are younger than $0.29 \mathrm{Ma}$. Therefore, the transition (X) from Gephyrocapsa spp. (>3.5 $\mu \mathrm{m})$ to E. huxleyi was placed at $5.16 \mathrm{~m}$ CSF and the FO of E. huxleyi was placed at $5.19 \mathrm{~m} \mathrm{CSF}$, marking the bottom of Zone NN21 at this horizon. Common Pseudoemiliania lacunosa occurs in Sample 316-C0006E-3H-4, 79 cm, which was taken as its LO to mark the boundary between nannofossil Zones NN20 and NN19 (0.436 Ma), whereas its rare presence in samples above $15.22 \mathrm{~m}$ CSF is attributed to reworking.

The subdivision of Zone NN19 was difficult in Holes C0006E and C0006F, as nannofossil assemblages in most samples were significantly affected by the presence of large amounts of reworked fossils younger than Zone NN19, dilution by turbidite flow, and dissolution. Two separate intervals (from 73.35 to $85.54 \mathrm{~m}$ CSF and from $192.45 \mathrm{~m} \mathrm{CSF}$ to the bottom of the hole) in Hole C0006E contain R. asanoi $(\mathrm{LO}=0.9 \mathrm{Ma}$ and $\mathrm{FO}=1.078 \mathrm{Ma}$ ); however, the interval between 85.54 and $192.45 \mathrm{~m}$ CSF contains frequent Gephyrocapsa spp. large $(>5.5 \mu \mathrm{m})$ and common C. macintyrei with co-occurrence of Helicosphaera sellii, suggesting an earlier Zone NN19 age for this interval (Table T7; Fig. F31). Common medium-sized Gephyrocapsa lumina (a typical early Pleistocene species) are also present, indicating an early Pleistocene assemblage. The nannofossil data obtained during shipboard analyses support the assumption that the sedimentary se- quence within the occurrence range of $R$. asanoi contains at least one age reversal and possibly one or more minor or poorly defined age reversals. With this assumption, we propose a preliminary subdivision of Zone NN19 into three parts for Site C0006:

1. Normal Zone NN19 from 17.22 to 72.90 m CSF in Hole C0006E.

2. A possible repeated Zone NN19 in the middle part of Hole C0006E.

3. Normal Zone NN19 from 192.45 to $406.92 \mathrm{~m}$ CSF in Hole C0006E and from 396 to 496 m CSF in Hole C0006F (Table T7; Fig. F31).

Subsequently, a number of nannofossil events were determined for further subdivision of these parts of Zone NN19 (Table T9). Within the repeated part of Zone NN19, a short younger interval marked by the presence of $R$. asanoi in Sample 316-C0006E-24X-1, $96 \mathrm{~cm}$ (164.29 m CSF), is noted (Tables T7, T9). This sample was collected from Section 316-C0006E-24X (not a core catcher sample) and contains rare to frequent $R$. asanoi, which was confirmed by careful examination of several slides from the same sample. This sample contains a mix of younger and older species. Common to frequent Gephyrocapsa spp. $(\geq 4 \mu \mathrm{m})$ (reentrance $[\mathrm{RE}]=1.04 \mathrm{Ma}$ ) and common $C$. macintyrei (1.6 Ma) together with a few Gephyrocapsa spp. large ( $>5.5 \mu \mathrm{m} ; 1.617 \mathrm{Ma})$ were observed, implying a possible contact boundary of older and younger sediments, possibly due to faulting. This sample (164.29 m CSF) is located near a change in lithology. Therefore, we consider the occurrence of $R$. asanoi to be an indication of a short age reversal ( $>0.9$ to $<1.04 \mathrm{Ma}$ ) in the repeated Zone NN19 sequence in Hole C0006E. At the bottom of Hole C0006E, the RE of Gephyrocapsa spp. $(\geq 4 \mu \mathrm{m})$ at $391 \mathrm{~m}$ CSF is comparable to the RE of Gephyrocapsa spp. $(\geq 4 \mu \mathrm{m})$ at $396 \mathrm{~m} \mathrm{CSF}$ in Hole C0006F, providing consistent evidence from both holes. Four events, including the RE of Gephyrocapsa spp. ( $\geq 4$ $\mu \mathrm{m})$, were available for subdivision of Zone NN19 sediments in Hole C0006F (Table T9).

Nannofossils below $434.71 \mathrm{~m}$ CSF were very poorly preserved, and a number of samples were barren of nannofossils (Table T8). Most nannofossil records were obtained from carefully selected thin clay intervals, ash layers, or ash pods within cores. These records allow identification of event markers and subdivision of the lower part of Hole C0006F into a sequence from middle Pliocene Zone NN16 to upper Miocene Zone NN12 (Table T9). The bottom of the repeated Zone NN19 interval, marked by the bottom of the first consistent occurrence (FCO) of Gephyrocapsa spp., was truncated by a number of late Pliocene events: the LOs of Discoaster brouweri (marker of Zone NN18), Discoaster pentaradiatus (marker of Zone 
NN17), and Discoaster surculus (marker of Zone NN16) at $459.01 \mathrm{~m}$ CSF (Tables T8, T9), indicating the absence of the lower part of lower Pleistocene Zone NN19, upper Pliocene Zone NN18, and Zone NN17. A truncation in the same time interval was also observed at Site C0004 (see "Biostratigraphy" in the "Expedition 316 Site C0004" chapter); however, we are unable to explain the possible correlation at the present time. The sediment sequence from 459.01 to $485.88 \mathrm{~m}$ CSF was assigned to middle Pliocene calcareous nannofossil Zone NN16 based on the co-occurrence of $D$. surculus (marker of top of Zone NN16) and D. tamalis, as well as on the absence of Reticulofenestra pseudoumbilicus ( $>7 \mu \mathrm{m}$ ) (marker of top of Zones NN15-NN14) (Table T8). The recognition of the LO of Sphenolithus spp. at $476.98 \mathrm{~m} \mathrm{CSF}$ provides subdivision of this zone. The interval from 487.67 to $505.42 \mathrm{~m}$ CSF was assigned to lower Pliocene Zones NN15-NN13 with its top marked by the LO of $R$. pseudoumbilicus $(>7 \mu \mathrm{m})$ and its bottom marked by the FO of Ceratolithus rugosus (marker of boundary of Zone NN13/NN12). Zones NN15-NN13 could not be further subdivided in Hole C0006F because of the trace or sporadic presence of Discoaster asymmetricus (marker of base of Zones NN15-NN14) in Hole C0006F. The absence of Discoaster quinqueramus (marker of top of Zone NN11; LO = 5.59 Ma) from the whole sequence of Hole C0006F suggests that the interval from $507.53 \mathrm{~m}$ CSF to the bottom of the hole is within Zone NN12 and younger than $5.59 \mathrm{Ma}$ (Table T8). The lowest occurrence of Ceratolithus acutus at $580 \mathrm{~m} \mathrm{CSF}(\mathrm{FO}=5.32 \mathrm{Ma})$ was the only possible event marker identified for the long interval of Zone NN12.

\section{Other microfossil groups}

All core catcher samples were processed for radiolarian analysis, but most of them were barren. Sample 316C0006E-1H-CC revealed a poorly preserved assemblage with apparent breakage. A few undiagnostic or nonidentifiable diatom frustules and fragments were found within the section to Core 316-C0006E-13H.

Planktonic foraminifers occur sporadically to Core 316-C0006E-11H (71.38 m CSF). However, abundant Pulleniata finalis were found in a horizon in Section 316-C0006F-6R-1, $100 \mathrm{~cm}$ (439 m CSF), indicating an age younger than $2.06 \mathrm{Ma}$.

A few discrete horizons within cores were also sampled for diatoms and radiolarians, but those that were not barren revealed only very rare broken specimens.

\section{Summary and correlation to faults}

Based on the nannofossil record at Site C0006, 17 nannofossil biostratigraphic events were recognized and assigned an age of upper Miocene Zone NN12 to Pleistocene. The uppermost part of Zone NN21 might include a thin sediment layer of Holocene age. This is undeterminable based on nannofossil biostratigraphy. Plots of age versus depth in Holes C0006E and C0006F are combined with magnetostratigraphic results in Figure F31.

An age repetition interval was identified within Zone NN19; the occurrence range of $R$. asanoi in Zone NN19 may contain one or more repetitions within the sequence from 85.54 to $185.39 \mathrm{~m}$ CSF in Hole C0006E. There is also some inconclusive evidence for either a hiatus or an erosive event within this interval; however, shipboard data were insufficient to clarify nannofossil stratigraphy at this level of detail. This repetition is probably caused by faulting, in agreement with the lithologic Subunit IIB/IIC boundary. It is also possible that the "older" age assignment was affected by the presence of a large number of reworked older fossils and a lack of sufficient nannofossil data because of poor preservation. This will be improved through postcruise study. A short time gap of $\sim 0.17$ m.y. was found between 434.71 and $439.50 \mathrm{~m}$ CSF (Table T8; Fig. F31).

The bottom of repeated Zone NN19 sediments is truncated by middle Pliocene Zone NN16 sediments at $449.70 \mathrm{~m}$ CSF in Hole C0006F, indicating a time gap of $\sim 1$ m.y. Abundant planktonic foraminifers $P$. finalis $(<2.06 \mathrm{Ma})$ found in Sample 316-C0006F-6R-1, $100 \mathrm{~cm}$ (439 $\mathrm{m} \mathrm{CSF})$, provide evidence for this age estimate. The time gap in Hole C0006F is consistent with the lithologic Unit II/III boundary. Unit III sediments were subdivided into middle-lower Pliocene Zone NN16, Zones NN15-NN13, and upper Miocene-lower Pliocene Zone NN12.

Results from seismic and structural studies at Site C0006 suggest several faults below $230 \mathrm{~m}$ CSF (see "Structural geology"). More detailed examination of nannofossil records from samples within these fault zones reveals poor preservation, indicating mechanical reworking and/or chemical degradation. For example, more nannofossil debris was observed in Samples 316-C0006E-45X-CC, 316-C0006F-6R-CC, and $17 \mathrm{R}-\mathrm{CC}$, whereas nannofossils have overgrown features in Samples 316-C0006F-31X-CC and 36X-CC (see the five zones of deformation in "Structural geology"). The short time gap between 434.71 and 439.50 m CSF (Table T8; Fig. F31) can be correlated to the possible fourth fault zone (see "Structural geology"). In addition, a difference between the upper and lower parts of the repeated interval of $R$. asanoi (192.48-434.71 m CSF; $>0.9$ to $<1.078 \mathrm{Ma}$ ) was noted: nannofossils are moderately preserved above $358 \mathrm{~m} \mathrm{CSF}$, whereas they are poorly preserved and sediments contained more common reworked nannofossils below that depth (Tables T7, T8). 
Furthermore, two very long sediment intervals covering such a short time span seem unlikely to be solely due to high sedimentation rates: the interval of $R$. asanoi (0.9-1.078 Ma) between 192.45 and $434.71 \mathrm{~m}$ CSF and the interval of Zone NN12 between 505.42 and $591.45 \mathrm{~m}$ CSF. Considering faults observed in these two intervals, it is reasonable to infer that their thickness might be partially caused by duplication due to thrust faulting.

\section{Paleomagnetism}

We made pass-through magnetometer measurements on all split-core archive sections at $5 \mathrm{~cm}$ intervals. In order to isolate characteristic remanent magnetization (ChRM), we subjected the cores to alternatingfield (AF) demagnetization. The archive-half cores were typically demagnetized to $40 \mathrm{mT}$. Before measurement data were uploaded to the J-CORES database, we excluded the top and bottom $\sim 15 \mathrm{~cm}$ to avoid end-core edge effects (response of the magnetometer's pickup coils is $\sim 20 \mathrm{~cm}$ ) as well as those for voids caused by whole-round sampling. In order to test the archive-half core data and identify magnetic carriers, we demagnetized a total of 102 discrete samples using both $\mathrm{AF}$ and thermal techniques.

\section{Natural remanent magnetization and magnetic susceptibility}

Paleomagnetic data obtained at Site C0006 during Expedition 316 exhibit significant variations in demagnetization behavior among various recovered lithologies. Drilling-induced remagnetization exists in the recovered cores (Figs. F32, F33, F34), but it had less effect compared with those in Hole C0004C sediments. Interestingly, drilling-induced remagnetization in a few cores is of opposite polarity (see Figs. F32, F33B); perhaps a different type of core barrel was used to core these sediments. In almost all cases, we were able to remove drilling-induced remagnetization with 20-30 mT AF demagnetization and to isolate ChRM direction using higher fields.

The most significant variations in natural remanent magnetization (NRM) intensity and susceptibility for whole cores from Site C0006 are well correlated with lithology. Paleomagnetic measurements indicate that mudstones in Unit III have the lowest NRM intensity (averaging $\sim 0.1 \mathrm{~mA} / \mathrm{m}$ ) compared to those in turbidite Unit II $(\sim 12 \mathrm{~mA} / \mathrm{m})$ and nannofossilbearing mud and sand in Unit I $(\sim 2 \mathrm{~mA} / \mathrm{m})$. Variations in magnetic susceptibility generally correlate with variations in NRM intensity (Fig. F32). Magnetic susceptibility values are generally $\sim 19 \times 10^{-3} \mathrm{SI}$ for sediments in Unit I, $>200 \times 10^{-3}$ SI for Unit II, and
$12 \times 10^{-3}$ SI for Unit III. A few discrete peaks of higher NRM and susceptibility values appear in some depth intervals in Units I and II (e.g., around 18, 27, 161, 231, and $326 \mathrm{~m}$ CSF; see Fig. F32) and visibly correlate with the presence of volcanic ash in these regions (see "Lithology").

\section{Paleomagnetic stability tests and core orientation}

Remanent magnetization of discrete samples was investigated using stepwise AF or thermal demagnetization (Fig. F33). In most cases, the steep downward component of magnetization imparted by the coring process is easily removed by AF demagnetization. Thermal demagnetization also successfully removed this drilling-induced component (Fig. F34). Most samples show unblocking temperatures between $200^{\circ}$ and $400^{\circ} \mathrm{C}$, indicating that titanomagnetites are likely the main magnetic carriers in these samples. A histogram of inclinations isolated from discrete samples is shown in Figure F35. Inclinations from archive-half core pieces at $<100 \mathrm{~m}$ CSF are concentrated at approximately $\pm 45^{\circ}$ (Fig. F32), similar to the expected dipole inclination at the site $\left(52^{\circ}\right)$. A pronounced shallowing of inclinations is evident in the interval from $\sim 120$ to $380 \mathrm{~m} \mathrm{CSF}$, where inclination values are more typically shallower than $30^{\circ}$. This interval corresponds to the observed zones of faulting and fracturing (see "Structural geology"), suggesting that inclination values may have been affected by faulting and tilting. Results from discrete sample demagnetization also provide an opportunity to evaluate the accuracy of archive-half core remanence data that are used (in combination with discrete sample results) to reorient core pieces to a common geographic framework. This paleomagnetic core reorientation method has been successfully used for both continental and oceanic outcrops (e.g., Fuller, 1969; Kodama, 1984; Shibuya et al., 1991). Assuming the direction of stable remanent magnetization (either viscous remanent magnetization or primary magnetization) with respect to a common reference line that is scribed the length of the core represents the expected magnetic direction at the site, the orientation of paleomagnetic ChRM, which specifies the rotation of the core relative to the geographic coordinates, is then used to restore the core azimuth. For intervals of particular interest for structural geology at Site C0006, we used either the stable ChRM isolated from progressive demagnetization of discrete samples and small homogeneous segments (that contain structural features) or an average declination from 3-4 consecutive measuring intervals with the same inclination sign from archive-half core data. The combined data sets suggest that defor- 
mation bands in cored units generally strike southwest and dip northwest or southeast (See "Structural geology").

\section{Magnetostratigraphy}

We used ChRM inclinations from both pass-through and discrete measurements to define magnetic polarity sequences for Site C0006. As at Site C0004, magnetic polarity sequences at Site C0006 could not be completed because of incomplete recovery and wholeround sampling of archive-half sections. Faulting also affects this site and complicates magnetostratigraphy. Nevertheless, a few magnetic reversals discerned on the basis of changes in sign of inclinations can be identified, which constitute partial magnetostratigraphic records at Site C0006. Biostratigraphic samples between 5 and $10 \mathrm{~m}$ CSF in Hole C0006D have been assigned ages of $\sim 0.43 \mathrm{Ma}$. Thus, the observed predominantly negative inclination in this interval suggests that these sediments were deposited within the Emperor event (0.42 Ma), a short reversed polarity event within the upper part of the Brunhes normal chron (Gradstein et al., 2004). This event is likely recorded in Holes C0006C and C0006E, each $\sim 2.5 \mathrm{~m}$ from Hole C0006D, and at Site C0004 ( $20 \mathrm{~km}$ northwest of Site C0006). If confirmed by further shore-based study, this record could serve as a chronostratigraphic marker to correlate sedimentary layers in the Nankai Trough region.

On the basis of shipboard micropaleontological data, the uppermost $80 \mathrm{~m}$ of sediment in Hole C0006E has an age in the range of $0.8-1.1 \mathrm{Ma}$. The Brunhes/ Matuyama Chron boundary $(0.78 \mathrm{Ma})$ is placed at $32.75 \mathrm{~m} \mathrm{CSF}$ as magnetic inclination at this depth changes polarity from normal to reversed (Fig. F36). This match is definite because the Matuyama is the only reversed chron of this particular age. Between 145 and $192 \mathrm{~m} \mathrm{CSF}$, cores have been assigned to ages ranging from 1.6 to $1.67 \mathrm{Ma}$ (see "Biostratigraphy"). Therefore, the shift in polarity from reversed to normal at $160 \mathrm{~m}$ CSF would correspond to the onset of the Gilsa Subchron (1.68 Ma), and the upper part of Hole C0006E contains only a partial record of the Matuyama Chron and no record of the Jaramillo Subchron (0.99-1.07 Ma).

Biostratigraphic data suggest that sediments between 200 and $410 \mathrm{~m}$ CSF may be $0.8-1.1 \mathrm{Ma}$ in age. This information suggests that the relatively well defined record of a reversed interval between 250 and $345 \mathrm{~m}$ CSF and the shift in polarity from reversed to normal at $\sim 345 \mathrm{~m}$ CSF represent the upper part of the Matuyama Chron and the onset of the Jaramillo normal polarity subchron and infer a relatively rapid sediment accumulation rate $(\sim 180 \mathrm{~m} / \mathrm{m} . \mathrm{y}$.) for the early Pleistocene in Holes C0006E and C0006F. Alter- natively, the thickness of the strata could also be due to thrust faulting in the region.

\section{Inorganic geochemistry}

The main objectives of the geochemical program at Site C0006 are to

- Characterize in situ biogeochemical reactions;

- Constrain in situ inorganic diagenetic reactions with depth;

- Identify potential deep sourced fluids within fault zones and other permeable horizons, as well as fluid-sediment reactions at the source; and

- Constrain the subsurface hydrology, including fluid flow pathways and possible transport mechanisms.

A total of 71 whole-round samples were collected for interstitial water analyses at Site C0006 (2 samples from Hole C0006C, 2 from Hole C0006D, 46 from Hole C0006E, and 21 from Hole C0006F). Wholeround lengths ranged from 10 to $42 \mathrm{~cm}$ with larger subsamples collected from cores recovered deeper within the hole where the sediments were more consolidated. There was no seafloor camera or ROV deployed at this site (see "Operations"), thus the mudline was targeted blindly. The first two holes failed to target the mudline, and therefore the exact depths of the four samples collected in Holes C0006C and C0006D are unknown. Based on sulfate values of these samples (Table T10), Core 316-C0006C-1H likely overpenetrated the sediment/water interface by $>10 \mathrm{~m}$ and Core 316-C0006D-1H likely missed the mudline by $\sim 8 \mathrm{~m}$. The mudline was successfully recovered in Hole C0006E.

Samples were collected at a spatial resolution of two per core in the uppermost $30 \mathrm{~m}$ in Hole C0006E to define the sulfate-methane transition (SMT) and to identify and quantify the anaerobic oxidation of methane (AOM) magnitude at this site, as well as for future geochemical and microbiological studies. Below Core 316-C0006E-3H, one sample was taken per core when recovery was sufficient. The geochemical objectives below the SMT in Holes C0006E and C0006F were to identify the main in situ diagenetic reactions in the sediment section and to identify any exotic/deeply sourced fluids along the fault zones. This was done through analysis of dissolved elements that reflect inorganic fluid-rock reactions or microbially mediated reactions. Elemental concentrations and $\delta^{18} \mathrm{O}$ isotope ratios are reported in Tables T10, T11, T12, T13, and T14 and plotted as a function of depth in Figures F37, F38, F39, F40, F41, F42, and F43. Because of the brecciated nature of some of the sedimentary material in Holes C0006E and 
C0006F (see "Structural geology"), some cores were extremely difficult to clean prior to processing. This is observed in elevated $\mathrm{SO}_{4}$ concentrations in Table T12, which show that a significant number of interstitial water samples were contaminated with surface seawater during drilling operations. All of the contaminated samples were collected below the SMT where in situ $\mathrm{SO}_{4}$ is expected to be zero. These samples were corrected for drill water contamination based on measured $\mathrm{SO}_{4}$ concentrations using the procedure and equations outlined in the "Inorganic geochemistry" section of the "Expedition 316 methods" chapter. Uncorrected concentrations of all of the elements analyzed are presented in Tables T12, T13, and T14, and corrected values are presented in Tables T10 and T11. Only corrected values are presented in the figures.

\section{Salinity, chloride, and sodium}

Pore fluid salinity varies from 34.4 at $1.3 \mathrm{~m}$ CSF to 29.50 at $571.2 \mathrm{~m}$ CSF (Fig. F37). Salinity at $571.3 \mathrm{~m}$ CSF (near the base of the hole) is $\sim 16 \%$ less than modern seawater value. The pore fluid salinity profile can be divided into two zones. (1) The first zone extends from the seafloor to the base of Subunit IIA and is characterized by a steady decrease from nearseawater value to 32.67 at the base of Unit I followed by an increase to 33.66 at $\sim 100 \mathrm{~m}$ CSF (Fig. F37A). (2) Below this depth pore fluid salinity decreases with minor variations to 31.83 at $400 \mathrm{~m}$ CSF (base of Subunit IIC). From $\sim 400 \mathrm{~m}$ CSF to TD, salinity continues to decrease but is more variable. The salinity decrease in the upper $\sim 20 \mathrm{~m}$ of the sediment section reflects active sulfate reduction and subsequent precipitation of authigenic carbonates consuming dissolved $\mathrm{SO}_{4}, \mathrm{Ca}$, and $\mathrm{Mg}$ within this interval (Fig. F38A, F38C, F38D). The drop in salinity at the top of Subunit IIB at $76.4 \mathrm{~m}$ CSF coincides with sharp minima in both $\mathrm{Cl}$ and $\mathrm{Na}$. The decrease in salinity from $\sim 400 \mathrm{~m}$ CSF to $\sim 603 \mathrm{~m}$ CSF (TD) coincides with decreasing $\mathrm{Cl}, \mathrm{Na}, \mathrm{K}, \mathrm{Rb}$, and $\mathrm{Mg}$.

Pore fluid chloride varies, ranging from 518 to $571 \mathrm{mM}$, and the profile can be divided into three distinct zones:

1. The first zone extends from the sediment/water interface to $100.1 \mathrm{~m} \mathrm{CSF}$. Cl in this zone initially decreases from 562 to $558 \mathrm{mM}$ at 1.3 to $12.2 \mathrm{~m}$ CSF and then increases to $571 \mathrm{mM}(\sim 2.1 \%$ greater than modern seawater value) at $100.1 \mathrm{~m}$ CSF. Superimposed on this increase is a sharp decrease in $\mathrm{Cl}$ at $76.4 \mathrm{~m} \mathrm{CSF}$, coincident with a sharp decrease in Na (Fig. F37B, F37C).

2. The second zone of the $\mathrm{Cl}$ profile extends from 100.1 to $534.2 \mathrm{~m} \mathrm{CSF}$ and is characterized by steadily decreasing $\mathrm{Cl}$ with local minor varia- tions (Fig. F37B). In this zone, a $\mathrm{Cl}$ minimum of $534 \mathrm{mM}$ at $292.0 \mathrm{~m} \mathrm{CSF}$ coincides with a $\mathrm{Na}$ minimum. A Cl peak of $562 \mathrm{mM}$ at $534.2 \mathrm{~m} \mathrm{CSF}$ is coincident with a fault zone (see "Structural geology").

3. The third zone extends from $534 \mathrm{~m}$ CSF to the base of the hole at $590.2 \mathrm{~m} \mathrm{CSF}$ and is characterized by steadily decreasing $\mathrm{Cl}$ to $\sim 7 \%$ less than modern seawater value.

The slow increase in $\mathrm{Cl}$ from 12.2 to $100.1 \mathrm{~m} \mathrm{CSF}$ may be the result of hydrous silicate formation during volcanic ash alteration or evidence of active gas hydrate formation in the upper sediment column. This slight $\mathrm{Cl}$ increase could also be a manifestation of trapped interglacial seawater, which would suggest that sufficient time has not yet passed for the signal to diffuse. During core recovery, gas hydrates dissociate and release freshwater into the pore spaces, thus diluting pore fluid $\mathrm{Cl}$. Two negative excursions in the $\mathrm{Cl}$ profile at 77 and $292 \mathrm{~m} \mathrm{CSF}$, coincident with excursions in salinity, clearly indicate gas hydrate dissociation during core recovery, with $\mathrm{Cl}$ values in these horizons being $\sim 6 \%$ and $5 \%$ of seawater value, respectively.

The Na profile mimics the $\mathrm{Cl}$ profile and increases to $\sim 300 \mathrm{~m}$ CSF, including a local minimum of $463 \mathrm{mM}$ (Fig. F37C) at $77 \mathrm{~m} \mathrm{CSF}$. Another local Na minimum of $463 \mathrm{mM}$ (Fig. F37C) at $292 \mathrm{~m} \mathrm{CSF}$ is coincident with a $\mathrm{Cl}$ minimum. Below $\sim 300 \mathrm{~m}$ CSF, Na decreases to TD with minor local minima and maxima. Two $\mathrm{Na}$ minima at 77 and $292 \mathrm{~m}$ CSF probably reflect localized gas hydrate dissociation during core recovery, which is also corroborated by the constant $\mathrm{Na} / \mathrm{Cl}$ ratio within these intervals (Fig. F37D). The general decrease in $\mathrm{Na}$ from $\sim 300 \mathrm{~m}$ CSF to TD also mimics the $\mathrm{Cl}$ profile (Fig. F37D).

\section{Pore fluid constituents controlled by microbially mediated reactions}

\section{Sulfate and alkalinity}

Sulfate decreases linearly from $25.2 \mathrm{mM}$ at $1.3 \mathrm{~m} \mathrm{CSF}$ to $2.14 \mathrm{mM}$ at $7.9 \mathrm{~m} \mathrm{CSF}$ (Fig. F38A) and is completely depleted by 12.2 m CSF. A concomitant increase in headspace methane concentration at $\sim 8 \mathrm{~m}$ CSF (see "Organic geochemistry") constrains the SMT to $\sim 8-12$ m CSF (Fig. F38F). The SMT depth is shallower at this site than at Site C0004 upslope, where the SMT is located at 16-20 m CSF. The shallower SMT at Site C0006 could be the manifestation of a higher methane flux or more intense sulfate reduction rates. Between the SMT and $~ 534$ m CSF, sulfate remains depleted with occasional peaks reflecting drilling-induced contamination (Table T12). Results for samples from the sulfate depletion zone were cor- 
rected for drilling contamination based on measured $\mathrm{SO}_{4}$ concentrations and are presented in Tables T10 and T11. All of these samples were highly brecciated. Below $\sim 534 \mathrm{~m} \mathrm{CSF}$, dissolved $\mathrm{SO}_{4}$ increases downhole (Fig. F38A). These units were highly consolidated with the exception of Core 316-C0006F-16R (534.2 $\mathrm{m} \mathrm{CSF}$ ), which was brecciated and from a fault zone. Thus, the outside of the interstitial water whole rounds were easy to clean, which would suggest the increase in sulfate values at the base of the hole reflects detectable in situ pore fluid sulfate. However, methane values remain elevated within this interval (see "Organic geochemistry") and alkalinity remains constant, suggesting the increase reflects sampling artifacts associated with drill water contamination. To be conservative, $\mathrm{SO}_{4}$ values of the deepest six samples were not used to correct pore fluid chemical data for drill water contamination.

Pore fluid alkalinity increases rapidly in Unit I and reaches a maximum of $25.8 \mathrm{mM}$ at $7.9 \mathrm{~m} \mathrm{CSF}$, concomitant with an increase in headspace methane (see "Organic geochemistry") and the SMT at this site. Alkalinity at the SMT is less than expected for sulfate reduction/organic matter degradation and AOM, suggesting active precipitation of authigenic carbonates near the depth of the SMT. This explanation is supported by decreases in $\mathrm{Ca}, \mathrm{Mg}$, and $\mathrm{Mn}$ in this depth interval (Figs. F38C, F38D, F39D). Below the SMT, alkalinity decreases to $3.3 \mathrm{mM}$ at $590.2 \mathrm{~m}$ CSF.

\section{Ammonium, phosphate, bromide, and manganese}

Ammonium monotonically increases through Unit I and Subunit IIA (Fig. F39A). Below this depth, ammonium continues to increase at a slower rate to the middle of Subunit IIB. The ammonium maximum of $6098 \mu \mathrm{M}$ occurs at $122 \mathrm{~m} \mathrm{CSF}$, below which concentration gradually decreases in Subunit IIC. The concentration gradient steepens in Subunit IID and Unit III, decreasing to $656 \mu \mathrm{M}$ by $590.2 \mathrm{~m}$ CSF. The steady ammonium increase in the upper $\sim 72 \mathrm{~m} \mathrm{CSF}$ indicates production by microbially mediated decomposition of organic matter fueled by sulfate reduction above the SMT. Ammonium remains elevated below the SMT because of a combination of ongoing organic matter degradation and high burial rates.

Phosphate increases rapidly in the upper sediment section, reaching a maximum of $89 \mu \mathrm{M}$ at $17.4 \mathrm{~m}$ CSF. Below this depth, phosphate decreases until $\sim 100 \mathrm{~m} \mathrm{CSF}$, below which it is close to detection limit to $593.8 \mathrm{~m}$ CSF. The increase in phosphate in the upper $17 \mathrm{~m}$ reflects active organic matter decomposition in the active sulfate reduction zone. Unlike dissolved $\mathrm{NH}_{4}, \mathrm{PO}_{4}$ decreases relatively sharply be- low the maximum at $17.4 \mathrm{~m} \mathrm{CSF}$, indicating that phosphate is controlled by mineral precipitation reactions. Thus, phosphate is likely controlled by apatite solubility, as authigenic apatite is the major sink for dissolved phosphate.

The dissolved bromide profile generally mimics the $\mathrm{NH}_{4}$ profile. $\mathrm{Br}$ increases from $0.86 \mathrm{mM}$ at $1.3 \mathrm{~m} \mathrm{CSF}$ to $1.06 \mathrm{mM}$ at $62.5 \mathrm{~m} \mathrm{CSF}$ and then remains relatively constant to the middle of Subunit IIC, below which it decreases gradually to $590.2 \mathrm{~m} \mathrm{CSF}(\mathrm{Br}=$ $0.86 \mathrm{mM})$. Bromide in marine interstitial water is sensitive to organic matter diagenesis, with concentration higher than seawater value reflecting marine organic matter decomposition. Terrestrial organic matter degradation does not contribute much $\mathrm{Br}$ to the pore fluids. The $\mathrm{Br}$ profile at this site reflects a mixture between marine and terrestrial organic matter degradation, but the relatively low $\mathrm{Br}$ indicates that the labile organic matter is predominantly terrestrial in origin. $\mathrm{Br}$ at Site C0006 is lower than at Site C0004, reflecting higher rates of terrigenous sedimentation at this site.

Manganese concentrations are above seawater value in the upper $4 \mathrm{~m}$ of the sediment column, reflecting $\mathrm{MnO}_{2}$ reduction during microbially mediated organic matter degradation. Manganese reaches depletion in the active sulfate reduction zone and at the SMT, likely due to precipitation of authigenic rhodochrosite at the alkalinity maximum. Manganese then increases slightly below this depth to an average of $\sim 4.5 \mu \mathrm{M}$ and remains relatively constant with depth to Subunit IID. The slightly elevated dissolved Mn from 17.4 to $406.0 \mathrm{~m}$ CSF likely reflects ongoing microbially mediated organic matter diagenesis using Mn oxyhydroxides as terminal electron acceptors. Manganese increases and is more variable in Unit III, possibly reflecting a different sediment source with a higher $\mathrm{MnO}_{2}$ and $\mathrm{Mn}$ hydroxide content.

\section{Major cations ( $\mathrm{Ca}, \mathrm{Mg}$, and $\mathrm{K}$ )}

Calcium decreases from $8.76 \mathrm{mM}$ at $1.3 \mathrm{~m}$ CSF to $3.97 \mathrm{mM}$ at $17.4 \mathrm{~m} \mathrm{CSF}$ (Fig. F38C). The Ca minimum is $\sim 7 \mathrm{~m}$ below the alkalinity maximum and the SMT. Magnesium rapidly decreases in the same depth range interval. Dissolved $\mathrm{Mg}$ decreases from $47.5 \mathrm{mM}$ at $1.3 \mathrm{~m}$ CSF to $33.8 \mathrm{mM}$ at $17.4 \mathrm{~m} \mathrm{CSF}$ (Fig. F38D). This decrease is $\sim 3$ times greater than that of $\mathrm{Ca}$ values, suggesting precipitation of $\mathrm{Mg}$ and $\mathrm{Ca}$ in authigenic carbonates, as well as the exchange of $\mathrm{Mg}$ to clay minerals formed by ash alteration. Below this depth, the $\mathrm{Ca}$ and $\mathrm{Mg}$ profiles are mirror images. From 17.4 to $448.5 \mathrm{~m}$ CSF, Ca steadily increases to $10.75 \mathrm{mM}$, below which the slope of the profile changes. Ca reaches $17.96 \mathrm{mM}$ at the base of the hole (Fig. F38C). Below the SMT, Mg continues to 
steadily decrease from $17.4 \mathrm{~m}$ CSF to $13.85 \mathrm{mM}$ at the bottom of the hole (Fig. F38D).

A significant amount of ash and up to $20 \%$ feldspar were identified in the sediment section drilled at Site C0006 (see "Lithology"). Concentrations of both of these components are highest in Subunit IIC. Alteration of the ash and feldspars could contribute to the increase in $\mathrm{Ca}$ (feldspar weathering) and decrease in $\mathrm{Mg}$ (ash alteration) from the SMT to the base of Subunit IID. In Unit III, Ca increases rapidly to $17.96 \mathrm{mM}$ ( 1.7 times seawater value) at the base of the hole, whereas $\mathrm{Mg}$ remains relatively constant. The increase in $\mathrm{Ca}$ in this depth interval could be the result of diffusive communication with a compositionally different fluid below the base of Hole C0006F or it could reflect more mature diagenetic reactions with depth.

Potassium decreases overall with depth. In the uppermost $17.4 \mathrm{~m}$, this decrease is more rapid than below, declining from $11.8 \mathrm{mM}$ at $1.3 \mathrm{~m}$ CSF to $10.4 \mathrm{mM}$ at $17.0 \mathrm{~m}$ CSF (Fig. F40E). $\mathrm{K}$ is likely higher than seawater value as a result of pressure changes that occur during core recovery or ion exchange with $\mathrm{NH}_{4}$ on clay minerals. Below this depth, $\mathrm{K}$ continues to decrease to $6.6 \mathrm{mM}$ in the middle of Subunit IID at 405.0 m CSF. From 405.0 m CSF to the base of Hole C0006F, K decreases more rapidly, reaching $3.2 \mathrm{mM}$ at $571.3 \mathrm{~m}$ CSF $(\sim 70 \%$ less than modern seawater value). The general decline in pore fluid potassium below the SMT is likely the result of in situ formation of zeolites during alteration of volcanic ash and feldspars. Authigenic zeolites, possibly phillipsite, were recognized in smear slides from selected intervals in Unit II (see "Lithology"). The rapid K decline in Unit III may reflect more mature diagenesis of volcanic ash and feldspars due to the greater age of the sediments (late Miocene; see "Biostratigraphy") or communication with a compositionally different fluid below the base of Hole C0006F.

\section{Minor elements ( $\mathrm{B}, \mathrm{Li}, \mathrm{H}_{4} \mathrm{SiO}_{4}, \mathrm{Sr}$, and $\mathrm{Ba}$ )}

Boron decreases throughout the sediment section from $556 \mu \mathrm{M}$ at $1.3 \mathrm{~m}$ CSF to $94 \mu \mathrm{M}$ at $571.3 \mathrm{~m} \mathrm{CSF}$ ( $80 \%$ less than modern seawater value). B decreases most rapidly from the seafloor to the base of Subunit IIB at 163 m CSF. B gradually decreases in Subunits IIC and IID and is relatively constant, albeit with local scatter, in Unit III. Boron at Site C0006 is likely predominantly controlled by low-temperature alteration of volcanic ash with subsequent authigenic clay formation, as well as by B uptake by adsorption on clay minerals.

Lithium concentrations are above seawater value in the upper $\sim 2 \mathrm{~m}$ of the sediment section, and then rapidly decrease to below seawater value from 2 to
20 m CSF. Li remains relatively low, ranging between 7.3 and $20.2 \mu \mathrm{M}$ to $200 \mathrm{~m}$ CSF; local maxima are as high as $33 \mu \mathrm{M}$ (Fig. F40A). At $200 \mathrm{~m} \mathrm{CSF}$, Li gradually increases to the Subunit IIC/IID boundary. From this unit boundary, $\mathrm{Li}$ increases from $42 \mu \mathrm{M}$ at $406 \mathrm{~m}$ CSF to $136 \mu \mathrm{M}$ at $571 \mathrm{~m} \mathrm{CSF}$.

Dissolved silica increases rapidly from $437 \mu \mathrm{M}$ at $1.3 \mathrm{~m}$ CSF to $695 \mu \mathrm{M}$ at $12.2 \mathrm{~m}$ CSF, below which silica varies, ranging from $\sim 400$ to $1000 \mu \mathrm{M}$. Throughout the section at Site C0006, diatoms and radiolarians are either absent or very rare and fragmented (see "Lithology" and "Biostratigraphy"). Thus, the initial increase in $\mathrm{H}_{4} \mathrm{SiO}_{4}$ is likely due to the dissolution of siliceous biogenic material, whereas variations in silica below Unit I likely reflect varying dominant silicate diagenetic reactions. An increase in $\mathrm{H}_{4} \mathrm{SiO}_{4}$ in Unit III, as well as more variability in concentrations, likely reflects the change in depositional environment, lithology, and age of this unit.

Strontium rapidly decreases initially in the upper $12 \mathrm{~m}$ and remains below modern seawater value until $43.0 \mathrm{~m}$ CSF. At $76.4 \mathrm{~m} \mathrm{CSF}$, Sr sharply decreases, below which Sr increases to Subunit IID. Below Subunit IID, $\mathrm{Sr}$ is more variable and decreases with depth to the base of Hole C0006F (Fig. F40D). The slight $\mathrm{Sr}$ decrease in the upper $12 \mathrm{~m}$ reflects minor $\mathrm{Sr}$ precipitation in authigenic carbonates in the sulfatereduction zone. There was very little $\mathrm{CaCO}_{3}$ in the sediment section at Site C0006, which is mainly dominated by clays, quartz, and feldspars (see "Lithology"). This composition is reflected in the nearseawater concentration of $\mathrm{Sr}$ below the SMT to $\sim 300 \mathrm{~m}$ CSF. The steady increase in $\mathrm{Sr}$ from $300 \mathrm{~m}$ CSF to the middle of Subunit IID may reflect in situ volcanic ash diagenesis, as the concentration of ash and abundance of ash layers increase within this interval (see "Lithology").

Dissolved barium increases from $0.6 \mu \mathrm{M}$ at $1.3 \mathrm{~m}$ CSF to $12.7 \mu \mathrm{M}$ at $12.0 \mathrm{~m} \mathrm{CSF}$, which is $\sim 2 \mathrm{~m}$ below the base of the SMT. Ba remains remarkably constant, ranging from 9 to $19 \mu \mathrm{M}$ from $12.0 \mathrm{~m}$ CSF to the middle of Subunit IID. From $\sim 387$ m CSF, Ba increases and varies through Unit III to the base of Hole C0006F. The main Ba-containing phase in marine sediments is the mineral barite $\left(\mathrm{BaSO}_{4}\right)$, with aluminosilicates and Fe and Mn oxyhydroxides being the most important secondary phases. The mineral barite is stable under oxic conditions but becomes undersaturated and dissolves when pore fluid sulfate is depleted, releasing dissolved $\mathrm{Ba}$ to the pore fluids. The slight increase in pore fluid $\mathrm{Ba}$ in the upper $8 \mathrm{~m}$ of the sediment section is likely due to the dissolution of $\mathrm{Fe}$ and $\mathrm{Mn}$ oxyhydroxides during organic matter diagenesis. The increase in Ba across the SMT and with depth is most likely the result of barite 
dissolution in the sulfate depletion zone. The nearconstant dissolved $\mathrm{Ba}$ in Unit II is likely the manifestation of a near-uniform sedimentary barite content resulting from relatively rapid sedimentation of terrigenous material in a trench environment. The rapid increase in dissolved $\mathrm{Ba}$ in Subunit IID and Unit III is also likely related to the depositional environment. These sediments were deposited in an abyssal plaintype setting with less contribution of terrigenous material and a higher relative contribution of marine organic matter and biogenic barite.

\section{Trace elements \\ (Rb, Cs, V, Cu, Zn, Mo, Pb, and U)}

The pore fluid rubidium profile mimics the $\mathrm{K}$ profile (Fig. F40E, F40F). Rb decreases from above seawater value to $1.06 \mu \mathrm{M}$ at $43.0 \mathrm{~m} \mathrm{CSF}$ and then remains relatively constant in Subunits IIB and IIC at $\sim 1.0 \mu \mathrm{M}$. $\mathrm{Rb}$ decreases in Subunit IID and Unit III, reaching $\sim 0.45 \mu \mathrm{M}$ at the base of the hole $(\sim 30 \%$ less than modern seawater value). $\mathrm{Rb}$ is likely higher than seawater value in the upper $20 \mathrm{~m}$ of the sediment column because of cation exchange with $\mathrm{NH}_{4}$ on clays in the zone of most intense organic matter degradation and ammonium production. The general decline in $\mathrm{Rb}$ with depth likely reflects uptake by authigenic zeolites formed during volcanic ash alteration. The steady decrease in $\mathrm{Rb}$ in Unit III may reflect more mature ash diagenesis, given the older age of sediments within this unit, or communication with a low- $\mathrm{Rb}$ fluid at depths below the base of Hole C0006F. Dissolved Cs remains relatively constant from the seafloor to $405 \mathrm{~m} \mathrm{CSF}$, varying from 4.4 to $8.7 \mu \mathrm{M}$. Cs decreases within Subunit IID from $5.3 \mu \mathrm{M}$ at $405 \mathrm{~m} \mathrm{CSF}$ to $3.2 \mu \mathrm{M}$ at $406 \mathrm{~m} \mathrm{CSF}$ and then remains relatively constant to TD.

Vanadium is above seawater value and variable from 1.3 to 243.4 m CSF (Fig. F41D). Below this depth, V remains fairly constant with depth to the base of the hole, ranging from 4.7 to $33.8 \mathrm{nM}$. V is most variable in Unit I and Subunits IIB and IIC, with concentrations ranging from 6.9 to $89.5 \mathrm{nM}$. This variability in the $\mathrm{V}$ profile may indicate enhanced metal mobility in certain horizons and will be the focus of postcruise research. Fe is highly variable, ranging from 0 to $51 \mu \mathrm{M}$. In general, Fe is much higher in Unit I and Subunits IIA and IIB, which likely reflects ongoing microbially mediated organic matter oxidation using Fe oxyhydroxides as terminal electron acceptors. Subunits IIC and IID and Unit III as a whole exhibit low dissolved $\mathrm{Fe}$, except for peaks at 200,260 , and $340 \mathrm{~m}$ CSF.

Both dissolved zinc and molybdenum are highly variable, exhibiting scatter in each of the lithologic units. Mo ranges from 26 to $850 \mu \mathrm{M}$, and dissolved $\mathrm{Zn}$ ranges from 30 to $1294 \mathrm{nM}$. In general, Mo and
Zn are relatively lower in Unit I and Subunit IIA and higher in Subunits IIB-IID and Unit III. Copper concentration is relatively low and variable in Unit I and Subunits IIA-IID, ranging from 57 to $8466 \mathrm{nM}$. There is a sharp increase in $\mathrm{Cu}$ across the Subunit IID/Unit III boundary, reflecting a change in lithology. $\mathrm{Cu}$ is variable in Unit III, ranging from 696 to 31,893 nM.

Uranium decreases abruptly from $25.7 \mathrm{nM}$ at $1.3 \mathrm{~m}$ CSF to $0.7 \mathrm{nM}$ at $4.4 \mathrm{~m} \mathrm{CSF}$ (Fig. F42). Uranium is more soluble under oxidizing conditions than reducing conditions; thus the rapid decline in $U$ is the manifestation of the rapid depletion of dissolved oxygen in the upper part of the sediment section. $\mathrm{U}$ remains low with an average concentration of $1.5 \mathrm{nM}$ in Unit I and Subunits IIA-IID. U is slightly higher and more variable in Unit III with a maximum concentration of $9.2 \mathrm{nM}$. Lead is relatively low in Unit I and Subunits IIA-IID, with peaks at 17.4, 137.5, 329.0, and $404.9 \mathrm{~m} \mathrm{CSF}$. Average $\mathrm{Pb}$ concentration increases in Unit III. The enrichment in $\mathrm{U}$ and $\mathrm{Pb}$ in Unit III reflects a change in lithology. Yttrium concentration generally decreases with depth, ranging from $6.4 \mathrm{pM}$ at $12.2 \mathrm{~m} \mathrm{CSF}$ to $0.15 \mathrm{pM}$ at TD.

$$
\delta^{18} \mathrm{O}
$$

Pore fluid $\delta^{18} \mathrm{O}$ varies from $0.19 \%$ to $-4.19 \%$ (Fig. F43). From 1.3 to $81.9 \mathrm{~m} \mathrm{CSF}$ (bottom of Subunit IIA), the $\delta^{18} \mathrm{O}$ profile is characterized by a steady decrease in values to $-3.00 \%$. Below this depth, $\delta^{18} \mathrm{O}$ remains relatively constant to $\sim 400 \mathrm{~m} \mathrm{CSF}$, the base of Subunit IID. $\delta^{18} \mathrm{O}$ is variable in Unit II, with a prominent peak of $-1.60 \%$ at $439 \mathrm{~m}$ CSF.

\section{Summary and discussion}

The primary features of the pore fluid geochemical profiles collected at Site C0006 are

1. Relatively shallow SMT and high burial rates and input of terrigenous material in Unit I and Subunits IIA, IIB, and IIC;

2. Disseminated gas hydrates with localized occurrences of elevated pore space gas hydrate concentrations;

3. No detectable recent fluid flow from depth along the imbricate thrust faults above the deformation front; and

4. Distinct change in pore fluid chemistry and isotopic composition in Unit III.

\section{Microbially mediated reactions and high influx of terrigenous sedimentary material}

The pore fluid profiles in the upper $\sim 60 \mathrm{~m}$ of the sediment column are dominated by microbially mediated reactions, and the SMT is reached at 8-12 m CSF. Above this interface, sulfate-reducing microbial 
communities utilize interstitial sulfate to oxidize sedimentary organic matter, reducing sulfate to sulfide and producing bicarbonate by Reaction 1:

$$
2 \mathrm{CH}_{2} \mathrm{O}+\mathrm{SO}_{4}{ }^{2-} \rightarrow \mathrm{H}_{2} \mathrm{~S}+2 \mathrm{HCO}_{3} .
$$

Below the interface, methanogens generate methane. At the interface in some environments (especially diffusive settings), microorganisms symbiotically reduce sulfate and oxidize methane by a biogeochemical process called anaerobic oxidation of methane (AOM). The net biogeochemical process is described by Reaction 2 (Reeburgh, 1976):

$$
\mathrm{CH}_{4}+\mathrm{SO}_{4}{ }^{2-} \rightarrow \mathrm{HCO}_{3}{ }^{-}+\mathrm{HS}^{-}+\mathrm{H}_{2} \mathrm{O} .
$$

Pore fluid alkalinity reaches a maximum of $25.78 \mathrm{mM}$ at the depth of the SMT. Based on Reactions 1 and 2, if sulfate reduction by oxidation of organic matter is the dominant process controlling sulfate to the depth of the SMT, then two moles of alkalinity are produced for each mole of $\mathrm{SO}_{4}$ reduced ( 60 moles of alkalinity). If AOM is the dominant process controlling pore fluid sulfate, then one mole of alkalinity is produced for each mole of $\mathrm{SO}_{4}$ reduced ( $\sim 30$ moles of alkalinity). Alkalinity at the SMT is less than expected from both processes because of the active formation of authigenic carbonate at this interval, which is manifested by the sharp decrease in $\mathrm{Ca}$ and $\mathrm{Mg}$ from the seafloor to slightly below the SMT. Although the linearity of the $\mathrm{SO}_{4}$ reduction profile and relatively low alkalinity suggest that AOM is the dominant process controlling sulfate, the large decreases in Ca and $\mathrm{Mg}$ to the SMT indicate that ordinary organic matter oxidation is also a control. Shorebased $\delta^{13} \mathrm{C}$-DIC analyses will aid in constraining the relative extent of AOM at this site.

Ammonium increases below the SMT, reaching a broad maximum of $\sim 6000 \mu \mathrm{M}$ between $\sim 72$ and $200 \mathrm{~m}$ CSF. This broad zone of elevated $\mathrm{NH}_{4}$ is likely due to the combination of ongoing organic matter degradation and high burial rates (combination of high sedimentation rates and thrust faulting) at this site. Unit I has a slope association and Subunits IIA, IIB, and IIC were deposited in a trench environment where sedimentation rates are high and dominated by terrigenous material (see "Lithology"). The amount of terrigenous material and deposition rate increase upsection. Thus, the broad maximum in $\mathrm{NH}_{4}$ is likely the manifestation of high sedimentation rates effectively burying ammonium more quickly than diffusion and advection across the sediment/water interface could remove it. Sedimentation rates are lower and the amount of terrigenous material decreases with depth in Subunits IIC and IID where ammonium gradually decreases. Unit III is in- terpreted to be a deepwater marine environment with low terrigenous material input and sedimentation rates, and within this unit ammonium decreases. The greater proportion of terrigenous material in comparison to marine material is corroborated by overall low $\mathrm{Br}$, which suggests degradation of terrestrial organic matter is much more prominent than degradation of marine organic matter in the upper sediment section. Br then decreases with depth into Unit III, indicating lower rates of organic matter degradation. The higher amount of terrestrial material in the upper sediment section is also observed in pore fluid $\mathrm{Ba}$, which is relatively low in Unit I and Subunits IIA, IIB, and IIC, likely reflecting dilution of biogenic barite by terrigenous material. Ba increases in Unit III, which was likely deposited in a deepwater marine environment seaward of the deformation front. This type of depositional environment would have a lower contribution from terrigenous sources and thus would have higher biogenic barite concentration.

\section{Gas hydrate occurrence}

The relatively shallow SMT at Site C0006 suggests an elevated upward methane flux and the heat flow is anomalously low for this region (see "Physical properties"), both of which provide ideal conditions for gas hydrate formation in the sediment column. The thermal gradient at Site $\mathrm{C} 0006$ is $27^{\circ} \mathrm{C} / \mathrm{km}$, compared with $>50^{\circ} \mathrm{C} / \mathrm{km}$ at Sites C0004 and C0008 (see "Physical properties"), and the bottom water temperature is $2^{\circ} \mathrm{C}$. Assuming equilibrium with Structure I gas hydrate, the CSMHYD program of Sloan (1998) was used to compute the gas hydrate stability field at this site. From the thermal gradient, the gas hydrate stability field for Structure I gas hydrate extends from the seafloor to $\sim 800-850 \mathrm{~m}$. Pore fluid $\mathrm{Cl}$ from $\sim 100$ to $\sim 500$ m CSF gradually declines from 571 to $540 \mathrm{mM}$, which likely reflects dissociation of disseminated gas hydrates within the sediment pore space during core recovery. The gradual decrease in pore fluid $\mathrm{Cl}$ indicates that gas hydrate, though overall very low, increases with depth. Using a background pore fluid value of $568 \mathrm{mM}$, the pore space gas hydrate ranges from negligible to $<2 \%$ within the sediment column. Superimposed on the gradual decline in $\mathrm{Cl}$ are two $\mathrm{Cl}$ minima of $526 \mathrm{mM}$ at $76 \mathrm{~m} \mathrm{CSF}$ and $533 \mathrm{mM}$ at 292 m CSF, which indicate horizons of elevated gas hydrate occurrence; however, hydrate concentrations at these two depths are still relatively low, comprising less than $\sim 5 \%$ of the sediment pore space.

\section{Pore fluid geochemical profiles through fault zones}

The pore fluid geochemical profiles are relatively smooth through the deformation zone at Site C0006, 
which is characterized by a zone of imbricate thrust faults extending from 2275 to $540 \mathrm{~m}$ CSF (see "Structural geology"). Within this deformation zone, $\mathrm{Ca}, \mathrm{Sr}$, and $\mathrm{Li}$ steadily increase and $\mathrm{Cl}, \mathrm{Na}, \mathrm{Mg}$, $\mathrm{B}, \mathrm{K}$, and $\mathrm{Rb}$ decrease. There are no local maxima or minima coincident with the faults at Site C0006; thus, there is a lack of evidence for recent updip flow of fluids from greater depths along these fault zones, suggesting that either recent rupture has been localized, fault permeability is not enhanced during slip events, or these faults have been inactive in the recent past.

From $\sim 500 \mathrm{~m}$ CSF to the base of the hole at $\sim 600 \mathrm{~m}$ CSF, there are distinct changes in many of the pore fluid chemical profiles. Within this interval, Li and $\mathrm{Ca}$ markedly increase and $\mathrm{Cl}, \mathrm{K}$, and $\mathrm{Rb}$ decrease. Sediments at the base of Hole C0006F, comprising Unit III, are late Miocene in age (see "Biostratigraphy"), and the geochemical variations could reflect more mature diagenetic reactions because of the greater potential age of pore fluids. Another possibility is that these fluids reflect diffusional communication with a fluid originating deeper than the base of Hole C0006F, potentially residing in faults and fractures associated with the frontal thrust.

\section{Organic geochemistry}

At Site C0006, four holes were drilled. In Holes C0006C and C0006D, the mudline was not confirmed. Because of the unknown depths (see "Inorganic geochemistry"), data from these holes are included in tables (Tables T15, T16, T17) but are not shown in figures.

\section{Hydrocarbon gas composition}

At Site C0006, the SMT zone is at $\sim 8-12 \mathrm{~m} \mathrm{CSF}$, which is a few meters shallower than at Site C0004 (Table T16; Fig. F44). The methane depth profile below $14 \mathrm{~m}$ CSF decreases throughout the sediment column (except for two peaks at $\sim 100$ and $310 \mathrm{~m}$ CSF). These increased methane values are obtained only a few meters below the occurrence of measured chloride anomalies that suggest the occurrence of gas hydrates (see "Inorganic geochemistry"). Thus, the enrichment in methane content at these two intervals could be related to the destabilization of gas hydrates and the subsequent release of methane into the sediment. Ethane was detected in low amounts in the sediment below $76 \mathrm{~m}$ CSF. Higher molecular weight hydrocarbons were not detected at Site C0006. The methane/ethane $\left(\mathrm{C}_{1} / \mathrm{C}_{2}\right)$ ratio remains high throughout the sediment column, indicating biogenic origin of the hydrocarbon gases.

\section{Sediment carbon, nitrogen, and sulfur composition}

The amount of calcium carbonate $\left(\mathrm{CaCO}_{3}\right)$ in sediments at Site C0006 is lower than that at Site C0004 (Table T17; Fig. F45). The highest values were obtained in Unit I, with a maximum concentration of $6.2 \mathrm{wt} \%$, followed by a decrease in Subunit IIA. This is consistent with calcite data obtained from XRD measurements (see "Lithology"). A slight increase in $\mathrm{CaCO}_{3}$ occurs at the Unit II/III boundary. The highest carbonate value was measured at the bottom of Hole C0006F.

Except for a few enrichments, total organic carbon (TOC) remains low throughout the core (average $=$ $0.46 \mathrm{wt} \%)$. Total nitrogen (TN) increases throughout Unit III. Because ammonium concentration decreases (see "Inorganic geochemistry") and total clay content is higher in Unit III (see "Lithology"), the TN enrichment is probably related to clay-bound nitrogen substances. The ratio of TOC to $\mathrm{TN}(\mathrm{C} / \mathrm{N})$ averages $\sim 7.0$, indicating that organic matter at Site $\mathrm{C0006}$ is mainly of marine origin. A few higher values indicate that some terrigenous organic compounds are present in lower concentrations in Units I and II.

Total sulfur (TS) concentration in sediments is generally low (average $=0.25 \mathrm{wt} \%$ ). In Unit I, TS is higher, showing a maximum of $1.7 \mathrm{wt} \%$ at $\sim 17 \mathrm{~m} \mathrm{CSF}$. The enrichment is below the SMT and can most likely be associated with the precipitation of fine-grained iron sulfides. This will be evaluated by shore-based analyses of samples. In Unit II, TS concentration remains low (average $=0.2 \mathrm{wt} \%$ ) and slightly increases again in Unit III to $0.77 \mathrm{wt} \%$. The higher TS concentration below $\sim 500 \mathrm{~m}$ CSF can be related to the occurrence of small pyrite nodules (see Fig. F6).

Additionally, three samples from $370.18,370.67$, and $371.05 \mathrm{~m}$ CSF were analyzed (data are not included in figures). The samples were selected from woodbearing sediments in turbidite sequences (see Fig. F6). TS concentrations in these samples are 1.8, 2.66, and $2.32 \mathrm{wt} \%$, respectively. TOC and TN concentrations are up to 10 times higher than in the surrounding sediments, with TOC contents of $3.8,6.87$, and $3.91 \mathrm{wt} \%$, respectively, and TN contents of $0.1,0.15$, and $0.11 \mathrm{wt} \%$, respectively. The mean $\mathrm{C} / \mathrm{N}$ ratio of the three samples is $\sim 40$.

\section{Microbiology and biogeochemistry}

\section{Sample processing}

To study microbiological and biogeochemical characteristics in sediments at Site C0006, samples were 
obtained from 143 different depth locations (Table T18). Almost all sample processing was carried out after X-ray CT scanning and was completed within $1 \mathrm{~h}$ after core recovery on deck.

\section{Cell abundance}

Using paraformaldehyde-fixed slurry samples, preliminary microbial cell abundances were enumerated by visual inspection using the SYBR Green I staining method (Lunau et al., 2005, see "Microbiology and biogeochemistry" in the "Expedition 316 methods" chapter). At Site C0006, $\sim 10^{9}$ cells $/ \mathrm{cm}^{3}$ were detected in the upper lithologic unit above $100 \mathrm{~m}$ CSF. An apparent increase of microbial biomass was observed in sand layers, possibly suggesting the occurrence of energy supply via fluid circulation. Below the upper lithologic unit, microbial population decreased with depth in the accretionary prism, which is in good agreement with typical cell abundance tendencies that have been observed in global marine subsurface sediments (Parkes et al., 2000). In the accretionary prism, no or very small proliferation of cell abundance was observed in sand layers and at the Unit II/ III boundary (Fig. F46). Most cells were tiny coccoids, but rod-shaped cells were also observed as minor components (Fig. F47). Generally, the microbial population in the accretionary prism at Site C0006 was found to be low $\left(10^{7}\right.$ cells $\left./ \mathrm{cm}^{3}\right)$, which is in clear contrast to the constant and abundant microbial population $\left(10^{9}\right.$ cells $\left./ \mathrm{cm}^{3}\right)$ at Site C0004. Average cell abundance in sediments at Site C0006 was estimated to be $6.19 \times 10^{8} \pm 2.27 \times 10^{8} \mathrm{cells} / \mathrm{cm}^{3}(N=27)$.

Given the cell abundance profile at Site C0006, it is hypothesized that the microbial population size may indicate the energy status of the subsurface. The microbial population generally decreases with increasing depth because of the limited availability of nutrient and energy sources that support microbial growth activity. If the decreasing population ratio indicates the balance point between community size and life maintenance energy (Hoehler, 2004), the accretionary prism at Site C0006 may be a harsh and energy-starved habitat for subseafloor life. It is a clear contrast to the accretionary prism at Site C0004, where relatively high biomass is present throughout the cored materials (Fig. F46). In addition, it is worth noting that the energy flux does not always indicate flux or hydrological movement of interstitial water; dehydration of smectite or physical compaction may induce water flux along faults and/ or fractures, but the fluids do not always contain the energy (nutrient) substrates required for microbial life. On the other hand, porous sand layers in the upper unit harbor abundant microbial populations, suggesting that the environment is rich in available energy sources and habitable space. The potential energy sources in the sand layers are probably buried consumable organic matter (e.g., organic acids) and/ or substrates derived from fluid circulation.

\section{Physical properties}

At Site C0006, physical property measurements were made to provide basic information characterizing lithologic units, states of consolidation, deformation, and strain and to correlate coring results with downhole logging data. After capturing X-ray CT images and the core reached thermal equilibrium with ambient temperature at $\sim 20^{\circ} \mathrm{C}$, gamma ray attenuation (GRA) density, magnetic susceptibility, natural gamma radiation, $P$-wave velocity, and noncontact electrical resistivity were measured using a multisensor core logger (MSCL) system on whole-round core sections (MSCL-W). Thermal conductivity was measured using either a full-space needle probe method or a half-space line source method on split working halves. The half-space method was used on lithified sediments deeper in the hole that were impenetrable with the needle probe. Cores were split in two longitudinally, one half for archiving and one half for sampling and analysis. A photo image capture logger (MSCL-I) and a color spectrophotometer (MSCL-C) were used to collect images of the split surfaces of the archive halves. Moisture and density (MAD) were measured on discrete subsamples collected from the working halves as well as from "clusters" adjacent to whole-round samples removed before splitting. Vane shear and penetration experiments were performed on the working halves to $270 \mathrm{~m} \mathrm{CSF}$. Additional discrete subsamples from working halves were used to perform electrical conductivity measurements, $P$-wave velocity measurements, and anisotropy calculations.

\section{Density and porosity}

Bulk density values at Site C0006 were determined from both GRA measurements on the MSCL and MAD measurements on discrete samples from the working halves of split cores (see "Physical properties" in the "Expedition 316 methods" chapter). A total of 613 discrete samples were analyzed for MAD (14 from Hole C0006C, 14 from Hole C0006D, 507 from Hole C0006E, and 78 from Hole C0006F).

MAD wet bulk density increases dramatically from 0 to $\sim 38 \mathrm{~m} \mathrm{CSF}$ and then decreases slightly from $\sim 38$ to $\sim 50 \mathrm{~m} \mathrm{CSF}$, followed by a gradual increase to $\sim 400 \mathrm{~m}$ CSF (Fig. F48A). Maximum MSCL bulk density values (one component of the MSCL logging suite) also show similar trends. MSCL bulk density is generally lower than MAD bulk density, likely because of voids in the unsplit cores, and reveals a 
larger degree of scatter compared to density from discrete samples. The scatter in MAD bulk density is likely due to lithologic variations among the interbedded sand, silt, and mud at this site. Grain density averages $\sim 2.7 \mathrm{~g} / \mathrm{cm}^{3}$ (Fig. F48B) and increases slightly $\left(\sim 0.05 \mathrm{~g} / \mathrm{cm}^{3}\right)$ from 0 to $570 \mathrm{~m}$ CSF. Grain density values $>3 \mathrm{~g} / \mathrm{cm}^{3}$ are likely artifacts.

Porosity was estimated from whole-round core MSCL scans and calculated from MAD measurements on discrete samples. MAD porosity (see "Physical properties" in the "Expedition 316 methods" chapter) generally decreases with depth (Fig. F48C) and varies inversely with bulk density. Because of the greater scatter in MSCL density and porosity values, we focus on bulk density and porosity values calculated from MAD measurements.

\section{Density and porosity of lithologic units}

At Site C0006, bulk density of the Pleistocene trenchslope transition package of mud and interbedded sand comprising Unit I (see "Lithology") increases in the upper $5 \mathrm{~m}$ from $\sim 1.80$ to $\sim 1.90 \mathrm{~g} / \mathrm{cm}^{3}$ and then gradually increases from $\sim 1.90$ to $1.92 \mathrm{~g} / \mathrm{cm}^{3}$ with depth to $27 \mathrm{~m}$ CSF (Fig. F48A). As density increases, porosity decreases (Fig. F48C).

Unit II is composed of trench-wedge and trenchbasin transitional sand, silt, and mud of Pleistocene age (see "Lithology"). From Subunit IIA through the upper one third of Subunit IID (i.e., from 227 to $\sim 410 \mathrm{~m} \mathrm{CSF}$ ), bulk density gradually increases from $\sim 1.92$ to $\sim 2.07 \mathrm{~g} / \mathrm{cm}^{3}$ (Fig. F48A). This trend is mirrored by a gradual decrease in porosity with depth from $\sim 46 \%$ at the top of Unit II to $\sim 38 \%$ at $\sim 410 \mathrm{~m}$ CSF (Fig. F48C). Gaps in the data in Unit II mark regions of low core recovery and likely indicate the presence of fault zones (see "Structural geology"). In the bottom two-thirds of Subunit IID (from $\sim 410$ to $\sim 450 \mathrm{~m} \mathrm{CSF}$ ), bulk density decreases rapidly from $\sim 2.07$ to $1.94 \mathrm{~g} / \mathrm{cm}^{3}$ (Fig. F48A), whereas porosity increases from $\sim 39 \%$ to $\sim 49 \%$ (Fig. F48C).

From $\sim 450$ to $\sim 475 \mathrm{~m} \mathrm{CSF}$, bulk density decreases and porosity increases. At $\sim 475 \mathrm{~m} \mathrm{CSF}$, however, the bulk density and porosity trends reverse, increasing and decreasing, respectively, with increasing depth (Fig. F48A, F48C). From $\sim 475$ to $570 \mathrm{~m} \mathrm{CSF}$, bulk density increases from $\sim 1.90$ to $\sim 2.10 \mathrm{~g} / \mathrm{cm}^{3}$ (Fig. F48A). Similarly, porosity decreases dramatically from $\sim 49 \%$ to $\sim 40 \%$ from $\sim 475$ to $\sim 570$ m CSF.

\section{Relationships of density and porosity changes with unit and structural boundaries}

MAD-derived bulk density and porosity increase and decrease, respectively, from 0 to $\sim 410 \mathrm{~m}$ CSF and re- veal no clear discontinuities at depths corresponding to possible faults at 235,277 , and $367 \mathrm{~m}$ CSF or at the Unit I/Subunit IIA, Subunit IIA/IIB, or Subunit IIC/IID lithologic boundaries within that depth range. A discontinuity in the porosity versus depth trend at $\sim 410 \mathrm{~m}$ CSF occurs within Subunit IID and coincides with a thrust fault at $\sim 410 \mathrm{~m}$ CSF inferred from seismic reflection data and above the top boundary of the shear zone in the interval from 434 to $440 \mathrm{~m}$ CSF identified in the split core.

The zone of highest porosity $(\sim 50 \%)$ between $\sim 450$ and $\sim 490 \mathrm{~m}$ CSF is bounded by faults. This zone of elevated porosity possibly results from increased occurrences of fluid-filled microcracks and other faultrelated damage. Alternatively, elevated porosity in this zone could indicate that these sediments are underconsolidated, reflecting elevated fluid pressures, which may have localized shear deformation in this region. We note that although mud and silt samples from these zones of elevated porosity appear to be well-indurated chunks of material, they are actually quite friable in hand sample. This observation suggests that these are zones of fault-related damage. In either case, this interval appears to be a zone of significant faulting.

We also note that the interval of elevated porosity appears to correlate with an interval of increased clay content. Lithologic analyses of the split core reveal that Unit III exhibits an overall increase in clay content and decreases in quartz and feldspar contents compared to the overlying Subunit IID (see "Lithology"). Clays may lead to spuriously high porosity because the drying process during MAD measurement removes interlayer water from smectite (Brown and Ransom, 1996). Clays may also decrease permeability of sediments and rocks in this interval, allowing pore fluid overpressures to develop more easily.

From $\sim 490$ to $570 \mathrm{~m} \mathrm{CSF}$, porosity decreases with depth, though porosity values in this interval are still higher than might be predicted based on the overall trend observed from $\sim 5$ to $410 \mathrm{~m}$ CSF. These higher than expected porosity values are probably explained in part by lithologic and compositional differences between units, which result in different porosity-depth trends. The mismatch may also indicate that rocks in this interval are significantly damaged by the overlying fault or faults from $\sim 434$ to $\sim 490 \mathrm{~m}$ CSF and the faults from $\sim 533$ to $\sim 560 \mathrm{~m} \mathrm{CSF}$, identified on the basis of seismic data and structural geology observations. Alternatively, the high porosity could be due to the presence of interlayer water in clays and/or overpressured fluids. 


\section{$P$-wave velocity and electrical conductivity in discrete samples}

$P$-wave velocity and electrical conductivity were measured on cubic samples along $x-, y$-, and $z$-directions of the core reference (see "Physical properties" in the "Expedition 316 methods" chapter). Samples were relatively indurated, and no noticeable disaggregation was observed when immersed in seawater. This induration is in marked contrast to the behavior observed in samples from Site C0004 through the shallow megasplay. The electrical conductivity data set is more extensive than that collected for $P$-wave velocity. The instrument used to measure $P$-wave velocity requires an applied normal stress of $\sim 120 \mathrm{kPa}$, which caused deformation to samples from depths shallower than $230 \mathrm{~m} \mathrm{CSF}$, voiding the measurement. Conversely, in some deeper cores, $P$-wave velocity measurements were easier to obtain because of the difficulty of sawing adequate faces for electrical conductivity measurements. Results of electrical conductivity, $P$-wave velocity, and associated anisotropy measurements are plotted in Figure F49.

Electrical conductivity (Fig. F49A) decreases overall with depth. Although the data are highly scattered throughout the uppermost $300 \mathrm{~m}$, below $300 \mathrm{~m} \mathrm{CSF}$ electrical conductivity manifests two recognizable trends in the intervals from $\sim 300$ to $\sim 400 \mathrm{~m} \mathrm{CSF}$ and from 470 to $600 \mathrm{~m}$ CSF. Both trends show a decrease in electrical conductivity but are offset by $\sim 10 \%$ through an increase in electrical conductivity within Subunit IID. These trends and offsets are also observed in LWD resistivity-at-the-bit (RAB) data, which improves our confidence that this pattern is real (see the "Expedition 314 Site C0006" chapter). Additionally, these trends mimic trends observed in MAD porosity (Fig. F48C). MAD porosity values are offset by $\sim 10 \%$, similar to the offset observed in electrical conductivity data. Between 410 and $470 \mathrm{~m} \mathrm{CSF}$, poor core condition prevented adequate sampling.

Electrical conductivity anisotropy shows considerable scatter at depths shallower than $300 \mathrm{~m}$ CSF (Fig. F49B). At $\sim 200 \mathrm{~m} \mathrm{CSF}$, three sets of measurements indicate high anisotropy and are associated with significantly lower magnitudes of electrical conductivity. Between 300 and $400 \mathrm{~m} \mathrm{CSF}$, transverse anisotropy decreases with depth and, coupled with the decrease in electrical conductivity (Fig. F49A), might indicate progressive compaction with depth.

$P$-wave velocity (Fig. F49C) increases from $\sim 1800 \mathrm{~m} / \mathrm{s}$ a little below $200 \mathrm{~m}$ CSF to $\sim 2100 \mathrm{~m} / \mathrm{s}$ near the bottom of Hole C0006E. At $\sim 300 \mathrm{~m} \mathrm{CSF}$ and again at $\sim 400 \mathrm{~m} \mathrm{CSF}$ are two zones that correspond to increased scatter in both $P$-wave velocity and electrical conductivity measurements. $P$-wave velocity also decreases by as much as $300 \mathrm{~m} / \mathrm{s}$ through discrete in- tervals at 520, 550, and $570 \mathrm{~m} \mathrm{CSF}$. Although these velocity differences could potentially be associated with faults, microstructural data are needed to conclusively establish the cause of these low-velocity zones. The anisotropy of $P$-wave velocity (Fig. F49D) generally decreases with depth with two discrete zones of higher transverse anisotropy at $\sim 400$ and $\sim 480 \mathrm{~m}$ CSF.

\section{Thermal conductivity}

Thermal conductivity measurements were conducted on whole-round HPCS and ESCS cores $(<316 \mathrm{~m}$ CSF) and on split core samples from RCB cores from $>316 \mathrm{~m}$ CSF. Thermal conductivity ranges from 0.51 to $1.61 \mathrm{~W} /(\mathrm{m} \cdot \mathrm{K})$ (Table T19; Fig. F50A). Thermal conductivity from the seafloor to $\sim 80 \mathrm{~m}$ CSF shows a striking positive excursion through Unit I and Subunit IIA that likely reflects higher sand content through this interval. A negative trend in thermal conductivity is observed through Subunit IIA, likely reflecting a decrease in sand content. Between $\sim 80$ and $400 \mathrm{~m} \mathrm{CSF}$, thermal conductivity generally increases, likely reflecting decreasing porosity. As porosity decreases, thermal conductivity increases as water is forced out of void spaces because the thermal conductivity of sediment is greater than water. Thermal conductivity values in this region show large scatter relative to the mean, likely reflecting the effects of interbedded sands and clays. Thermal conductivity in Unit III increases with depth but is offset to lower values relative to the trend through Subunits IIB and IIC.

\section{In situ temperature}

In situ temperature was measured using both the APCT3 and DVTP. Three of six deployments of the APCT3 and three of seven deployments of the DVTP were successful (Table T20). All measurements were made in calm to moderate seas. Temperature-time series for each temperature measurement are shown in Figure F51. The temperature tool was stopped at the mudline for as long as $10 \mathrm{~min}$ prior to each penetration. The average apparent bottom water temperature is $1.65^{\circ} \mathrm{C}$ (Table T20). Significant frictional heating occurred on all penetrations, and the temperature versus time records exhibit the characteristic probe penetration heating pulse and subsequent decay (Fig. F51). Equilibrium temperature estimates are based on a 1/time approximation from the temperature-time series while the tool is in the bottom sediments. The effective origin time of the thermal pulse associated with tool penetration was estimated by varying the assumed origin time until the thermal pulse decay followed the theoretical curve. A delay of 15-106 s from the initial penetration heating time 
was found to be required to give a linear $1 /$ time plot. Because of tool movement in the bottom, the time over which equilibrium temperatures are estimated is variable. Equilibrium temperature estimates are based on relatively short fits at 98.3 and $220.3 \mathrm{~m} \mathrm{CSF}$ with fitting times of 2.8 and $3.3 \mathrm{~min}$, respectively. However, in spite of the short period over which these equilibrium temperatures are estimated, and with the exception of the measurement at $277.3 \mathrm{~m}$ CSF, resulting temperatures form a relatively constant gradient with depth giving confidence to individual temperature determinations (Fig. F50B). Additionally, it is important to note that temperature derived from both the APCT3 and DVTP give consistent results.

Equilibrium temperatures as a function of depth are quite linear, with the exception of the measurement at $277.3 \mathrm{~m} \mathrm{CSF}$. The best fitting thermal gradient through the first six measurements is $27^{\circ} \mathrm{C} / \mathrm{km}$ (Fig. F50B). The equilibrium temperature at $277.3 \mathrm{~m} \mathrm{CSF}$ falls well below the thermal gradient derived above with a temperature only slightly warmer than bottom water. The low thermal gradient coupled with this anomalously cold temperature at depth suggests that colder than normal conditions exist around Hole C0006E.

\section{Heat flow}

If heat transfer is by conduction and heat flow is constant, the thermal gradient will be inversely proportional to thermal conductivity according to Fourier's law. This relationship can be linearized by plotting temperature as a function of summed thermal resistance (Bullard, 1939) (see the "Expedition 316 methods" chapter) (Fig. F50C). In the following analysis, the temperature measurement at $277.3 \mathrm{~m}$ CSF is not included. The least-squares fit to the temperature and thermal resistance data indicates a heat flow of $33 \mathrm{~mW} / \mathrm{m}^{2}$ and a bottom water temperature of $2.1^{\circ} \mathrm{C}$. The estimated bottom water temperature is only $0.4^{\circ} \mathrm{C}$ different than the measured apparent bottom water temperature (Table T19). Predicted temperature deviates from those measured by $<0.2^{\circ} \mathrm{C}$. With the exception of the measurement at $277.3 \mathrm{~m}$ CSF, a constant conductive heat flow appears to describe the overall thermal structure quite well. This heat flow value is anomalously low with respect to other heat flow values along the Nankai Trough and in the vicinity of the Kii transect (Yamano et al., 2003).

Two features of the temperature-depth profile at Site C0006 are important. The first is the very low but constant thermal gradient, which gives rise to an anomalously low heat flow value. The second feature is the low temperature measurement at $277.3 \mathrm{~m} \mathrm{CSF}$.
The heat flow value appears to be a local feature because it is anomalously low relative to heat flow values at Sites C0004 and C0007, as well as regional data determined from gravity-driven probes. Possible explanations for this locally low heat flow value include the dissociation of hydrate and local downward flow of seawater. Because of the low thermal gradient, depths drilled at Site C0006 are all within the hydrate stability zone, precluding the widespread dissociation of hydrate. The lack of widespread hydrate is also confirmed by both interstitial water geochemistry and methane measurements on cores. Inorganic geochemistry results do not indicate downward fluid flow. However, downward fluid flow seaward of Hole C0006E but close to the hole may induce the locally low thermal gradient. The low temperature measurement at $277.3 \mathrm{~m} \mathrm{CSF}$ is $6.6^{\circ} \mathrm{C}$ cooler than predicted by the best-fit conductive gradient (Fig. F50B). This temperature measurement coincides with a sharp negative anomaly in both sodium and chlorinity concentrations (see "Inorganic geochemistry") consistent with the local presence of methane hydrates. However, a $6.6^{\circ} \mathrm{C}$ temperature drop associated with the dissociation of hydrate seems implausible. Another explanation for the low temperature measurement is the infiltration of cold bottom water through the sediments prior to the temperature measurement because of drilling disturbance. The lithology at this depth is sandy silt and core recovery was poor (recovery $=38 \%$ ). Thus it is possible that the low temperature reflects intrusion of seawater prior to the temperature measurement. Discerning the cause of the low heat flow will require additional work.

\section{Shear strength}

Shear strength measurements were determined using a semiautomated miniature vane shear device and a pocket penetrometer. Measurements were made at discrete locations on the working halves of split cores at a frequency of approximately three measurements per core in sections 2, 5, and 7. Tests were conducted on relatively intact and homogeneous regions of these sections, generally somewhere between 50 and $100 \mathrm{~cm}$ below the top of the section. To minimize error induced by disturbance of the core by the measurement technique, vane shear tests were conducted first, followed by penetrometer tests $1-2 \mathrm{~cm}$ from the site of the vane shear penetration, followed by MAD sampling. No vane shear measurements were conducted on whole cores. Both instruments were inserted orthogonally to the surface of the working halves. The rotation rate of the semiautomated vane shear apparatus on board the Chikyu is $71^{\circ} / \mathrm{min}$. 
Results of shear strength measurements from the vane shear and penetrometer methods are presented in Figure F52. Both measurement techniques were applied at regular intervals to $270 \mathrm{~m}$ CSF in Hole C0006E. An additional measurement was taken in an apparently unconsolidated sandy layer in Core 316C0006E-31X at $321 \mathrm{~m} \mathrm{CSF}$, but this was not a characteristic lithology for either the core or Subunit IIC as a whole.

We observe a rapid increase in shear strength in the uppermost $40 \mathrm{~m}$ CSF in all of Unit I and into the top of Subunit IIA. At $40 \mathrm{~m}$ CSF, shear strength drops rapidly and is associated with the prevalence of sandy beds. Both vane shear and penetrometer measurements may differ for fine-grained and coarsegrained sediments because of variations in partial drainage behavior during the test. Deformation of low-permeability clay-rich sediments is likely to be nearly undrained, whereas the deformation of highly permeable coarse-grained sediments is likely to be nearly drained. As a result, direct comparison between values for substantially different lithologies is not straightforward.

The Subunit IIA/IIB boundary is coincident with an increase in shear strength at $72 \mathrm{~m}$ CSF. A similar increase at $110 \mathrm{~m}$ CSF does not appear to correlate with a significant lithologic change. Shear strength continues to increase to $200 \mathrm{~m}$ CSF. Between 200 and $275 \mathrm{~m} \mathrm{CSF}$, there is an apparent decrease in shear strength. This decrease will need to be corroborated by shore-based research, as there is some bias in both methods due to changing deformation style as rocks become more cohesive. Vane shear and penetrometer techniques are designed for pervasive deformation and failure of sediments and are not calibrated for measuring materials that fail because of the formation of discrete fractures.

\section{Color spectrometry}

Results from the measurement of color reflectance are presented in Figure F53. The $\mathrm{L}^{*}$ values range from $\sim 20$ to 50 . The $\mathrm{a}^{*}$ values range from -2 to 2 and the $\mathrm{b}^{*}$ values range from 0 to 4 . At less than $\sim 100 \mathrm{~m} \mathrm{CSF}$, there is a slight decrease in each index. There is no significant anomaly of these values with depth.

\section{Magnetic susceptibility}

Volumetric magnetic susceptibilities were measured using the whole-round core MSCL in all recovered cores from Site C0006 (Fig. F54). Uncorrected magnetic susceptibility values are presented in this volume. Magnetic susceptibility varies between $\sim 0$ and $500 \times 10^{-3}$ SI with a mean of $\sim 200 \times 10^{-3}$ SI. Magnetic susceptibility values in Unit I are relatively low with the exception of a positive spike at $\sim 37 \mathrm{~m}$ CSF. Within Subunit IIA, values generally decrease with depth but oscillations may reflect interbedded sands and clays. Within Subunits IIB and IIC, magnetic susceptibility values are relatively constant with a relatively wide range between $\sim 200$ and $400 \times 10^{-3}$ SI. Values within Subunit IID decrease with depth and are very low through Unit III. These low values may be erroneous because of incomplete core recovery near the bottom of the hole.

\section{Natural gamma ray}

Natural gamma ray (NGR) results are reported in counts per second (cps). The background scatter, produced by Compton scattering, photoelectric absorption, and pair production was measured at the beginning and subtracted from measured gamma ray values. In general, NGR counts are low and consequently may be affected by the short counting interval and porosity variations. The average and standard deviation of NGR results are 34 and $8 \mathrm{cps}$, respectively (Fig. F55). NGR values decrease through Unit I and Subunit IIA, increase with depth in Subunit IIB, and remain relatively constant through Subunits IIC and IID and Unit III where there are no significant anomalies.

\section{Integration with seismic and logging-while-drilling data}

Distances between Holes C0006B, C0006E, and C0006F are $\sim 25 \mathrm{~m}$ and distances between Holes C0006C, C0006E, and C0006D are $2.5 \mathrm{~m}$ (Fig. F2). Core-seismic integration between Holes C0006B, C0006E, and C0006D is primarily based on prestack depth-migrated seismic profiles of Inline 2435 from the Center for Deep Earth Exploration (CDEX) 3-D seismic survey (Fig. F2) and Cross-line 1755 from the Institute for Frontier Research on Earth Evolution (IFREE) 3-D seismic survey. Additionally, the structural and lithologic framework in Hole C0006F relies on Line 89 of the IFREE 3-D seismic survey for correlation. Thick sand layers provide key reflections for correlation. For example, the truncation points indicate an unconformity at the Unit I/Subunit IIA boundary. However, because each of these holes intersects many faults, dips of strata change with depth, complicating correlations. Additionally, between 110 and $210 \mathrm{~m}$ seismic depth below seafloor (SSF) as well as between 330 and 530 m SSF, the seismic phases between holes are discontinuous.

In spite of the low vertical seismic resolution and discontinuous reflectors, core and log data between 
Holes C0006B, C0006E, and C0006F are integrated based on the comparison between NGR, MSCL $P$ wave velocity logs, and gamma ray and sonic logs from LWD data sets (Fig. F56A). Correlations between Holes C0006C, C0006E, and C0006D rely on MSCL NGR and $P$-wave velocity logs (Fig. F56B). The logs are well correlated because these holes are very close to each other. Generally, the estimated uncertainty in correlated depths is $<10 \mathrm{~cm}$. Correlations between Holes C0006E and C0006F have greater uncertainty. Core recovery in Hole C0006F was low, and therefore MSCL-W logs are incomplete for this hole. Furthermore, the LWD sonic log from Hole C0006B is absent at coring intervals of Hole C0006F, and comparison of MSCL-W NGR data and the LWD gamma ray log does not provide a unique solution. As a result of these complications, the correlation between Holes C0006B and C0006F relies to a greater extent on bedding and structural dips interpreted from seismic reflection data; borehole images from the $\mathrm{RAB}$ tool have also been used to correlate data between holes. This proved effective for some thick sand layers that are well matched between Holes C0006E and C00006F.

Depth-shifted profiles are shown in Figure F56 and depth shifts applied to Hole C0006B are given in Table T21. The depth shifts are based on 70 correlations between the five holes. The depth transfer functions were defined by linear regression of the correlated positions. Generally, the depth offsets were $<8 \mathrm{~m}$.

\section{References}

Ashi, J., Kuramoto, S., Morita, S., Tsunogai, U., Goto, S., Kojima, S., Okamoto, T., Ishimura, T., Ijiri, A., Toki, T., Kudo, S., Asai, S., and Utsumi, M., 2002. Structure and cold seep of the Nankai accretionary prism off Kumano-outline of the off Kumano survey during YK01-04 Leg 2 cruise. JAMSTEC J. Deep Sea Res., 20:1-8. (in Japanese, with abstract in English)

Bullard, E.C., 1939. Heat flow in South Africa. Proc. R. Soc. London, Ser. A, 173:474-502.

Fisher, A.T., and Underwood, M.B., 1995. Calibration of an $\mathrm{X}$-ray diffraction method to determine relative mineral abundances in bulk powders using matrix singular value decomposition: a test from the Barbados accretionary complex. In Shipley, T.H., Ogawa, Y., Blum, P., et al., Proc. ODP, Init. Repts., 156: College Station, TX (Ocean Drilling Program), 29-37. doi:10.2973/ odp.proc.ir.156.103.1995

Fuller, M., 1969. Magnetic orientation of borehole cores. Geophysics, 34(5):772-774.

Gradstein, F.M., Ogg, J.G., and Smith, A. (Eds.), 2004. A Geologic Time Scale 2004: Cambridge (Cambridge Univ. Press). http://www.stratigraphy.org/
Hoehler, T.M., 2004. Biological energy requirements as quantitative boundary conditions for life in the subsurface. Geobiology, 2(4):205-215. doi:10.1111/j.14724677.2004.00033.x

Kimura, G., Screaton, E.J., and Curewitz, D., 2007. NanTroSEIZE Stage 1: NanTroSEIZE shallow megasplay and frontal thrusts. IODP Sci. Prosp., 316. doi:10.2204/ iodp.sp.316.2007

Kodama, K.P., 1984. Palaeomagnetism of granitic intrusives from the Precambrian basement under eastern Kansas: orienting drill cores using secondary magnetization components. Geophys. J. R. Astron. Soc., 76:273287.

Lunau, M., Lemke, A., Walther, K., Martens-Habbena, W., and Simon, M., 2005. An improved method for counting bacteria from sediments and turbid environments by epifluorescence microscopy. Environ. Microbiol., 7(7):961-968. doi:10.1111/j.1462-2920.2005.00767.x

Moore, G.F., Taira, A., Klaus, A., Becker, L., Boeckel, B., Cragg, B.A., Dean, A., Fergusson, C.L., Henry, P., Hirano, S., Hisamitsu, T., Hunze, S., Kastner, M., Maltman, A.J., Morgan, J.K., Murakami, Y., Saffer, D.M., SánchezGómez, M., Screaton, E.J., Smith, D.C., Spivack, A.J., Steurer, J., Tobin, H.J., Ujiie, K., Underwood, M.B., and Wilson, M., 2001. New insights into deformation and fluid flow processes in the Nankai Trough accretionary prism: results of Ocean Drilling Program Leg 190. Geochem., Geophys., Geosyst., 2(10):1058. doi:10.1029/ 2001GC000166

Moore, J.C., and Karig, D.E., 1976. Sedimentology, structural geology, and tectonics of the Shikoku subduction zone, southwestern Japan. Geol. Soc. Am. Bull., 87(9):1259-1268. doi:10.1130/ 0016-7606(1976)87<1259:SSGATO>2.0.CO;2

Parkes, R.J., Cragg, B.A., and Wellsbury, P., 2000. Recent studies on bacterial populations and processes in subseafloor sediments: a review. Hydrogeol. J., 8(1):11-28. doi:10.1007/PL00010971

Reeburgh, W.S., 1976. Methane consumption in Cariaco Trench waters and sediments. Earth Planet. Sci. Lett., 28(3):337-344. doi:10.1016/0012-821X(76)90195-3

Shibuya, H., Merrill, D.L., Hsu, V., and Leg 124 Shipboard Scientific Party, 1991. Paleogene counterclockwise rotation of the Celebes Sea-orientation of ODP cores utilizing the secondary magnetization. In Silver, E.A., Rangin, C., von Breymann, M.T., et al., Proc. ODP, Sci. Results, 124: College Station, TX (Ocean Drilling Program), 519523. doi:10.2973/odp.proc.sr.124.169.1991

Shipboard Scientific Party, 2001a. Site 1173. In Moore, G.F., Taira, A., Klaus, A., et al., Proc. ODP, Init. Repts., 190: College Station, TX (Ocean Drilling Program), 1-147. doi:10.2973/odp.proc.ir.190.104.2001

Shipboard Scientific Party, 2001b. Site 1174. In Moore, G., Taira, A., Klaus, A., et al., Proc. ODP, Init. Repts., 190: College Station, TX (Ocean Drilling Program), 1-149. doi:10.2973/odp.proc.ir.190.105.2001

Sloan, E.D., 1998. Clathrate Hydrates of Natural Gases (2nd ed.): New York (Marcel Dekker). 
Su, X., 1996. Development of late Tertiary and Quaternary coccolith assemblages in the northeast Atlantic. GEOMAR Rep., 48.

Ujiie, K., Maltman, A.J., and Sánchez-Gómez, M., 2004. Origin of deformation bands in argillaceous sediments at the toe of the Nankai accretionary prism, southwest Japan. J. Struct. Geol., 26(2):221-231. doi:10.1016/ j.jsg.2003.06.001
Yamano, M., Kinoshita, M., Goto, S., and Matsubayashi, O., 2003. Extremely high heat flow anomaly in the middle part of the Nankai Trough. Phys. Chem. Earth, 28(911):487-497. doi:10.1016/S1474-7065(03)00068-8

Publication: 11 March 2009 MS 314315316-134 
Figure F1. Hole locations, Sites C0006 and C0007.

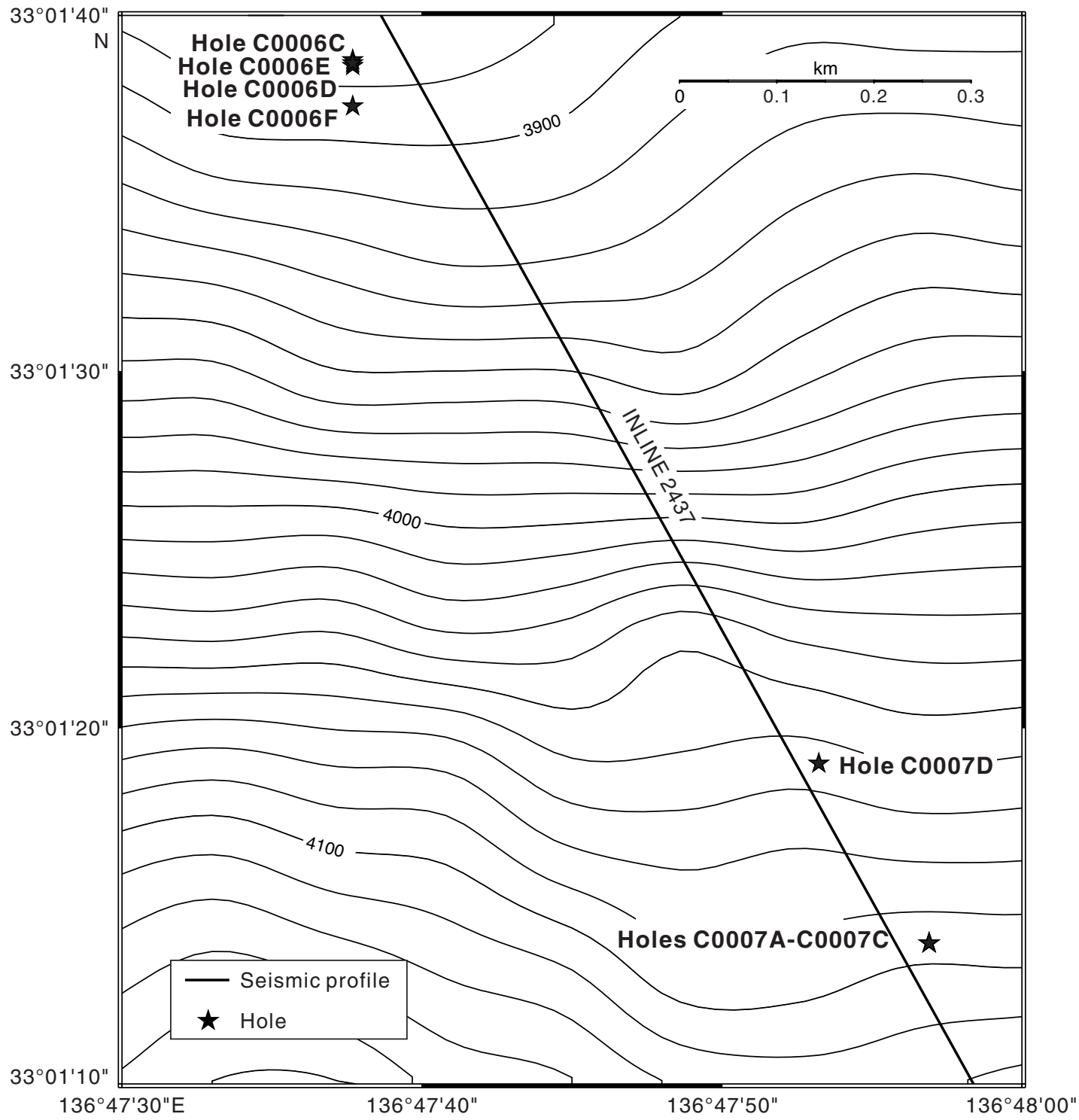




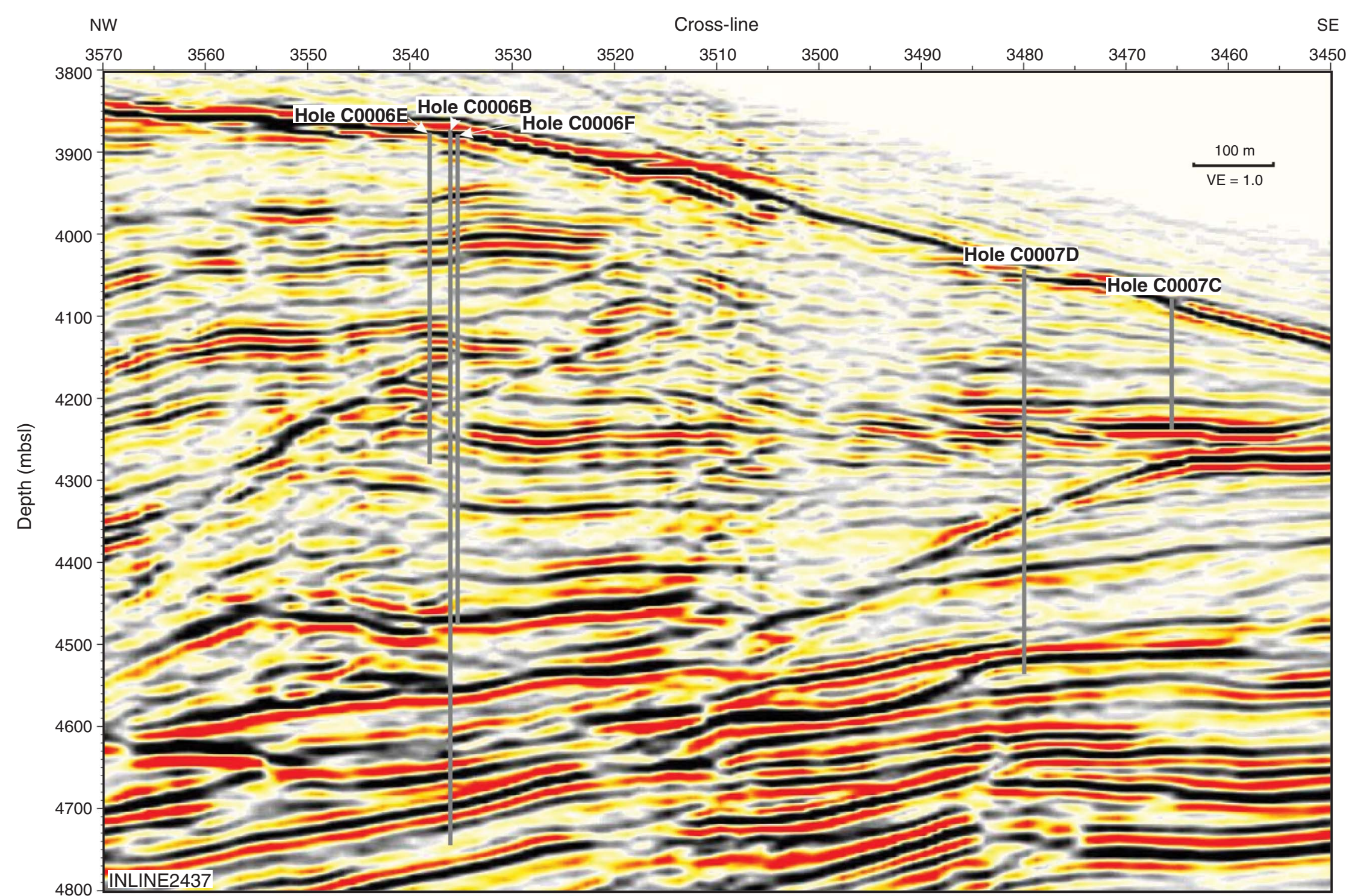


Figure F3. Core recovery and sand and silt distribution, Site C0006. A. Core recovery and lithologic units. CSF $=$ core depth below seafloor. LWD = logging-while-drilling. (Continued on next page.)

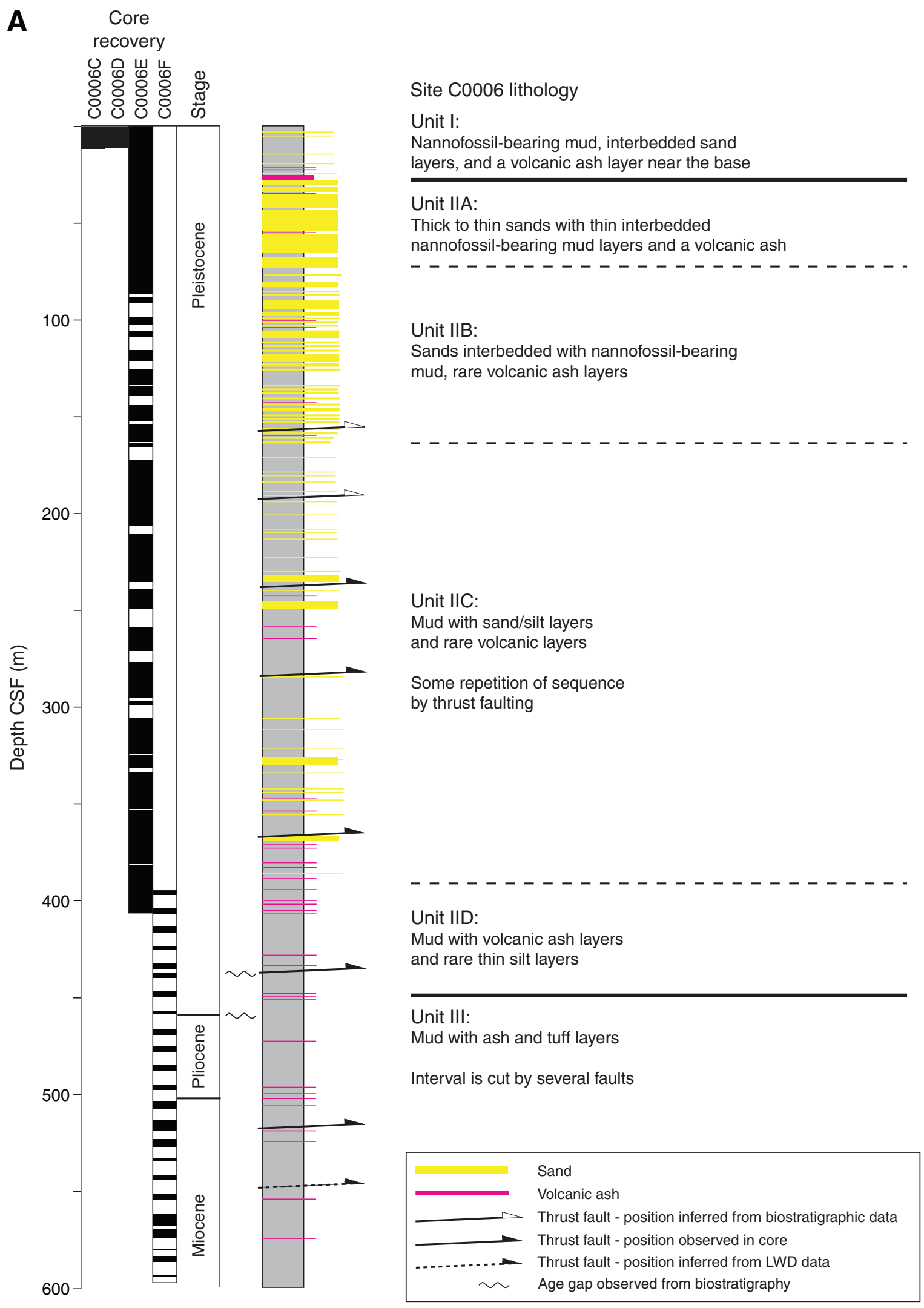


Figure F3 (continued). B. Distribution of sand and silt.

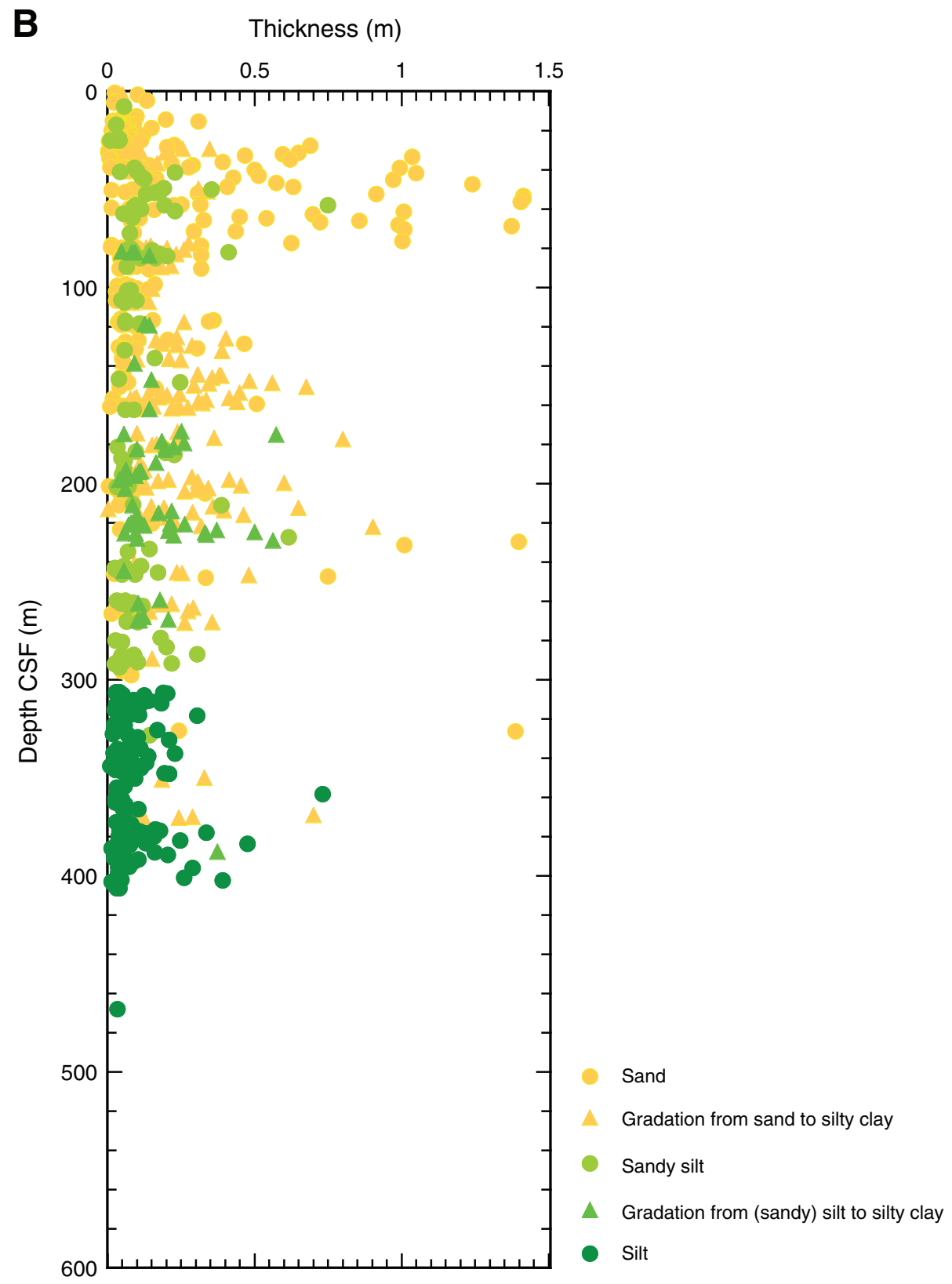


Figure F4. XRD data, Holes C0006E and C0006F. CSF = core depth below seafloor. WR = whole round.

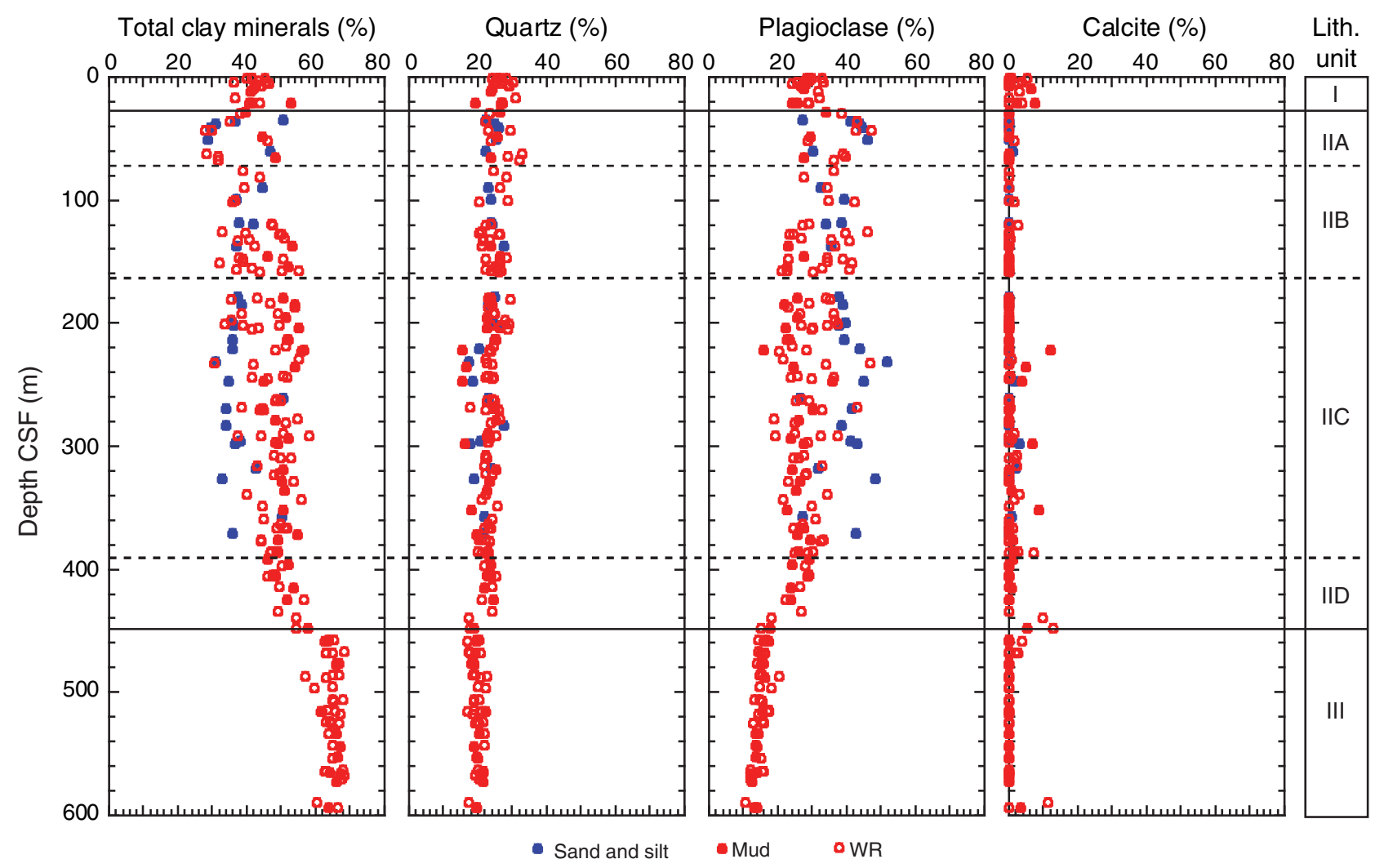


Figure F5. Core photographs, Units I and II. A. Greenish gray clay with normal fault, Unit I (interval 316C0006E-3H-2, 40-68 cm). B. Thick soupy sand beds separated by ash, Subunit IIA (interval 316-C0006E-7H-1, 10-64 cm). C. Graded sands with indistinct upper boundaries, Subunit IIB (interval 316-C0006E-15X-1, 44$84 \mathrm{~cm})$.

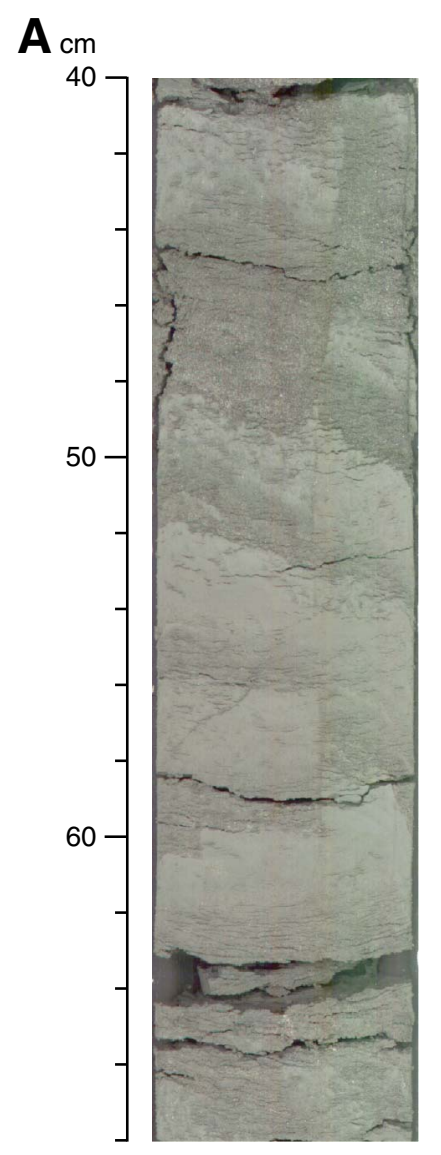

$\mathbf{B} \mathrm{cm}$

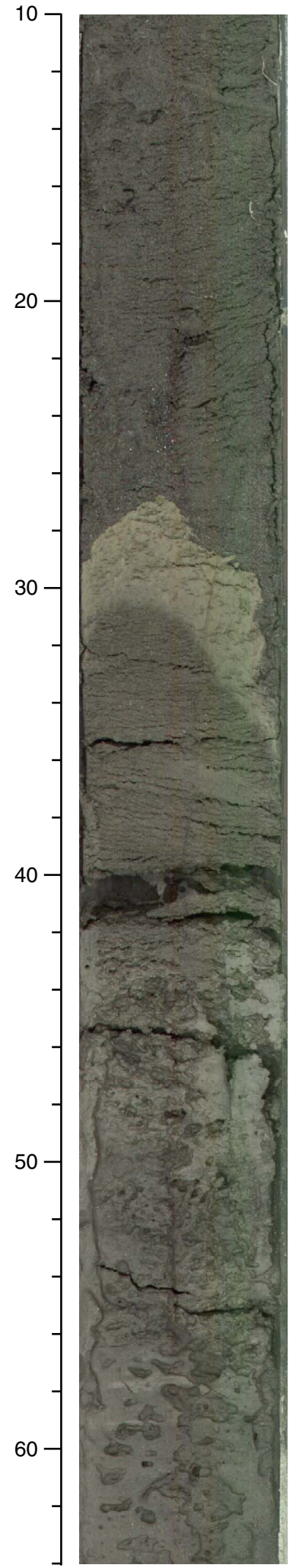

C cm

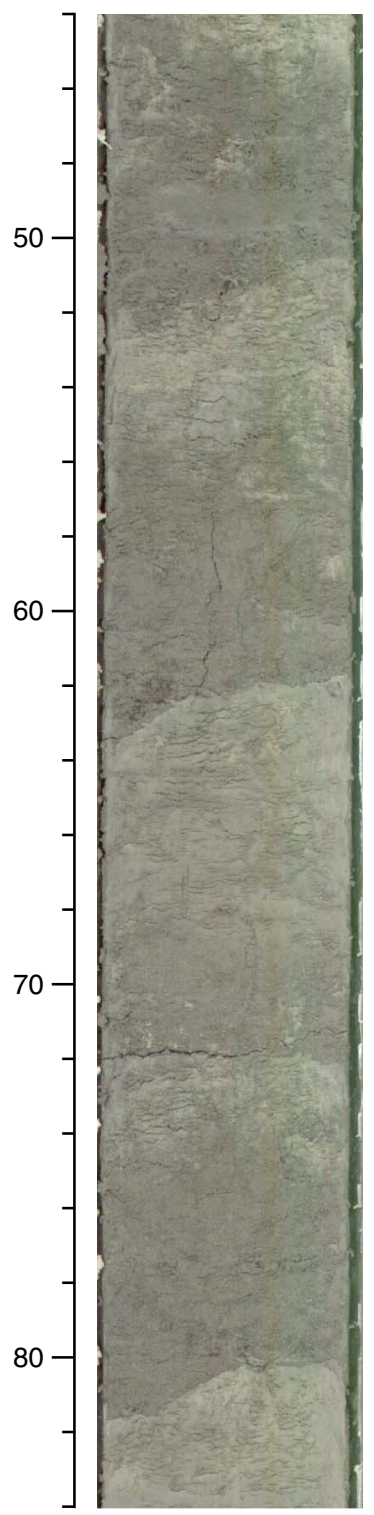


Figure F6. Core photographs, Subunits IIC and IID. A. Wood-bearing turbidite sand (interval 316-C0006E-45X7, 60-98 cm). B. Wood fragment (Section 316-C0006E-45X-7, $37 \mathrm{~cm}$ ). C. Greenish gray claystone from Subunit IID (interval 316-C0006F-5R-1, 48-74 cm).
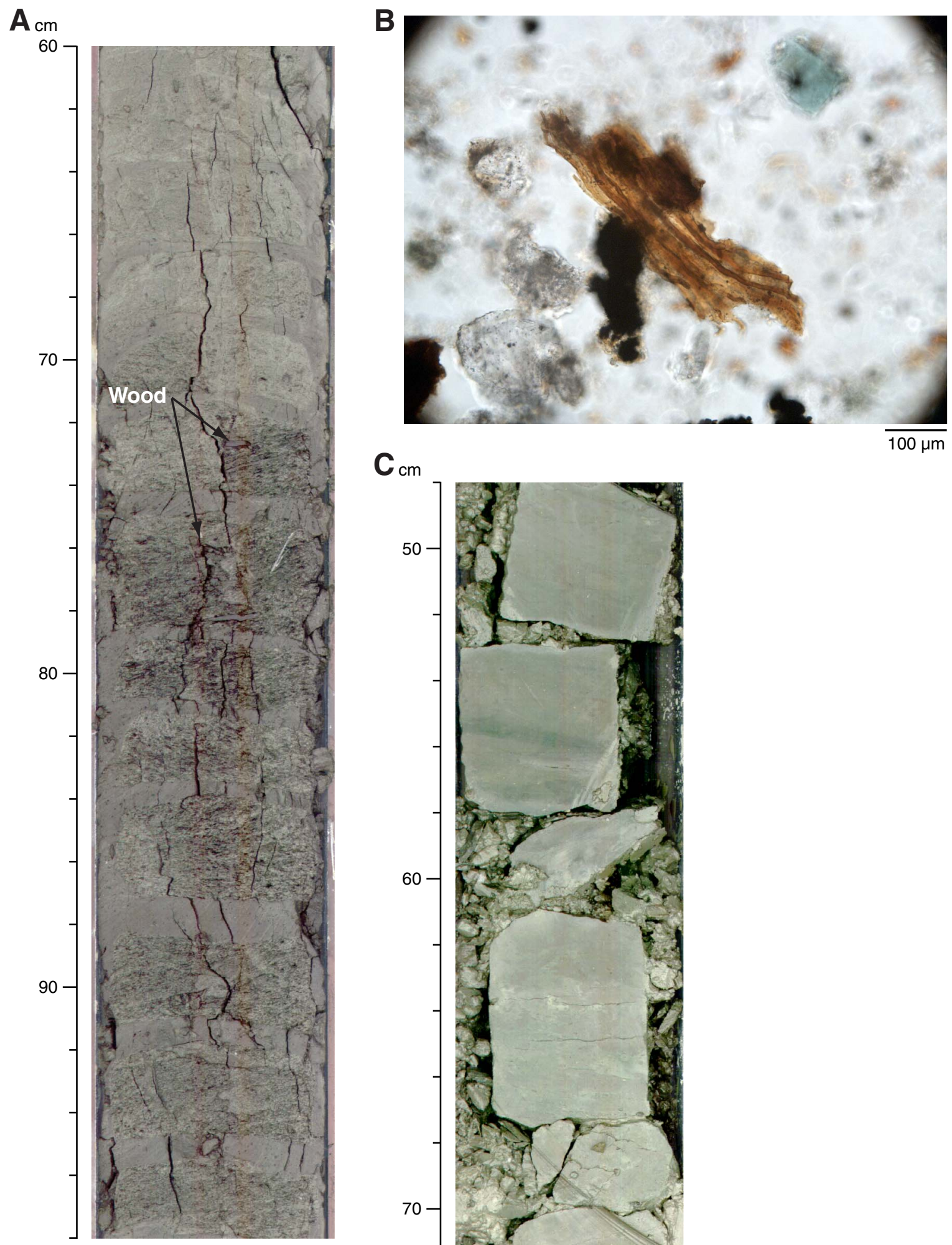

$\mathbf{C}_{\mathrm{cm}}$

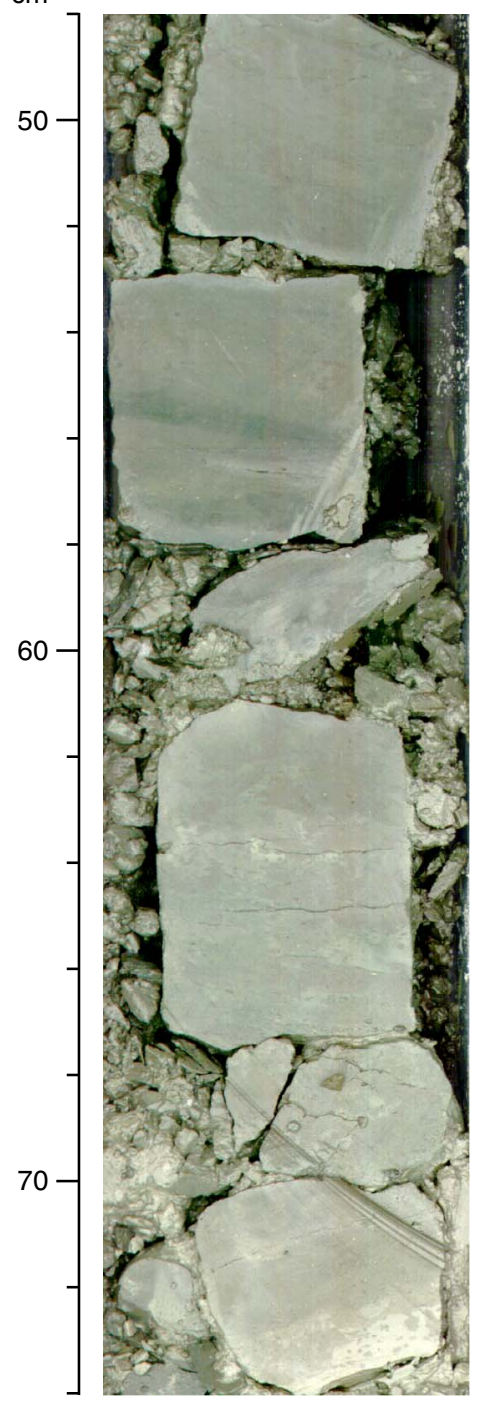


Figure F7. Occurrence of ash, Site C0006. A. Distribution and thickness of volcanic ash layers. B. Glass shards in ash layer (Section 316-C0006E-42X-8, $90 \mathrm{~cm}$ ). C. Lamination in dolomitized ash (Section 316-C0006E-47X-1, $4 \mathrm{~cm}$ ). D. Carbonate-cemented ash with bioturbated top (interval 316-C0006F-12R-1, 12-25 cm). CSF $=$ core depth below seafloor.
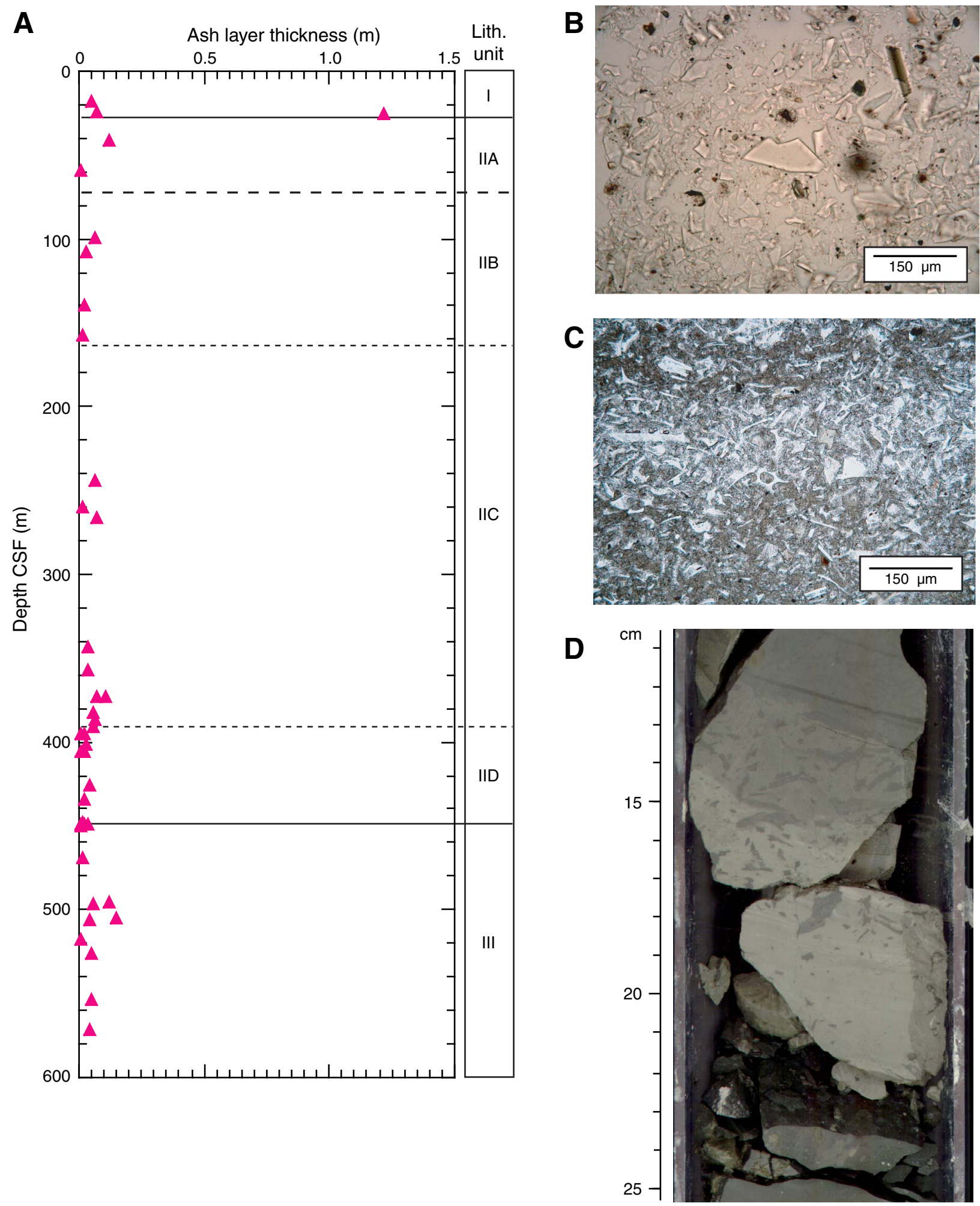
Figure F8. XRF phosphorous, Subunits IIB, IIC, and IID. CSF = core depth below seafloor.

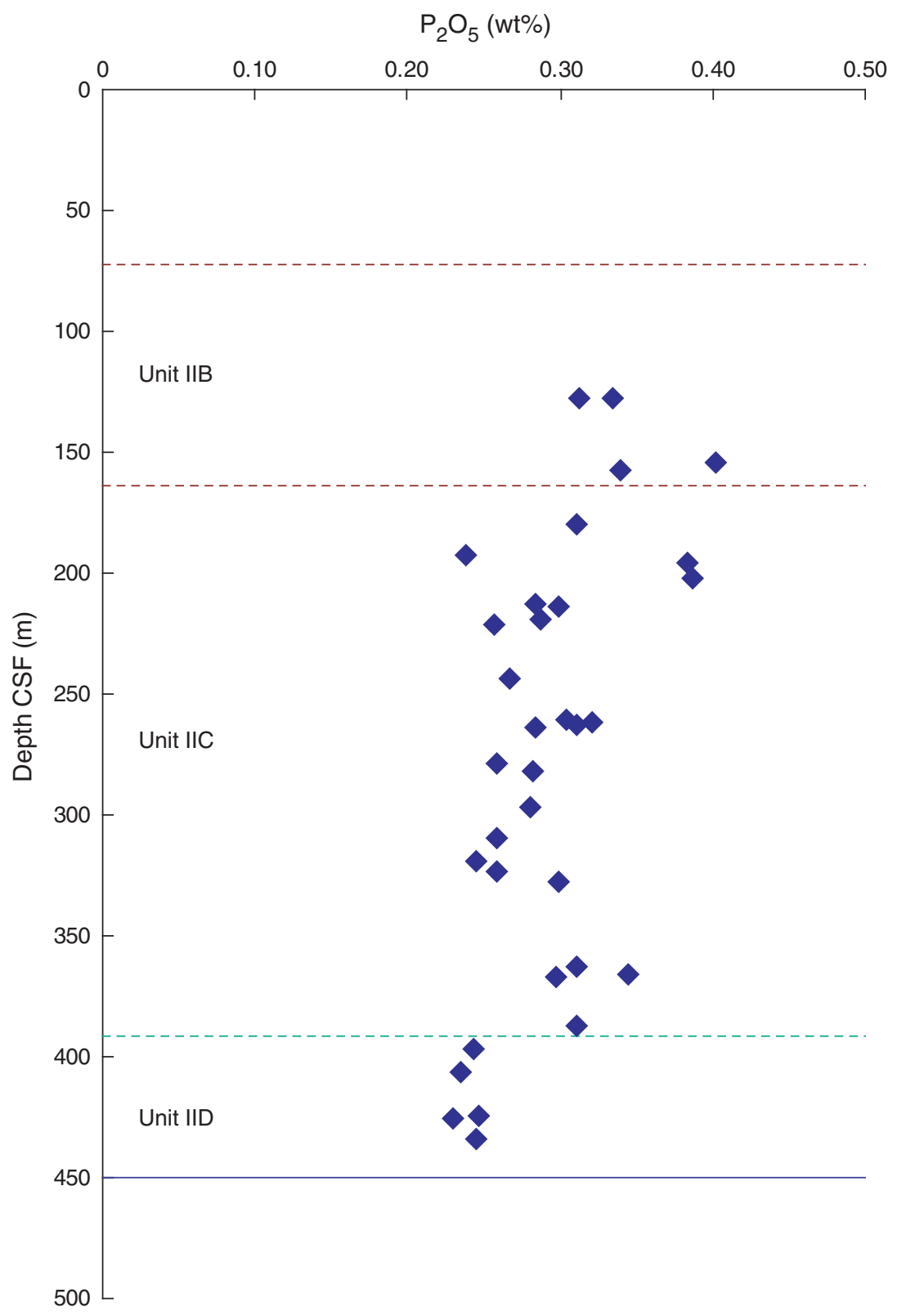


Figure F9. Core photographs of typical appearance of mudstone lithologies, Unit III. A. Bioturbated greenish gray claystone with abundant Zoophycos burrows (interval 316-C0006F-11R-1, 15-28 cm). B. Gray claystone with small fault and possible vein structures(?) (interval 316-C0006F-19R-1, 80-104 cm).

$\mathbf{A}_{\mathrm{cm}}$

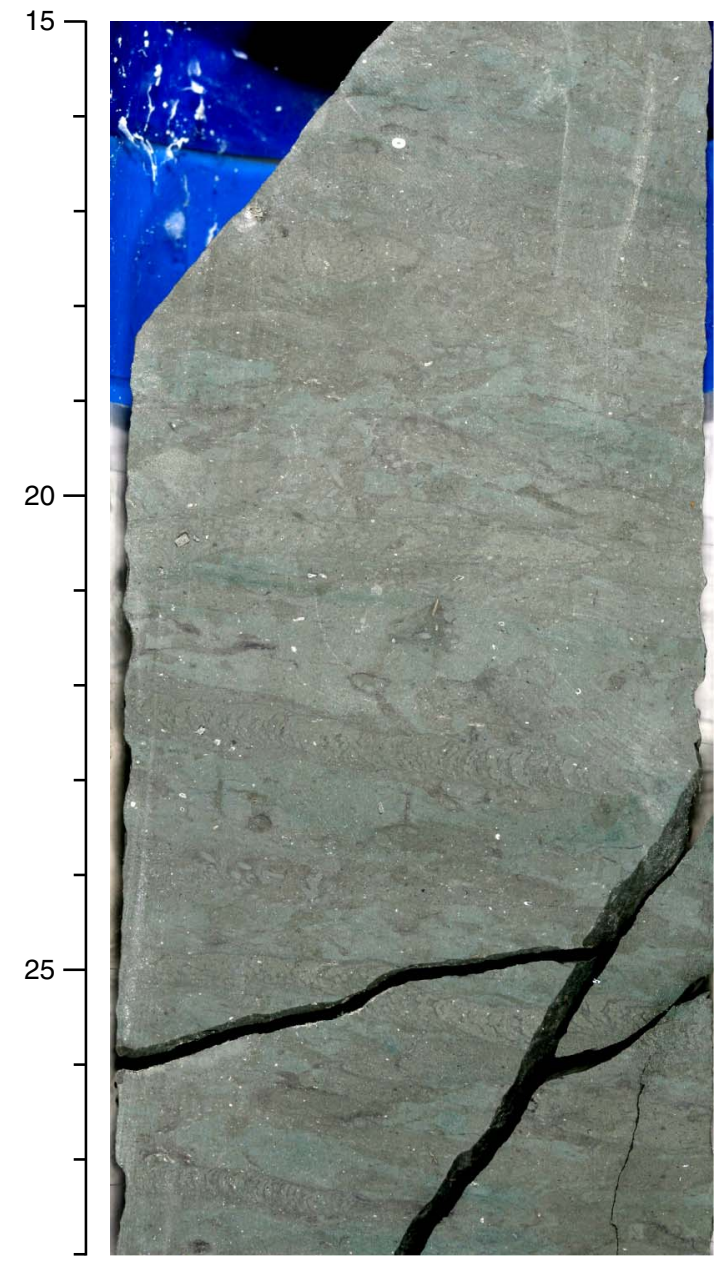

$\mathbf{B}_{\mathrm{cm}}$

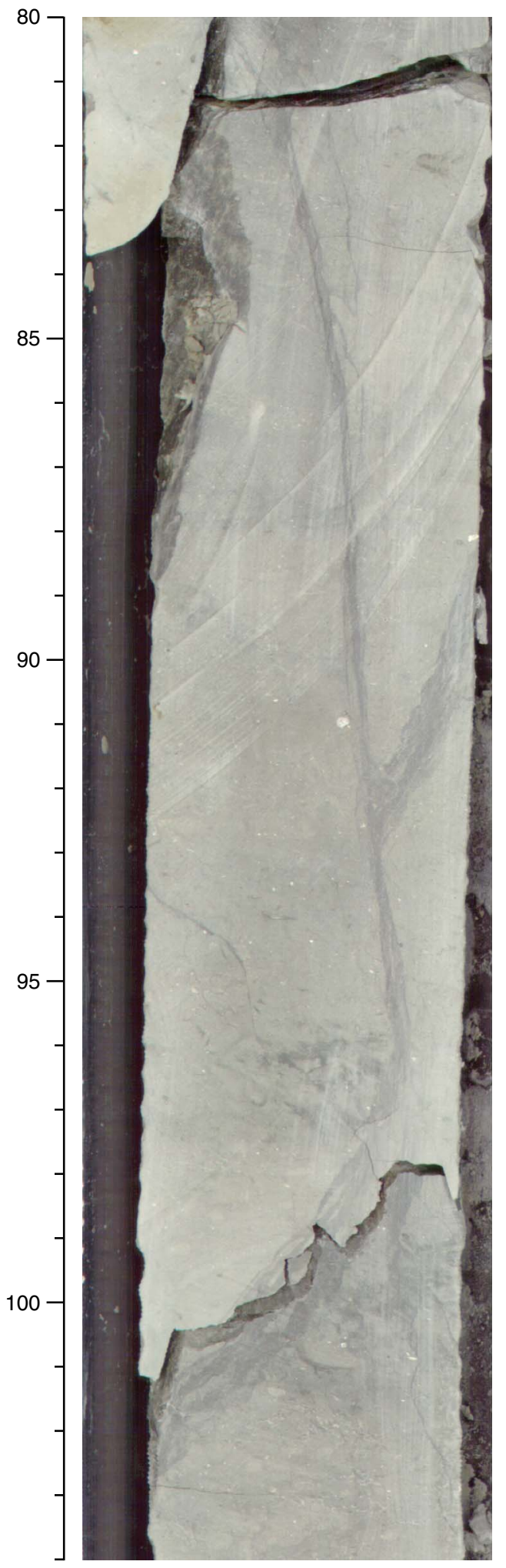


Figure F10. Photomicrograph of possible phillipsite (arrows) observed in a smear slide (Section 316-C0006F$19 \mathrm{R}-1,119 \mathrm{~cm})$.

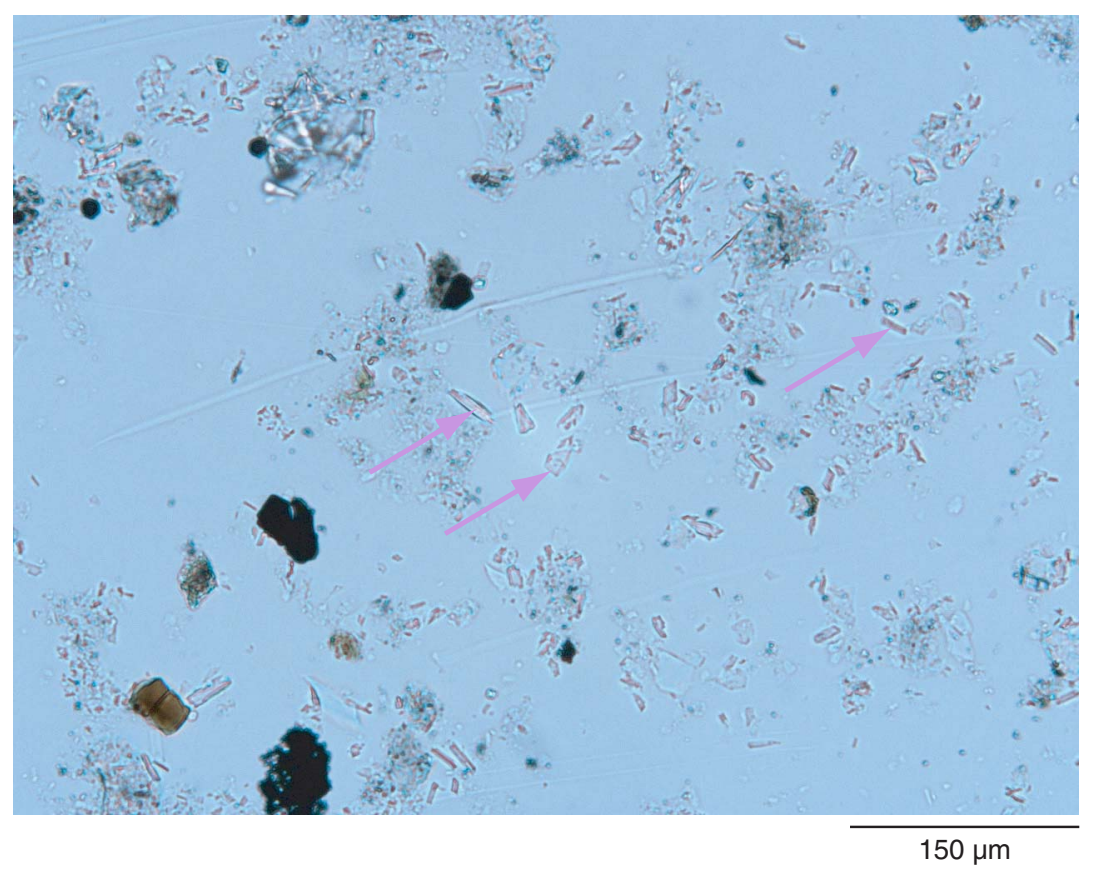


Figure F11. Computed tomography (CT) number vs. depth, Holes C0006C and C0006D. Average value for each core obtained from $\sim 70$ measurements with a 4-10 cm interval. CSF = core depth below seafloor. Orange and red dots $=$ averages for intervals .

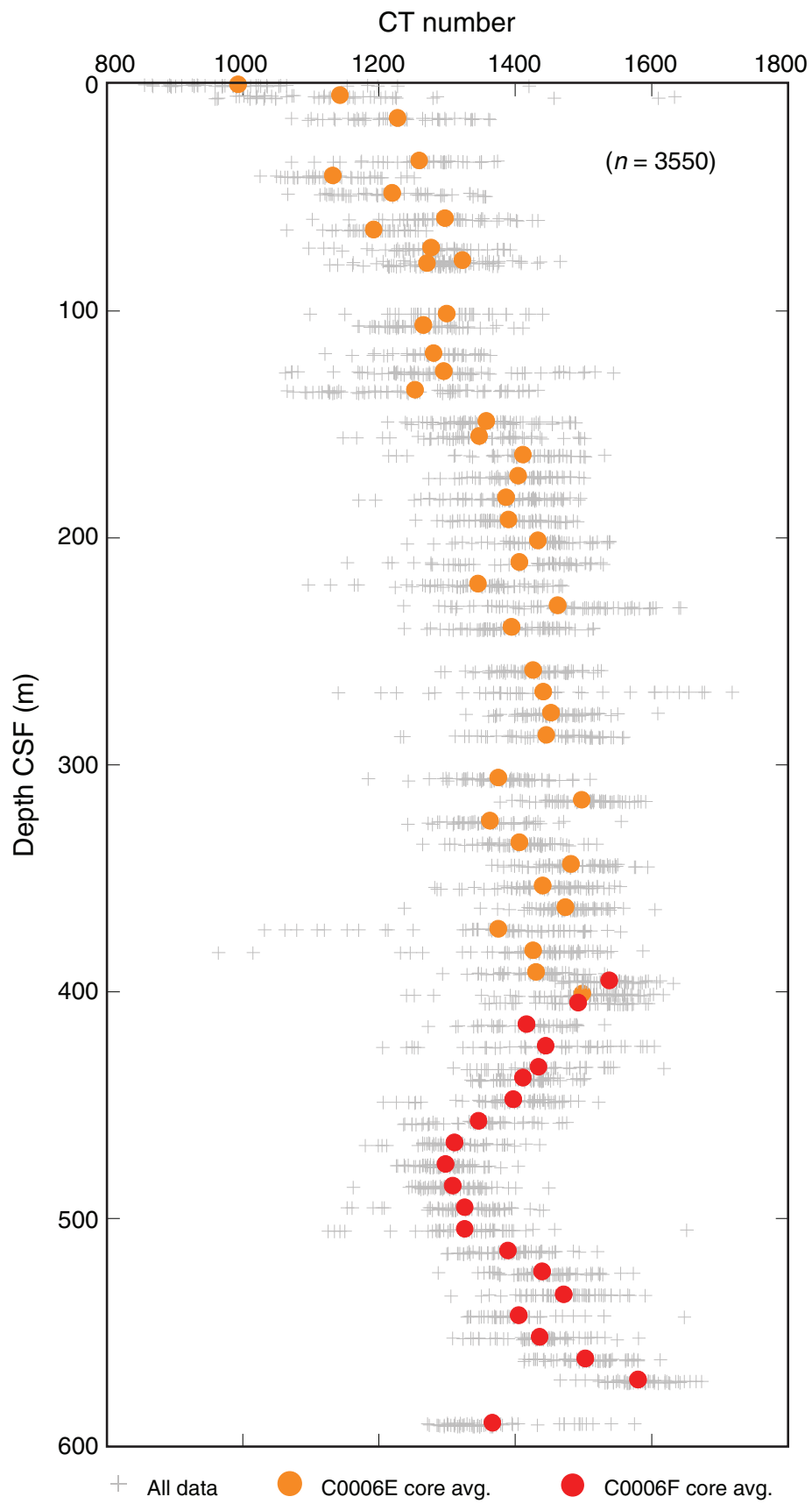


Figure F12. Structural observations with distribution and dip angle of bedding, fissility and fault surfaces, and deformation bands vs. depth, Site C0006. Black horizontal lines = intervals of concentrated deformation (probable faults) identified on the basis of multiple lines of evidence (see the "Expedition 316 methods" chapter). CSF = core depth below seafloor. LWD = logging-while-drilling.

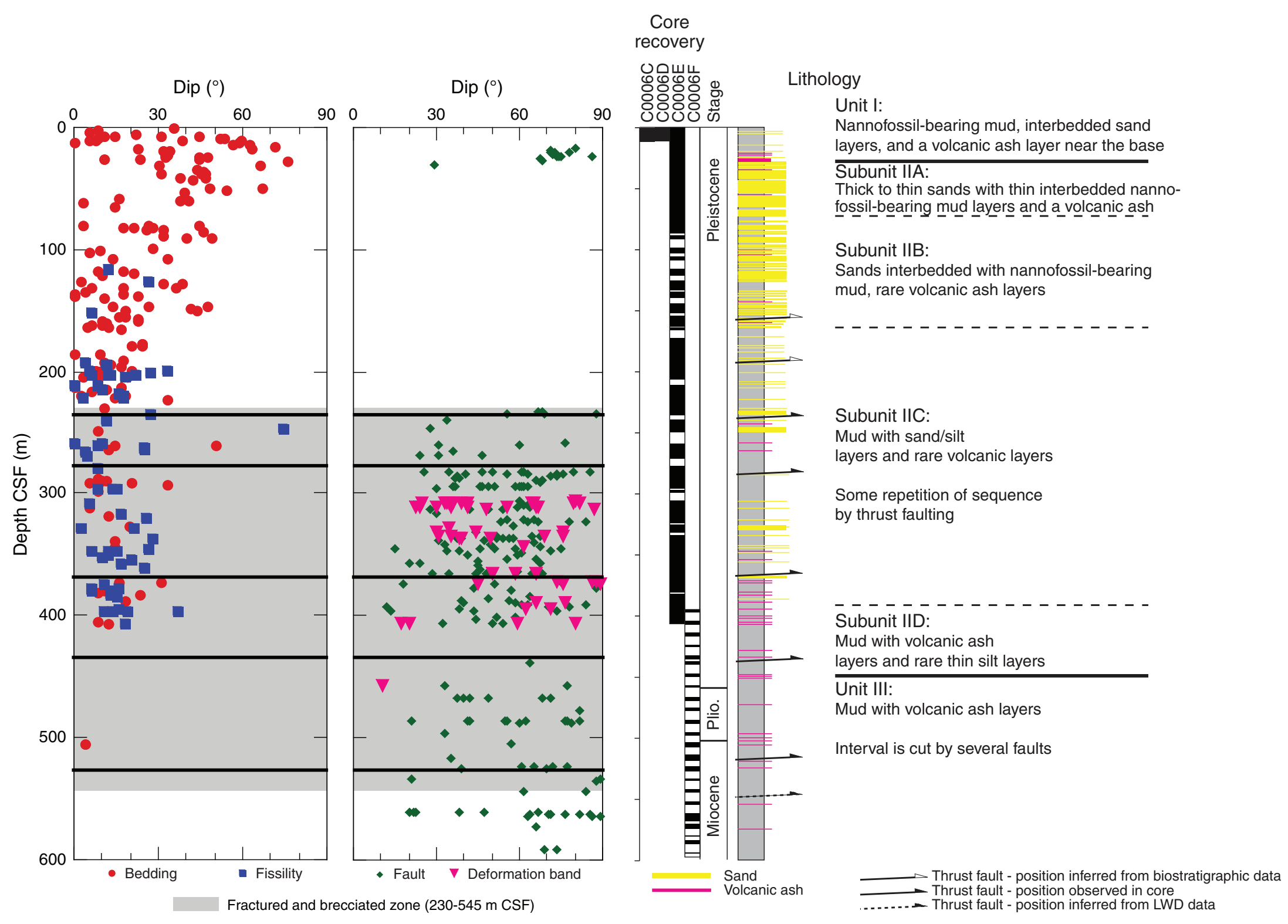




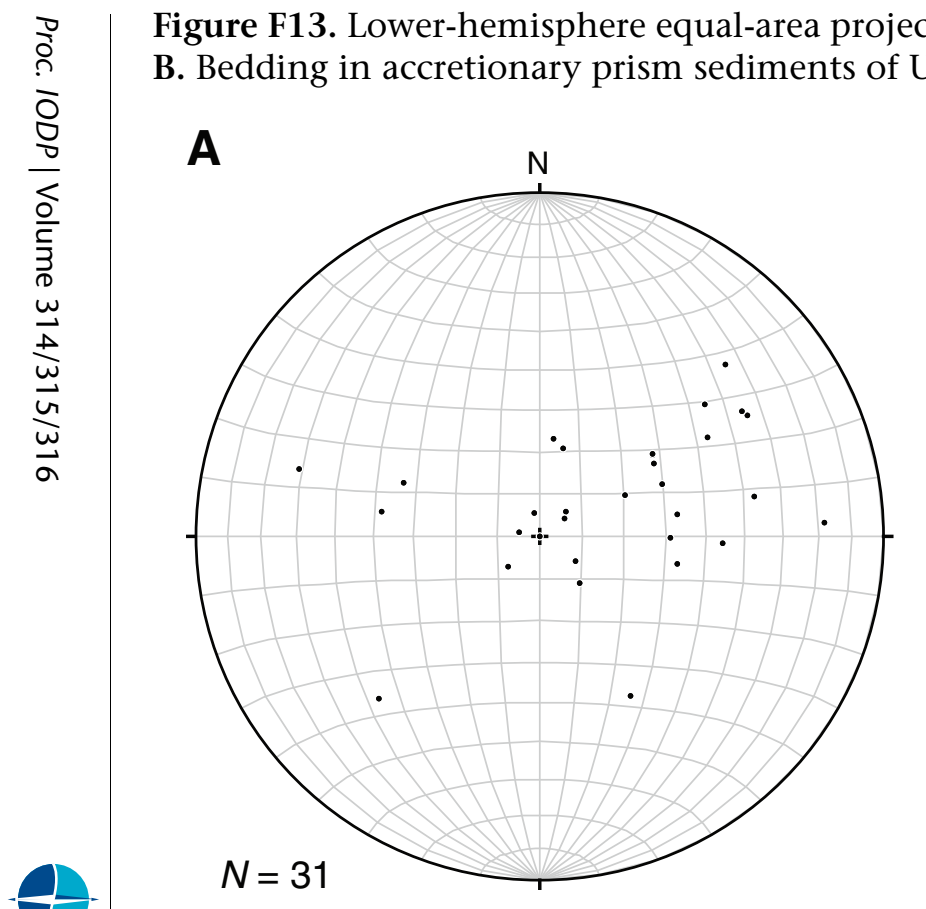

Figure F13. Lower-hemisphere equal-area projections of poles to bedding and fissility, Holes C0006E and C0006F. A. Bedding in lithologic Unit I. B. Bedding in accretionary prism sediments of Unit II. C. Fissility in accretionary prism sediments of Unit II.

A

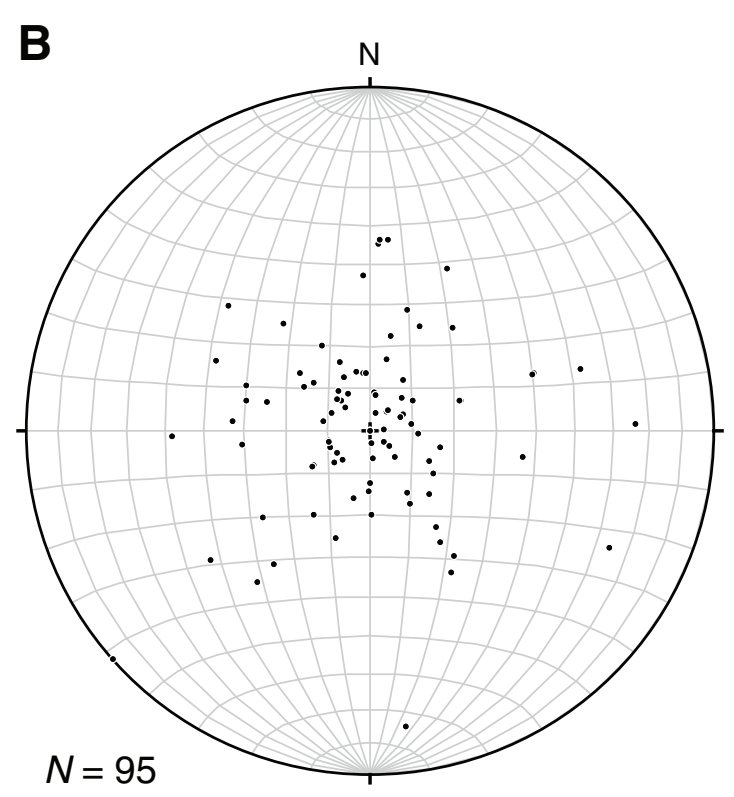

C

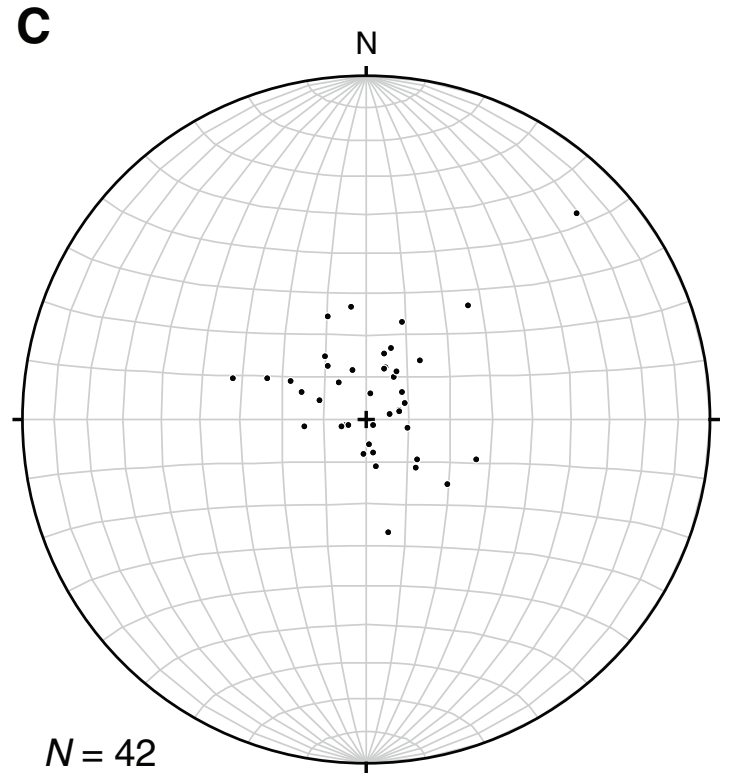


Figure F14. Photographs of normal faults in lithologic Unit I (trench to slope transition sediments). A. Interval 316-C0006E-3H-9, 44-70 cm. B. Interval 316-C0006E-3H-9, 110-137 cm. Half arrows = sense of shear.

$\mathbf{A}_{\mathrm{cm}}$

$$
\text { - }
$$

$\mathbf{B} \mathrm{cm}$

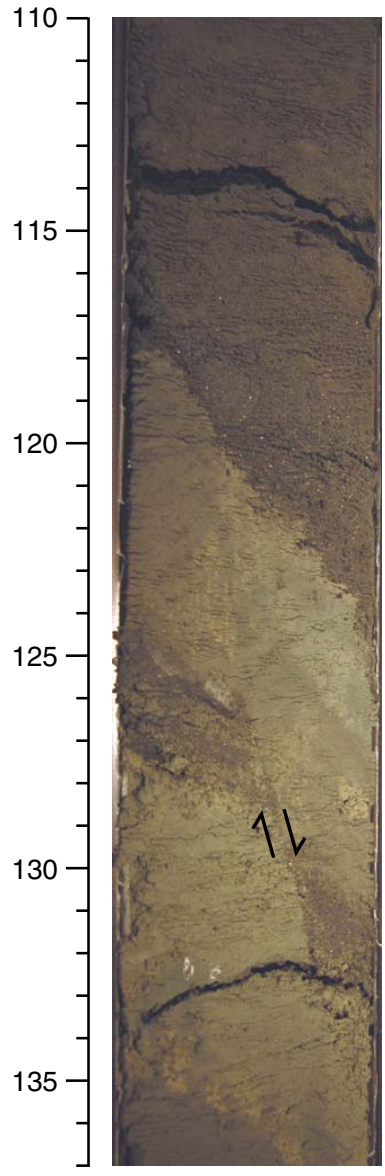


Figure F15. Core photographs and corresponding CT images of heterogeneously fractured or brecciated intervals in the upper part of the fractured/brecciated zone. A. Intervals 316-C0006E-39X-1 and 39X-2. B. Close-up of breccia (interval 316-C0006E-39X-1, 24-43 cm). On the CT image (right side), intervals appearing as nonfractured correspond to drilling mud and fragments injected between more coherent pieces during drilling (biscuiting).
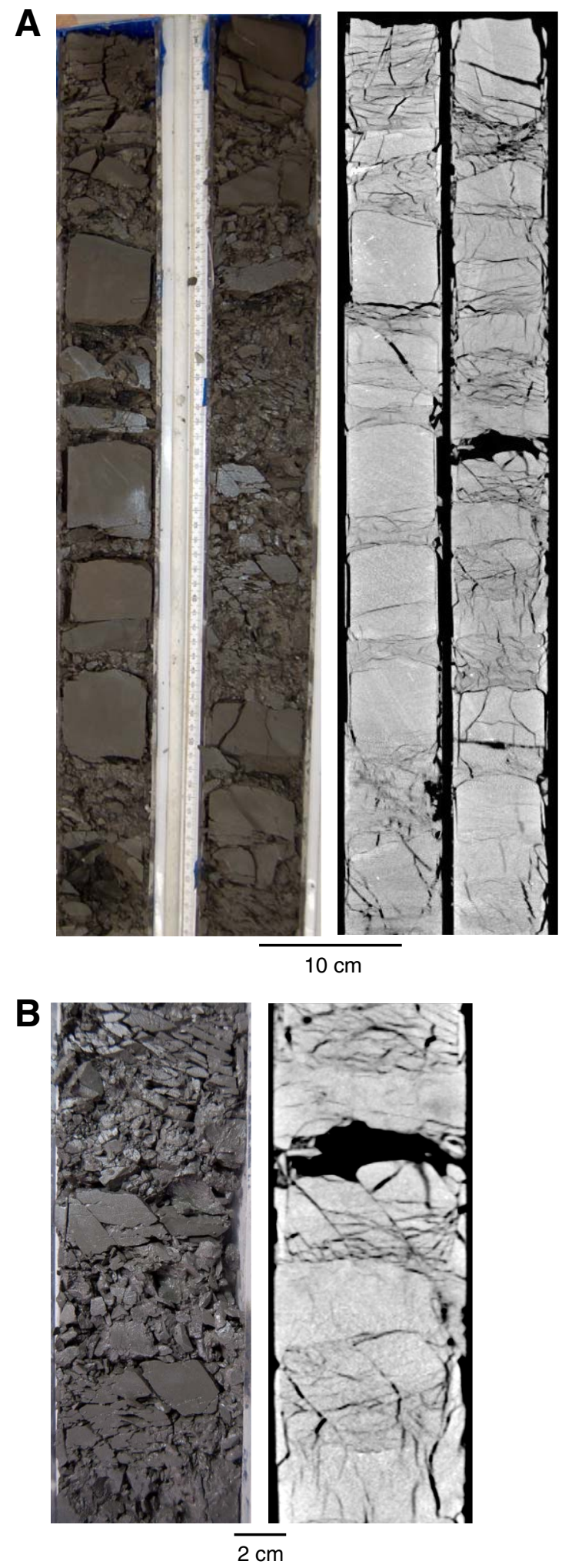
Figure F16. CT cross-sectional images of a normal fault (interval 316-C0006F-15R-1, 63-83 cm). A. View perpendicular to core axis. B. View along the core axis. C. Thick slice CT image viewed parallel to strike of the fault; colored lines identify three correlative high CT number markers offset along the fault surface. Sense of shear is normal, and displacement is $\sim 1 \mathrm{~cm}$. With a correction based on paleomagnetic data, normal fault is oriented $068^{\circ}, 78^{\circ}$ northwest. Fault is located just above zone of tectonic breccia located at 533-543 m CSF in Hole C0006F. Half arrows $=$ sense of shear.

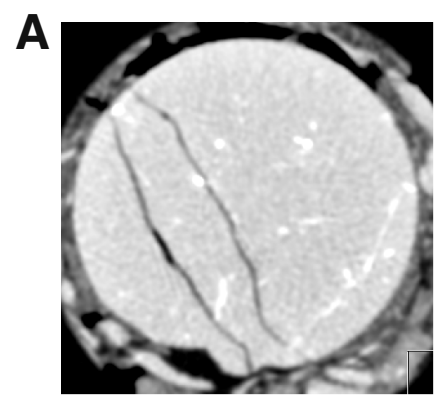

\section{B}

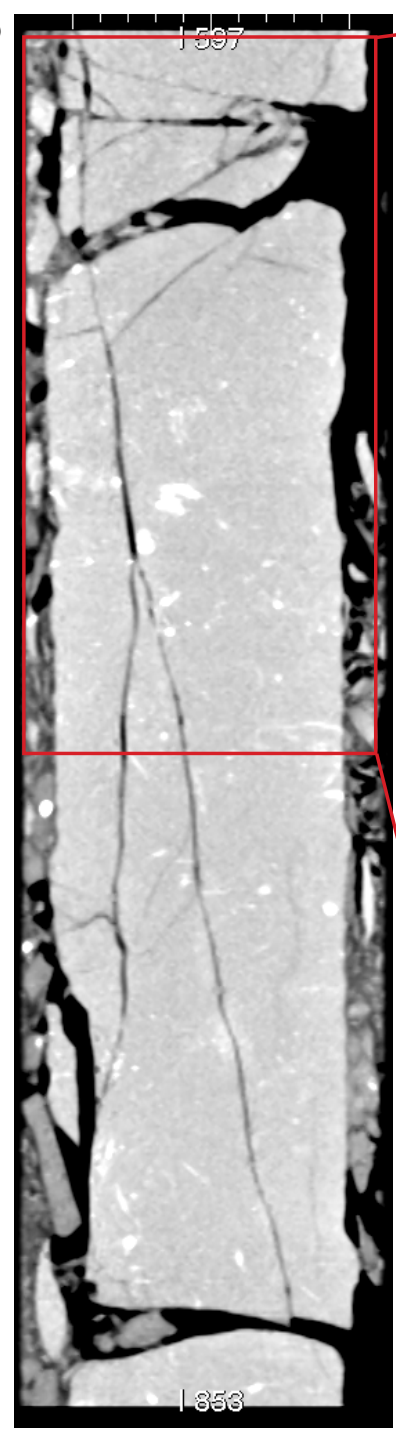

C

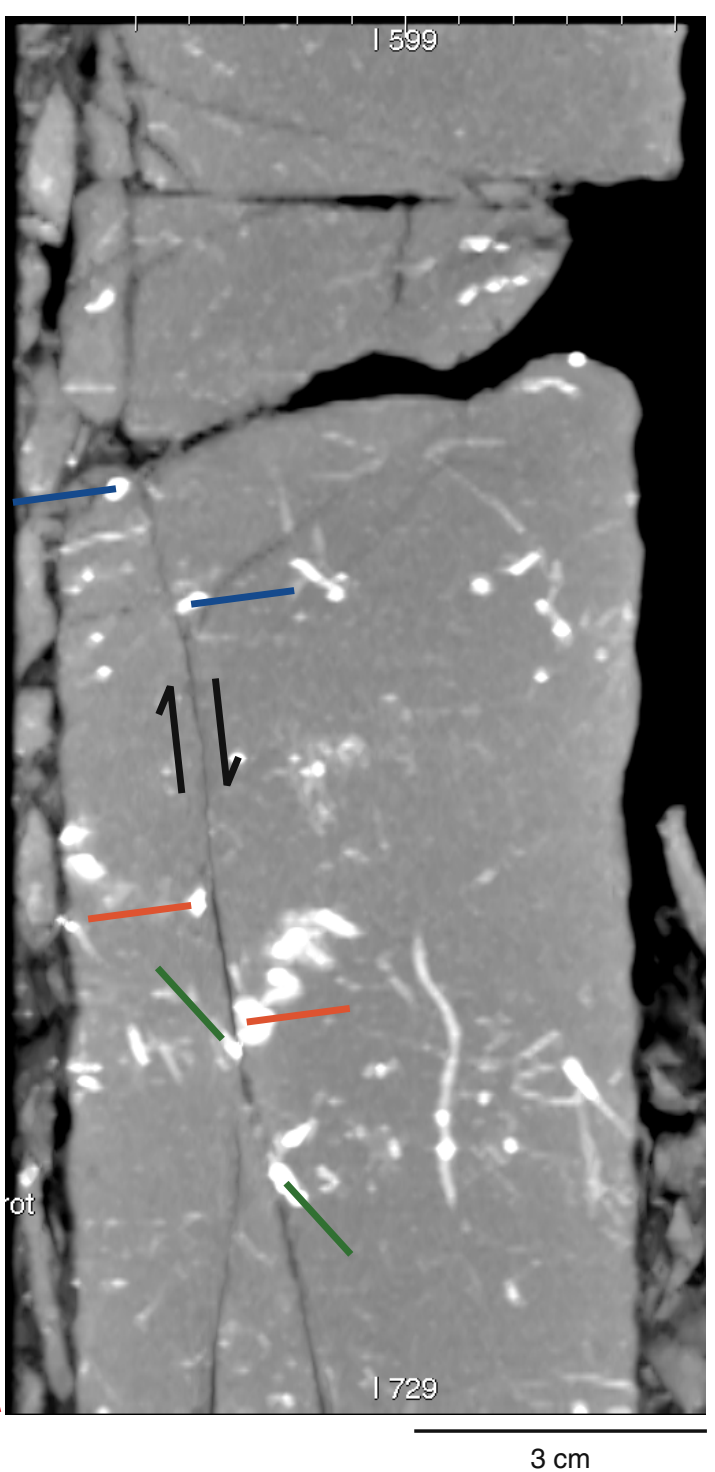


Figure F17. Lower-hemisphere equal-area projections of all faults from the fractured/brecciated zone, showing the heterogeneity of the data set.

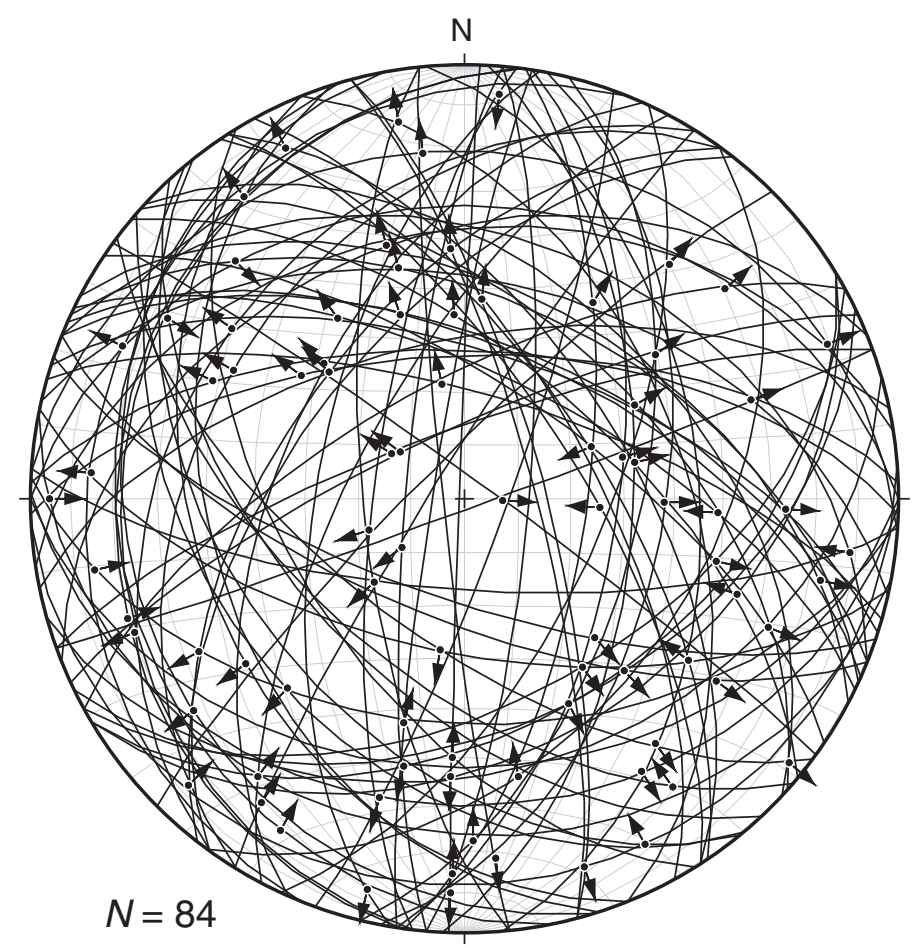


Figure F18. A. CT image of a tectonic joint viewed along the core axis and perpendicular to strike. B. Photograph of the joint surface (interval 316-C0006F-18R-1, 89-102 cm). Macroscopic planarity of joint and plumose structures on the surface attest to mode-I opening. With a correction based on paleomagnetic data, the joint is oriented vertical and strikes $155^{\circ}$. The joint is located just below the zone of tectonic breccia located at 533$543 \mathrm{~m}$ CSF in Hole C0006F.

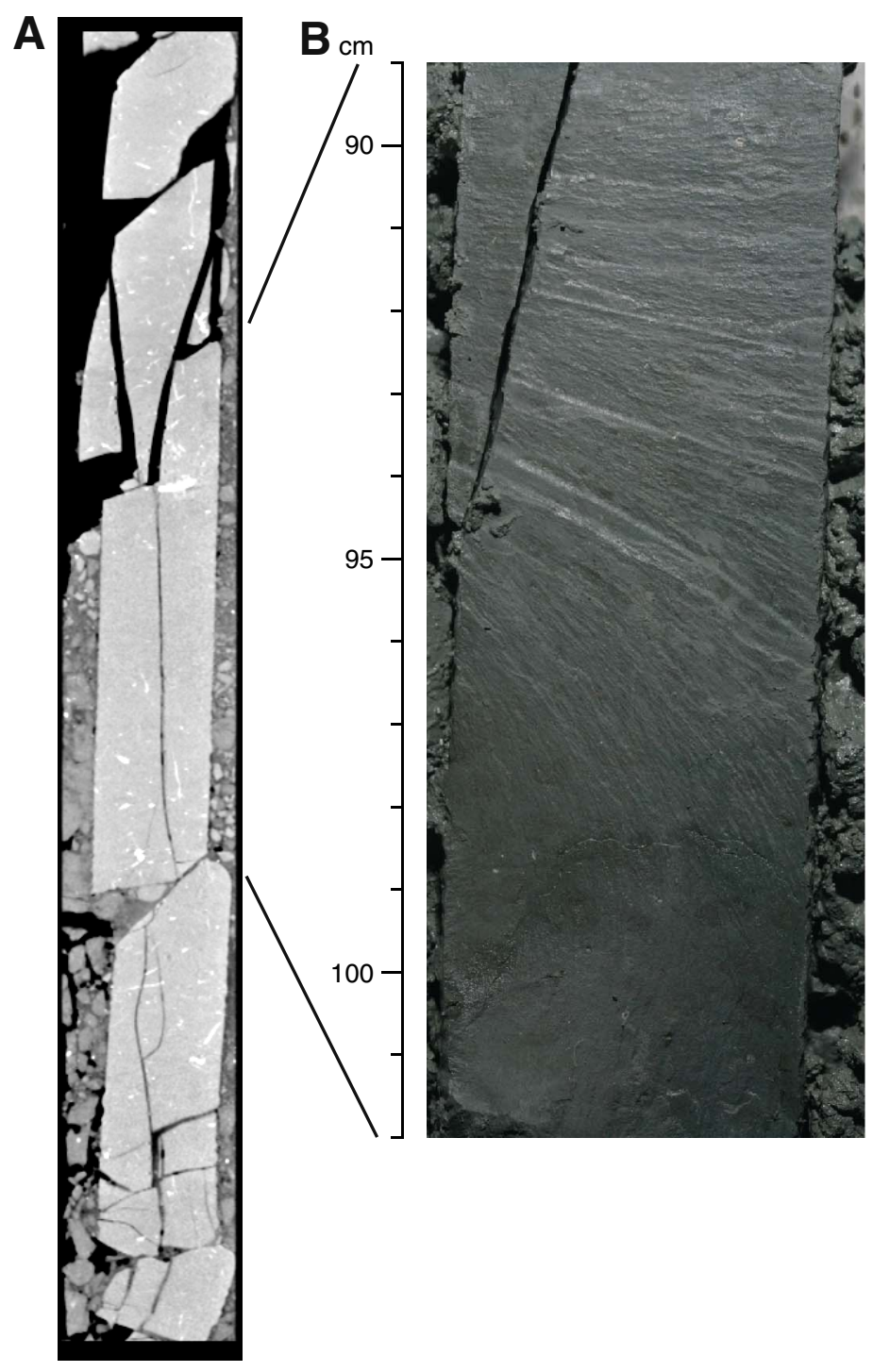


Figure F19. Typical aspects of deformation bands. A. Deformation bands showing two oppositely dipping sets (interval 316-C0006E-42X-1, 108-116 cm). B. Deformation bands showing kinklike aspect or bifurcation into twin strands (interval 316-C0006E-40X-1, 37-46 cm). C. Sediment-filled veins displaced with a reverse sense by deformation bands (interval 316-C0006-41X-6, 105-109 cm). Half arrows = sense of shear, broken lines = black seams deflected by the deformation band showing a reverse sense of shear.

A

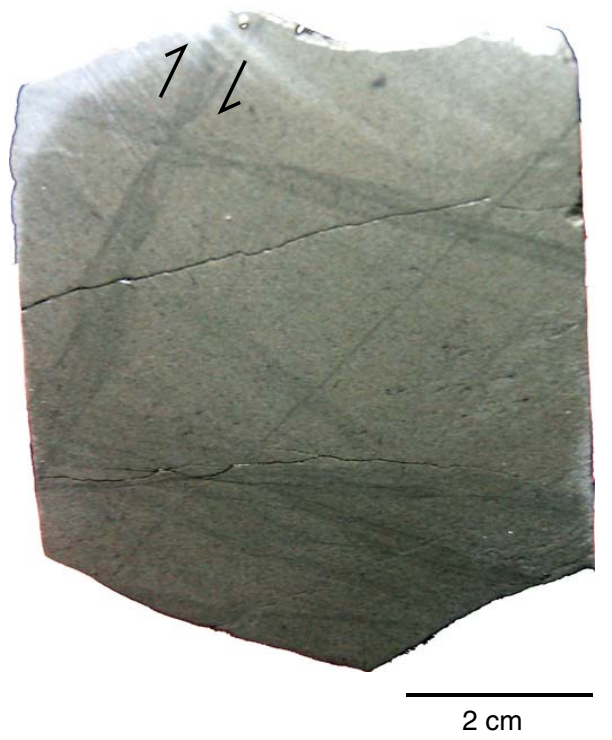

B

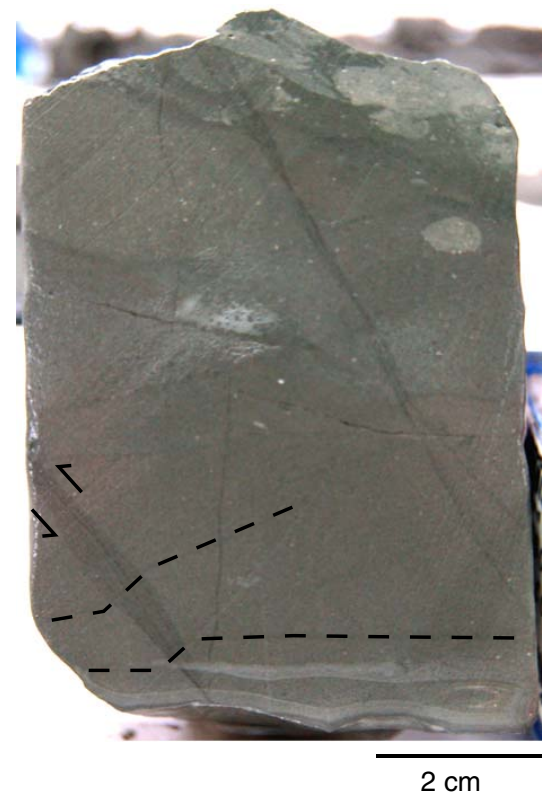

C

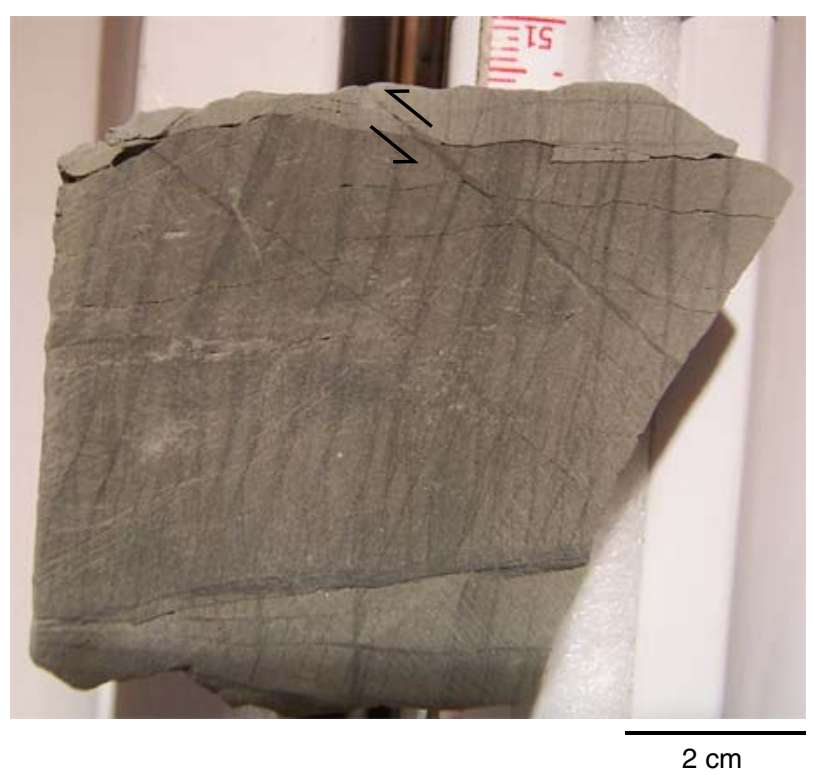


Figure F20. Lower-hemisphere equal-area projection of deformation bands after paleomagnetic correction. A. Poles to surfaces of deformation bands. B. Average of two sets of deformation bands with the plane bisecting the obtuse dihedral angle.
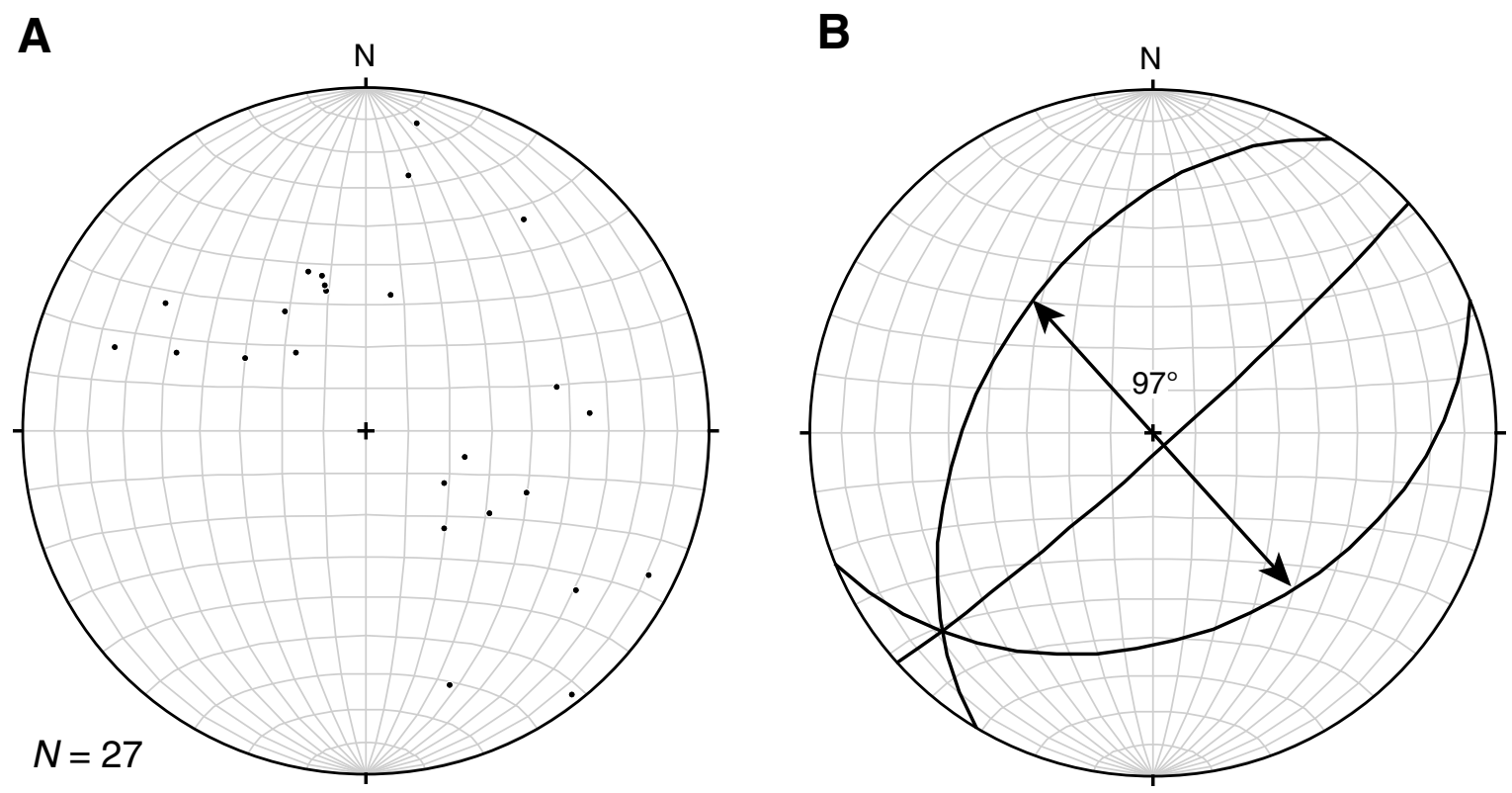
Figure F21. Variation in density of deformation bands with depth in Hole C0006E (150-400 mbsf interval) determined from CT scan images. Linear density determined by counting total number of bands in each core section and dividing by section length for a total of 44 sections. Peaks in density at 240, 292, 312, 335, and $373 \mathrm{~m}$ core depth below seafloor (CSF) or abrupt changes in density at 241.3 and $330.8 \mathrm{~m}$ CSF are considered possible indicators of fault locations.

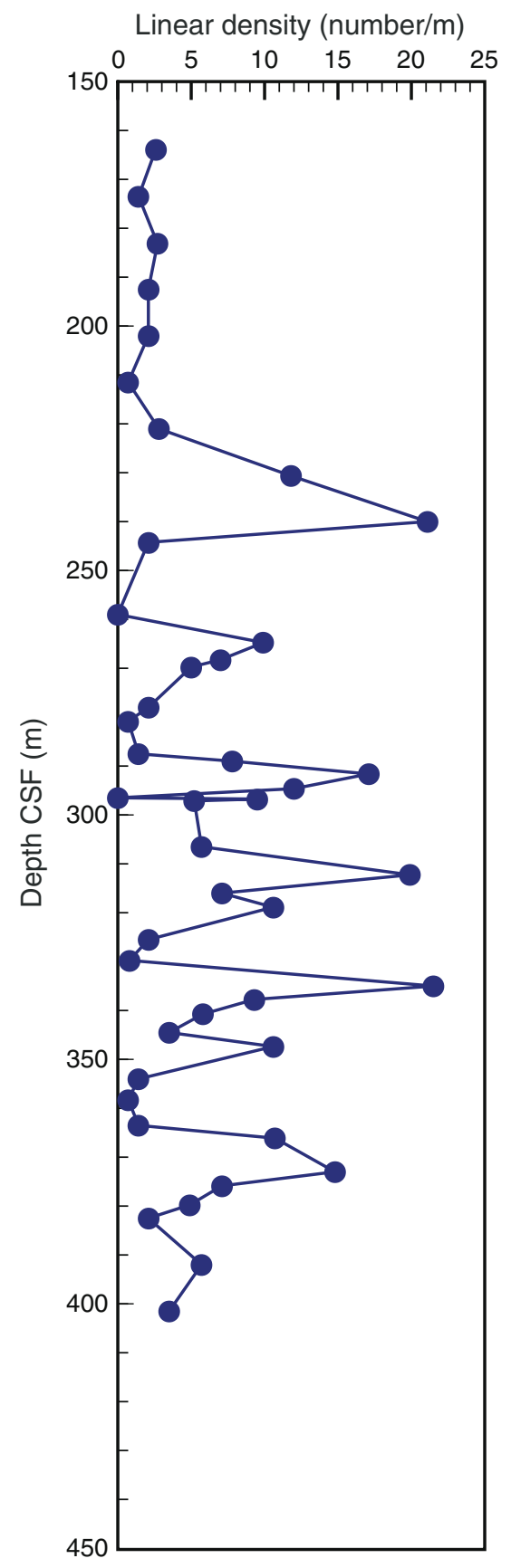


Figure F22. Photograph of vertical sand dike (interval 316-C0006E-45X-7, 11-27 cm) (370.18 m CSF). Red dashed lines = boundaries, arrows = biscuiting boundaries filled with mud. The sand dike is cut by biscuiting boundaries, suggesting sand injection is natural in origin.

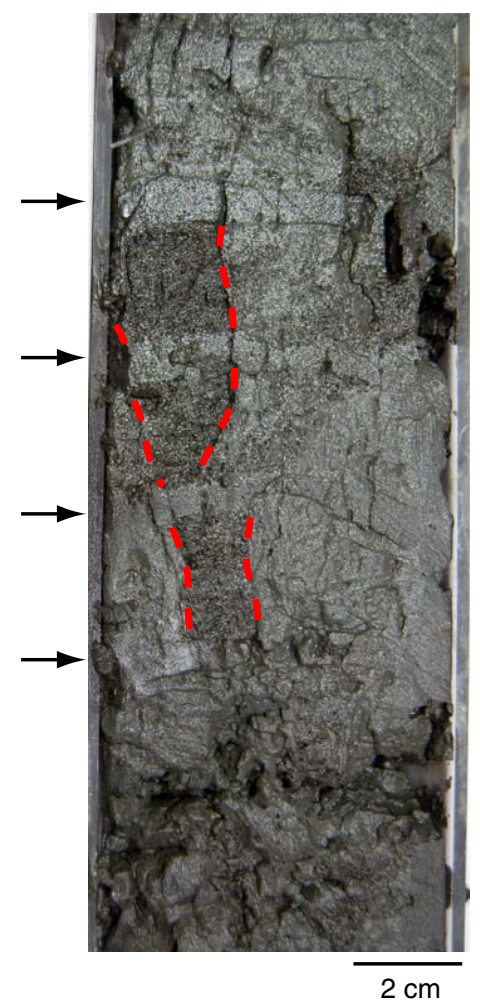


Figure F23. Distribution of deformed intervals along with nonrecovered sections across fractured/brecciated section $. \mathrm{CSF}=$ core depth below seafloor. Red arrows $=$ locations of highly deformed intervals (concentrated zones of deformation), which could correspond to faults on the basis of multiple observations of fault-related features (see text).

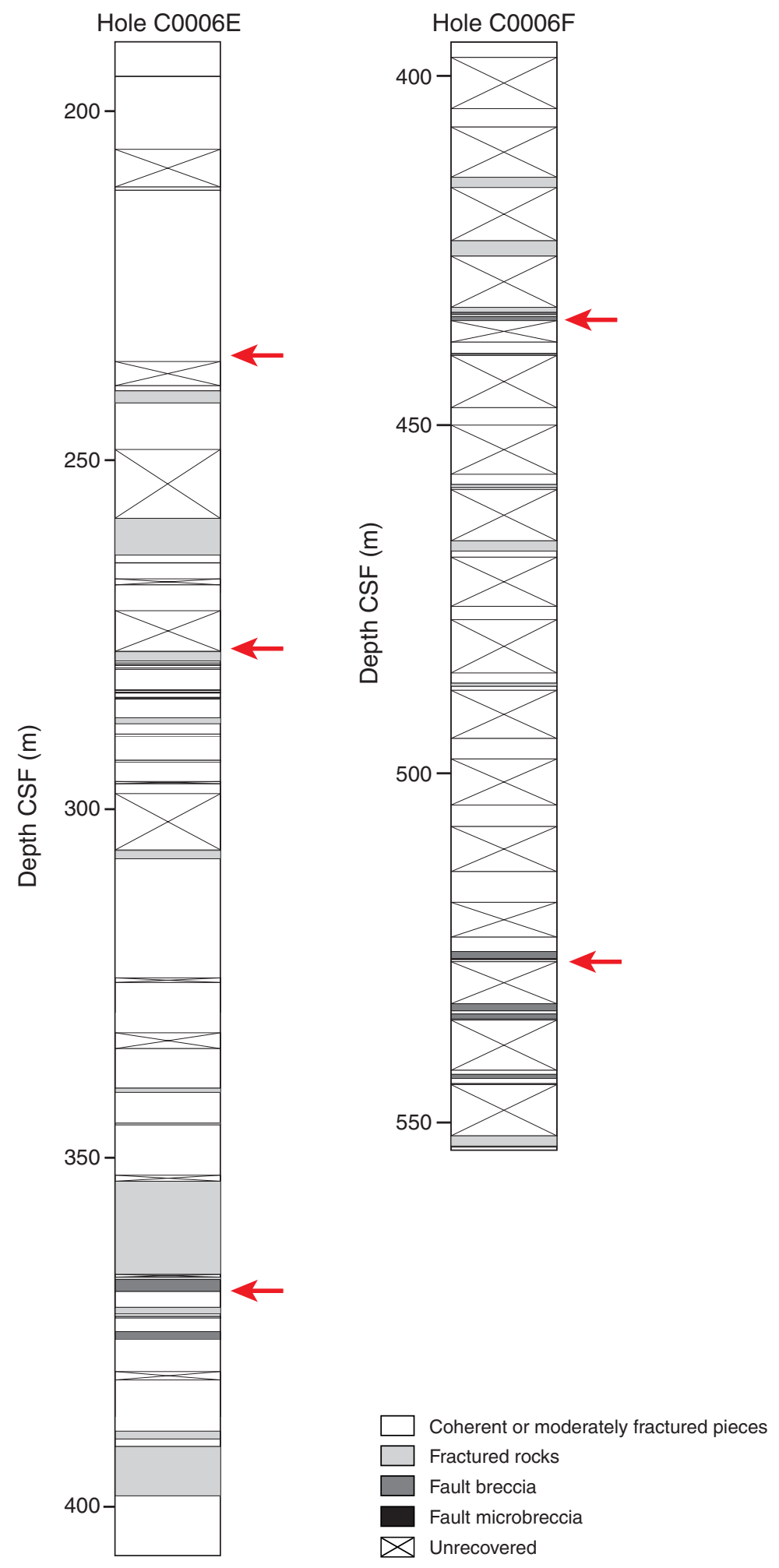


Figure F24. Images of prominent fracture surface at 235.30 m CSF (interval 316-C0006E-31X-5, 110-128 cm), as it appears in CT scan images. A. View along strike of the surface showing true dip of $29^{\circ}$ in the direction $\mathrm{N} 133^{\circ} \mathrm{E}$, approximately parallel to the plate convergence direction. Also shown are three horizontal slices from (B) above, (C) through, and (D) just below the prominent surface, showing a change in the fracture fabric across the discontinuity.
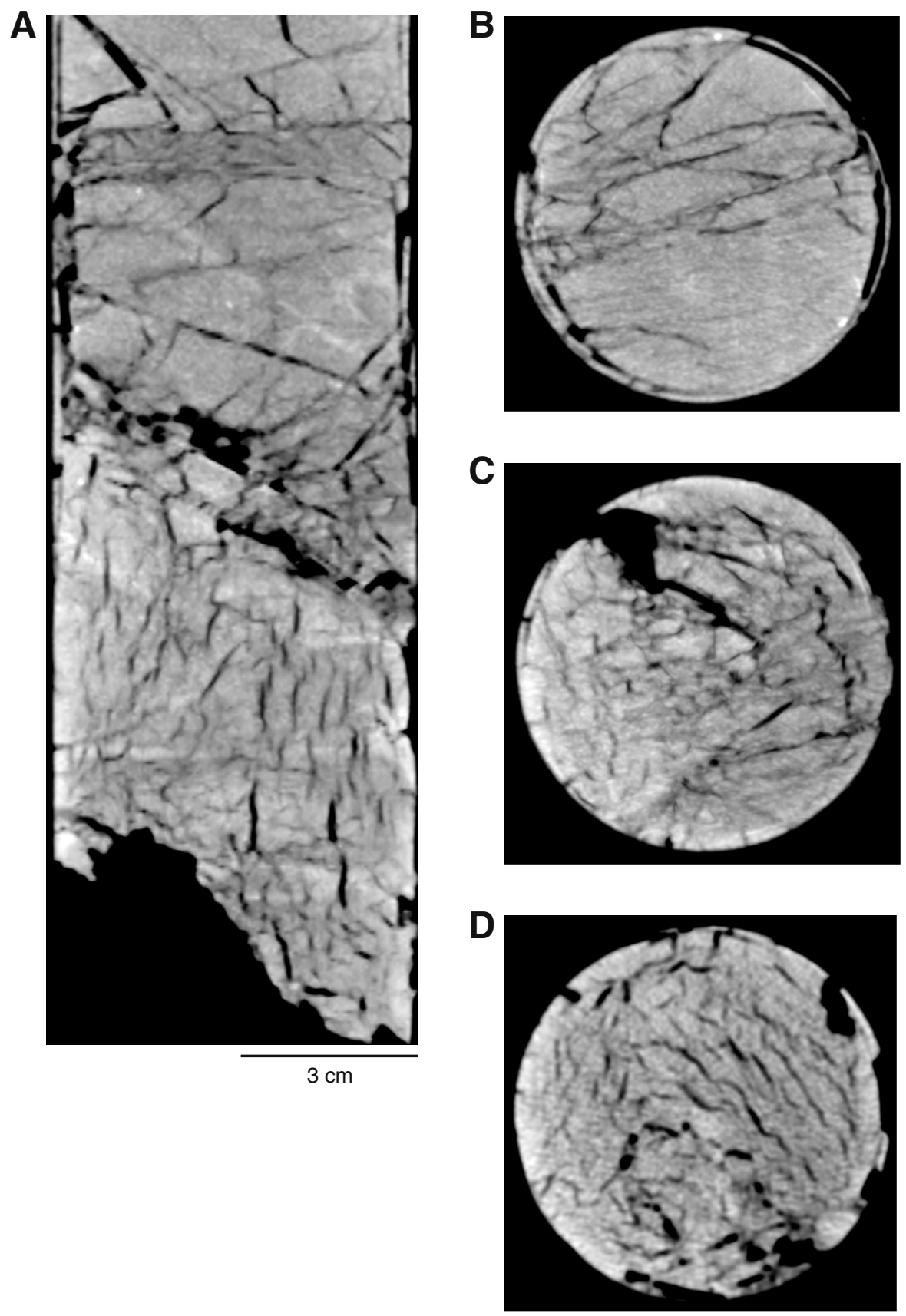
Figure F25. Photographs of strongly fractured rocks and tectonic breccias (Core 316-C0006E-39X) with corresponding CT images. A. Close-up of tectonic protobreccia (interval 316-C0006E-39X-1, 6-12 cm). B. Strongly fractured interval (Sections 316-C0006E-39X-1 and 39X-2). Note the presence of relatively intact pieces.

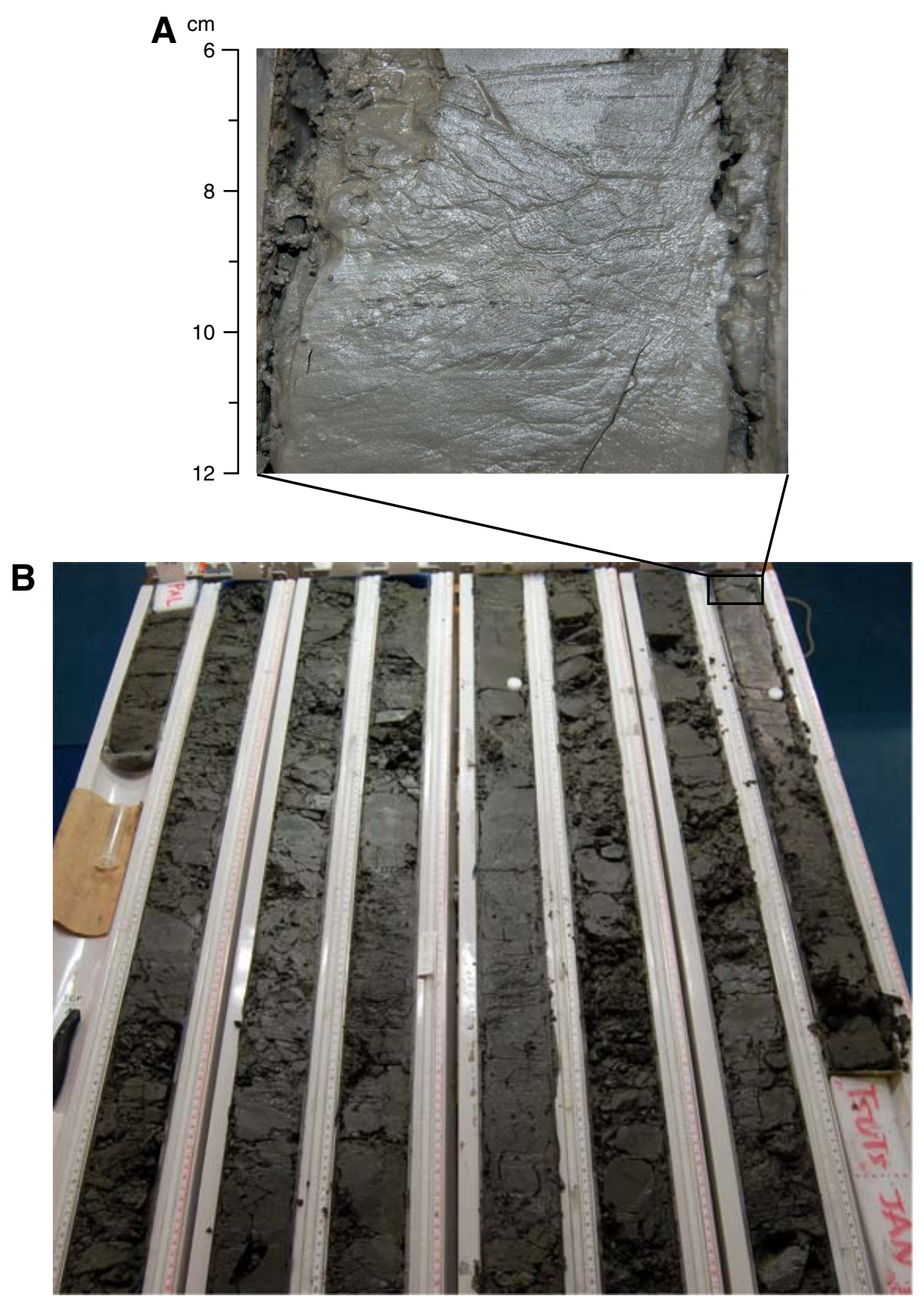


Figure F26. Tectonic breccia at $369 \mathrm{~m}$ CSF (Core 316-C0006E-45X). A. Close-up photograph and CT image of brecciated mudstone (interval 316-C0006E-45X-5, 46-61 cm). B. Boundary (red arrow) between breccia and unbroken intervals.
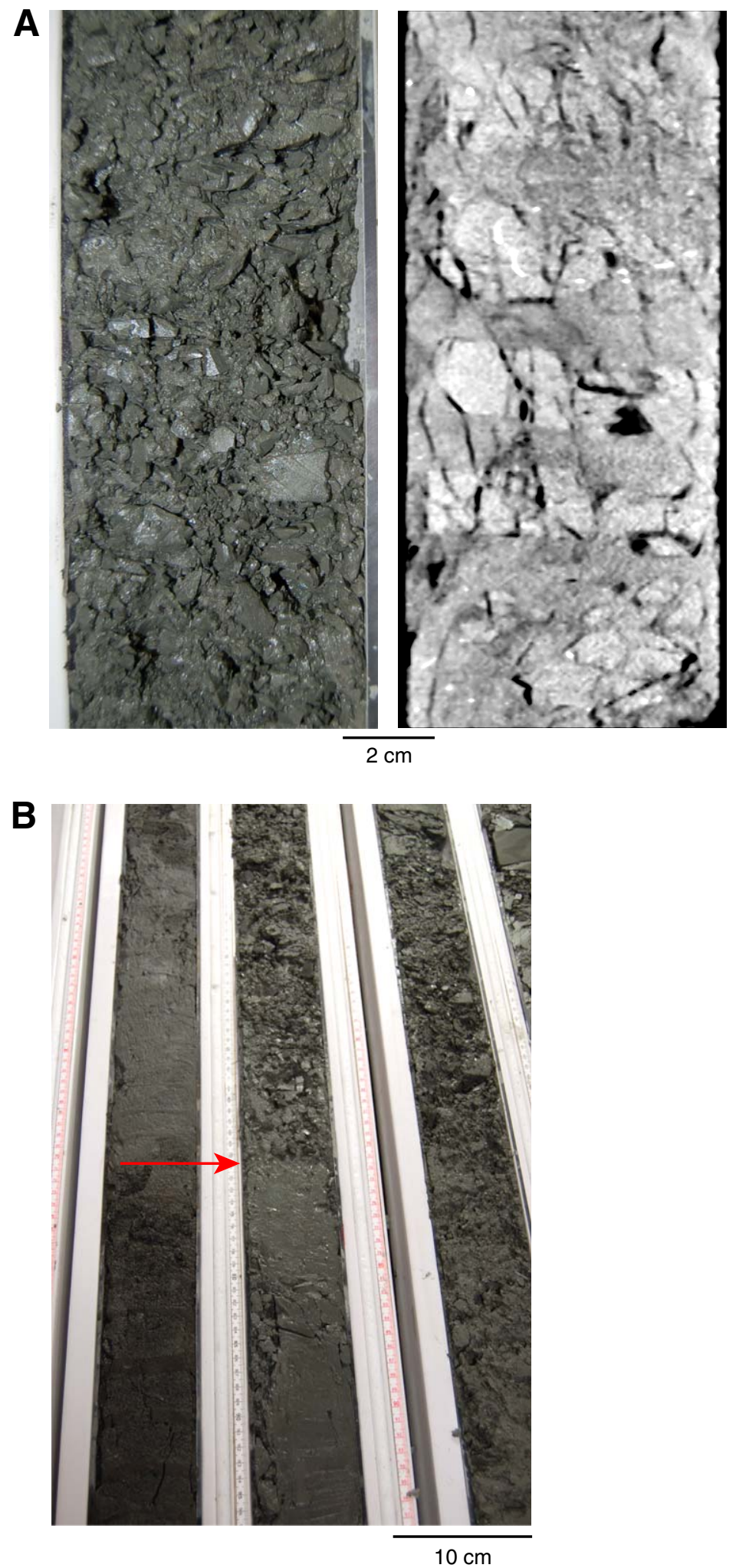
Figure F27. Photograph of tectonic breccia (interval 316-C0006F-5R-CC, 11-23 cm).

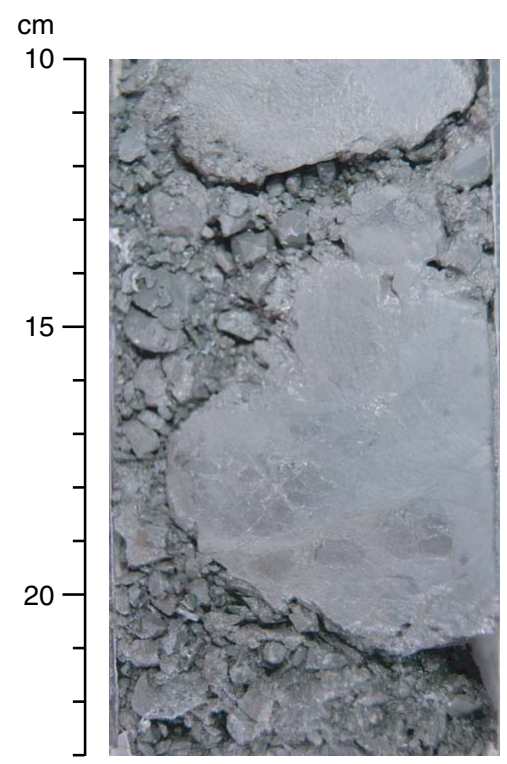


Figure F28. Fault rocks in the lower part of the fractured/brecciated zone (Cores 316-C0006E-15R and 16R). A. Microbreccia and fault gouge (double arrow) and corresponding CT image (interval 316-C0006F-15R-3, 55$69 \mathrm{~cm}$ ). B. Photomicrograph of fault gouge shown in A, showing composite planar foliation likely of tectonic origin. C. Fault breccia and corresponding CT image (interval 316-C0006F-16R-2, 42-58 cm).
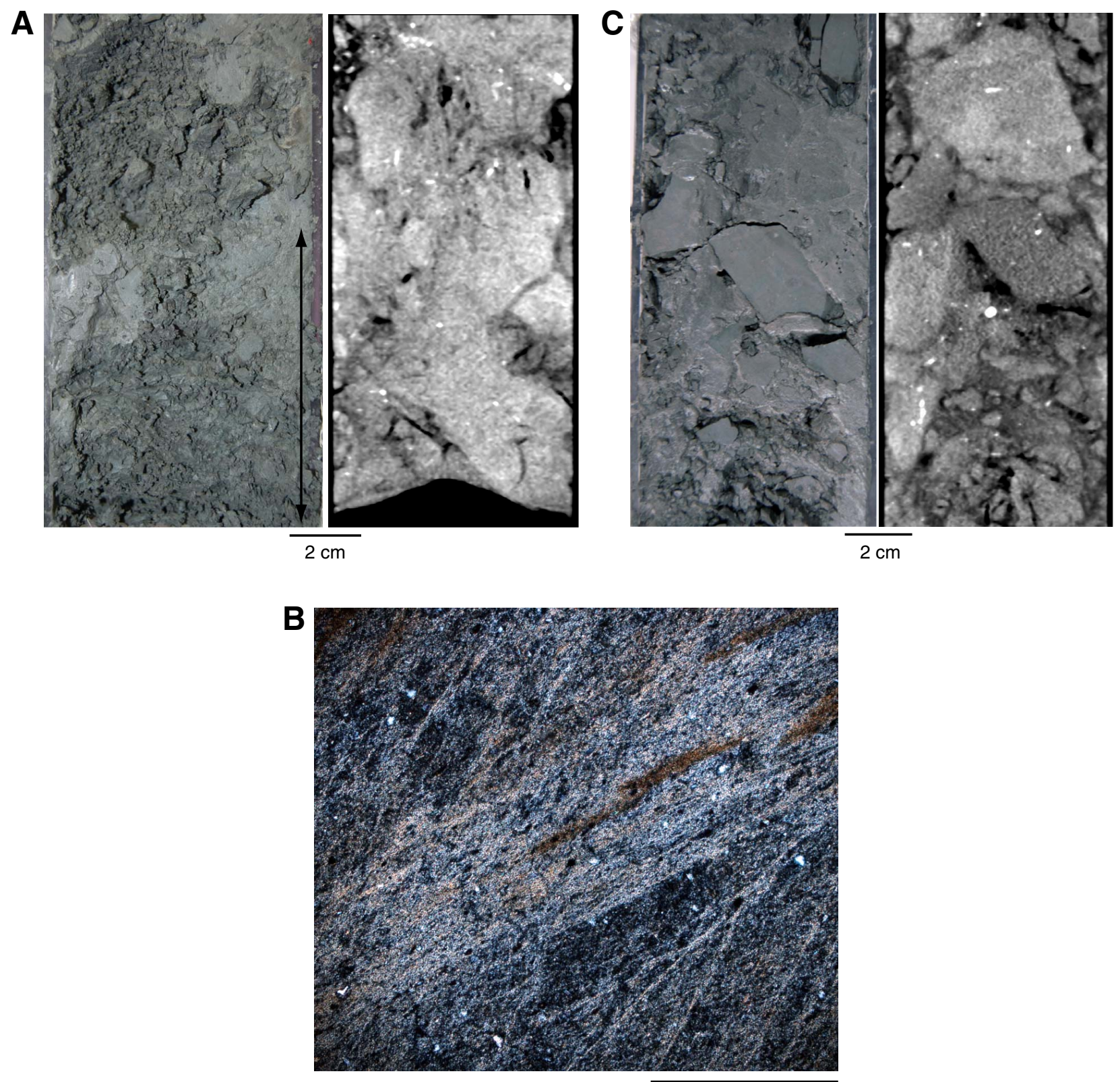

$1 \mathrm{~mm}$ 
Figure F29. Photographs of normal faults in bioturbated hemipelagic mudstone. A. Concentration of faults (interval 316-C0006F-7R-1, 54-66 cm). B. Normal fault crosscutting sediment-filled veins (interval 316-C0006F$8 \mathrm{R}-1,6-11 \mathrm{~cm})$. Half arrows $=$ sense of shear.
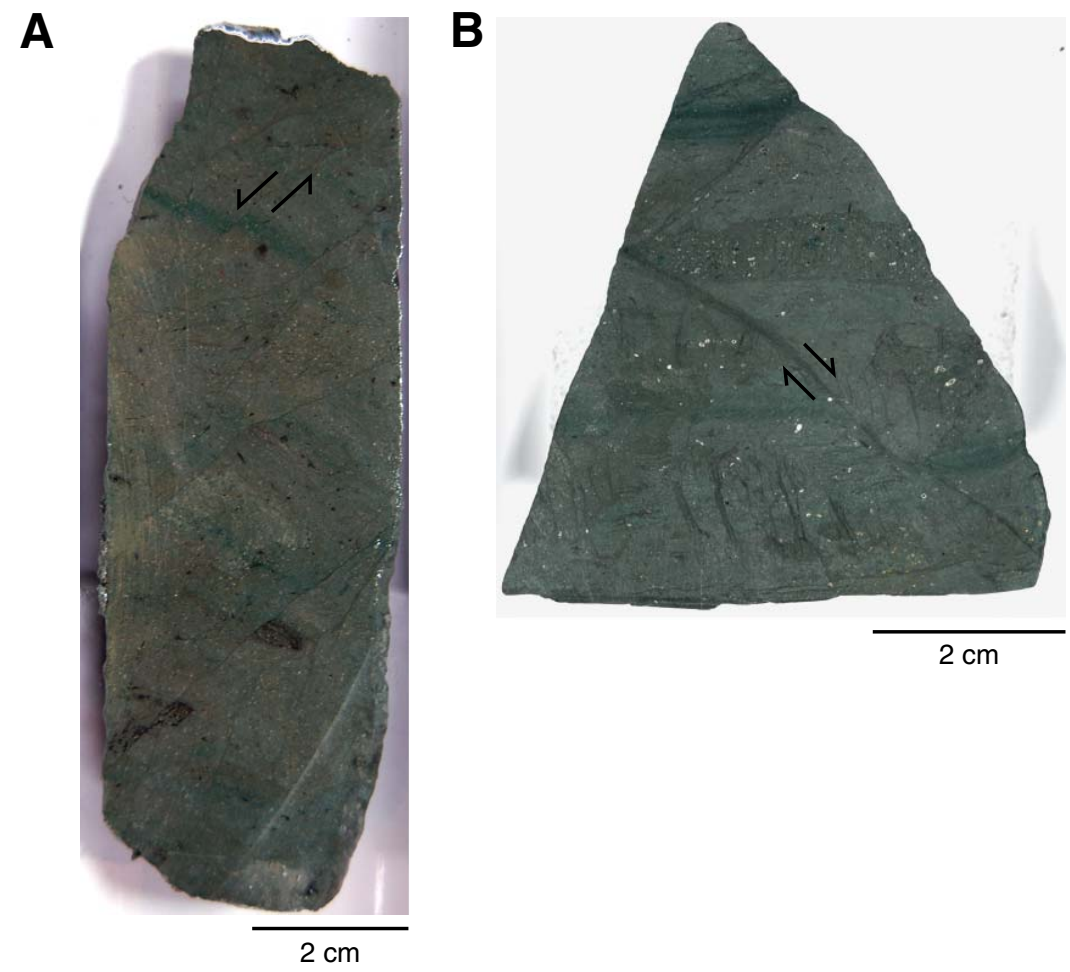
Figure F30. Location of faults identified on basis of multiple structural observations in Holes C0006E and C0006F with important lithologic and biostratigraphic boundaries indicated, projected on a nearby seismic reflection profile oriented approximately perpendicular to the plate boundary (see Moore et al.). Correlation of structurally defined faults with stratigraphic boundaries and inclined seismic reflectors is readily apparent. CSF $=$ core depth below seafloor. $\mathrm{VE}=$ vertical exaggeration .

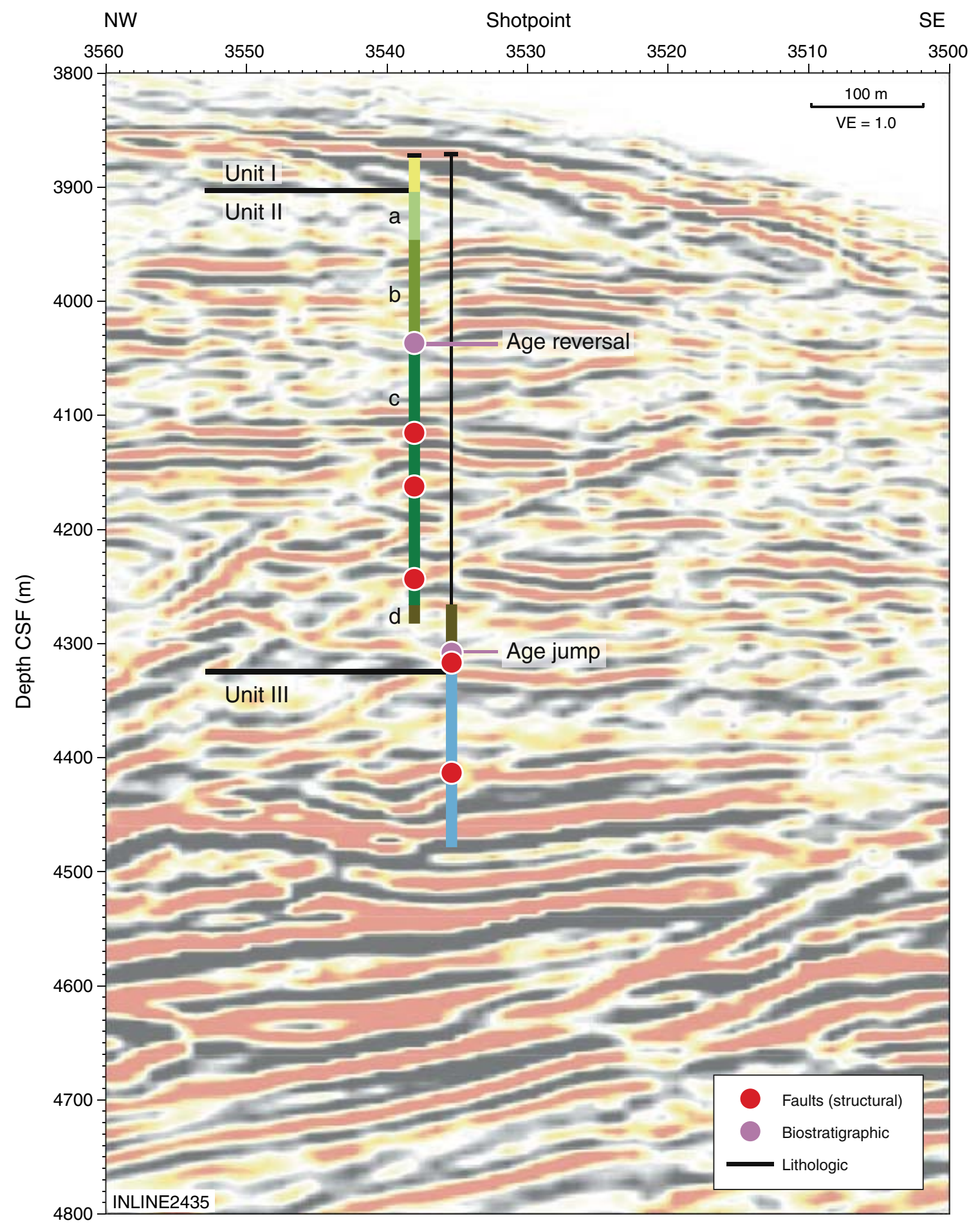


Figure F31. Age vs. depth based on nannofossil events and magnetostratigraphic data, Holes C0006E and C0007F. Gray interval = section containing reworked material, indistinct repetitions, and/or possible hiatus/ erosive events; below gray interval $=$ top of repeated section. $\mathrm{CSF}=$ core depth below seafloor.

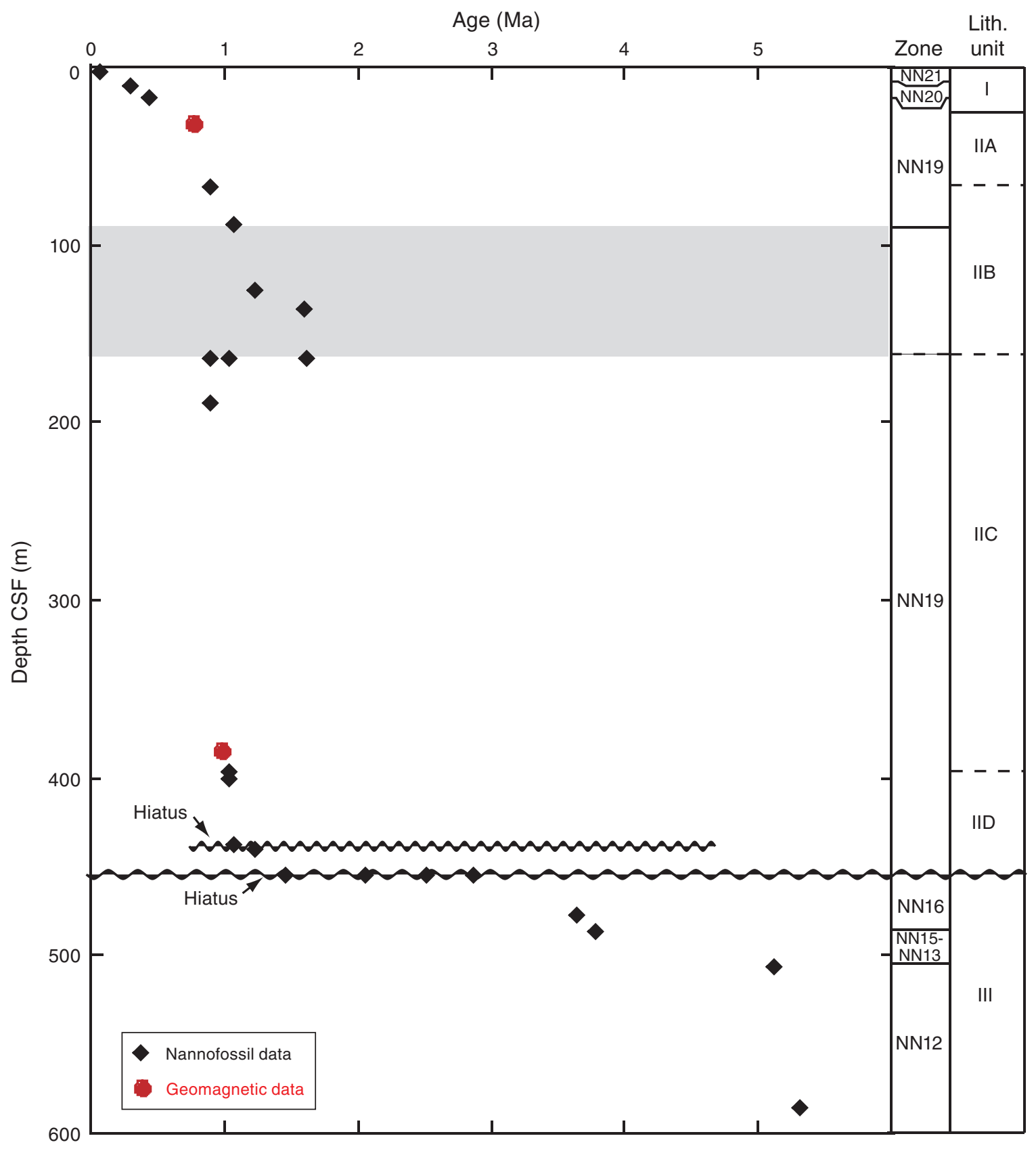


Figure F32. Magnetic susceptibility and remanent magnetization before (green) and after (purple, red, and blue) $40 \mathrm{mT}$ alternating-field (AF) demagnetization, Holes C0006E and C0007F. A. Magnetic susceptibility. B. Intensity. C. Inclination. D. Declination of archive halves. NRM inclinations are biased toward high positive inclinations, suggesting that drilling-induced magnetization is present. AF demagnetization to $40 \mathrm{mT}$ can effectively remove drilling-induced magnetization, as indicated by changes in inclination and intensity. CSF $=$ core depth below seafloor.

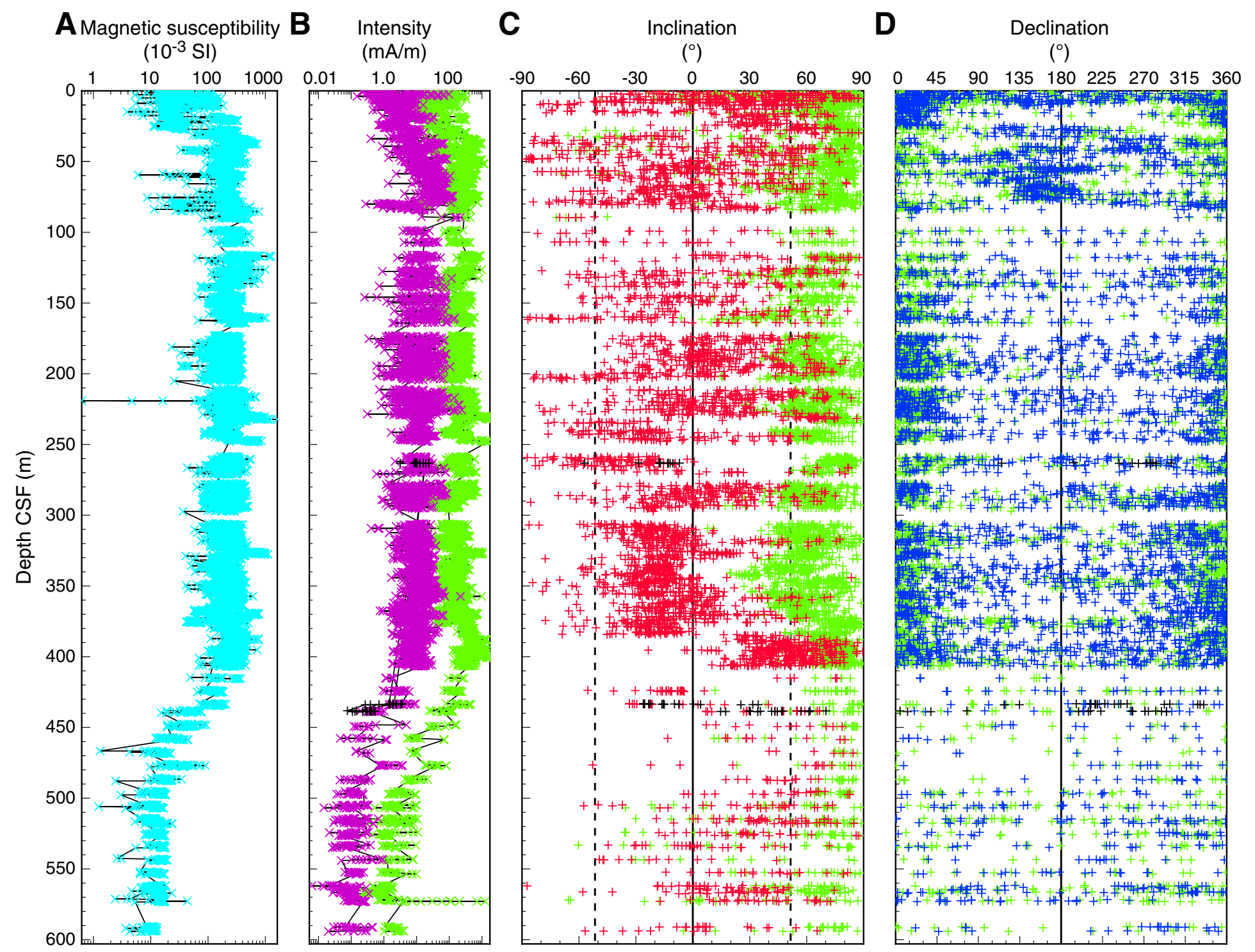


Figure F33. Vector endpoint and stereonet magnetization directions showing the results of AF demagnetization for sediments. A. Sample 316-C0006E-45X-3, 36-38 cm. B. Sample 316-C0006F-8R-1, 6-8 cm. C. Sample 316C0006E-46X-2, 67-69 cm. Black and white squares = projection of magnetization vector endpoint on the horizontal and vertical planes, respectively. NRM = natural remanent magnetization.

A

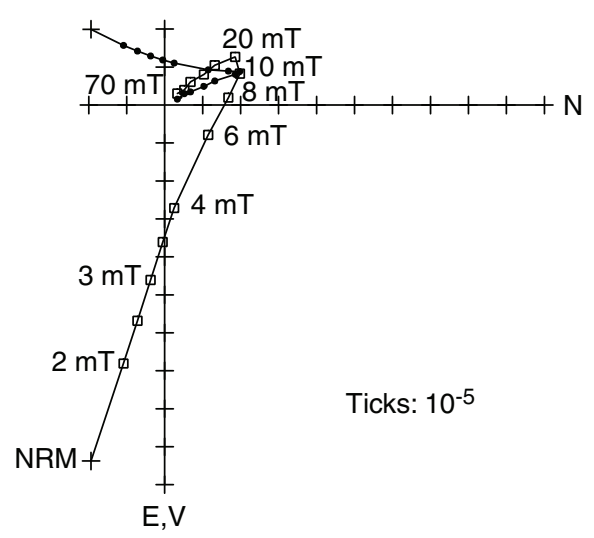

B

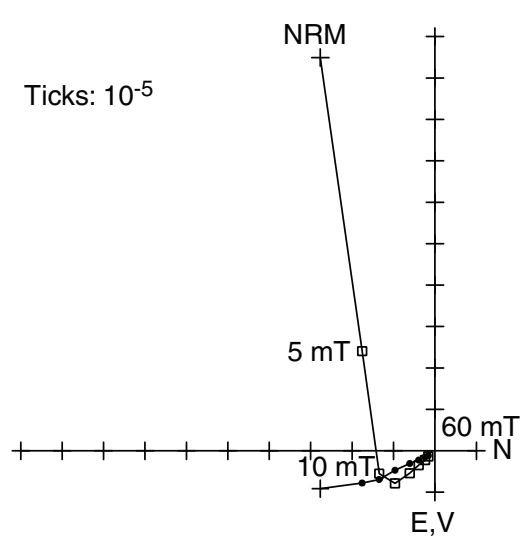

C

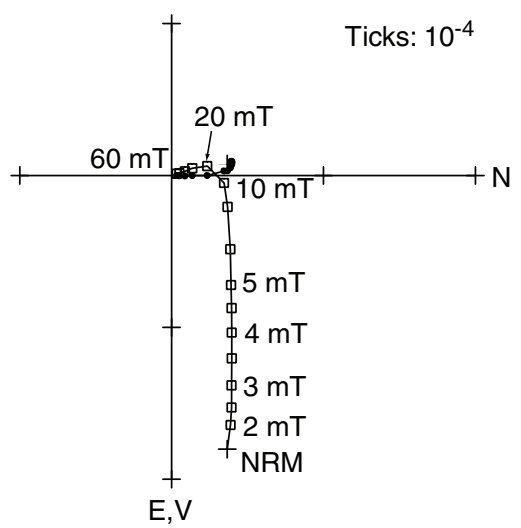

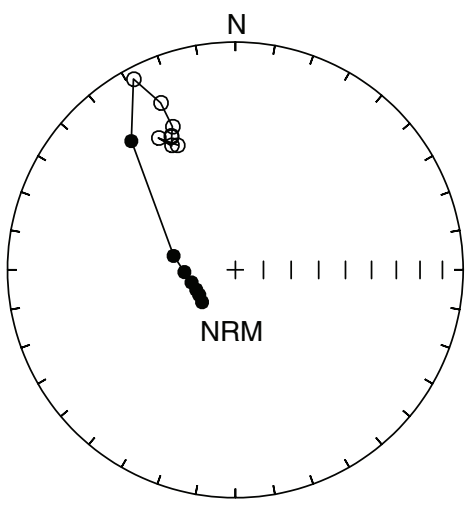
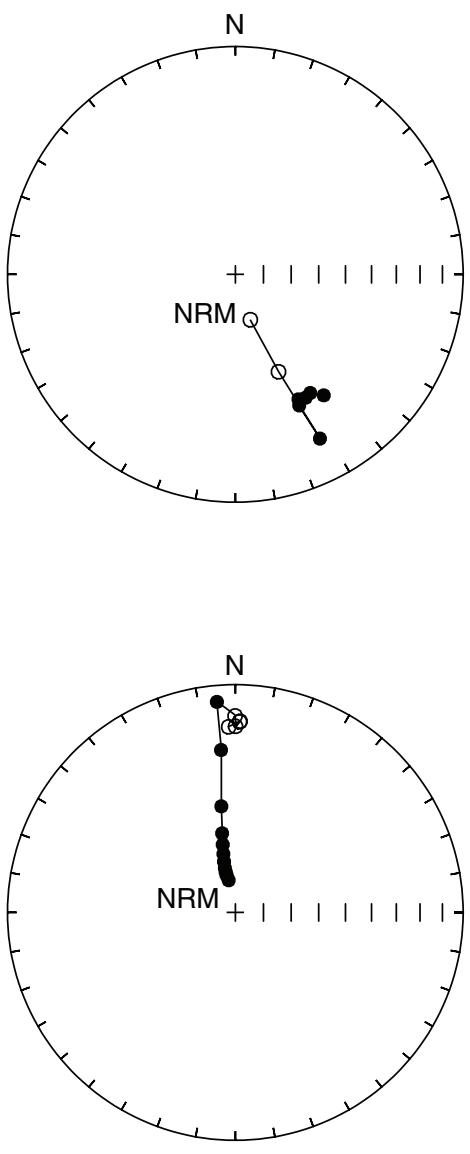
Figure F34. Vector endpoint and stereonet magnetization directions showing the results of thermal demagnetization for sediments. A. Sample 316-C0006E-39X-2, 38-40 cm. B. Sample 316-C0006E-46X-4, 9-11 cm. C. Sample 316-C0006F-12R-1, 15-17 cm. Black and white squares = projection of magnetization vector endpoint on the horizontal and vertical planes, respectively. $\mathrm{NRM}=$ natural remanent magnetization.

A

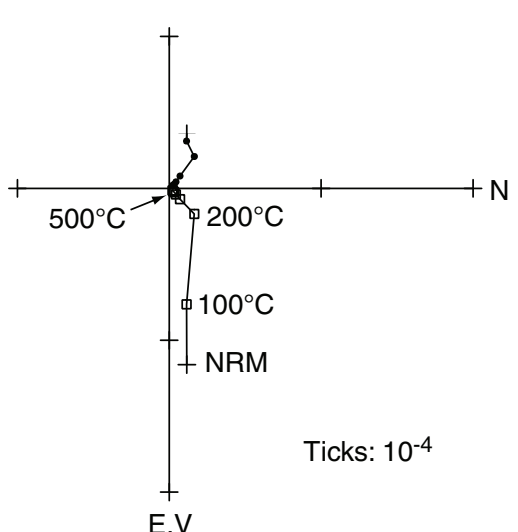

B

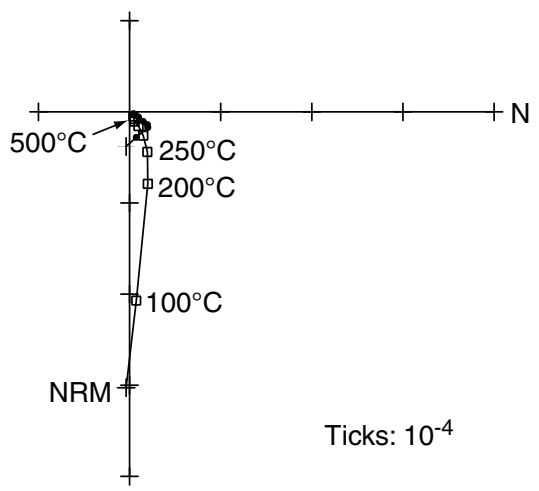

$\mathrm{E}, \mathrm{V}$

C

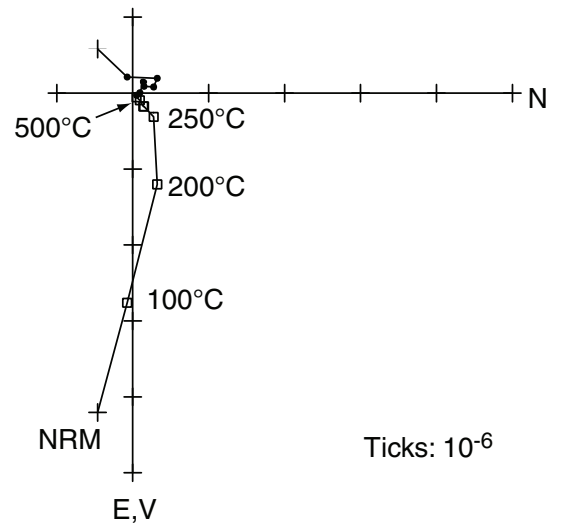

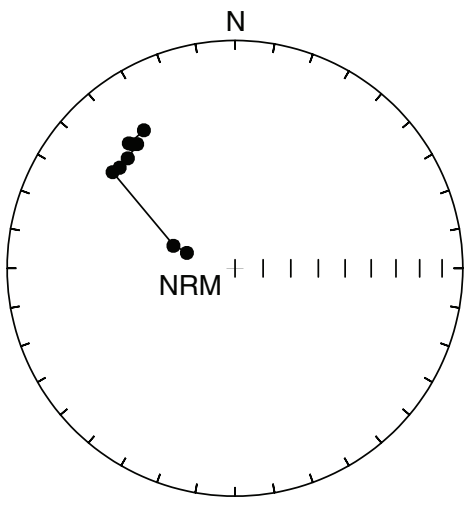
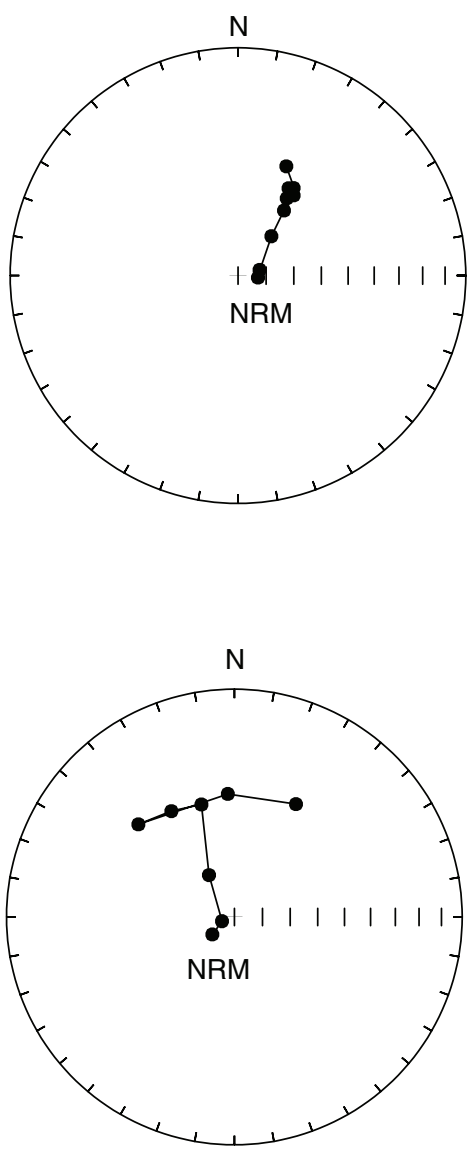
Figure F35. Histogram of inclinations isolated from discrete samples, Holes C0006E and C0006F.

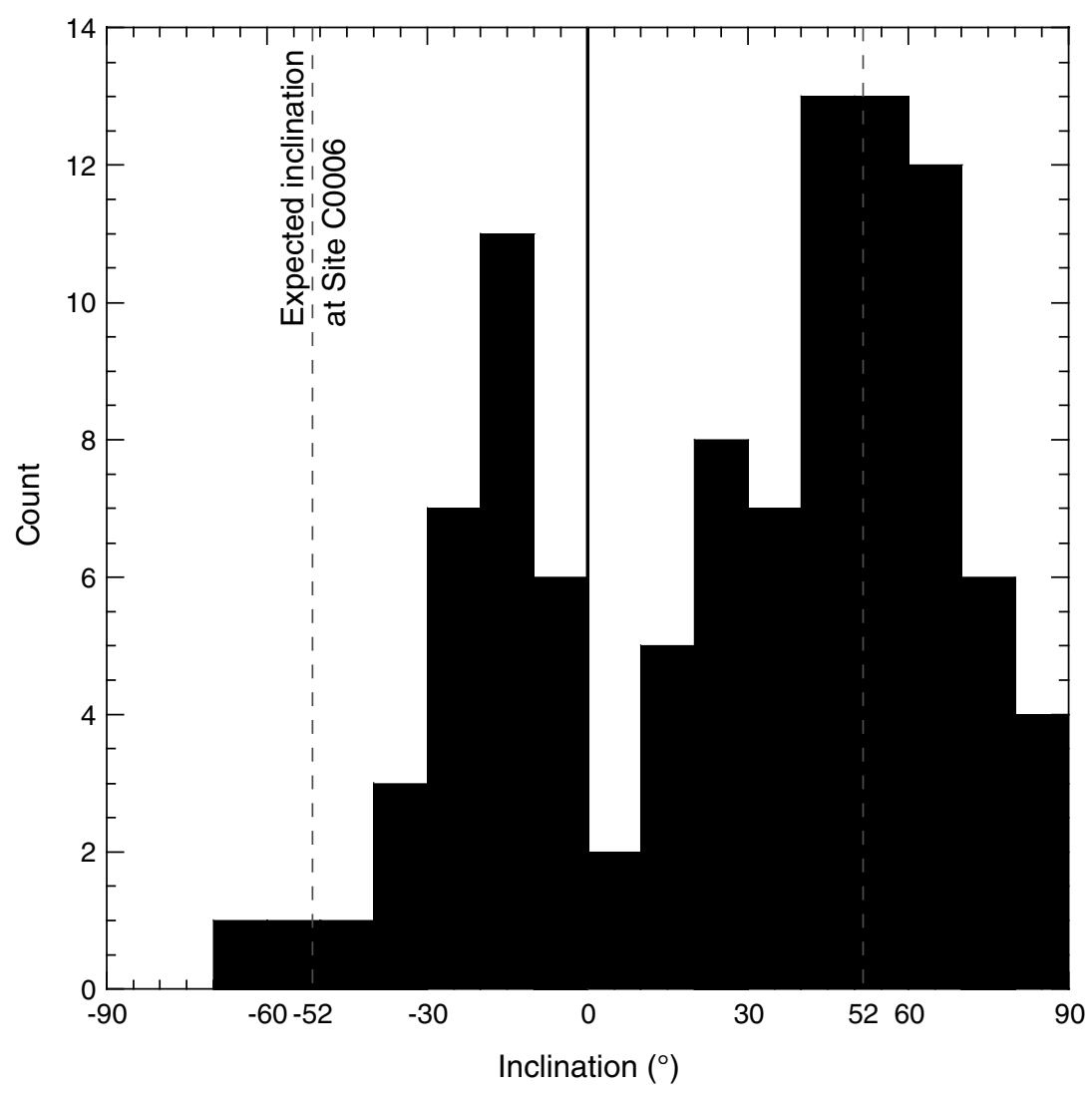


Figure F36. Downhole variation in stable magnetic inclination, inferred polarity, and biostratigraphic zones for sediments, Site C0006. CSF $=$ core depth below seafloor. Black areas = normal polarity, white areas $=$ reversed polarity, hatched area $=$ mixed polarity. $\mathrm{AF}=$ alternating field .

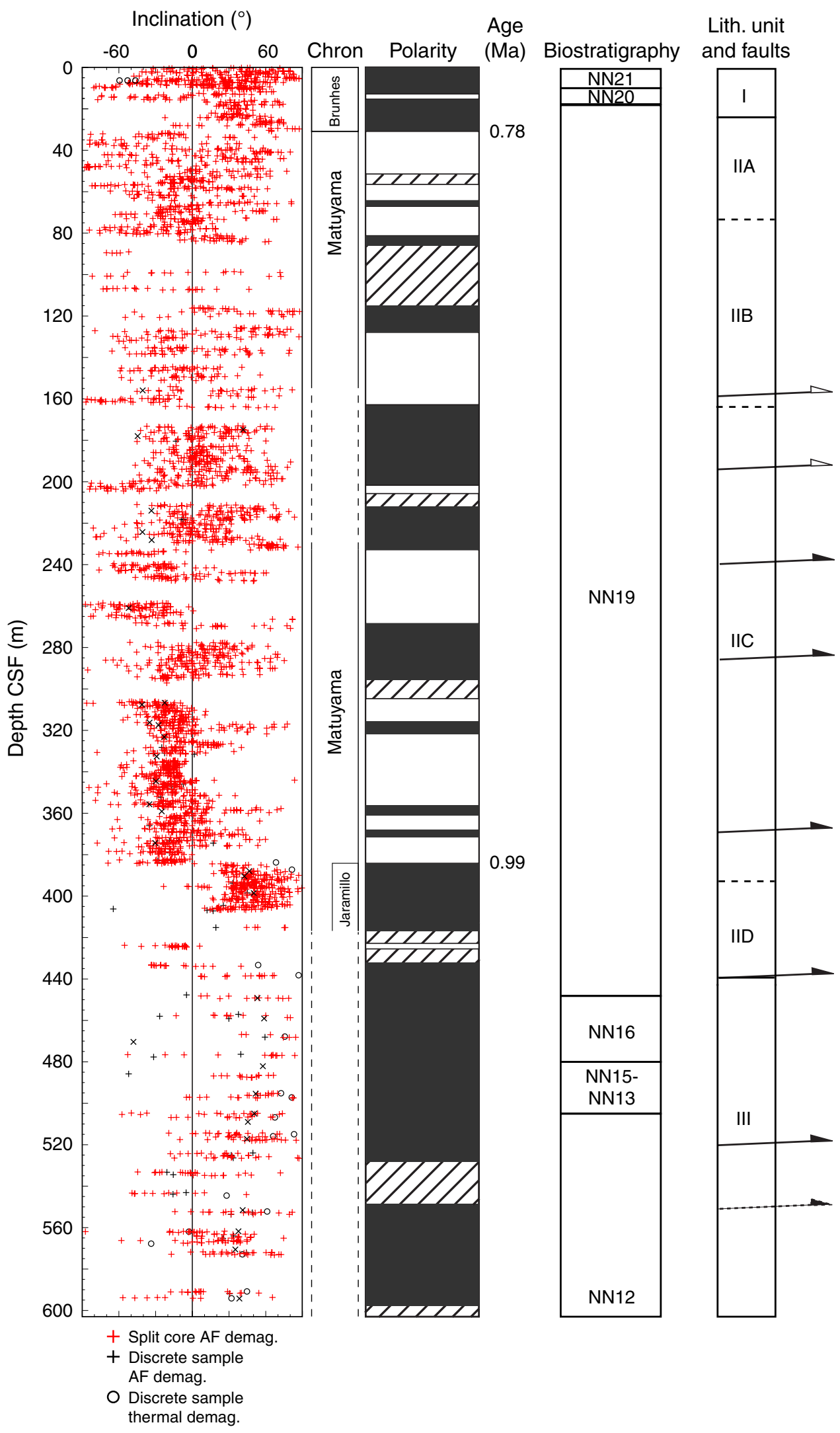


Figure F37. Concentrations of (A) salinity, (B) chloride, (C) sodium, and (D) Na/Cl from interstitial waters, Site C0006. Salinity is calculated from refractive index. $\mathrm{CSF}=$ core depth below seafloor. $\mathrm{SW}=$ seawater values.

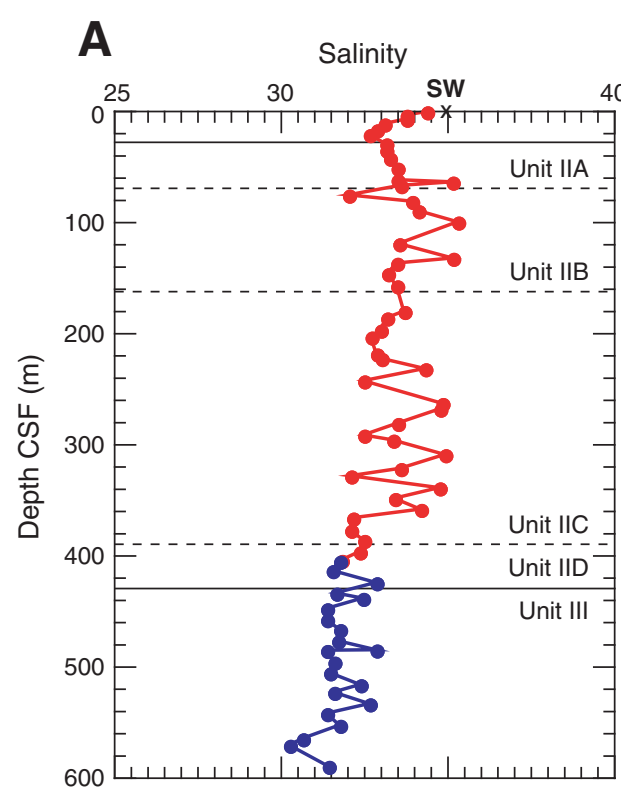

B

C

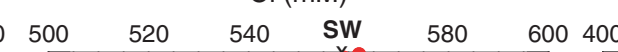

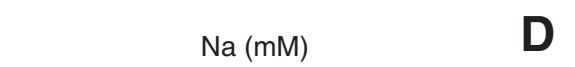

D
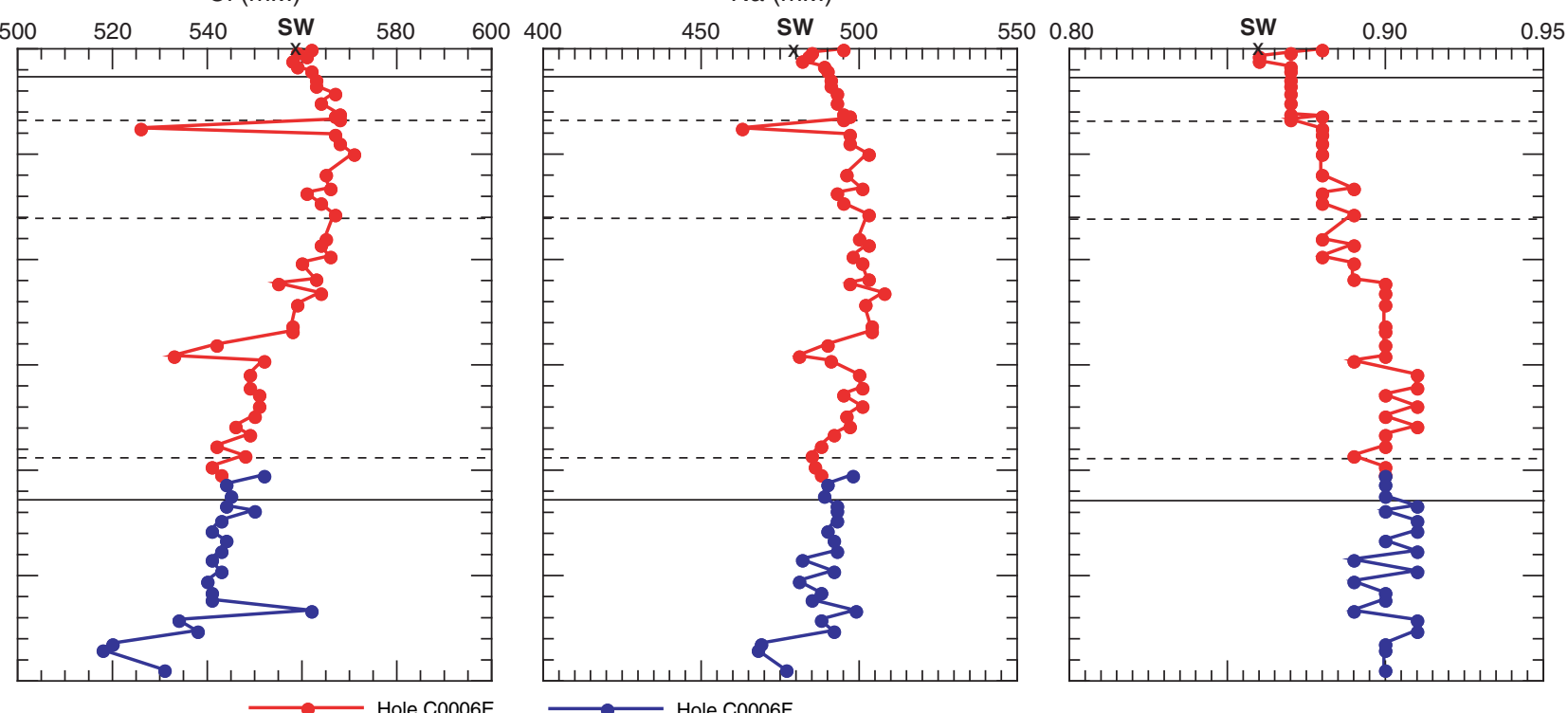
Figure F38. Concentrations of (A) sulfate, (B) alkalinity, (C) calcium, (D) magnesium, (E) pH, and (F) barium from interstitial waters, Site C0006. $\mathrm{CSF}=$ core depth below seafloor. $\mathrm{SW}=$ seawater values.

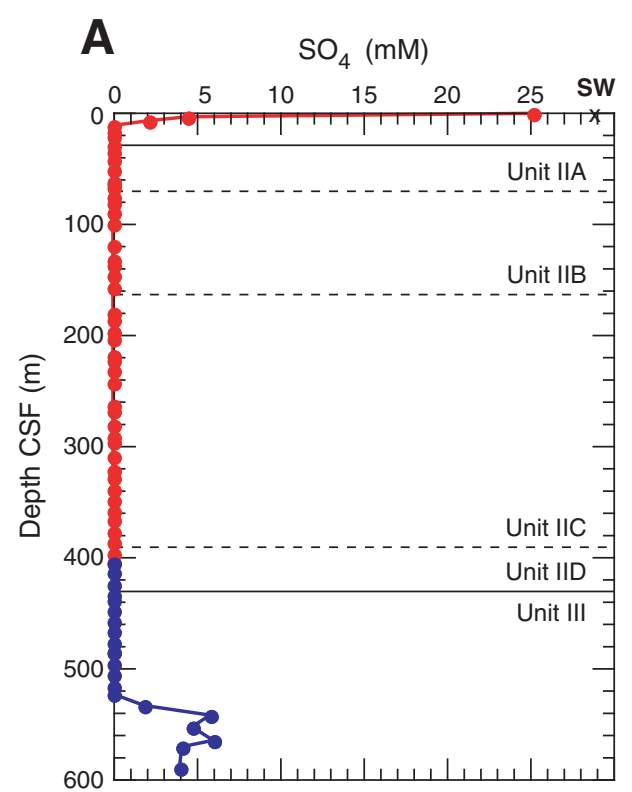

B Alkalinity $(\mathrm{mM}) \quad$ C

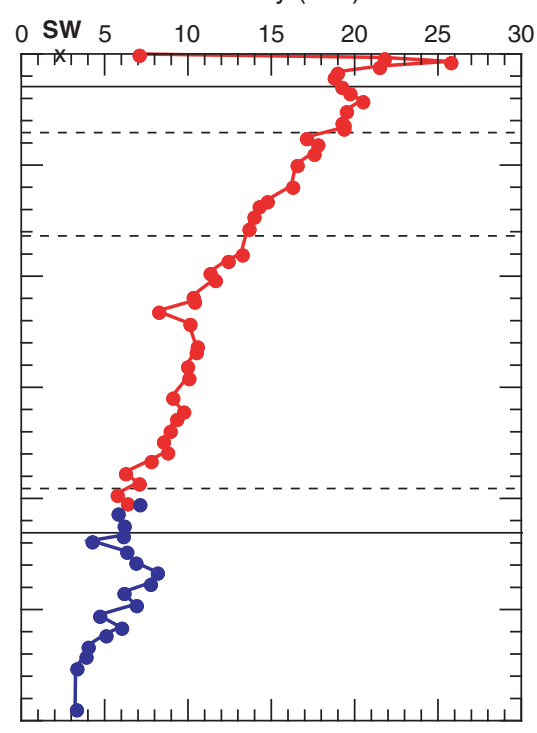

C

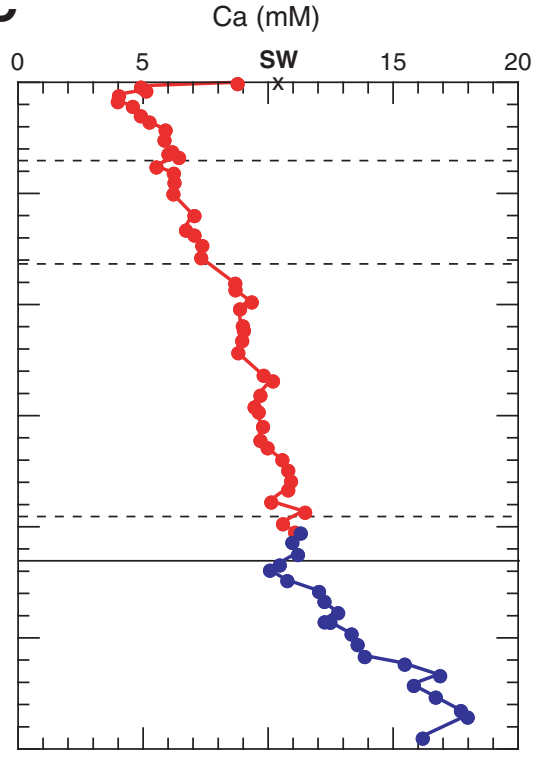

D

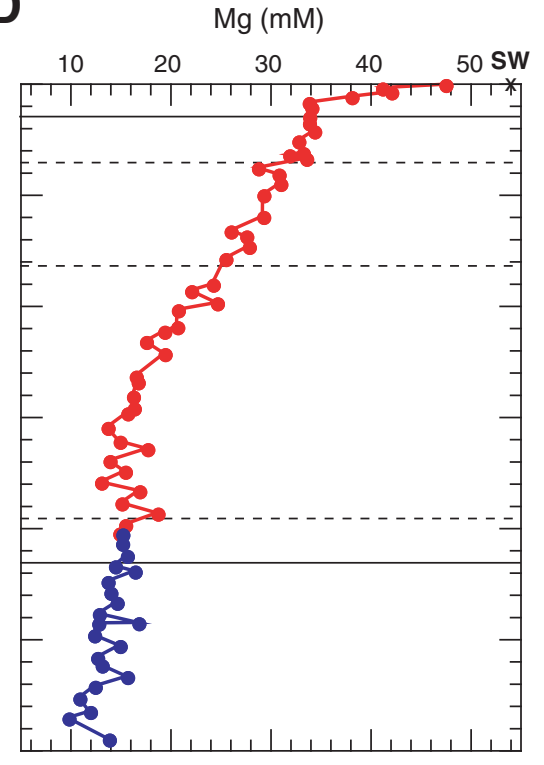

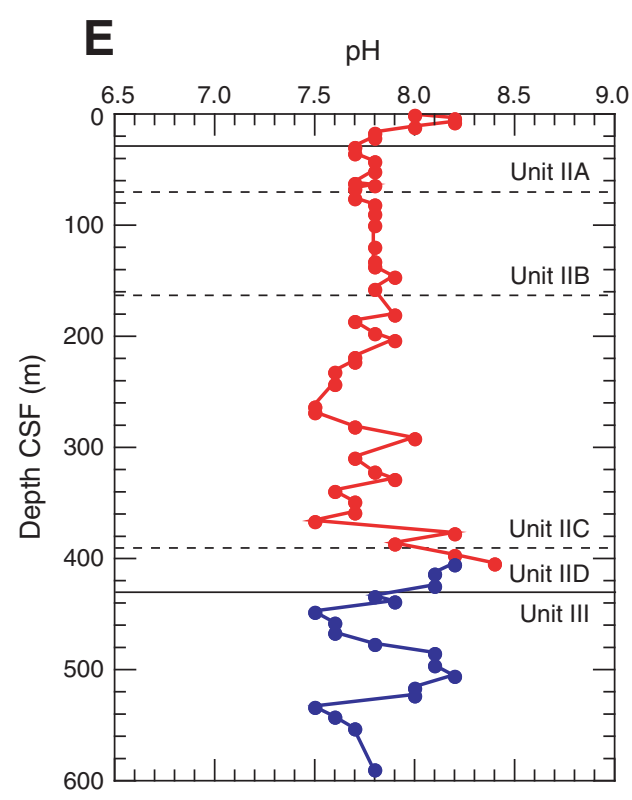

$\mathbf{F}$

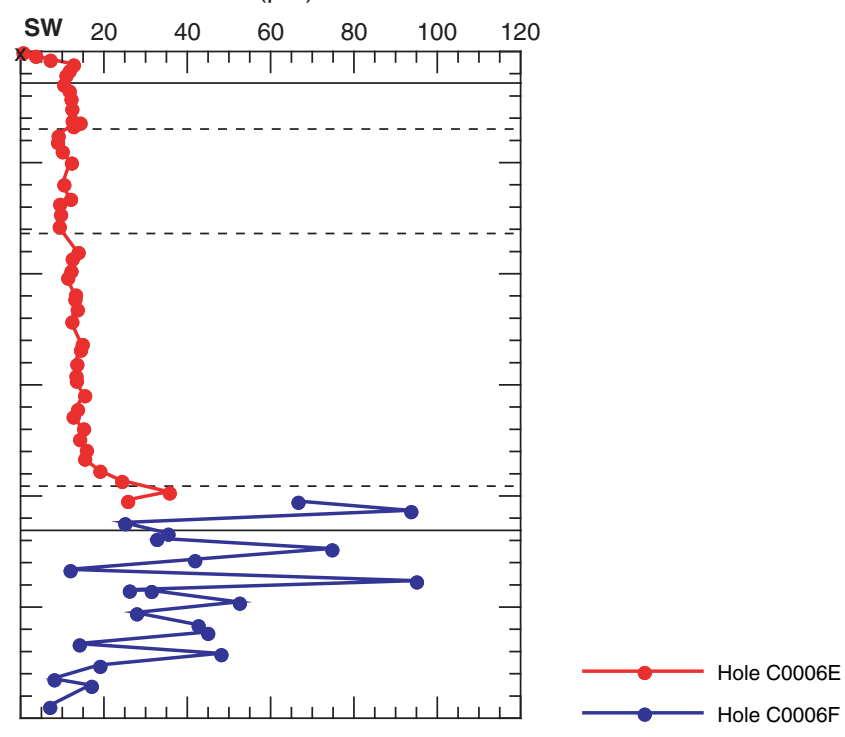


Figure F39. Concentrations of (A) ammonium, $(\mathbf{B})$ phosphate, $(\mathbf{C})$ bromide, and (D) manganese from interstitial waters, Site C0006. CSF $=$ core depth below seafloor. SW = seawater values.
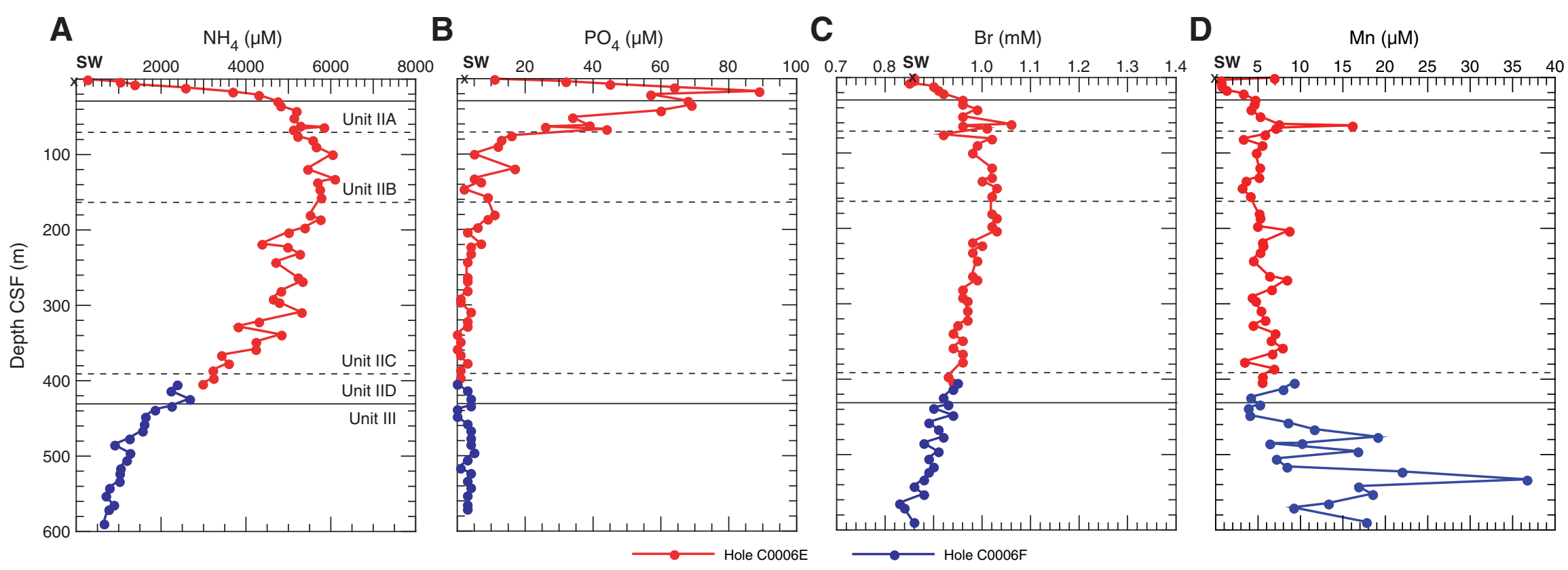
Figure F40. Concentrations of (A) lithium, (B) silica, (C) boron, (D) strontium, (E) potassium, (F) rubidium, and (G) cesium from interstitial waters, Site C0006. $\mathrm{CSF}=$ core depth below seafloor. $\mathrm{SW}=$ seawater values.

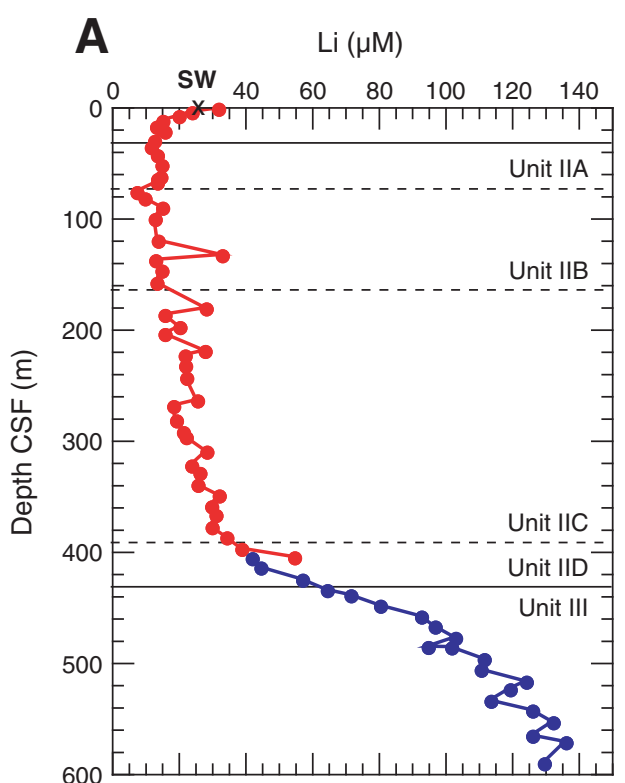

B

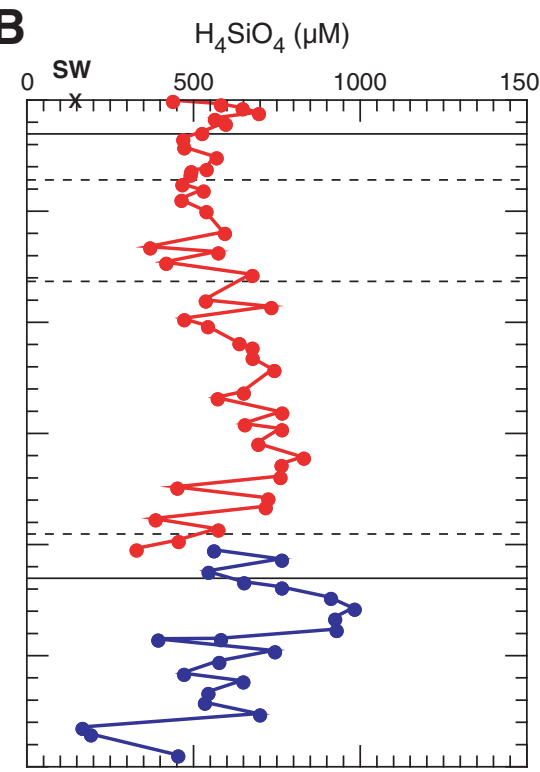

C

$\mathrm{B}(\mu \mathrm{M})$

D

F
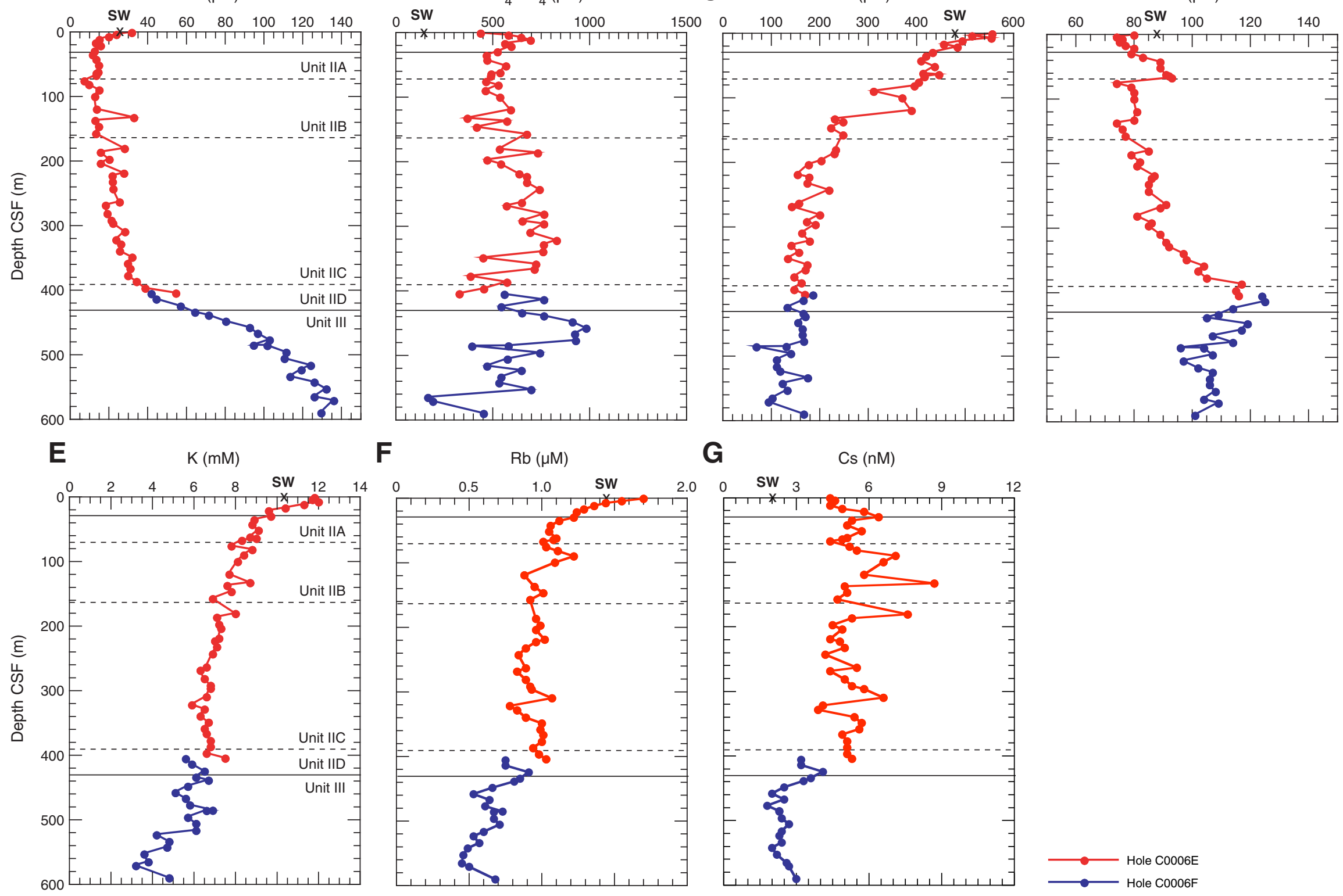

G
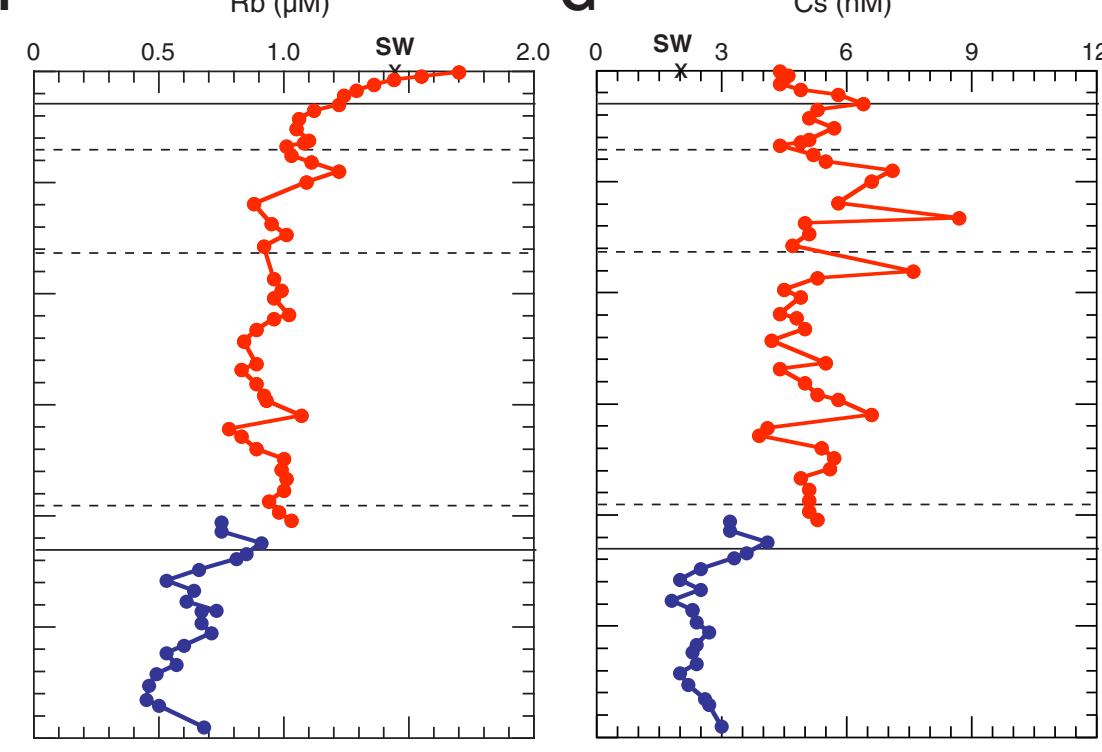

$\longrightarrow$ Hole COOO6E 
Figure F41. Concentrations of (A) iron, $(\mathbf{B})$ copper, $(\mathbf{C})$ zinc, and (D) vanadium from interstitial waters, Site C0006. CSF $=$ core depth below seafloor. SW = seawater values.
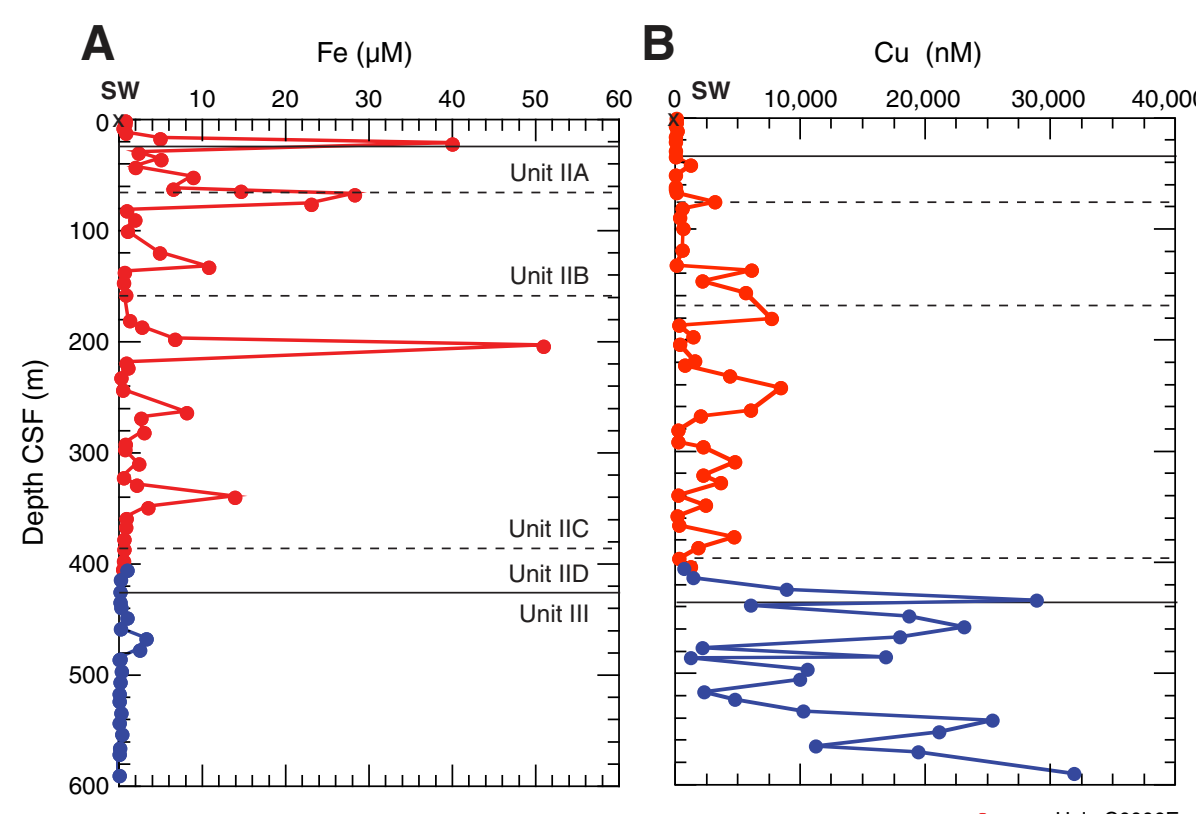

C

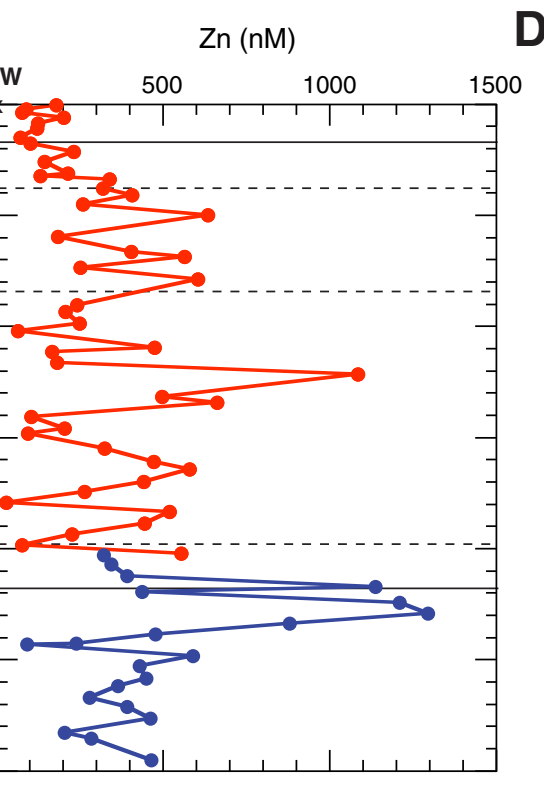

D

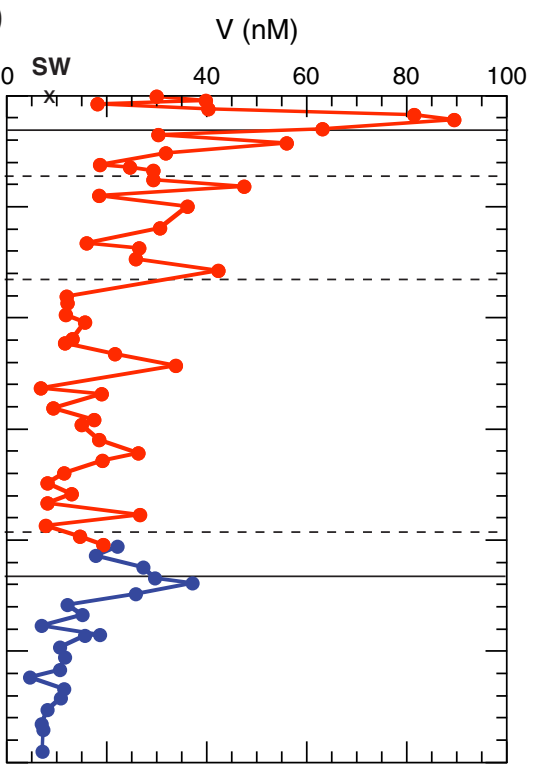

$\longrightarrow$ Hole COOO6E

$\longrightarrow$ Hole C0006F

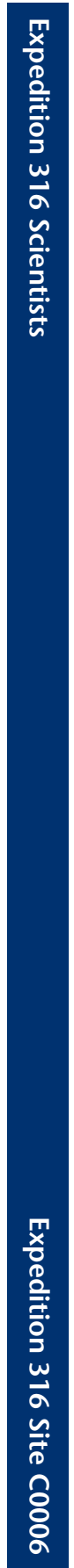


Figure F42. Concentrations of (A) molybdenum, $(\mathbf{B})$ lead, $(\mathbf{C})$ uranium, and (D) yttrium from interstitial waters, Site C0006. CSF $=$ core depth below seafloor. SW = seawater values.
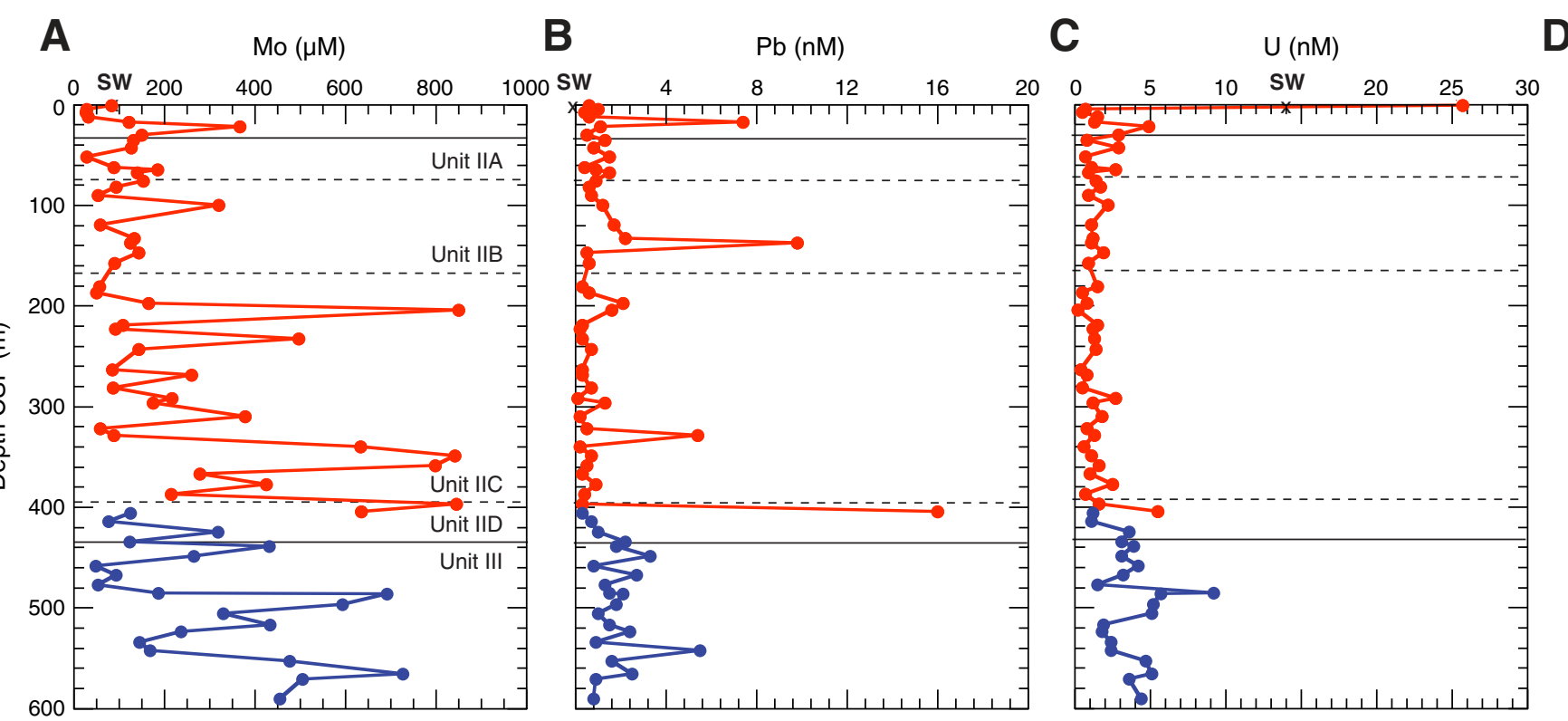

D
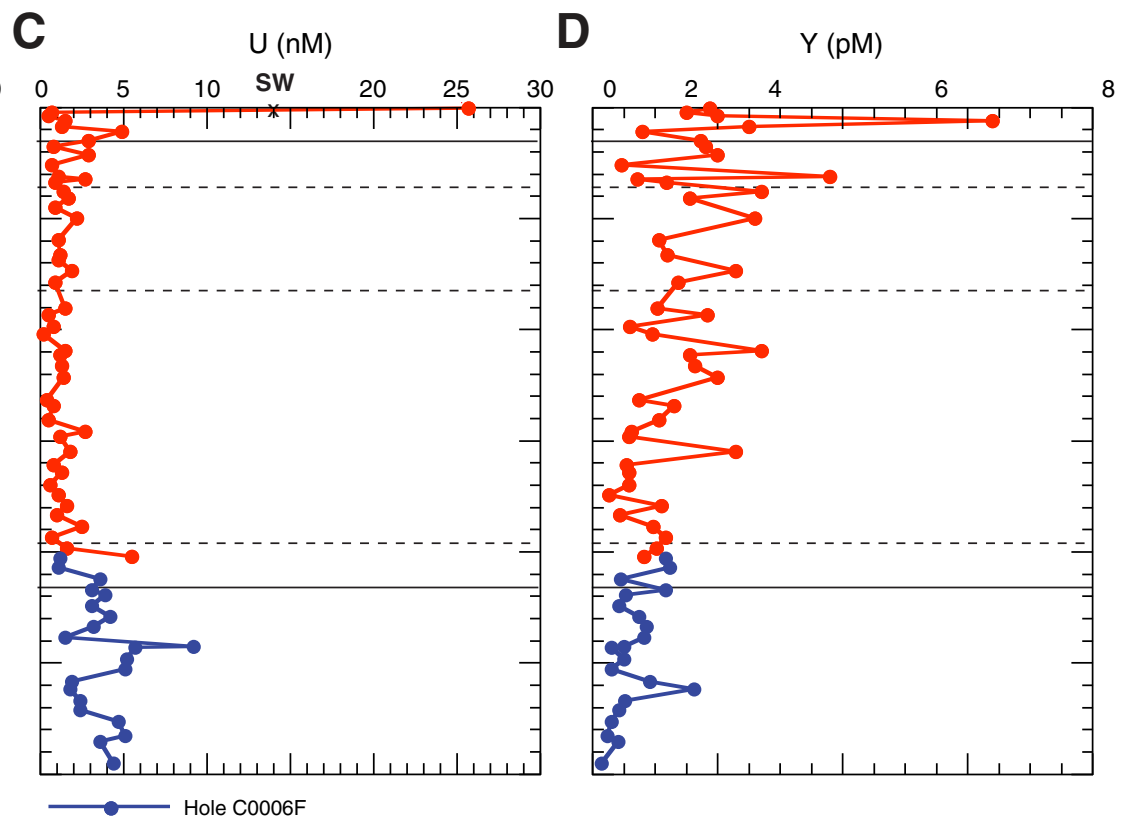

$\longrightarrow$ Hole CO006E

$\longrightarrow$ Hole CO006F 
Figure F43. $\delta^{18} \mathrm{O}$ isotopic depth profile, Site C0006. CSF = core depth below seafloor. SW = seawater value.

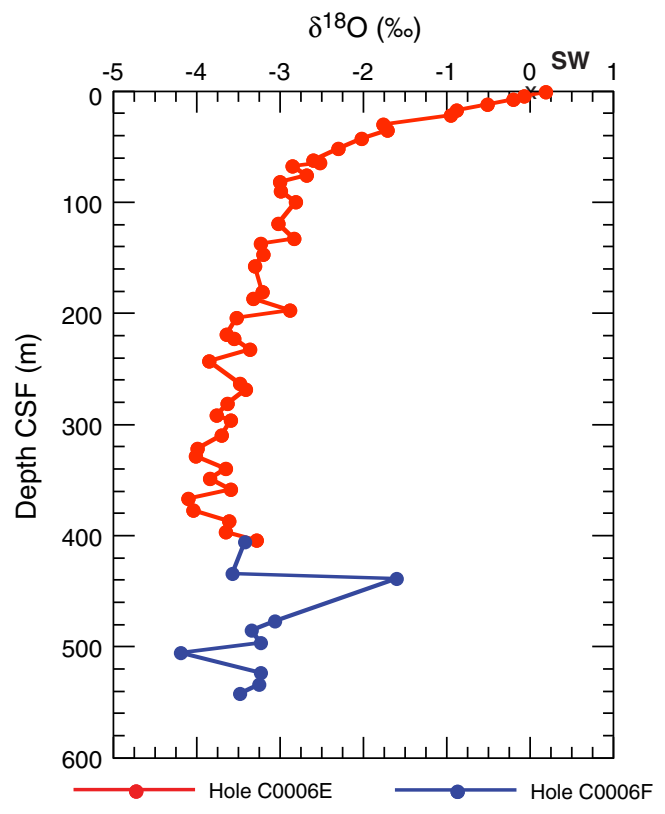


Figure F44. Dissolved methane and ethane concentrations calculated from headspace samples (see Table T16), as well as values of $C_{1} / C_{2}$ in sediments, Site C0006. $C S F=$ core depth below seafloor.

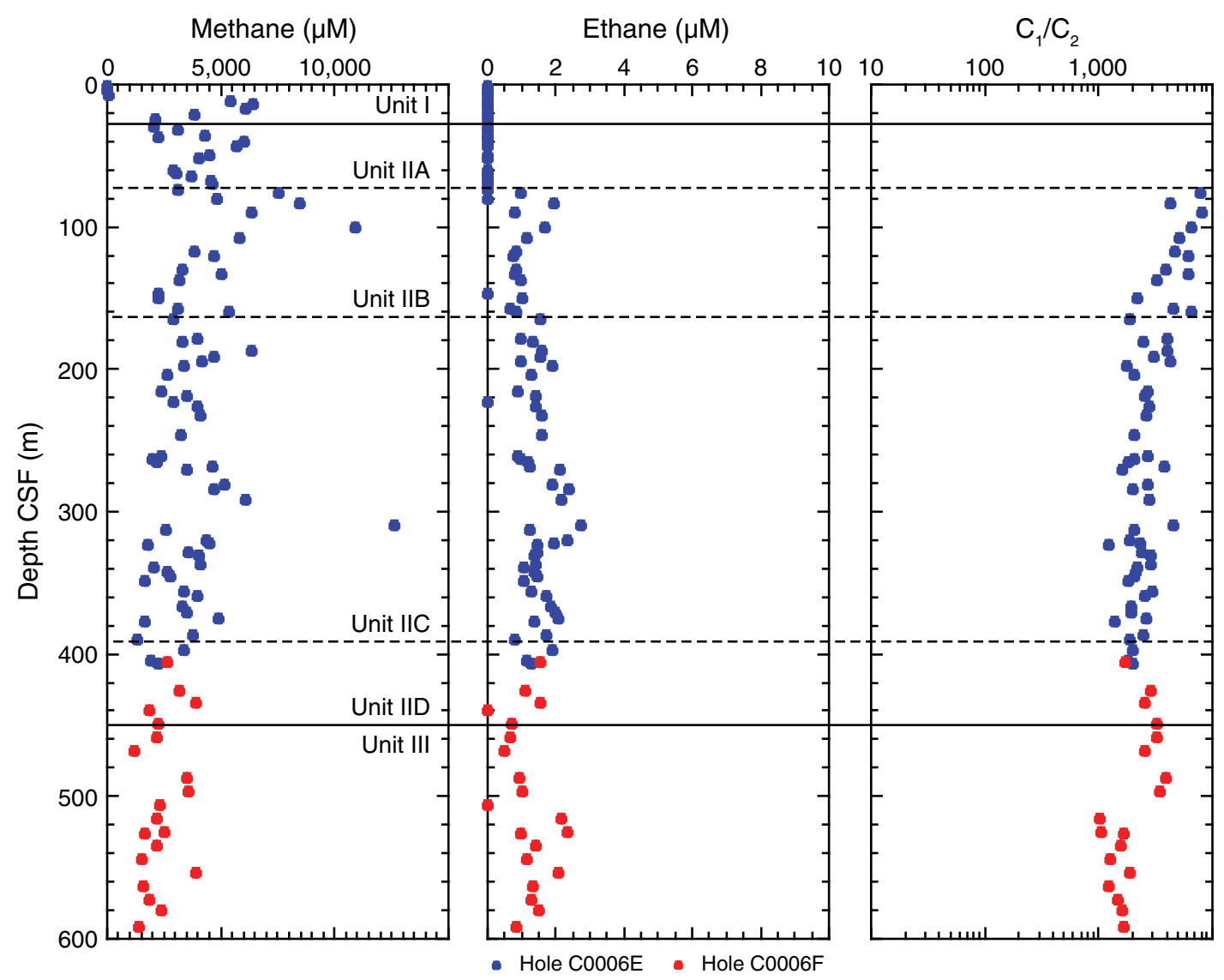


Figure F45. Calcium carbonate $\left(\mathrm{CaCO}_{3}\right)$, total organic carbon (TOC), total nitrogen (TN), carbon to nitrogen (C/N) ratio, and total sulfur (TS) in sediments, Site C0006. CSF = core depth below seafloor.

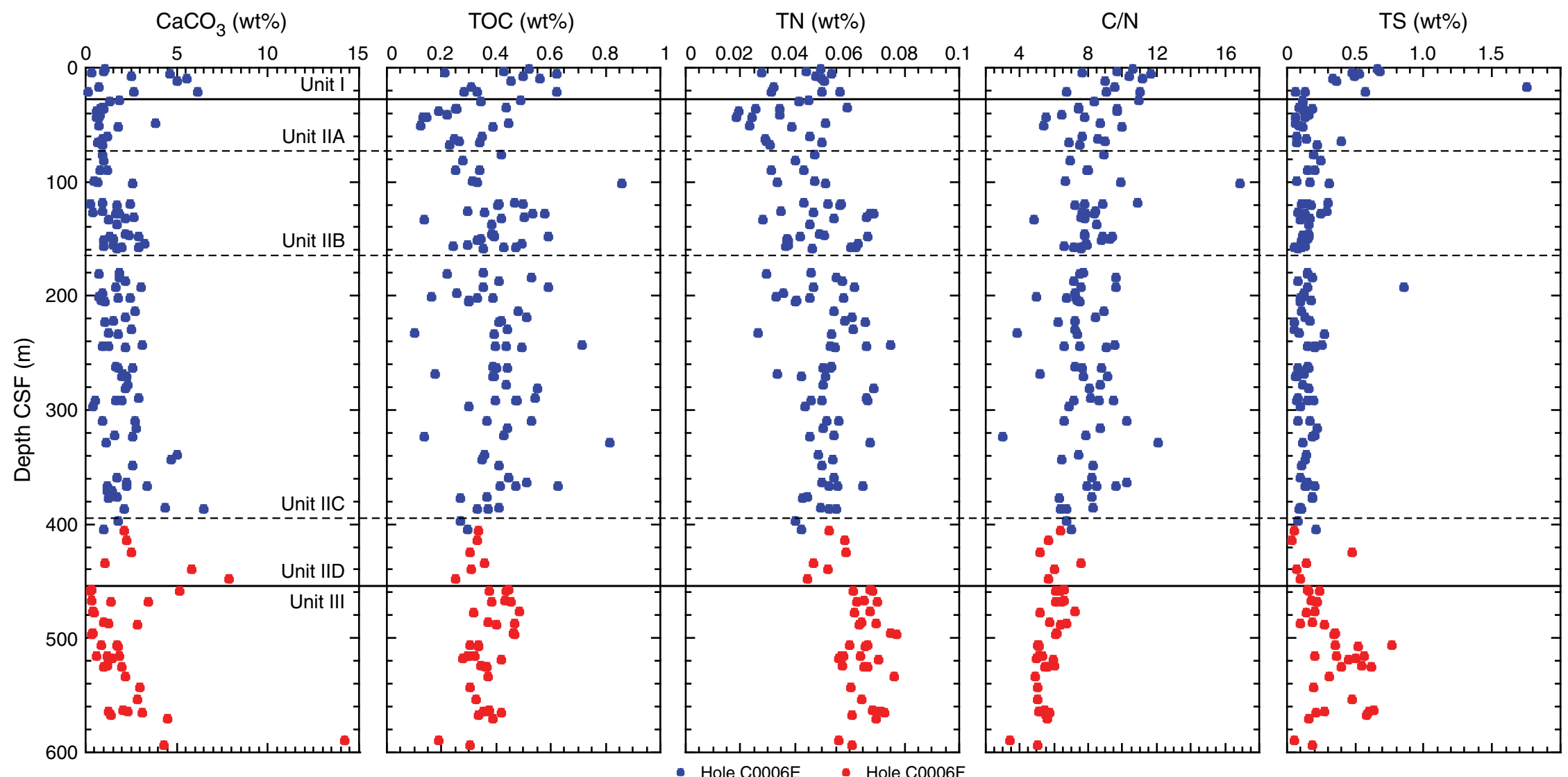


Figure F46. Microbial cell abundance enumerated by microscopic direct count of SYBR Green I-stained cells, Site C0006. CSF = core depth below seafloor.

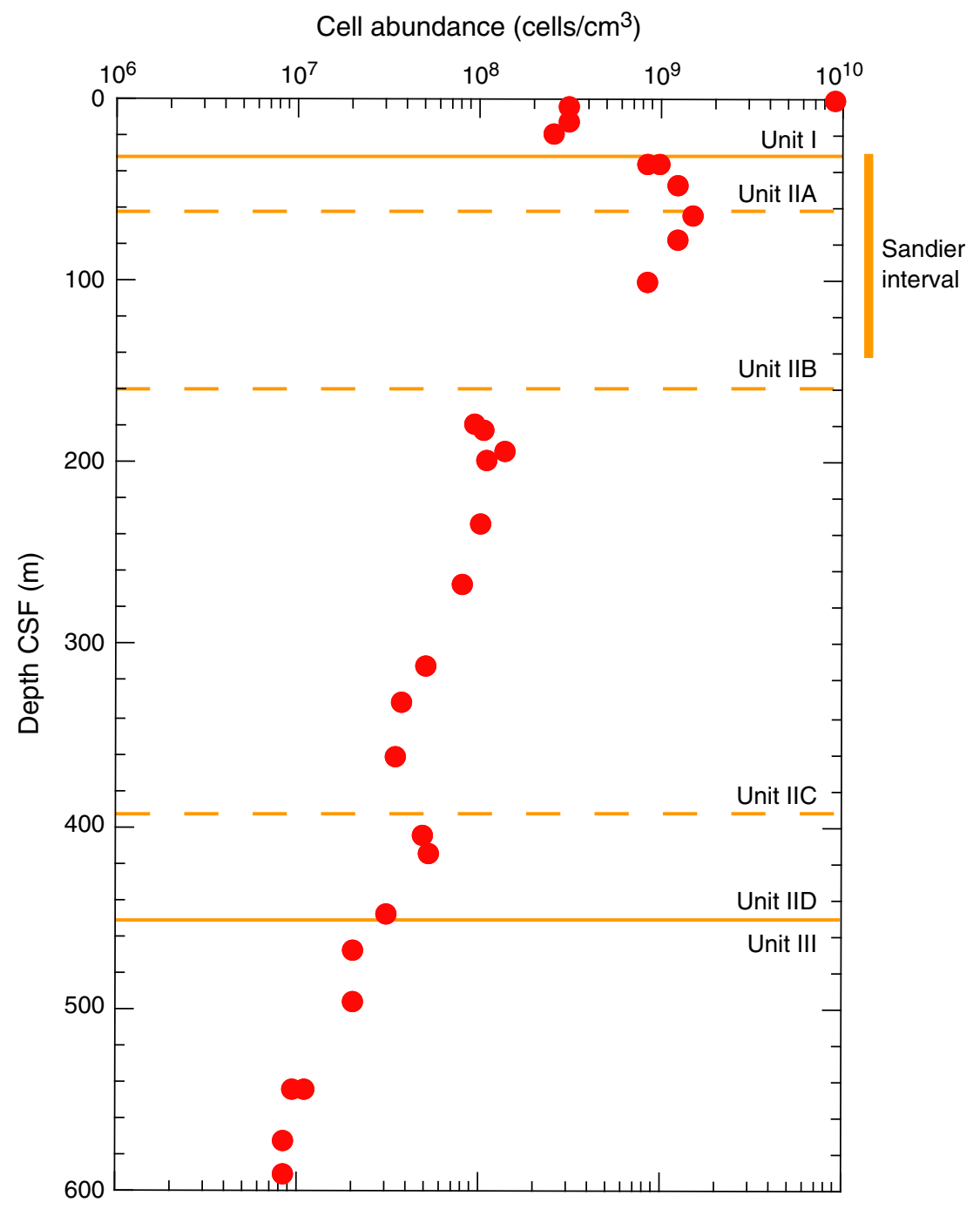


Figure F47. Fluorescent microscopic image of SYBR Green I-stained cells detected from the accretionary prism close to the lithologic Unit II/III boundary (Section 316-C0006F-3R-2; $414.5 \mathrm{~m} \mathrm{CSF}$ ).

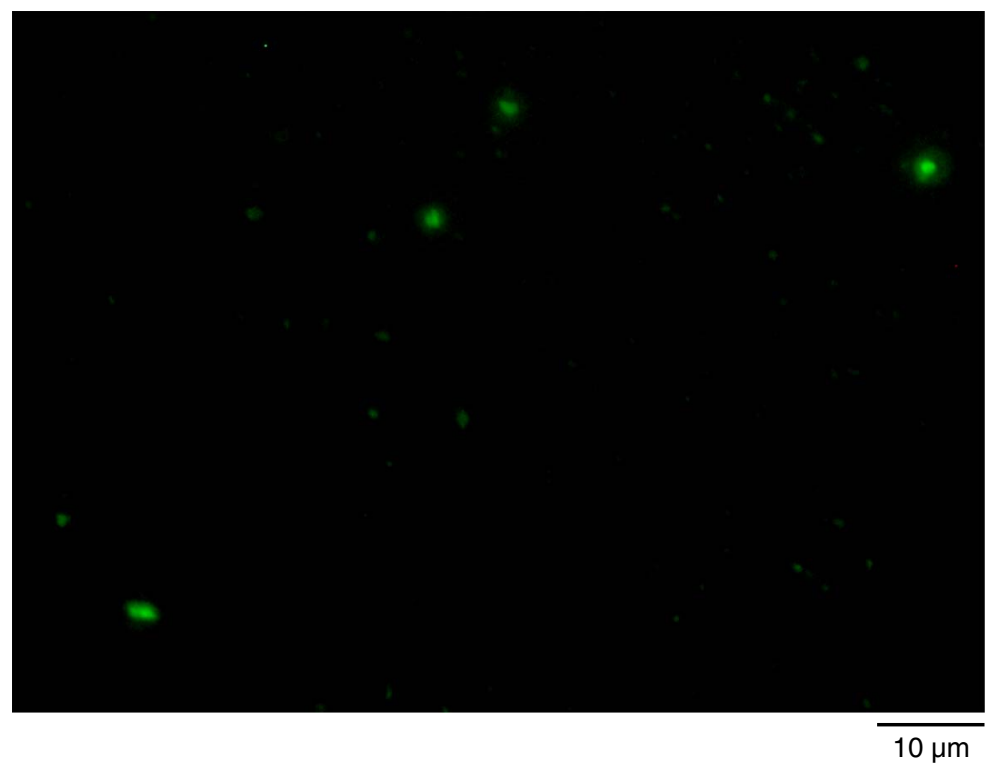


Figure F48. Density and porosity measurement results, Holes C0006C, C0006D, C0006E, and C0006F. A. Gamma ray attenuation (GRA) density measured using a multisensor core logger (MSCL) system on whole-round core sections (gray dots) and wet bulk density measured on discrete samples using MAD methods (red dots). B. Grain density measured on discrete samples using MAD methods. C. MSCL-derived porosity (gray dots) and MAD porosity (red dots). CSF = core depth below seafloor.

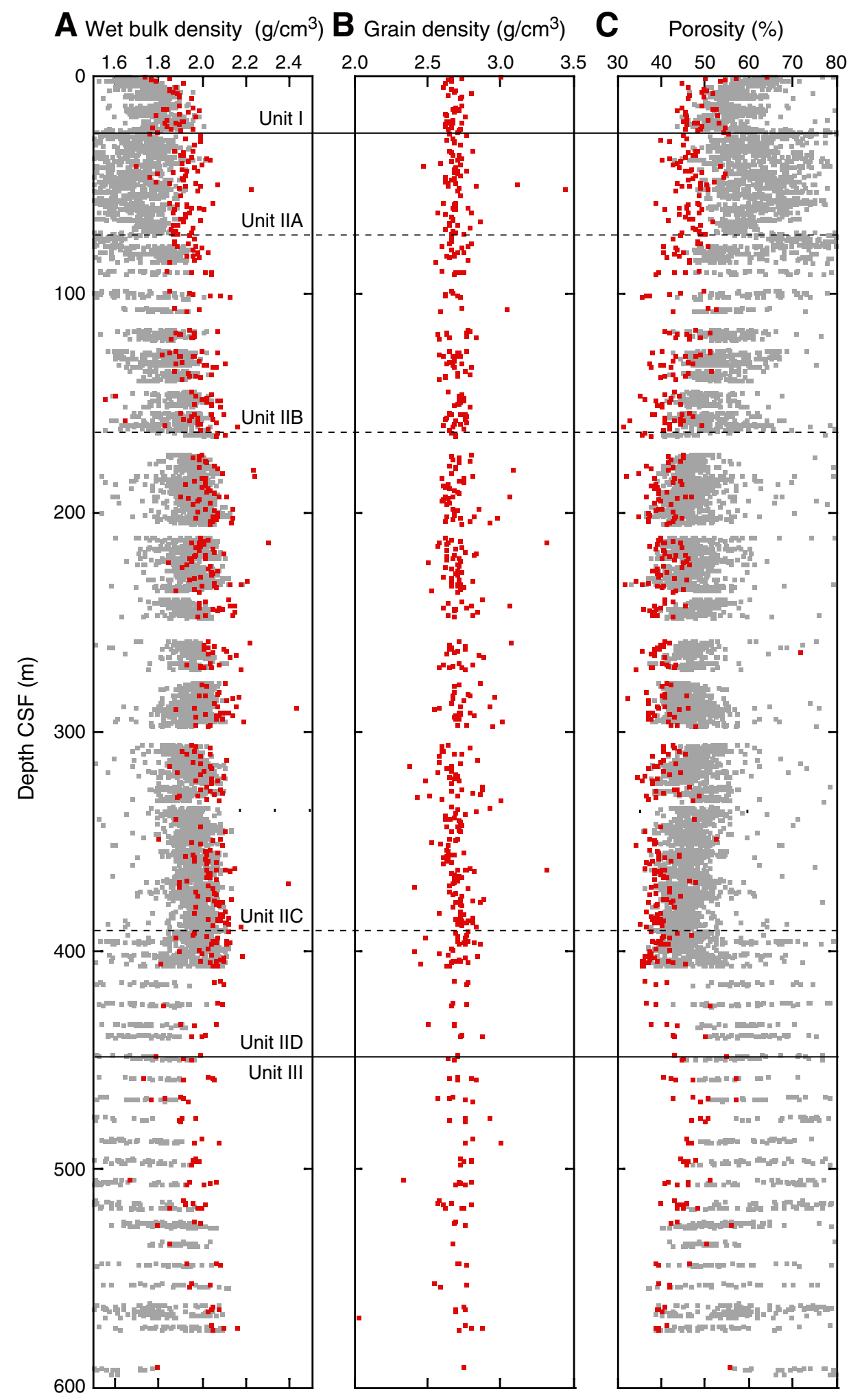


Figure F49. Measurements on discrete samples. A. $P$-wave velocity. B. $P$-wave velocity anisotropy. C. Electrical conductivity. Black cross $=$ individual measurement, black square $=$ measurement along core axis, red square $=$ average conductivity per sample, green line $=$ LWD bit conductivity data for comparison. D. Electrical conductivity anisotropy. For transverse anisotropy, positive values equal lower magnitude along core axis. CSF $=$ core depth below seafloor.

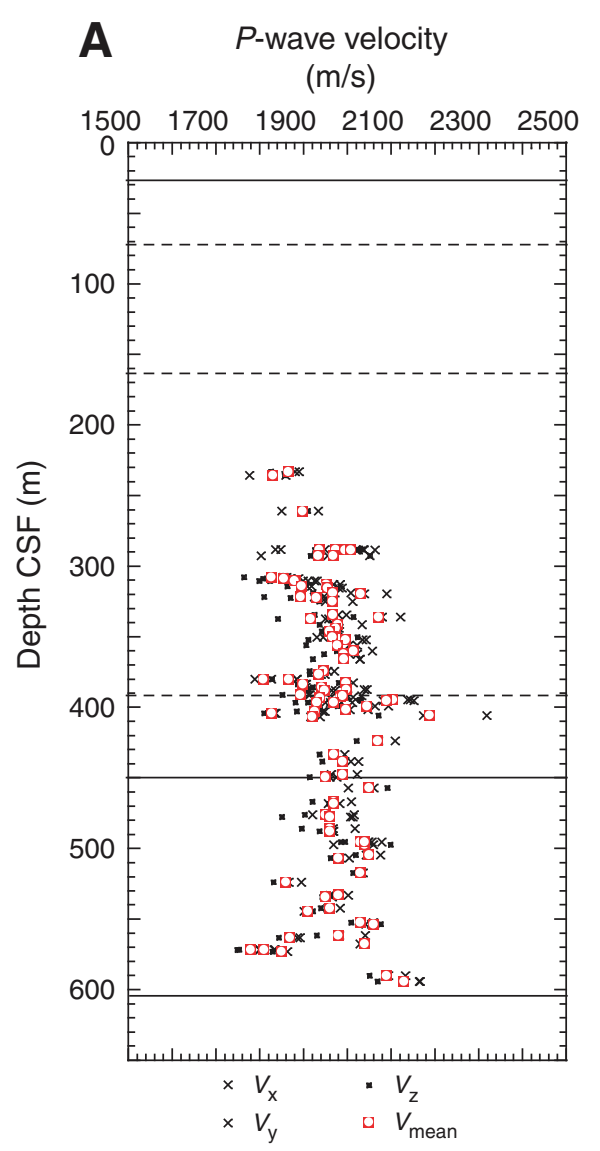

B $\quad P$-wave velocity anisotropy (\%)

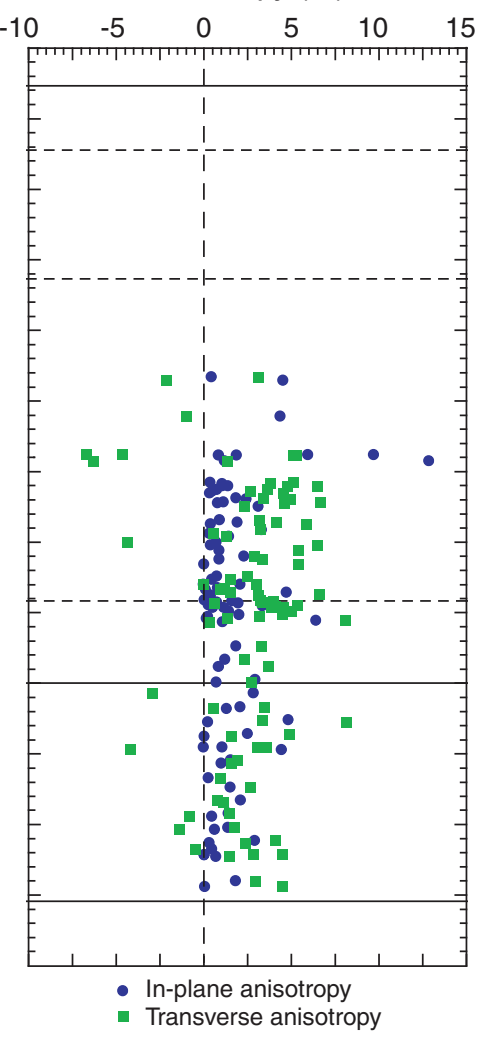

C Electrical conductivity

$$
(\mathrm{S} / \mathrm{m})
$$

$\begin{array}{llllllll}0 & 0.2 & 0.4 & 0.6 & 0.8 & 1.0 & 1.2 & 1.4\end{array}$

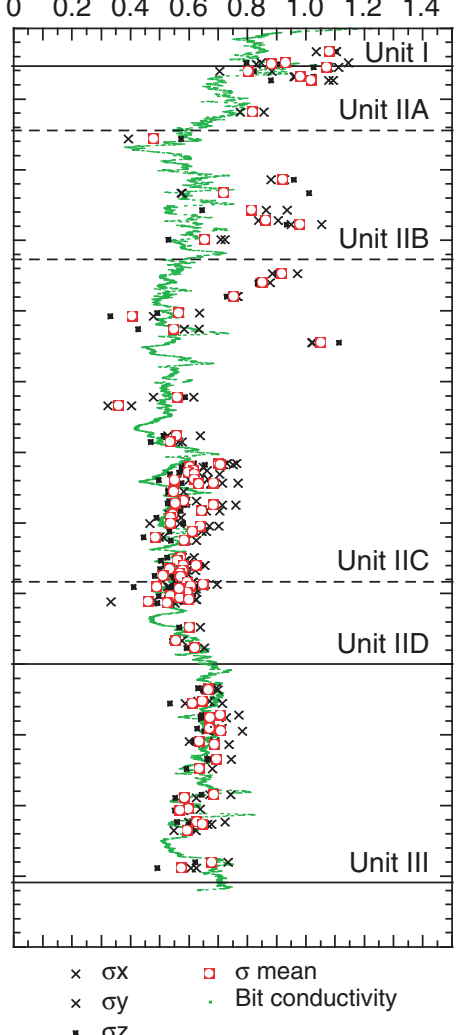

D

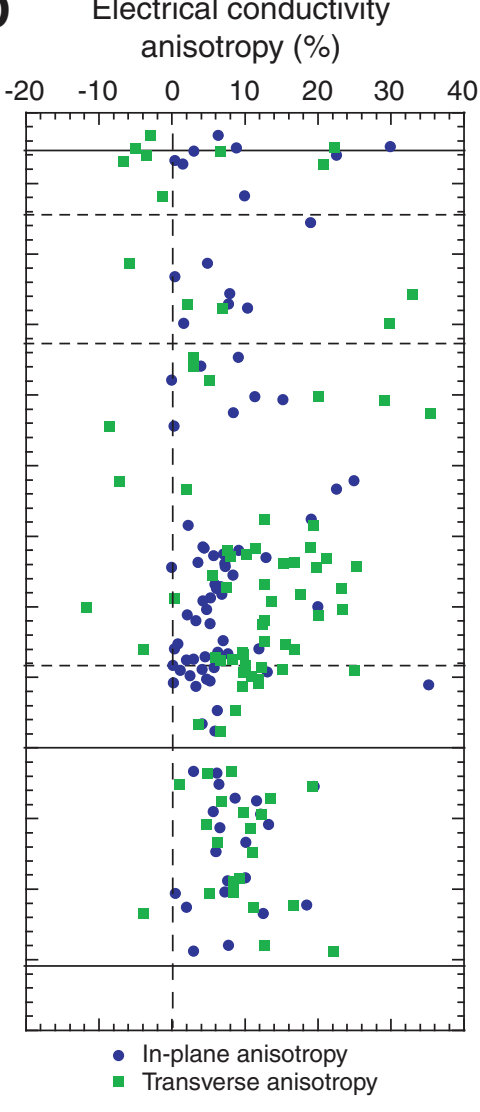


Figure F50. Thermal data, Site C0006. A. Thermal conductivity. B. Equilibrium temperatures (circles) and projected temperatures (line). Best-fit linear gradient to the equilibrium temperature is $27^{\circ} \mathrm{C} / \mathrm{km}$. C. Temperature as a function of thermal resistance. Best-fit slope gives a heat flow value of $33 \mathrm{~mW} / \mathrm{m}^{2}$ and a bottom water temperature of $2.1^{\circ} \mathrm{C}$. CSF $=$ core depth below seafloor.

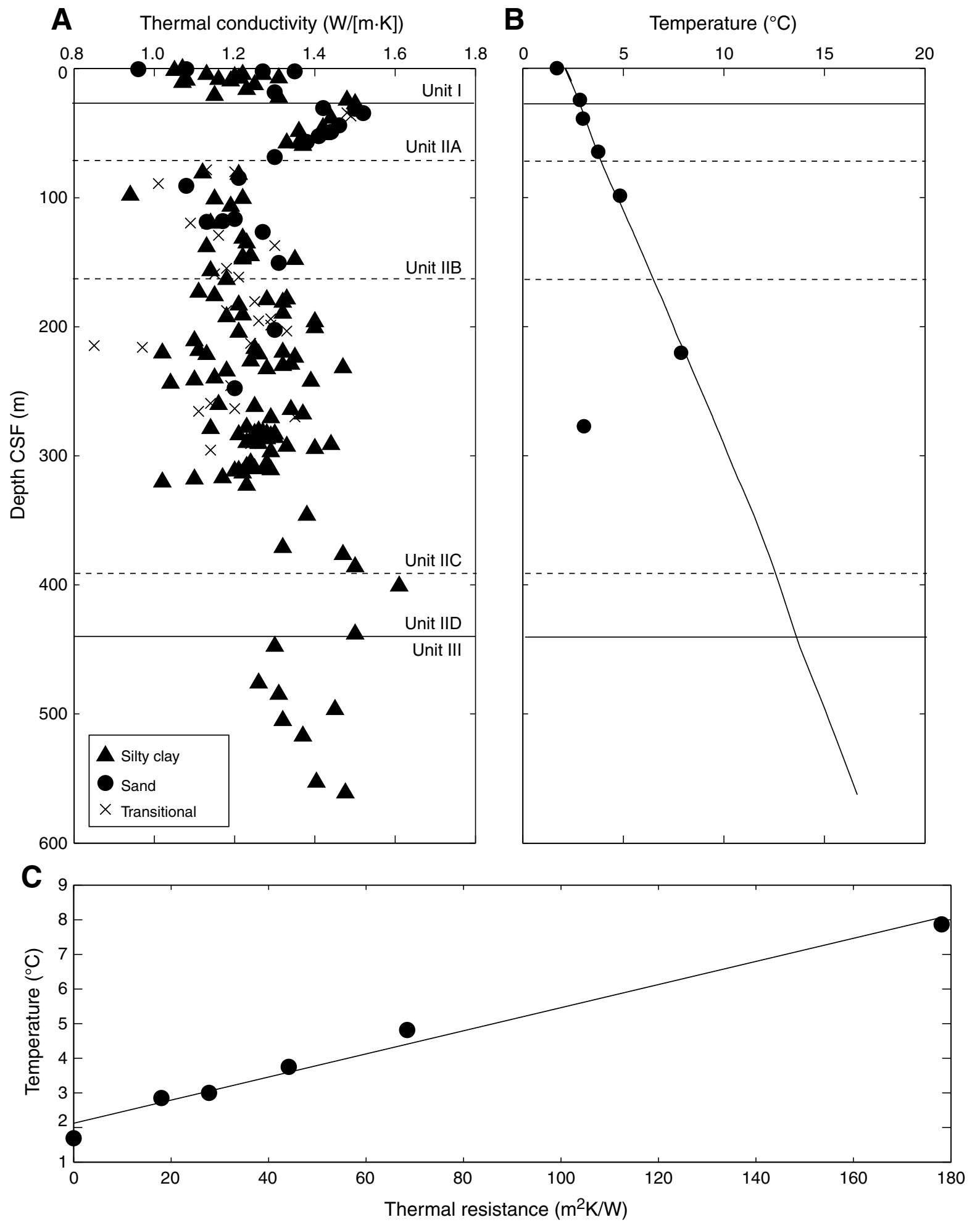


Figure F51. Temperature time series (blue line), Site C0006. APCT3 measurements at (A) $24.2 \mathrm{~m}$ CSF, (B) 38.5 $\mathrm{m} \mathrm{CSF}$, and (C) $64.7 \mathrm{~m} \mathrm{CSF}$. Unshaded area = data used for equilibrium temperature fit, red line $=$ theoretical equilibrium curve, triangle $=$ beginning of fit, inverted triangle $=$ end of fit, dashed red line with circles $=$ estimate of equilibrium temperature. Note frictional heating at penetration (dashed vertical line) and at pull out. (Continued on next page.)
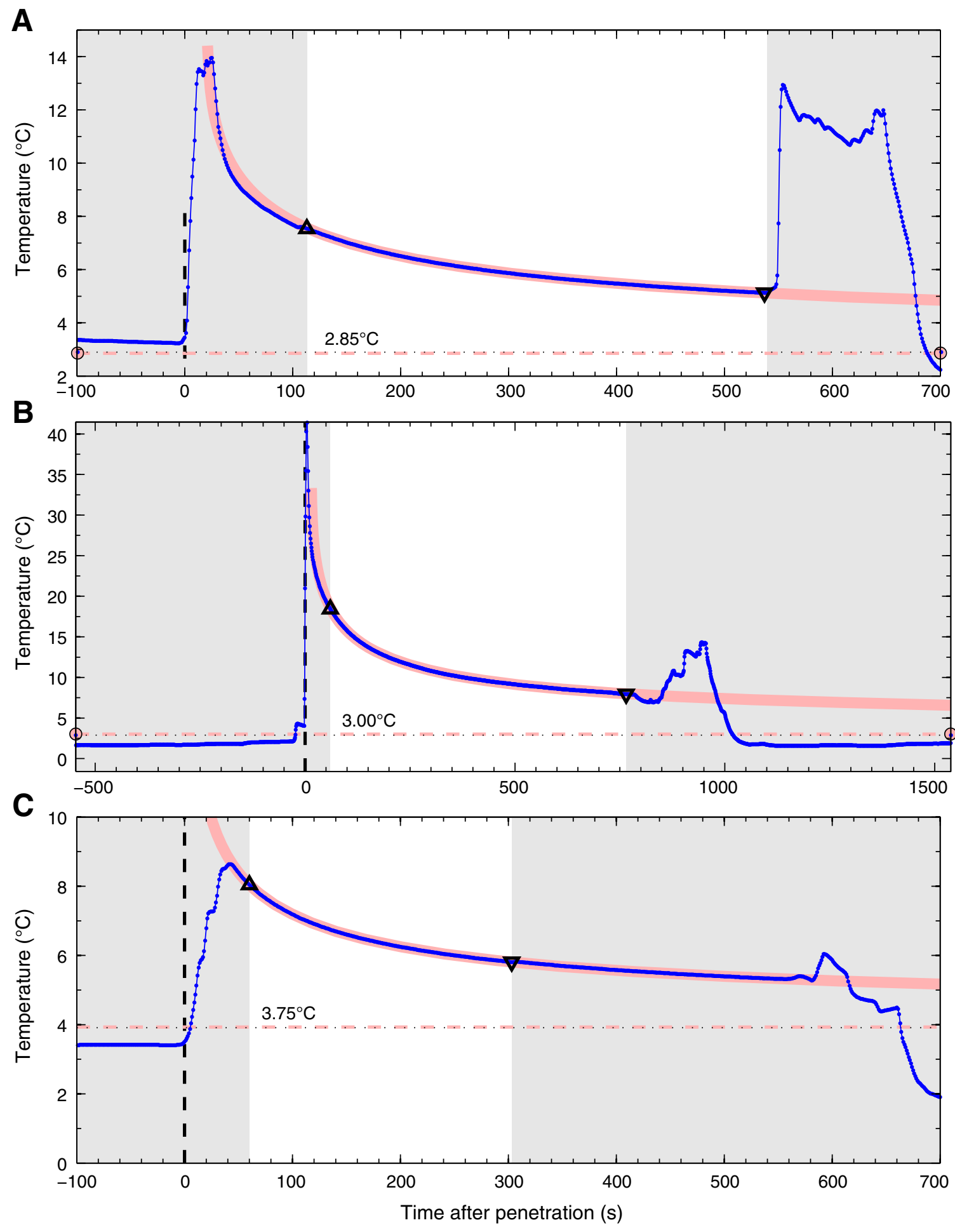
Figure F51 (continued). DVTP measurements at (D) $98.3 \mathrm{~m} \mathrm{CSF}$, (E) $220.3 \mathrm{~m} \mathrm{CSF}$, and (F) $277.3 \mathrm{~m} \mathrm{CSF}$.
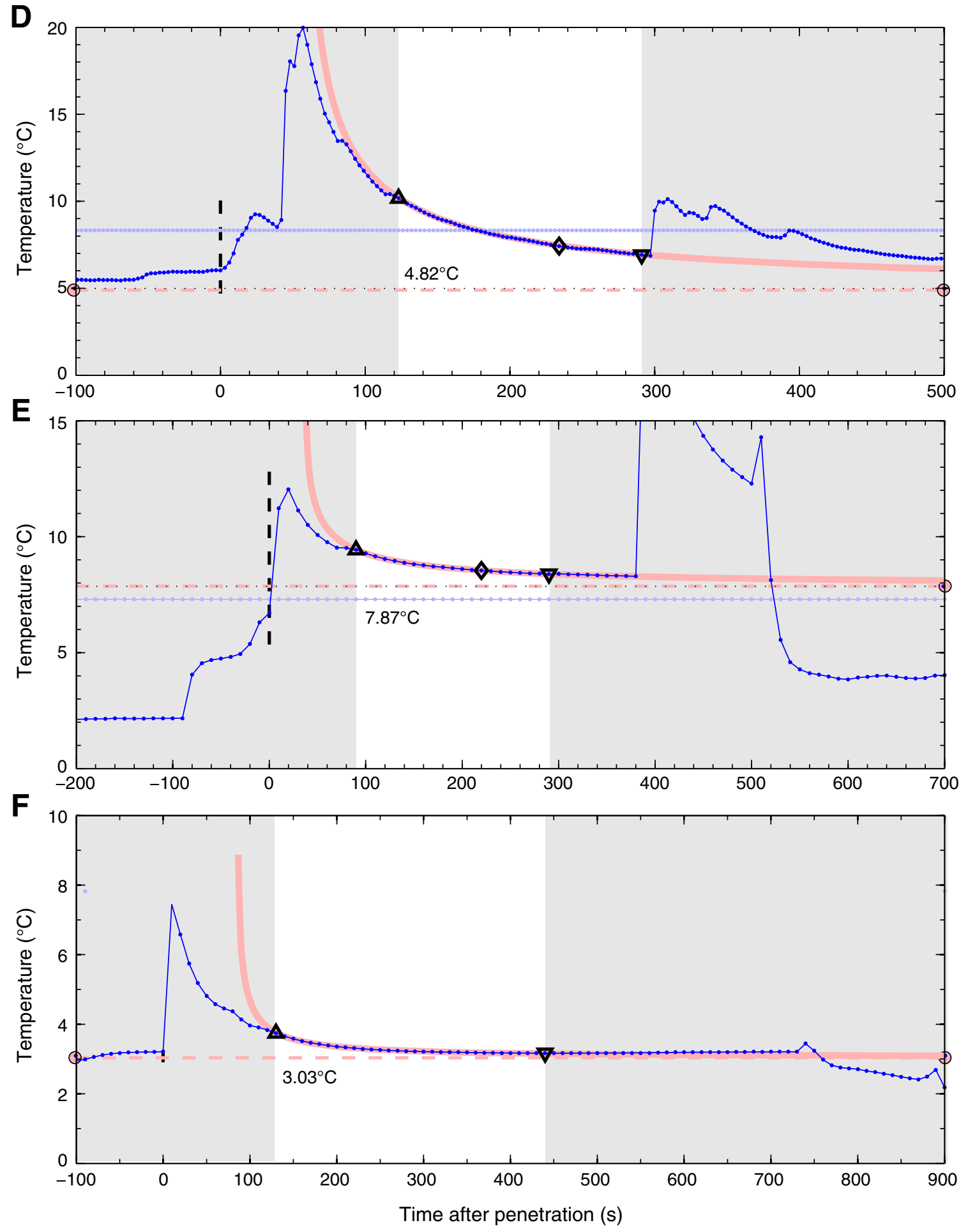
Figure F52. Shear strength measurements from Site C0006 show a general increase with depth with low values corresponding to Subunit IIA and a marked increase at the boundary with Subunit IIB. Penetrometer measurements are consistently higher than those measured with the vane shear apparatus. CSF $=$ core depth below seafloor.

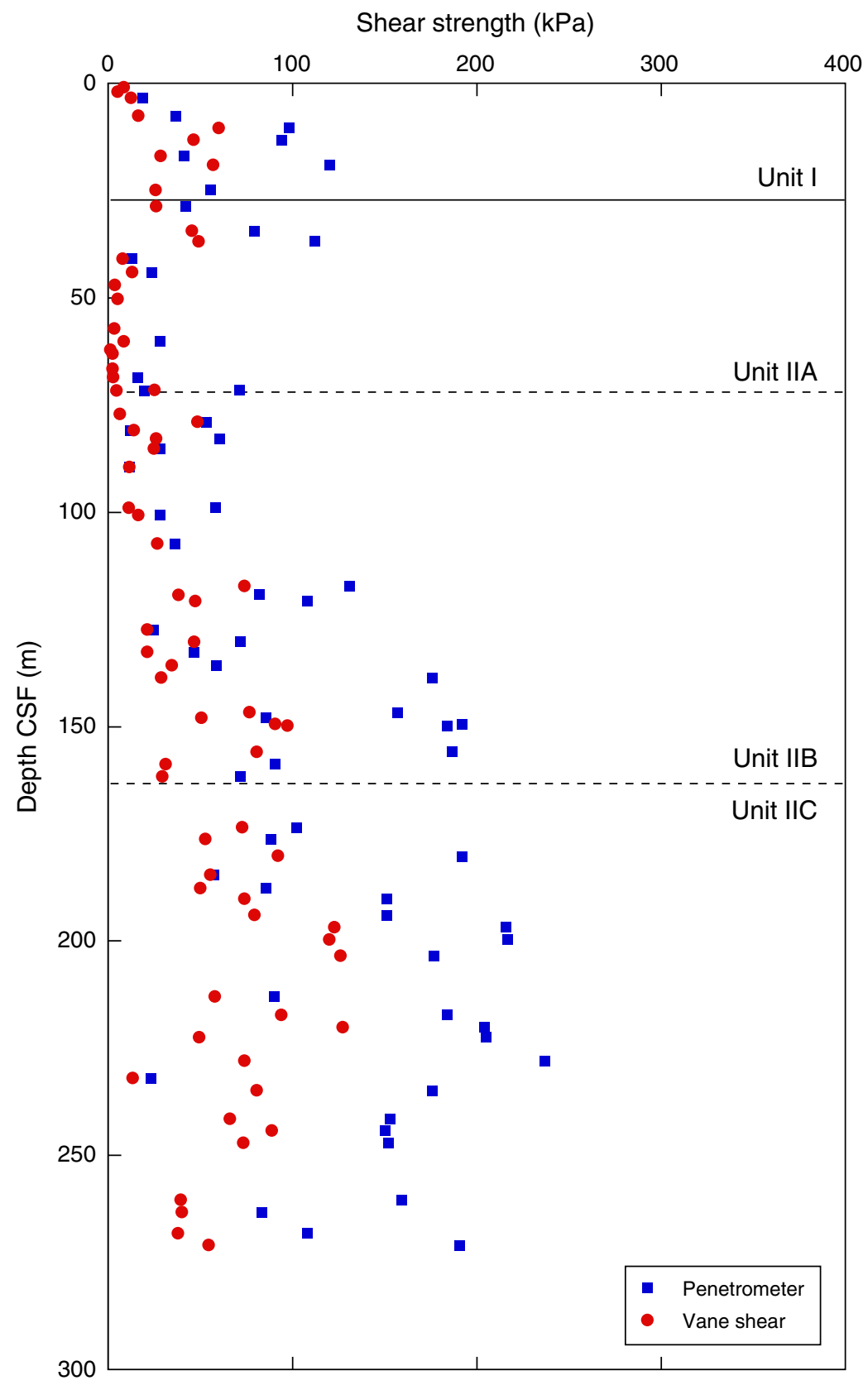


Figure F53. $\mathrm{L}^{*}, \mathrm{a}^{*}$, and $\mathrm{b}^{*}$ values with depth, Site C0006. CSF $=$ core depth below seafloor.
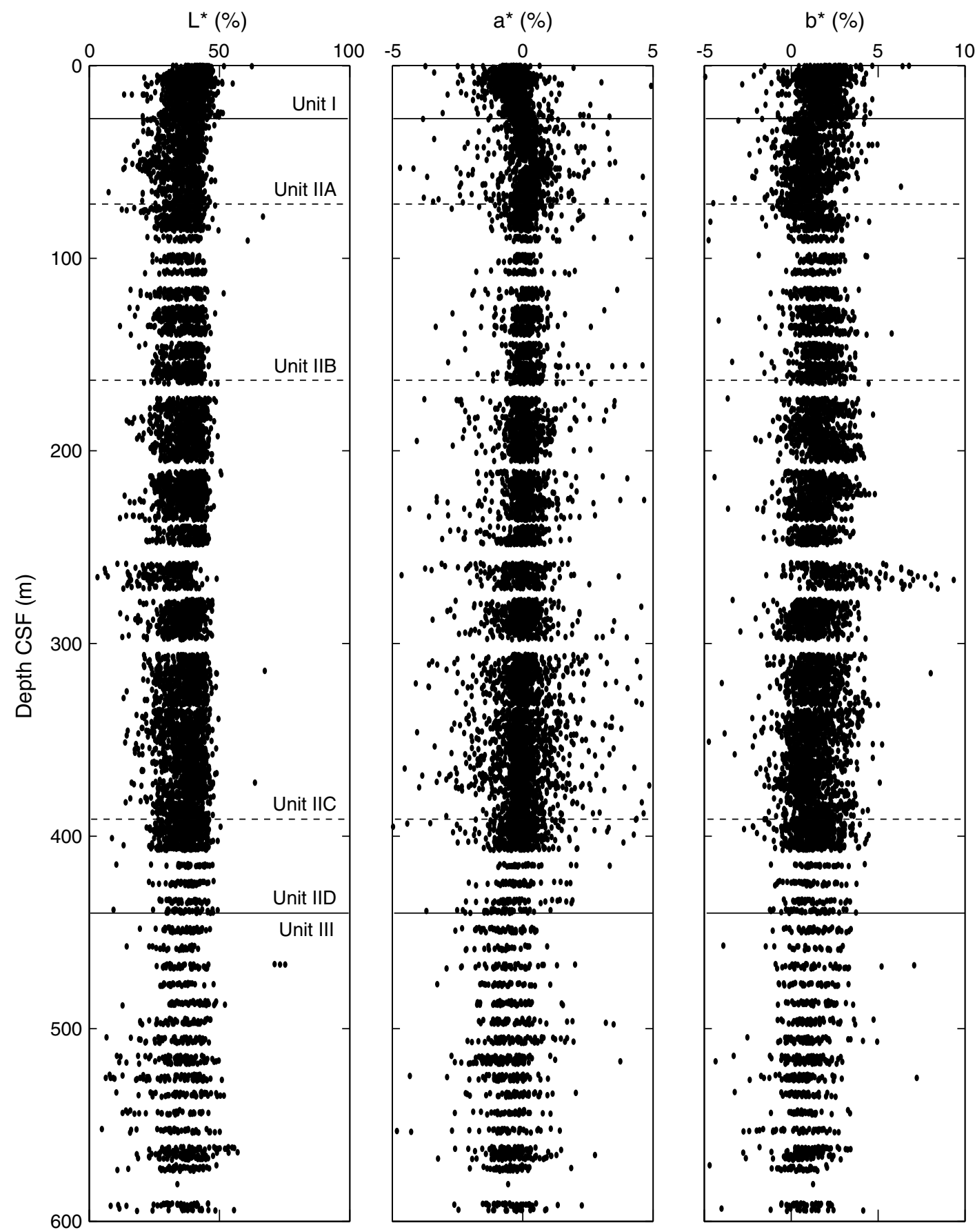
Figure F54. Magnetic susceptibility as a function of depth, Site C0006. CSF = core depth below seafloor.

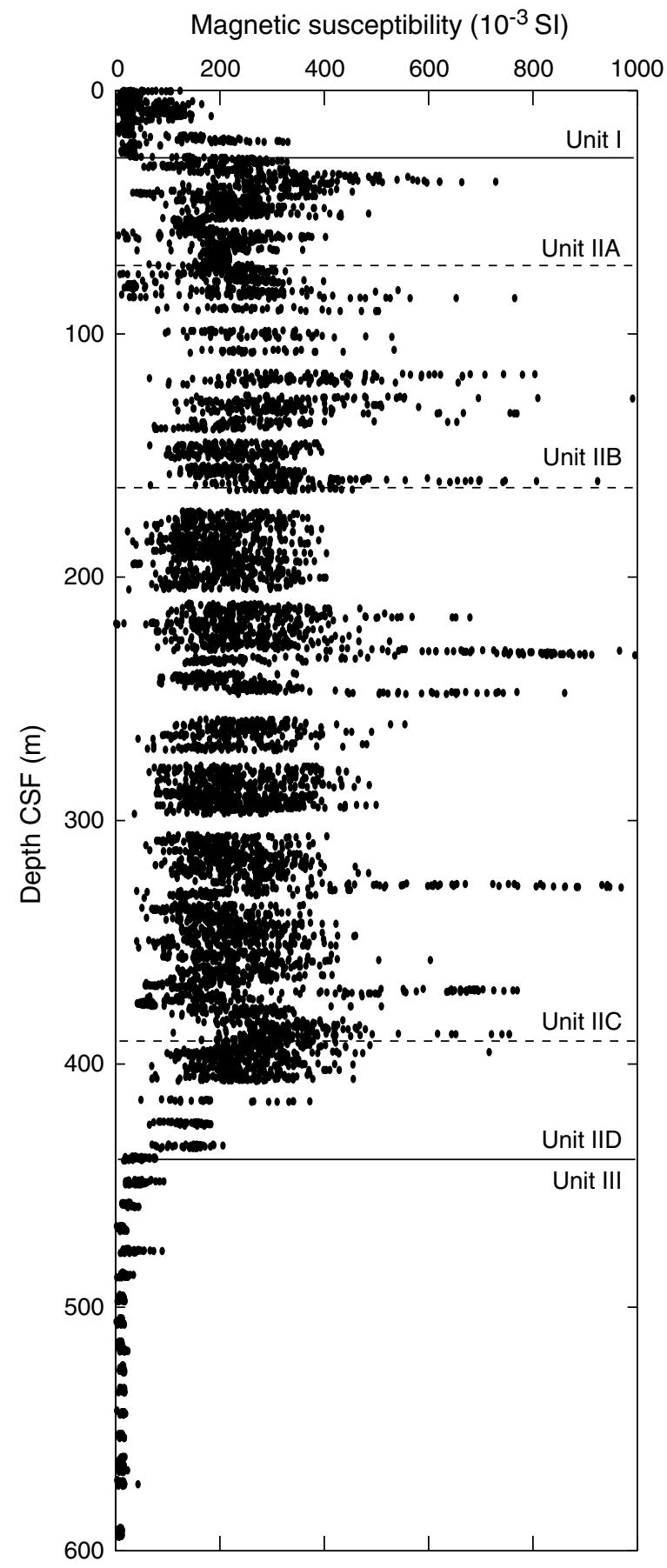


Figure F55. Natural gamma ray (NGR) values with depth, Site C0006. CSF $=$ core depth below seafloor. $\mathrm{cps}=$ counts per second.

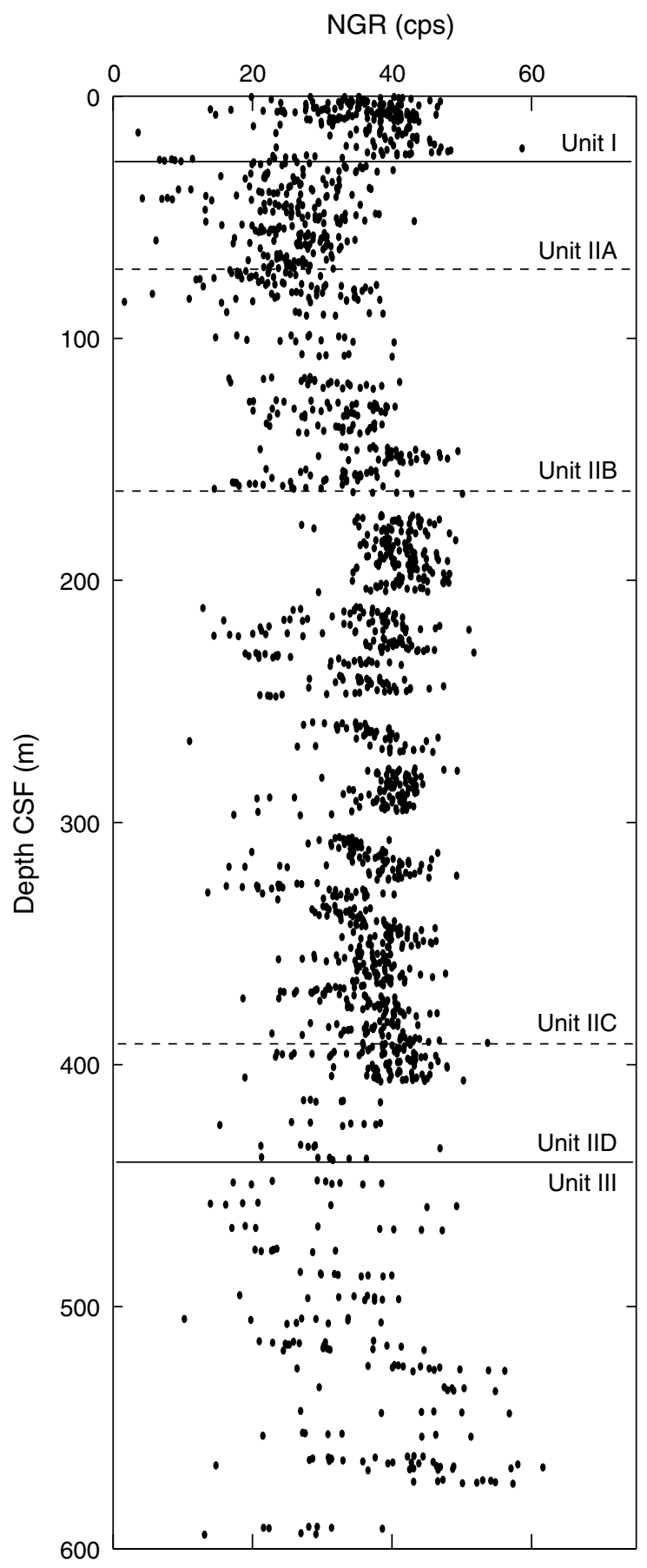


Figure F56. Correlations between all holes, Site C0006. A. Correlations between LWD data from Hole C0006B and MSCL-W data from Holes C0006E and C0006F. Numbers below holes are water depth (meters below mean sea level). Correlation positions are given in Table T21. CSF = core depth below seafloor. NGR = natural gamma ray, GR_RAB = gamma ray resistivity at the bit, sonic = sonic velocity. (Continued on next page.)

A

Hole CO006E
Depth CSF $(\mathrm{m})$ NGR $3875.8 \mathrm{~m} \quad V_{P}$

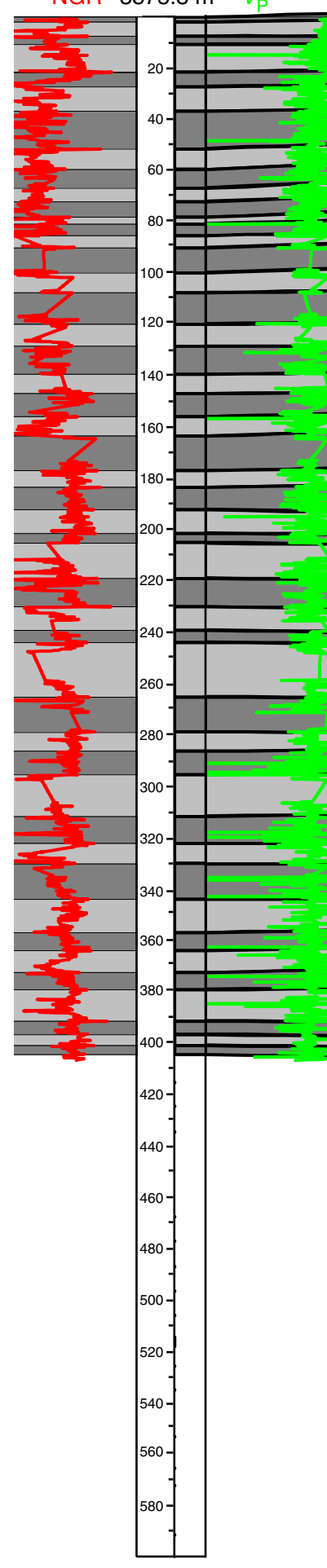

Hole C0006B

Depth CSF $(\mathrm{m})$

GR_RAB $3871.5 \mathrm{~m}$ Sonic

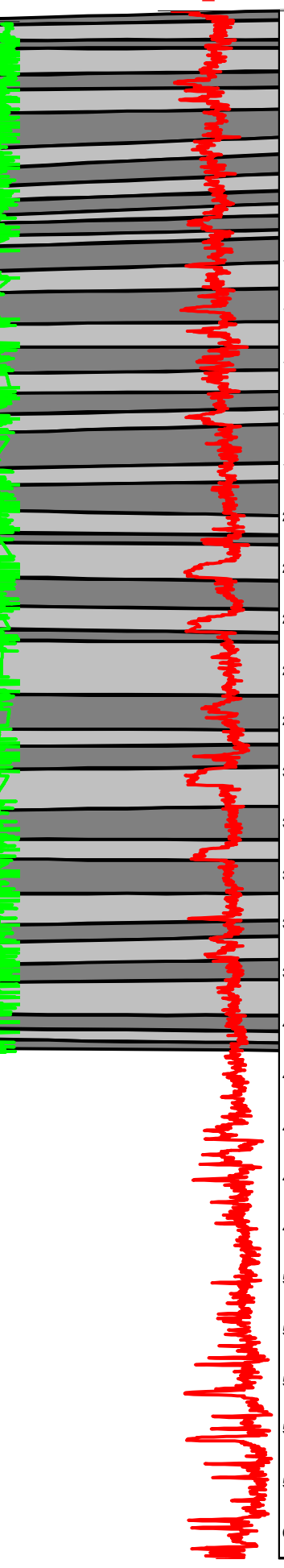

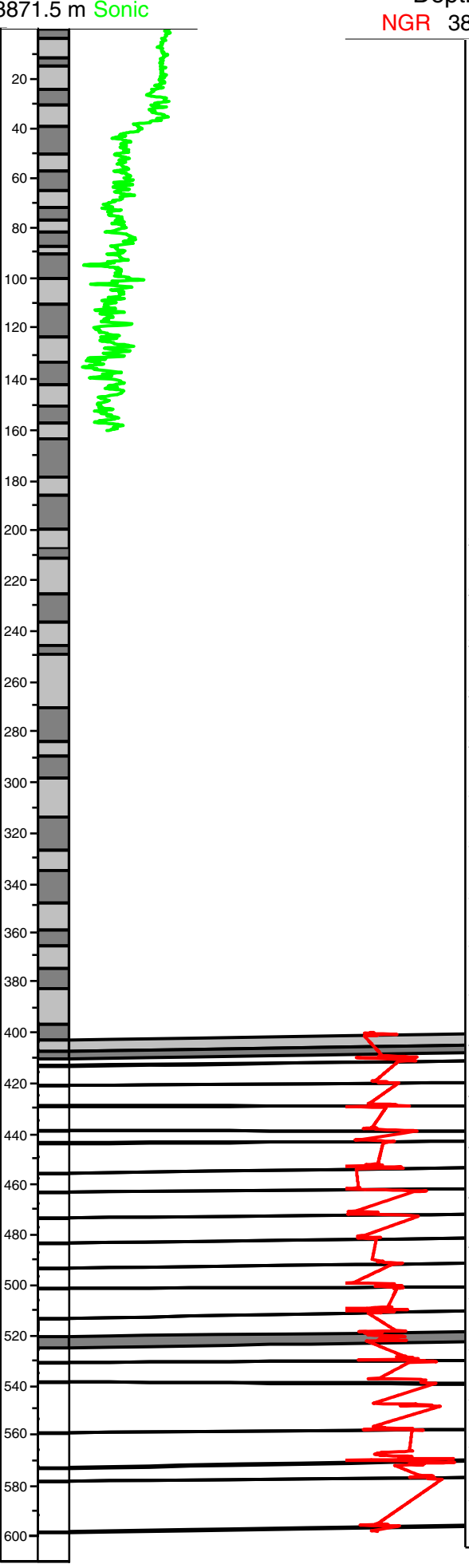

Hole C0006F

Depth CSF $(\mathrm{m})$

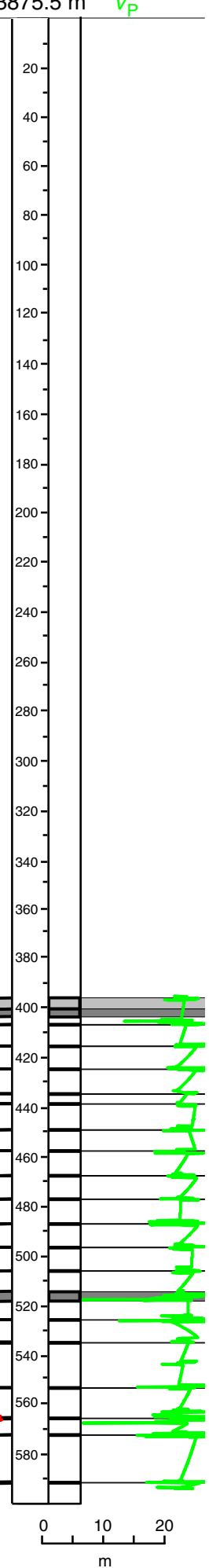


Figure F56 (continued). B. Correlations of MSCL-W data from Holes C0006C, C0006D, and C0006E.

B

Hole C0006E

Depth CSF $(m)$

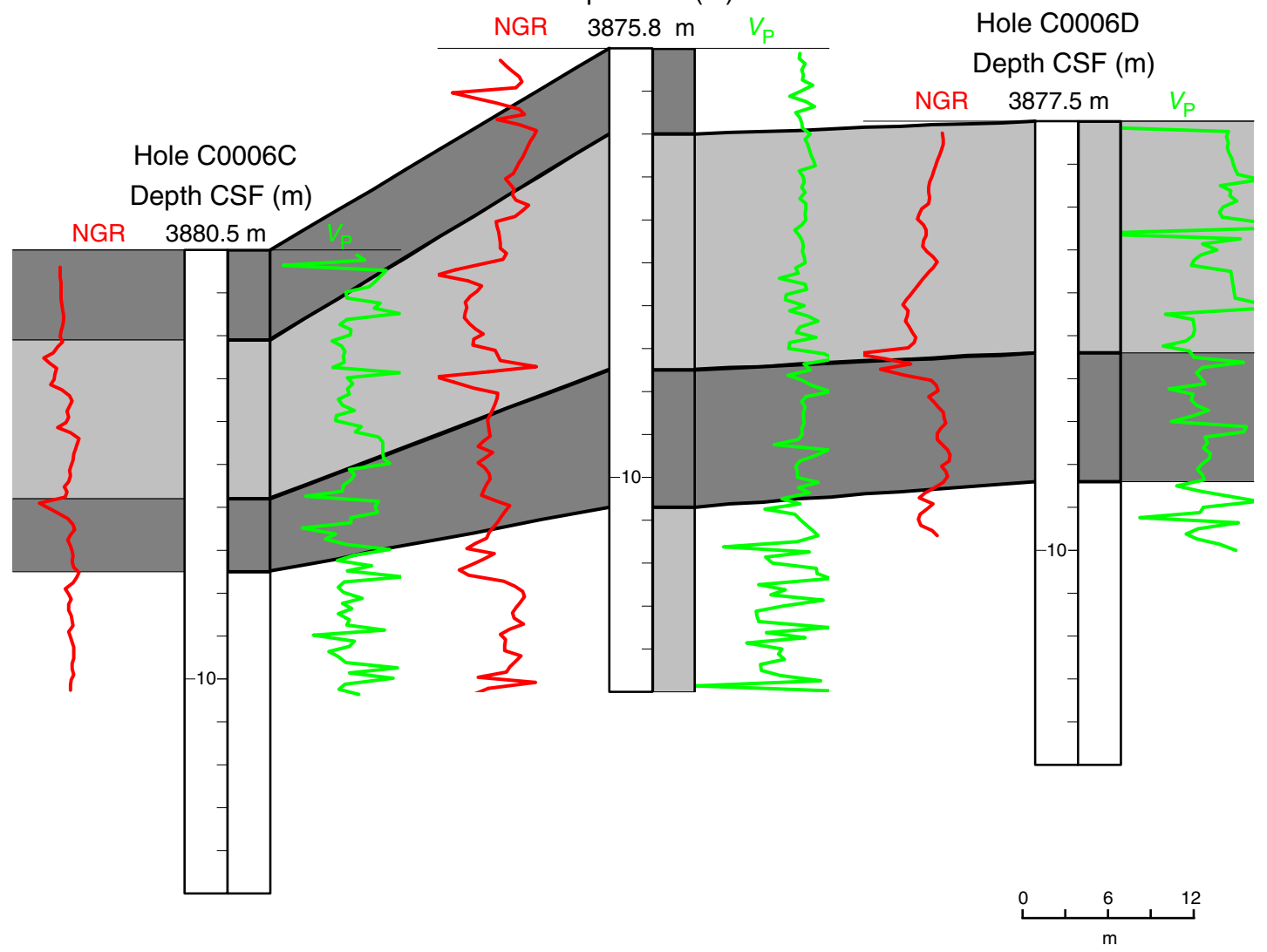


Table T1. Coring summary, Holes C0006C, C0006D, and C0006E. (See table note.) (Continued on next page.)

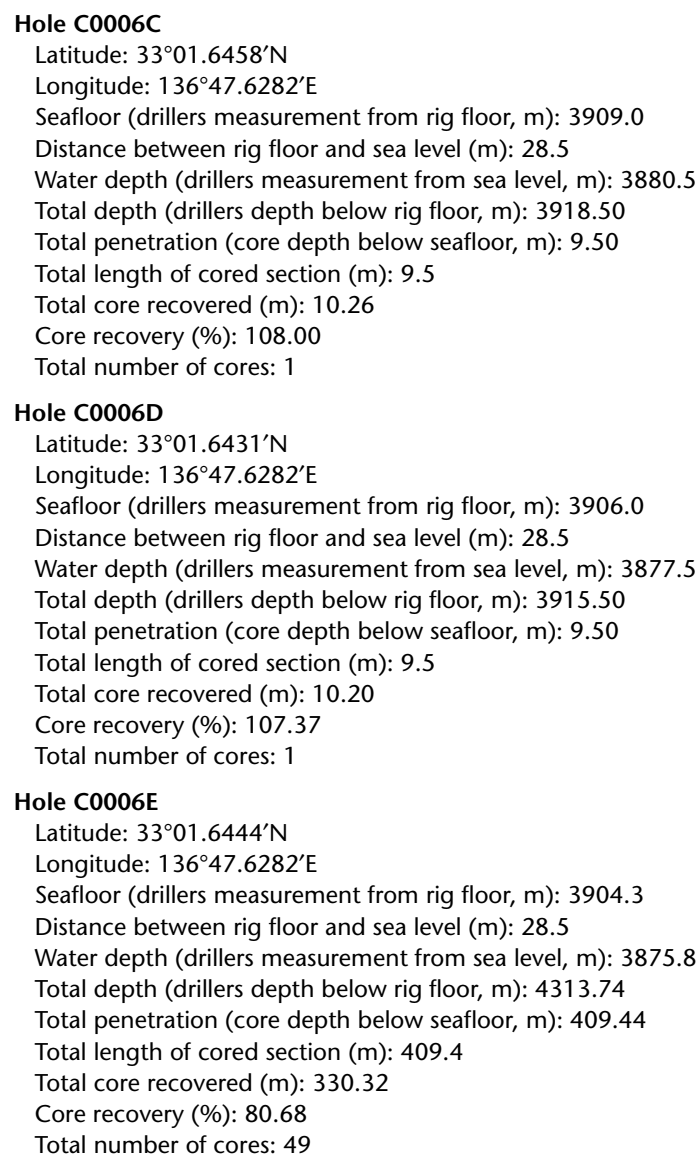

\begin{tabular}{|c|c|c|c|c|c|c|c|c|c|c|}
\hline \multirow[b]{2}{*}{ Core } & \multirow[b]{2}{*}{ Date } & \multicolumn{2}{|c|}{ Local time } & \multicolumn{2}{|c|}{ Depth DRF $(m)$} & \multicolumn{2}{|c|}{ Depth CSF (m) } & \multirow{2}{*}{$\begin{array}{l}\text { Advanced } \\
\text { (m) }\end{array}$} & \multirow{2}{*}{$\begin{array}{l}\text { Recovered } \\
(\mathrm{m})\end{array}$} & \multirow{2}{*}{$\begin{array}{c}\text { Recovery } \\
\text { (\%) }\end{array}$} \\
\hline & & Shot & On deck & Top & Bottom & Top & Bottom & & & \\
\hline \multicolumn{11}{|c|}{ 316-C0006C- } \\
\hline $1 \mathrm{H}$ & 28 Dec 2007 & 1812 & 1846 & 3909.00 & 3918.50 & 0.00 & 9.50 & 9.50 & 10.26 & 108.00 \\
\hline \multicolumn{11}{|c|}{ 316-C0006D- } \\
\hline $1 \mathrm{H}$ & 28 Dec 2007 & 1951 & 2200 & 3906.00 & 3915.50 & 0.00 & 9.50 & 9.50 & 10.20 & 107.37 \\
\hline \multicolumn{11}{|c|}{ 316-C0006E- } \\
\hline $1 \mathrm{H}$ & 28 Dec 2007 & 2310 & 2337 & 3904.31 & 3909.50 & 0.00 & 5.19 & 5.19 & 5.90 & 113.68 \\
\hline $2 \mathrm{H}$ & 29 Dec 2007 & 0026 & 0112 & 3909.50 & 3919.00 & 5.19 & 14.69 & 9.50 & 10.14 & 106.74 \\
\hline $3 \mathrm{H}$ & 29 Dec 2007 & 0205 & 0240 & 3919.00 & 3928.50 & 14.69 & 24.19 & 9.50 & 10.41 & 109.58 \\
\hline $4 \mathrm{H}$ & 29 Dec 2007 & 0354 & 0448 & 3928.50 & 3937.53 & 24.19 & 33.22 & 9.03 & 9.03 & 100.00 \\
\hline $5 \mathrm{H}$ & 29 Dec 2007 & 0708 & 0800 & 3937.53 & 3942.83 & 33.22 & 38.52 & 5.30 & 5.30 & 100.00 \\
\hline $6 \mathrm{H}$ & 29 Dec 2007 & 0902 & 1315 & 3942.83 & 3943.00 & 38.52 & 38.69 & 0.17 & 0.17 & 100.00 \\
\hline $7 \mathrm{H}$ & 29 Dec 2007 & 1955 & 2037 & 3943.00 & 3952.50 & 38.69 & 48.19 & 9.50 & 10.32 & 108.63 \\
\hline $8 \mathrm{H}$ & 29 Dec 2007 & 2154 & 2244 & 3952.50 & 3962.00 & 48.19 & 57.69 & 9.50 & 10.63 & 111.89 \\
\hline $9 \mathrm{H}$ & 30 Dec 2007 & 0003 & 0056 & 3962.00 & 3968.82 & 57.69 & 64.51 & 6.82 & 6.82 & 100.00 \\
\hline $10 \mathrm{H}$ & 30 Dec 2007 & 0307 & 0359 & 3968.82 & 3968.98 & 64.51 & 64.67 & 0.16 & 0.16 & 100.00 \\
\hline $11 \mathrm{H}$ & 30 Dec 2007 & 0523 & 0633 & 3968.98 & 3975.79 & 64.67 & 71.48 & 6.81 & 6.81 & 100.00 \\
\hline $12 \mathrm{H}$ & 30 Dec 2007 & 0756 & 0840 & 3975.79 & 3982.13 & 71.48 & 77.82 & 6.34 & 6.34 & 100.00 \\
\hline $13 \mathrm{H}$ & 30 Dec 2007 & 1001 & 1049 & 3982.13 & 3983.64 & 77.82 & 79.33 & 1.51 & 1.51 & 100.00 \\
\hline $14 \mathrm{H}$ & 30 Dec 2007 & 1225 & 1310 & 3983.64 & 3983.64 & 79.33 & 79.33 & 0.00 & 0.00 & 0.00 \\
\hline $15 X$ & 30 Dec 2007 & 1435 & 1548 & 3983.64 & 3993.14 & 79.33 & 88.83 & 9.50 & 5.80 & 61.05 \\
\hline $16 X$ & 30 Dec 2007 & 1643 & 1730 & 3993.14 & 4002.64 & 88.83 & 98.33 & 9.50 & 2.03 & 21.37 \\
\hline $17 X$ & 30 Dec 2007 & 2135 & 2225 & 4002.64 & 4010.64 & 98.33 & 106.33 & 8.00 & 3.63 & 45.38 \\
\hline $18 \mathrm{X}$ & 30 Dec 2007 & 2327 & 0022 & 4010.64 & 4020.14 & 106.33 & 115.83 & 9.50 & 1.66 & 17.47 \\
\hline $19 x$ & 31 Dec 2007 & 0057 & 0157 & 4020.14 & 4029.64 & 115.83 & 125.33 & 9.50 & 5.15 & 54.21 \\
\hline $20 x$ & 31 Dec 2007 & 0240 & 0325 & 4029.64 & 4039.14 & 125.33 & 134.83 & 9.50 & 7.88 & 82.95 \\
\hline $21 X$ & 1 Jan 2008 & 1617 & 1711 & 4039.14 & 4048.64 & 134.83 & 144.33 & 9.50 & 4.78 & 50.32 \\
\hline $22 \mathrm{X}$ & 1 Jan 2008 & 1825 & 1923 & 4048.64 & 4058.14 & 144.33 & 153.83 & 9.50 & 7.30 & 76.84 \\
\hline $23 x$ & 1 Jan 2008 & 2005 & 2058 & 4058.14 & 4067.64 & 153.83 & 163.33 & 9.50 & 8.53 & 89.79 \\
\hline $24 X$ & $2 \operatorname{Jan} 2008$ & 0427 & 0515 & 4067.64 & 4077.14 & 163.33 & 172.83 & 9.50 & 1.55 & 16.32 \\
\hline
\end{tabular}


Table T1 (continued).

\begin{tabular}{|c|c|c|c|c|c|c|c|c|c|c|}
\hline \multirow[b]{2}{*}{ Core } & \multirow[b]{2}{*}{ Date } & \multicolumn{2}{|c|}{ Local time } & \multicolumn{2}{|c|}{ Depth DRF (m) } & \multicolumn{2}{|c|}{ Depth CSF (m) } & \multirow{2}{*}{$\begin{array}{l}\text { Advanced } \\
(\mathrm{m})\end{array}$} & \multirow{2}{*}{$\begin{array}{l}\text { Recovered } \\
\text { (m) }\end{array}$} & \multirow{2}{*}{$\begin{array}{c}\text { Recovery } \\
\text { (\%) }\end{array}$} \\
\hline & & Shot & On deck & Top & Bottom & Top & Bottom & & & \\
\hline $25 x$ & $2 \operatorname{Jan} 2008$ & 0705 & 0758 & 4077.14 & 4086.64 & 172.83 & 182.33 & 9.50 & 9.07 & 95.47 \\
\hline $26 X$ & 2 Jan 2008 & 1108 & 1335 & 4086.64 & 4096.14 & 182.33 & 191.83 & 9.50 & 9.99 & 105.16 \\
\hline $27 X$ & 2 Jan 2008 & 1748 & 1954 & 4096.14 & 4105.64 & 191.83 & 201.33 & 9.50 & 10.03 & 105.58 \\
\hline $28 \mathrm{X}$ & $2 \operatorname{Jan} 2008$ & 2054 & 2250 & 4105.64 & 4115.14 & 201.33 & 210.83 & 9.50 & 4.04 & 42.53 \\
\hline $29 x$ & $3 \operatorname{Jan} 2008$ & 0405 & 0603 & 4115.14 & 4124.64 & 210.83 & 220.33 & 9.50 & 10.00 & 105.26 \\
\hline $30 x$ & 3 Jan 2008 & 1107 & 1317 & 4124.64 & 4134.14 & 220.33 & 229.83 & 9.50 & 9.87 & 103.89 \\
\hline $31 x$ & 3 Jan 2008 & 1412 & 1625 & 4134.14 & 4143.64 & 229.83 & 239.33 & 9.50 & 5.92 & 62.32 \\
\hline $32 X$ & 3 Jan 2008 & 1748 & 1936 & 4143.64 & 4153.14 & 239.33 & 248.83 & 9.50 & 9.00 & 94.74 \\
\hline $33 x$ & 3 Jan 2008 & 2050 & 2245 & 4153.14 & 4162.64 & 248.83 & 258.33 & 9.50 & 0.00 & 0.00 \\
\hline $34 X$ & $4 \operatorname{Jan} 2008$ & 0033 & 0301 & 4162.64 & 4172.14 & 258.33 & 267.83 & 9.50 & 8.60 & 90.53 \\
\hline $35 X$ & 4 Jan 2008 & 0458 & 0722 & 4172.14 & 4181.64 & 267.83 & 277.33 & 9.50 & 3.68 & 38.74 \\
\hline $36 X$ & 4 Jan 2008 & 1150 & 1358 & 4181.64 & 4191.14 & 277.33 & 286.83 & 9.50 & 9.83 & 103.47 \\
\hline $37 X$ & 4 Jan 2008 & 1516 & 1722 & 4191.14 & 4200.64 & 286.83 & 296.33 & 9.50 & 9.08 & 95.58 \\
\hline $38 \mathrm{X}$ & 4 Jan 2008 & 1840 & 2035 & 4200.64 & 4210.14 & 296.33 & 305.83 & 9.50 & 1.32 & 13.89 \\
\hline $39 x$ & 4 Jan 2008 & 2158 & 2337 & 4210.14 & 4219.64 & 305.83 & 315.33 & 9.50 & 9.91 & 104.32 \\
\hline $40 x$ & 5 Jan 2008 & 0108 & 0319 & 4219.64 & 4229.14 & 315.33 & 324.83 & 9.50 & 8.78 & 92.42 \\
\hline $41 x$ & 5 Jan 2008 & 0424 & 0616 & 4229.14 & 4238.64 & 324.83 & 334.33 & 9.50 & 7.15 & 75.26 \\
\hline $42 X$ & 5 Jan 2008 & 0826 & 1047 & 4238.64 & 4248.14 & 334.33 & 343.83 & 9.50 & 9.88 & 104.00 \\
\hline $43 x$ & 5 Jan 2008 & 1532 & 1751 & 4248.14 & 4257.64 & 343.83 & 353.33 & 9.50 & 8.54 & 89.89 \\
\hline $44 X$ & 5 Jan 2008 & 2012 & 2209 & 4257.64 & 4267.14 & 353.33 & 362.83 & 9.50 & 9.89 & 104.11 \\
\hline $45 X$ & 5 Jan 2008 & 2332 & 0123 & 4267.14 & 4276.64 & 362.83 & 372.33 & 9.50 & 9.89 & 104.11 \\
\hline $46 X$ & $6 \operatorname{Jan} 2008$ & 0332 & 0523 & 4276.64 & 4286.14 & 372.33 & 381.83 & 9.50 & 8.30 & 87.37 \\
\hline $47 X$ & $6 \operatorname{Jan} 2008$ & 0734 & 0935 & 4286.14 & 4295.64 & 381.83 & 391.33 & 9.50 & 9.82 & 103.37 \\
\hline $48 x$ & $6 \operatorname{Jan} 2008$ & 1104 & 1320 & 4295.64 & 4305.14 & 391.33 & 400.83 & 9.50 & 9.84 & 103.58 \\
\hline $49 x$ & $6 \operatorname{Jan} 2008$ & 1622 & 0333 & 4305.14 & 4313.75 & 400.83 & 409.44 & 8.61 & 6.04 & 70.15 \\
\hline
\end{tabular}

Note: $\mathrm{DRF}=$ drillers depth below rig floor, CSF = core depth below seafloor. 
Table T2. Coring summary, Hole C0006F. (See table note.)

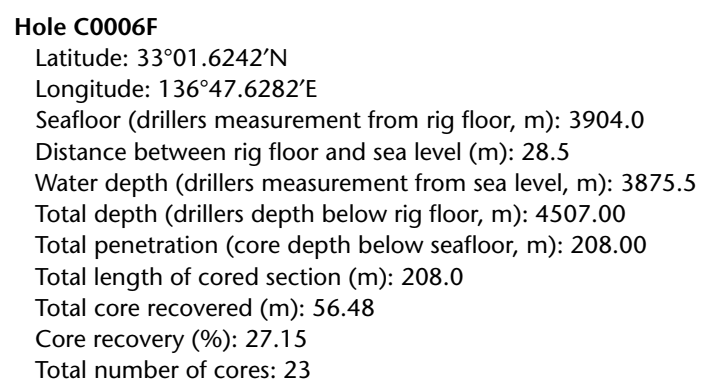

\begin{tabular}{|c|c|c|c|c|c|c|c|c|c|c|}
\hline \multirow[b]{2}{*}{ Core } & \multirow{2}{*}{$\begin{array}{c}\text { Date } \\
\text { (Jan 2008) }\end{array}$} & \multicolumn{2}{|c|}{ Local time } & \multicolumn{2}{|c|}{ Depth DRF $(m)$} & \multicolumn{2}{|c|}{ Depth CSF (m) } & \multirow{2}{*}{$\begin{array}{l}\text { Advanced } \\
\text { (m) }\end{array}$} & \multirow{2}{*}{$\begin{array}{l}\text { Recovered } \\
(\mathrm{m})\end{array}$} & \multirow{2}{*}{$\begin{array}{c}\text { Recovery } \\
(\%)\end{array}$} \\
\hline & & Shot & On deck & Top & Bottom & Top & Bottom & & & \\
\hline \multicolumn{11}{|c|}{ 316-C0006F- } \\
\hline $1 \mathrm{R}$ & 9 & 0202 & 0355 & 4299.0 & 4308.5 & 395.00 & 404.50 & 9.50 & 2.16 & 22.74 \\
\hline $2 \mathrm{R}$ & 9 & 0509 & 0712 & 4308.5 & 4318.0 & 404.50 & 414.00 & 9.50 & 2.66 & 28.00 \\
\hline $3 R$ & 9 & 0838 & 1038 & 4318.0 & 4327.5 & 414.00 & 423.50 & 9.50 & 1.91 & 20.11 \\
\hline $4 \mathrm{R}$ & 9 & 1148 & 1352 & 4327.5 & 4337.0 & 423.50 & 433.00 & 9.50 & 2.26 & 23.79 \\
\hline $5 \mathrm{R}$ & 9 & 1443 & 1649 & 4337.0 & 4342.0 & 433.00 & 438.00 & 5.00 & 1.88 & 37.60 \\
\hline $6 \mathrm{R}$ & 9 & 1828 & 2019 & 4342.0 & 4351.5 & 438.00 & 447.50 & 9.50 & 1.96 & 20.63 \\
\hline $7 \mathrm{R}$ & 9 & 2218 & 0001 & 4351.5 & 4361.0 & 447.50 & 457.00 & 9.50 & 2.49 & 26.21 \\
\hline $8 \mathrm{R}$ & 10 & 0130 & 0334 & 4361.0 & 4370.5 & 457.00 & 466.50 & 9.50 & 2.21 & 23.26 \\
\hline $9 \mathrm{R}$ & 10 & 0432 & 0620 & 4370.5 & 4380.0 & 466.50 & 476.00 & 9.50 & 2.33 & 24.53 \\
\hline $10 \mathrm{R}$ & 10 & 0721 & 0938 & 4380.0 & 4389.5 & 476.00 & 485.50 & 9.50 & 1.89 & 19.89 \\
\hline $11 \mathrm{R}$ & 10 & 1022 & 1231 & 4389.5 & 4399.0 & 485.50 & 495.00 & 9.50 & 2.50 & 26.32 \\
\hline $12 \mathrm{R}$ & 10 & 1335 & 1518 & 4399.0 & 4408.5 & 495.00 & 504.50 & 9.50 & 2.75 & 28.95 \\
\hline $13 \mathrm{R}$ & 10 & 1639 & 1816 & 4408.5 & 4418.0 & 504.50 & 514.00 & 9.50 & 3.04 & 32.00 \\
\hline $14 \mathrm{R}$ & 10 & 1931 & 2103 & 4418.0 & 4427.5 & 514.00 & 523.50 & 9.50 & 4.38 & 46.11 \\
\hline $15 \mathrm{R}$ & 10 & 2234 & 0013 & 4427.5 & 4437.0 & 523.50 & 533.00 & 9.50 & 3.48 & 36.63 \\
\hline $16 \mathrm{R}$ & 11 & 0123 & 0326 & 4437.0 & 4446.5 & 533.00 & 542.50 & 9.50 & 2.30 & 24.21 \\
\hline $17 R$ & 11 & 0441 & 0648 & 4446.5 & 4456.0 & 542.50 & 552.00 & 9.50 & 2.08 & 21.89 \\
\hline $18 \mathrm{R}$ & 11 & 0906 & 1054 & 4456.0 & 4465.5 & 552.00 & 561.50 & 9.50 & 1.99 & 20.95 \\
\hline $19 \mathrm{R}$ & 11 & 1329 & 1504 & 4465.5 & 4475.0 & 561.50 & 571.00 & 9.50 & 6.47 & 68.11 \\
\hline $20 \mathrm{R}$ & 11 & 1738 & 1924 & 4475.0 & 4484.5 & 571.00 & 580.50 & 9.50 & 2.61 & 27.47 \\
\hline $21 R$ & 11 & 2219 & 0059 & 4484.5 & 4494.0 & 580.50 & 590.00 & 9.50 & 0.10 & 1.05 \\
\hline $22 \mathrm{R}$ & 11 & 0740 & 0927 & 4494.0 & 4497.5 & 590.00 & 593.50 & 3.50 & 2.08 & 59.43 \\
\hline $23 \mathrm{R}$ & 13 & 0257 & 0735 & 4497.5 & 4507.0 & 593.50 & 603.00 & 9.50 & 0.95 & 10.00 \\
\hline
\end{tabular}

Note: $\mathrm{DRF}=$ drillers depth below rig floor, $\mathrm{CSF}=$ core depth below seafloor. 
Table T3. Summary of lithologic units, Holes C0006E and C0006F. (See table note.)

\begin{tabular}{|c|c|c|c|c|c|c|c|c|}
\hline \multirow[b]{2}{*}{ Unit } & \multicolumn{2}{|c|}{ Hole, core, section, interval $(\mathrm{cm})$} & \multicolumn{2}{|c|}{ Depth CSF (m) } & \multirow{2}{*}{$\begin{array}{l}\text { Thickness } \\
(\mathrm{m})\end{array}$} & \multirow{2}{*}{$\begin{array}{l}\text { Stratigraphic } \\
\text { age }\end{array}$} & \multirow{2}{*}{$\begin{array}{l}\text { Lithologic } \\
\text { description }\end{array}$} & \multirow{2}{*}{$\begin{array}{l}\text { Processes } \\
\text { of formation }\end{array}$} \\
\hline & Top & Bottom & Top & Bottom & & & & \\
\hline I & $\begin{array}{l}316- \\
\text { C0006E-1H-1, } 0\end{array}$ & $\begin{array}{l}316- \\
\text { C0006E-4H-3, } 20\end{array}$ & 0.00 & 27.23 & 27.2 & Pleistocene & $\begin{array}{l}\text { Nannofossil-bearing mud, } \\
\text { interbedded sand layers, } \\
\text { and a volcanic ash layer } \\
\text { near the base }\end{array}$ & $\begin{array}{l}\text { Hemipelagic settling, } \\
\text { turbidites, and a volcanic } \\
\text { ash layer }\end{array}$ \\
\hline IIA & $\mathrm{C} 0006 \mathrm{E}-4 \mathrm{H}-3,20$ & C0006E-12H-2, 10 & 27.23 & 72.06 & 44.8 & Pleistocene & $\begin{array}{l}\text { Thick to thin sands with } \\
\text { thin interbedded } \\
\text { nannofossil-bearing mud } \\
\text { layers and a volcanic ash } \\
\text { layer }\end{array}$ & $\begin{array}{l}\text { Turbidites, hemipelagic } \\
\text { settling, and a volcanic } \\
\text { ash layer }\end{array}$ \\
\hline IIB & C0006E-12H-2, 10 & C0006E-24X-1, 0 & 72.06 & 163.33 & 91.3 & Pleistocene & $\begin{array}{l}\text { Sands interbedded with } \\
\text { nannofossil-bearing mud, } \\
\text { rare volcanic ash layers }\end{array}$ & $\begin{array}{l}\text { Turbidites, hemipelagic } \\
\text { settling, and rare volcanic } \\
\text { ash layers }\end{array}$ \\
\hline IIC & C0006E-24X-1, 0 & C0006E-48X-1, 0 & 163.33 & 391.33 & 228.0 & Pleistocene & $\begin{array}{l}\text { Mud with sand/silt layers } \\
\text { and rare volcanic layers }\end{array}$ & $\begin{array}{l}\text { Hemipelagic settling, thin- } \\
\text { bedded turbidites, and } \\
\text { rare volcanic ash falls }\end{array}$ \\
\hline IID & C0006E-48X-1, 0 & C0006F-7R-CC, 33.5 & 391.33 & 449.67 & 58.3 & Pleistocene & $\begin{array}{l}\text { Mud with volcanic ash } \\
\text { layers and rare thin silt } \\
\text { layers }\end{array}$ & $\begin{array}{l}\text { Hemipelagic settling, } \\
\text { volcanic ash layers, and } \\
\text { rare thin-bedded } \\
\text { turbidites }\end{array}$ \\
\hline III & C0006F-7R-CC, 33.5 & C0006F-23R-CC, 21 & 449.67 & 603.00 & 153.3 & $\begin{array}{l}\text { Pleistocene to } \\
\text { Miocene }\end{array}$ & Mud with tuff layers & $\begin{array}{l}\text { Hemipelagic settling and } \\
\text { rare volcanic ash layers }\end{array}$ \\
\hline
\end{tabular}

Note: $\mathrm{CSF}=$ core depth below seafloor. 
Table T4. XRD data, Site C0006. (See table notes.) (Continued on next four pages.)

\begin{tabular}{|c|c|c|c|c|c|c|c|c|c|c|c|c|c|c|c|c|c|c|c|c|c|c|}
\hline \multirow[b]{3}{*}{ Unit } & \multirow[b]{3}{*}{$\begin{array}{l}\text { Hole, core, section, } \\
\text { interval }(\mathrm{cm})\end{array}$} & \multirow[b]{3}{*}{$\begin{array}{l}\text { Core } \\
\text { type }\end{array}$} & \multirow[b]{3}{*}{$\begin{array}{l}\text { Depth } \\
\text { CSF (m) }\end{array}$} & \multirow{2}{*}{\multicolumn{4}{|c|}{ Peak intensity (counts/step) }} & \multirow{2}{*}{\multicolumn{4}{|c|}{ Integrated peak area (total counts) }} & \multicolumn{11}{|c|}{ Abundance calculated from SVD normalization factor } \\
\hline & & & & & & & & & & & & \multicolumn{6}{|c|}{ Calculated abundance (wt\%) } & \multicolumn{5}{|c|}{ Normalized abundance (wt\%) } \\
\hline & & & & $\frac{\vec{\pi}}{U}$ & 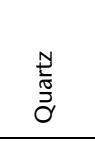 & $\begin{array}{l}\frac{0}{0} \\
\frac{\pi}{U} \\
\frac{0}{0} \\
\frac{\pi}{2} \\
\end{array}$ & $\frac{\stackrel{\mathscr{U}}{U}}{\frac{U}{U}}$ & $\frac{\pi}{U}$ & $\begin{array}{l}\frac{1}{0} \\
\text { õ } \\
\text { Oे }\end{array}$ & $\begin{array}{l}0 \\
\frac{\pi}{0} \\
\frac{\pi}{0} \\
\frac{0}{7} \\
\frac{\pi}{0} \\
\end{array}$ & $\frac{\stackrel{ \pm}{U}}{\frac{U}{N}}$ & $\frac{\vec{\sigma}}{U}$ & $\begin{array}{l}\frac{1}{0} \\
\text { oñ } \\
0\end{array}$ & $\begin{array}{l}\mathscr{\Xi} \\
\frac{\pi}{U} \\
\stackrel{\circ}{\bar{\sigma}} \\
\frac{\sigma}{2} \\
\end{array}$ & 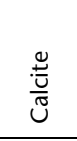 & 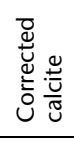 & $\begin{array}{l}\frac{0}{5} \\
\stackrel{0}{0} \overline{\frac{\pi}{2}} \\
\end{array}$ & $\frac{\widehat{\pi}}{U}$ & 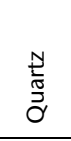 & $\begin{array}{l}\stackrel{\Xi}{0} \\
\frac{\pi}{4} \\
. \frac{0}{5} \\
\frac{\pi}{\alpha} \\
\end{array}$ & 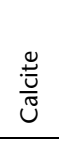 & 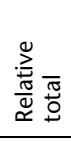 \\
\hline & $316-$ & & & & & & & & & & & & & & & & & & & & & \\
\hline \multirow[t]{27}{*}{1} & C0006E-1H-2, 0-1.5 & WR & 1.21 & 73 & 1,502 & 337 & 72 & 2,492 & 48,028 & 22,806 & 2,268 & 39.1 & 26.9 & 28.3 & -1.2 & 0.0 & 94.2 & 41.5 & 28.5 & 30.0 & 0.0 & 100 \\
\hline & C0006D-1H-2, 0-1.5 & WR & 1.21 & 50 & 1,023 & 287 & 96 & 3,013 & 45,127 & 22,477 & 3,804 & 44.2 & 25.1 & 27.8 & 0.5 & 0.5 & 97.6 & 45.3 & 25.7 & 28.5 & 0.5 & 100 \\
\hline & C0006C-1H-2, 0-1.5 & WR & 1.27 & 58 & 1,046 & 296 & 182 & 2,227 & 36,213 & 19,521 & 6,135 & 34.8 & 20.1 & 24.4 & 4.5 & 4.5 & 83.8 & 41.5 & 24.0 & 29.1 & 5.4 & 100 \\
\hline & C0006D-1H-2, 20-21.5 & WR & 1.41 & 54 & 1,333 & 346 & 119 & 2,212 & 44,939 & 24,479 & 3,496 & 37.7 & 25.0 & 30.8 & 0.7 & 0.7 & 94.2 & 40.1 & 26.6 & 32.7 & 0.7 & 100 \\
\hline & C0006E-1H-4, 69.5-71 & WR & 3.53 & 75 & 1,374 & 286 & 20 & 2,597 & 43,753 & 21,168 & 1,385 & 39.1 & 24.4 & 26.2 & -2.2 & 0.0 & 89.7 & 43.6 & 27.2 & 29.2 & 0.0 & 100 \\
\hline & C0006D-1H-5, 0-1.5 & WR & 4.04 & 68 & 1,242 & 284 & 118 & 2,754 & 38,031 & 17,717 & 5,457 & 38.6 & 21.2 & 21.7 & 3.3 & 3.3 & 84.7 & 45.5 & 25.0 & 25.6 & 3.9 & 100 \\
\hline & C0006E-1H-5, 0-1.5 & WR & 4.24 & 78 & 1,750 & 388 & 85 & 1,934 & 53,198 & 26,172 & 2,630 & 35.8 & 29.9 & 32.8 & -0.6 & 0.0 & 98.4 & 36.4 & 30.3 & 33.3 & 0.0 & 100 \\
\hline & C0006E-1H-6, 49.5-51 & WR & 4.97 & 66 & 1,192 & 230 & 130 & 2,682 & 37,509 & 15,697 & 4,398 & 36.4 & 21.0 & 18.9 & 2.0 & 2.0 & 78.3 & 46.4 & 26.8 & 24.2 & 2.6 & 100 \\
\hline & $\mathrm{C} 0006 \mathrm{C}-1 \mathrm{H}-6,0-1.5$ & WR & 5.97 & 85 & 1,475 & 260 & 72 & 2,512 & 45,498 & 20,002 & 2,423 & 37.4 & 25.5 & 24.5 & -0.8 & 0.0 & 87.4 & 42.8 & 29.2 & 28.1 & 0.0 & 100 \\
\hline & C0006E-2H-3, 0-1.5 & WR & 7.79 & 66 & 1,430 & 296 & 77 & 2,551 & 43,158 & 18,377 & 2,757 & 36.7 & 24.2 & 22.4 & -0.3 & 0.0 & 83.3 & 44.1 & 29.0 & 26.9 & 0.0 & 100 \\
\hline & C0006E-2H-4, 115.5-117 & WR & 9.18 & 58 & 1,137 & 305 & 190 & 2,491 & 39,127 & 19,912 & 7,366 & 37.6 & 21.8 & 24.7 & 5.9 & 5.9 & 89.9 & 41.8 & 24.2 & 27.5 & 6.5 & 100 \\
\hline & C0006E-2H-7, 0-1.5 & WR & 12.09 & 58 & 1,310 & 401 & 159 & 2,528 & 43,545 & 25,505 & 5,520 & 41.8 & 24.1 & 32.2 & 3.1 & 3.1 & 101.1 & 41.3 & 23.9 & 31.8 & 3.0 & 100 \\
\hline & C0006E-3H-3, 0-1.5 & WR & 17.29 & 55 & 1,692 & 376 & 63 & 2,008 & 53,637 & 25,095 & 1,879 & 35.7 & 30.1 & 31.3 & -1.6 & 0.0 & 97.1 & 36.8 & 31.0 & 32.2 & 0.0 & 100 \\
\hline & C0006E-3H-6, 55-56.5 & WR & 20.98 & 72 & 949 & 275 & 136 & 3,157 & 28,088 & 16,714 & 4,404 & 42.3 & 15.3 & 20.7 & 2.0 & 2.0 & 80.2 & 52.7 & 19.1 & 25.8 & 2.4 & 100 \\
\hline & C0006E-3H-6, 95-96.5 & WR & 21.38 & 69 & 1,255 & 250 & 250 & 2,613 & 42,754 & 17,744 & 8,129 & 37.1 & 24.0 & 21.5 & 6.7 & 6.7 & 89.3 & 41.5 & 26.9 & 24.1 & 7.5 & 100 \\
\hline & C0006E-3H-7, 0-1.5 & WR & 21.66 & 61 & 1,457 & 347 & 164 & 2,449 & 44,827 & 21,539 & 5,744 & 38.0 & 25.1 & 26.7 & 3.5 & 3.5 & 93.3 & 40.8 & 26.9 & 28.6 & 3.8 & 100 \\
\hline & C0006E-3H-7, 0-1.5 & WR & 21.66 & 69 & 1,401 & 375 & 36 & 2,962 & 49,088 & 23,772 & 1,060 & 44.3 & 27.4 & 29.4 & -3.2 & 0.0 & 101.1 & 43.9 & 27.1 & 29.1 & 0.0 & 100 \\
\hline & C0006E-4H-4, 29.5-31 & WR & 28.74 & 57 & 1,479 & 396 & 105 & 2,236 & 47,307 & 26,887 & 2,165 & 39.6 & 26.3 & 34.0 & -1.3 & 0.0 & 99.8 & 39.6 & 26.4 & 34.0 & 0.0 & 100 \\
\hline & C0006E-4H-5, 0-1.5 & WR & 29.92 & 53 & 1,521 & 485 & 64 & 2,027 & 46,871 & 33,140 & 2,412 & 42.1 & 25.8 & 42.6 & -1.0 & 0.0 & 110.5 & 38.1 & 23.4 & 38.6 & 0.0 & 100 \\
\hline & C0006E-5H-1, 126.5-128 & WR & 34.49 & 68 & 1,110 & 250 & 55 & 3,201 & 35,218 & 19,069 & 1,173 & 43.9 & 19.4 & 23.5 & -2.6 & 0.0 & 86.9 & 50.6 & 22.3 & 27.1 & 0.0 & 100 \\
\hline & C0006E-5H-3, 0-1.5 & WR & 35.84 & 54 & 1,621 & 703 & 62 & 1,657 & 51,647 & 42,159 & 1,215 & 44.7 & 28.3 & 54.9 & -2.8 & 0.0 & 127.9 & 35.0 & 22.1 & 42.9 & 0.0 & 100 \\
\hline & C0006E-5H-4, 20-21.5 & WR & 36.26 & 51 & 1,340 & 617 & 61 & 1,673 & 43,820 & 34,518 & 1,926 & 39.7 & 24.0 & 44.8 & -1.3 & 0.0 & 108.5 & 36.6 & 22.1 & 41.3 & 0.0 & 100 \\
\hline & C0006E-5H-5, 70-71.5 & WR & 38.20 & 48 & 2,142 & 851 & 37 & 1,190 & 62,199 & 46,300 & 1,192 & 42.6 & 34.4 & 60.2 & -2.9 & 0.0 & 137.2 & 31.0 & 25.1 & 43.9 & 0.0 & 100 \\
\hline & C0006E-7H-2, 115.5-117 & WR & 41.25 & 47 & 1,442 & 439 & 60 & 624 & 44,469 & 32,271 & 2,016 & 27.7 & 24.7 & 42.0 & -0.4 & 0.0 & 94.3 & 29.3 & 26.2 & 44.5 & 0.0 & 100 \\
\hline & C0006E-7H-4, 0-1.5 & WR & 42.92 & 43 & 1,988 & 866 & 45 & 813 & 60,897 & 52,569 & 1,392 & 43.5 & 33.4 & 69.0 & -2.6 & 0.0 & 145.9 & 29.8 & 22.9 & 47.3 & 0.0 & 100 \\
\hline & C0006E-7H-4, 20.5-22 & WR & 43.12 & 61 & 2,136 & 581 & 56 & 733 & 60,418 & 37,724 & 1,537 & 31.9 & 33.8 & 48.6 & -1.8 & 0.0 & 114.4 & 27.9 & 29.5 & 42.5 & 0.0 & 100 \\
\hline & C0006E-8H-1, 55-56.5 & WR & 48.74 & 65 & 1,300 & 355 & 102 & 2,675 & 41,841 & 21,350 & 3,214 & 40.2 & 23.3 & 26.5 & 0.2 & 0.2 & 90.1 & 44.6 & 25.8 & 29.4 & 0.2 & 100 \\
\hline \multirow[t]{18}{*}{ IIA } & C0006E-8H-2, 86.5-88 & WR & 50.45 & 57 & 2,354 & 976 & 41 & 721 & 66,420 & 51,194 & 1,423 & 41.3 & 36.7 & 66.8 & -2.6 & 0.0 & 144.9 & 28.5 & 25.4 & 46.1 & 0.0 & 100 \\
\hline & C0006E-8H-4, 0-1.5 & WR & 51.79 & 52 & 1,228 & 266 & 136 & 2,827 & 38,415 & 20,707 & 4,227 & 41.4 & 21.3 & 25.7 & 1.5 & 1.5 & 89.9 & 46.1 & 23.6 & 28.6 & 1.7 & 100 \\
\hline & C0006E-9H-2, 93-94.5 & WR & 60.04 & 51 & 1,133 & 320 & 107 & 2,722 & 35,124 & 21,055 & 3,640 & 40.8 & 19.3 & 26.4 & 0.9 & 0.9 & 87.4 & 46.6 & 22.1 & 30.2 & 1.0 & 100 \\
\hline & C0006E-9H-5, 0-1.5 & WR & 62.41 & 53 & 1,984 & 484 & 42 & 926 & 61,022 & 31,881 & 1,511 & 29.6 & 34.4 & 40.5 & -1.8 & 0.0 & 104.5 & 28.3 & 32.9 & 38.8 & 0.0 & 100 \\
\hline & C0006E-10H-8, 0-1.5 & WR & 64.51 & 58 & 1,741 & 550 & 57 & 1,137 & 50,687 & 30,665 & 1,550 & 31.2 & 28.3 & 39.3 & -1.5 & 0.0 & 98.9 & 31.6 & 28.6 & 39.8 & 0.0 & 100 \\
\hline & C0006E-11H-1, 79-81 & WR & 65.46 & 66 & 1,237 & 287 & 38 & 3,099 & 38,716 & 20,212 & 1,441 & 43.6 & 21.4 & 25.0 & -2.3 & 0.0 & 90.0 & 48.5 & 23.8 & 27.8 & 0.0 & 100 \\
\hline & C0006E-11H-4, 0-1.5 & WR & 67.70 & 46 & 2,066 & 447 & 52 & 1,452 & 60,935 & 30,851 & 1,522 & 34.0 & 34.3 & 39.0 & -2.1 & 0.0 & 107.3 & 31.7 & 31.9 & 36.3 & 0.0 & 100 \\
\hline & C0006E-12H-6, 0-1.5 & WR & 76.31 & 52 & 1,487 & 432 & 67 & 2,118 & 46,132 & 29,603 & 2,232 & 40.4 & 25.5 & 37.8 & -1.1 & 0.0 & 103.7 & 39.0 & 24.6 & 36.4 & 0.0 & 100 \\
\hline & C0006E-15X-4, 0-1.5 & WR & 81.76 & 59 & 1,608 & 288 & 80 & 2,795 & 47,542 & 21,115 & 2,397 & 40.9 & 26.6 & 25.9 & -1.2 & 0.0 & 93.4 & 43.8 & 28.5 & 27.7 & 0.0 & 100 \\
\hline & C0006E-16X-1, 96.5-98 & WR & 89.80 & 76 & 1,227 & 528 & 54 & 2,925 & 43,853 & 26,852 & 1,929 & 46.5 & 24.2 & 33.9 & -2.0 & 0.0 & 104.6 & 44.5 & 23.1 & 32.4 & 0.0 & 100 \\
\hline & C0006E-16X-2, 0-1.5 & WR & 90.11 & 59 & 1,592 & 446 & 63 & 2,250 & 48,692 & 28,041 & 2,172 & 40.5 & 27.1 & 35.5 & -1.3 & 0.0 & 103.0 & 39.3 & 26.3 & 34.4 & 0.0 & 100 \\
\hline & C0006E-17X-1, 115.5-117 & WR & 99.49 & 61 & 1,470 & 601 & 55 & 1,962 & 49,849 & 35,439 & 1,823 & 42.9 & 27.5 & 45.7 & -1.9 & 0.0 & 116.1 & 37.0 & 23.7 & 39.3 & 0.0 & 100 \\
\hline & C0006E-17X-3, 0-1.5 & WR & 100.30 & 61 & 1,584 & 446 & 47 & 1,880 & 49,918 & 26,851 & 1,436 & 35.9 & 27.9 & 33.9 & -2.0 & 0.0 & 97.7 & 36.7 & 28.6 & 34.7 & 0.0 & 100 \\
\hline & C0006E-17X-5, 27.5-29 & WR & 101.45 & 61 & 1,279 & 482 & 107 & 1,589 & 42,371 & 36,680 & 4,360 & 40.6 & 23.1 & 47.8 & 1.9 & 1.9 & 113.4 & 35.8 & 20.4 & 42.2 & 1.7 & 100 \\
\hline & C0006E-19X-3, 113.5-115 & WR & 118.40 & 63 & 1,211 & 468 & 67 & 1,738 & 41,678 & 28,805 & 1,905 & 36.3 & 23.0 & 37.0 & -1.1 & 0.0 & 96.3 & 37.7 & 23.9 & 38.4 & 0.0 & 100 \\
\hline & C0006E-19X-4, 95.5-97 & WR & 119.62 & 59 & 1,174 & 332 & 56 & 2,286 & 40,391 & 24,675 & 1,281 & 38.7 & 22.3 & 31.3 & -2.2 & 0.0 & 92.3 & 42.0 & 24.2 & 33.9 & 0.0 & 100 \\
\hline & C0006E-19X-5, 0-1.5 & WR & 119.76 & 52 & 1,040 & 304 & 64 & 2,820 & 37,665 & 20,503 & 1,995 & 41.1 & 20.8 & 25.5 & -1.4 & 0.0 & 87.5 & 47.0 & 23.8 & 29.2 & 0.0 & 100 \\
\hline & C0006E-19X-6, 39-40.5 & WR & 120.47 & 61 & 1,054 & 260 & 138 & 2,867 & 34,359 & 18,620 & 4,727 & 40.5 & 19.0 & 23.1 & 2.3 & 2.3 & 84.8 & 47.7 & 22.3 & 27.2 & 2.7 & 100 \\
\hline
\end{tabular}




\begin{tabular}{|c|c|c|c|c|c|c|c|c|c|c|c|c|c|c|c|c|c|c|c|c|c|c|}
\hline \multirow[b]{3}{*}{ Unit } & \multirow[b]{3}{*}{$\begin{array}{l}\text { Hole, core, section, } \\
\text { interval }(\mathrm{cm})\end{array}$} & \multirow[b]{3}{*}{$\begin{array}{l}\text { Core } \\
\text { type }\end{array}$} & \multirow[b]{3}{*}{$\begin{array}{l}\text { Depth } \\
\operatorname{CSF}(m)\end{array}$} & \multirow{2}{*}{\multicolumn{4}{|c|}{ Peak intensity (counts/step) }} & \multirow{2}{*}{\multicolumn{4}{|c|}{ Integrated peak area (total counts) }} & \multicolumn{11}{|c|}{ Abundance calculated from SVD normalization factor } \\
\hline & & & & & & & & & & & & \multicolumn{6}{|c|}{ Calculated abundance (wt\%) } & \multicolumn{5}{|c|}{ Normalized abundance (wt\%) } \\
\hline & & & & $\frac{\widehat{\pi}}{U}$ & $\begin{array}{l}\frac{1}{0} \\
\frac{0}{20} \\
0\end{array}$ & 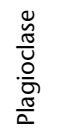 & $\frac{\stackrel{ \pm}{U}}{\frac{\pi}{\sigma}}$ & $\frac{\vec{\pi}}{U}$ & 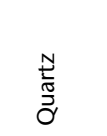 & 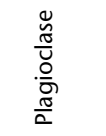 & 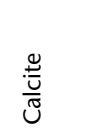 & $\frac{\bar{\theta}}{U}$ & 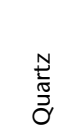 & 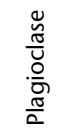 & 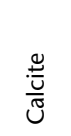 & 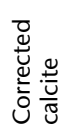 & 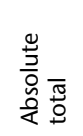 & $\frac{\pi}{U}$ & 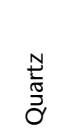 & 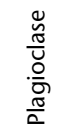 & $\frac{\stackrel{0}{U}}{\frac{U}{U}}$ & 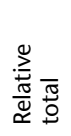 \\
\hline & $0006 \mathrm{E}-20 \mathrm{X}-1,38.5-40$ & WR & 125.72 & 44 & 1,316 & 590 & 73 & 1,084 & 45,915 & 41,393 & 2,284 & 38.8 & 25.1 & 54.3 & -0.7 & 0.0 & 118.1 & 32.8 & 21.2 & 45.9 & 0.0 & 100 \\
\hline & C0006E-20X-1, 118.5-120 & WR & 126.52 & 69 & 1,159 & 327 & 69 & 1,942 & 37,580 & 30,871 & 1,616 & 40.0 & 20.5 & 40.0 & -1.6 & 0.0 & 100.4 & 39.8 & 20.4 & 39.8 & 0.0 & 100 \\
\hline & C0006E-20X-2, 121.5-123 & WR & 127.96 & 95 & 1,049 & 239 & 76 & 3,165 & 39,026 & 15,951 & 2,222 & 41.2 & 21.8 & 19.1 & -1.2 & 0.0 & 82.0 & 50.2 & 26.5 & 23.3 & 0.0 & 100 \\
\hline & C0006E-20X-3, 0-1.5 & WR & 128.16 & 68 & 1,244 & 256 & 63 & 3,270 & 41,357 & 17,877 & 1,943 & 43.5 & 23.0 & 21.6 & -1.8 & 0.0 & 88.1 & 49.4 & 26.1 & 24.5 & 0.0 & 100 \\
\hline & C0006E-20X-5, 33.5-35 & WR & 131.34 & 57 & 772 & 256 & 78 & 3,401 & 35,836 & 19,744 & 3,652 & 46.5 & 19.7 & 24.4 & 0.4 & 0.4 & 91.0 & 51.1 & 21.6 & 26.8 & 0.5 & 100 \\
\hline & C0006E-20X-5, 108-109.5 & WR & 132.09 & 50 & 1,231 & 399 & 99 & 2,162 & 40,527 & 26,678 & 2,898 & 39.0 & 22.3 & 34.0 & 0.0 & 0.0 & 95.4 & 40.9 & 23.4 & 35.7 & 0.0 & 100 \\
\hline & C0006E-20X-7, 0-1.5 & WR & 132.85 & 52 & 1,319 & 508 & 73 & 1,678 & 40,447 & 32,339 & 2,636 & 38.3 & 22.1 & 41.9 & -0.2 & 0.0 & 102.4 & 37.4 & 21.6 & 40.9 & 0.0 & 100 \\
\hline & C0006E-21X-2 94-96 & W & 137.22 & 60 & 1,584 & 398 & 76 & 1,816 & 47,423 & 26,752 & 2,318 & 35.3 & 26.4 & 33.9 & -0.7 & 0.0 & 95.7 & 36.9 & 27.7 & 35.4 & 0.0 & 100 \\
\hline & C0006E-21X-3, 0-1.5 & WR & 137.38 & 70 & 1,091 & 370 & 71 & 2,084 & 34,378 & 25,499 & 2,394 & 37.7 & 18.8 & 32.7 & -0.4 & 0.0 & 89.2 & 42.2 & 21.1 & 36.7 & 0.0 & 100 \\
\hline & C0006E-21X-4, 3-5 & w & 137.73 & 89 & 994 & 217 & 78 & 3,304 & 34,239 & 15,301 & 2,168 & 42.3 & 19.0 & 18.4 & -1.2 & 0.0 & 79.7 & 53.1 & 23.8 & 23.1 & 0.0 & 100 \\
\hline \multirow[t]{12}{*}{ IIB } & C0006E-22X-2, 33-34.5 & WR & 146.07 & 59 & 1,204 & 294 & 82 & 2,798 & 41,189 & 19,435 & 1,908 & 40.0 & 22.9 & 23.9 & -1.6 & 0.0 & 86.8 & 46.1 & 26.4 & 27.5 & 0.0 & 100 \\
\hline & C0006E-22X-3, 0-1.5 & WR & 146.83 & 53 & 1,485 & 360 & 55 & 1,884 & 46,673 & 25,144 & 1,815 & 34.8 & 26.1 & 31.7 & -1.4 & 0.0 & 92.6 & 37.6 & 28.1 & 34.2 & 0.0 & 100 \\
\hline & C0006E-22X-4, 3 & WR & 147 & 64 & 1,173 & 211 & 78 & 3,143 & 38,102 & 15,450 & 2,725 & 40.7 & 21.2 & 18.5 & -0.5 & 0.0 & 80.4 & 50.6 & 26.4 & 23.0 & 0.0 & 100 \\
\hline & C0006E-22X-4, 115-116.5 & WR & 148.33 & 61 & 1,534 & 473 & 51 & 2,183 & 46,008 & 34,087 & 1,461 & 44.3 & 25.2 & 43.9 & -2.4 & 0.0 & 113.5 & 39.0 & 22.2 & 38.7 & 0.0 & 100 \\
\hline & C0006E-22X-6, 20-21.5 & WR & 150.20 & 58 & 1,665 & 409 & 76 & 2,191 & 48,797 & 27,773 & 2,358 & 39.7 & 27.2 & 35.1 & -1.1 & 0.0 & 102.0 & 38.9 & 26.6 & 34.4 & 0.0 & 100 \\
\hline & C0006E-22X-6, 66-67.5 & WR & 150.66 & 56 & 1,729 & 581 & 52 & 1,287 & 56,793 & 38,329 & 1,678 & 38.0 & 31.5 & 49.5 & -1.9 & 0.0 & 119.1 & 31.9 & 26.5 & 41.6 & 0.0 & 100 \\
\hline & C0006E-23X-1, 65-66.5 & WR & 154.48 & 58 & 1,043 & 226 & 90 & 3,453 & 37,956 & 16,166 & 3,154 & 44.3 & 21.1 & 19.4 & -0.2 & 0.0 & 84.7 & 52.3 & 24.9 & 22.8 & 0.0 & 100 \\
\hline & C0006E-23X-1, 101-102.5 & WR & 154.84 & 77 & 1,510 & 413 & 71 & 2,469 & 46,027 & 26,194 & 2,185 & 41.4 & 25.5 & 33.0 & -1.3 & 0.0 & 100.0 & 41.4 & 25.6 & 33.0 & 0.0 & 100 \\
\hline & C0006E-23X-3, 26-27.5 & WR & 15 & 58 & 1,544 & 598 & 88 & 2,021 & 51,086 & 39,205 & 2,461 & 46.2 & 28.0 & 50.7 & -1.3 & 0.0 & 125.0 & 37.0 & 22.4 & 40.6 & 0.0 & 100 \\
\hline & C0006E-23X-3, 67-68.5 & WR & 157.32 & 77 & 1,201 & 257 & 59 & 3,309 & 40,959 & 16,292 & 1,506 & 42.7 & 22.9 & 19.4 & -2.3 & 0.0 & 85.0 & 50.3 & 26.9 & 22.9 & 0.0 & 100 \\
\hline & C0006E-23X-4, 0-1.5 & WR & 157.74 & 67 & 1,036 & 221 & 69 & 3,583 & 34,894 & 14,347 & 2,357 & 44.4 & 19.3 & 17.0 & -1.2 & 0.0 & 80.7 & 55.0 & 24.0 & 21.0 & 0.0 & 100 \\
\hline & C0006E-2 & WR & & 57 & 1,461 & 284 & 69 & 2,680 & 43,997 & 22,721 & 2, & 41.1 & 24.5 & 28.3 & -1.1 & 0.0 & 93.8 & 43.8 & 26.1 & 30.1 & 0.0 & 100 \\
\hline \multirow[t]{24}{*}{ IIC } & C0006E-25X-4, 124-125 & w & 178.29 & 67 & 1,465 & 508 & 69 & 1,884 & 47,413 & 31,056 & 2,491 & 39.1 & 26.2 & 39.8 & -0.7 & 0.0 & 105.1 & 37.2 & 25.0 & 37.8 & 0.0 & 100 \\
\hline & C0006E-25X-5, 82-83 & W & 179.28 & 64 & 1,125 & 258 & 91 & 3,337 & 37,775 & 18,507 & 2,732 & 44.8 & 20.9 & 22.6 & -0.7 & 0.0 & 88.3 & 50.8 & 23.7 & 25.6 & 0.0 & 100 \\
\hline & & AR & & 71 & 1,336 & 501 & 81 & 65 & & & & 46.0 & 24.4 & 36.0 & -1.7 & 0.0 & 106.4 & 3.2 & 23.0 & 33.8 & 0.0 & 100 \\
\hline & C0006E-25X-7, 0-1.5 & WR & 180 & 51 & 1,852 & 408 & 60 & 1,903 & 56,573 & 29,789 & 1,263 & 37.9 & 31.7 & 37.6 & -2.6 & 0.0 & 107.2 & 35.4 & 29.6 & 35.1 & 0.0 & 100 \\
\hline & C0006E-26X-1, 147.5- & WR & 183.81 & 64 & 1,262 & 309 & 64 & 2,912 & 39,421 & 21,342 & 1,897 & 42.6 & 21.8 & 26.5 & -1.7 & 0.0 & 90.9 & 46.8 & 24.0 & 29.2 & 0.0 & 100 \\
\hline & C0006E-26X-2, 108-109.5 & W & & 58 & 1,261 & 463 & 28 & 1,989 & 44,429 & & & 41.0 & 24.4 & 41.3 & -1.8 & 0.0 & 106.8 & 38.4 & 22.9 & 38.7 & 0.0 & 100 \\
\hline & C0006E-26X-2, 118.5-120 & W & 18 & 73 & 1,009 & 21 & 79 & 3,651 & 37,061 & 15,656 & 2,531 & 45.9 & 20.5 & 18.6 & -1.1 & 0.0 & 85.1 & 53.9 & 24.1 & 21.9 & 0.0 & 100 \\
\hline & C0006E-26X-4, 0-1.5 & WR & 186.65 & 95 & 989 & 208 & 72 & 3,276 & 32,253 & 14,755 & 2,658 & 41.7 & 17.8 & 17.7 & -0.5 & 0.0 & 77.3 & 54.0 & 23.0 & 23.0 & 0.0 & 100 \\
\hline & C0006E-26X-8, 94.5-9 & WR & & 49 & 1,292 & 406 & 75 & 1,824 & 40,751 & 25,710 & & 35.0 & 22.6 & 32.8 & 0.0 & 0.0 & 90.4 & 38.7 & 25.0 & 36.3 & 0.1 & 100 \\
\hline & 61.5 & WR & & 62 & 1,168 & 37 & 89 & 28 & 39,753 & 19,367 & 2,9 & 44.3 & 22.0 & 23.7 & -0.4 & 0.0 & 90.0 & 49.2 & 24.5 & 26.3 & 0.0 & 100 \\
\hline & C0006E-27X-3, 113-115 & W & 195.79 & 66 & 1,092 & 286 & 71 & 3,589 & 38,491 & 19,598 & 2,337 & 48.1 & 21.2 & 24.0 & -1.5 & 0.0 & 93.3 & 51.5 & 22.8 & 25.7 & 0.0 & 100 \\
\hline & - & WR & & 53 & 1,498 & 422 & 57 & 1,689 & 49,804 & & & 35.1 & 27.8 & 36.1 & -1.6 & 0.0 & 99.0 & 35.5 & 28.1 & 36.5 & 0.0 & 100 \\
\hline & C0006E-27X-7, 118-120 & w & 200.10 & 44 & 1,406 & 48 & 49 & 1,691 & 48,215 & 33,551 & 1,909 & 39.0 & 26.6 & 43.2 & -1.5 & 0.0 & 108.8 & 35.8 & 24.5 & 39.7 & 0.0 & 100 \\
\hline & C0006E-27X-8, 30-31.5 & WR & 200.62 & 56 & 1,902 & 427 & 60 & 1,628 & 57,712 & 32,797 & 2,024 & 37.3 & 32.3 & 41.8 & -1.5 & 0.0 & 111.4 & 33.5 & 29.0 & 37.5 & 0.0 & 100 \\
\hline & C0006E-28X-1, 3 & WR & 201.64 & 65 & 1,077 & 266 & 70 & 3,112 & 37,161 & 18,919 & 2,787 & 42.9 & 20.5 & 23.3 & -0.5 & 0.0 & 86.7 & 49.5 & 23.7 & 26.8 & 0.0 & 100 \\
\hline & C0006E-28X-1, 75-77 & w & 202.0 & 0 & 1,683 & 411 & 59 & 1,877 & 50,779 & 32,349 & 1,83 & 39.8 & 28.2 & 41.4 & -1.7 & 0.0 & 109.4 & 36.4 & 25.8 & 37.9 & 0.0 & 100 \\
\hline & C0006E-28X-1, 91-92.5 & WR & 202.24 & 59 & 1,462 & 370 & 57 & 2,199 & 49,846 & 27,936 & 1,876 & 39.8 & 27.8 & 35.3 & -1.7 & 0.0 & 102.9 & 38.7 & 27.0 & 34.3 & 0.0 & 100 \\
\hline & C0006E-28X-2, 97-99 & W & 203.71 & 70 & 1,076 & 243 & 76 & 3,882 & 36,064 & 16,314 & 2,262 & 48.7 & 19.9 & 19.5 & -1.6 & 0.0 & 88.1 & 55.3 & 22.6 & 22.2 & 0.0 & 100 \\
\hline & & WF & & 5 & & 355 & 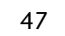 & & & & & 46.8 & 28.6 & 32.9 & -2.9 & 0.0 & 108.3 & 43.2 & 26.4 & 30.4 & 0.0 & 100 \\
\hline & C0006E-28X-4, 75-76.5 & WR & 204.92 & 58 & 1,794 & 355 & 71 & 2,755 & 53,304 & 24,961 & 1,703 & 43.0 & 29.8 & 30.9 & -2.4 & 0.0 & 103.7 & 41.4 & 28.8 & 29.8 & 0.0 & 100 \\
\hline & C0006E-29X-2, 84.5-86 & WR & 213.11 & 84 & 1,209 & 250 & 89 & 3,664 & 40,739 & 16,894 & 2,083 & 46.7 & 22.6 & 20.2 & -1.9 & 0.0 & 89.5 & 52.2 & 25.3 & 22.5 & 0.0 & 100 \\
\hline & 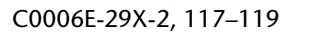 & w & & 44 & 1,438 & 585 & 60 & 1,810 & 50,512 & 34,184 & 2,094 & 40.5 & 27.9 & 44.0 & -1.4 & 0.0 & 112.4 & 36.0 & 24.9 & 39.1 & 0.0 & 100 \\
\hline & C0006E-29X-2, $126-128$ & W & 213.52 & 66 & 1,146 & 269 & 51 & 3,477 & 39,054 & 16,894 & 1,504 & 44.9 & 21.7 & 20.3 & -2.4 & 0.0 & 86.9 & 51.7 & 25.0 & 23.4 & 0.0 & 100 \\
\hline & C0006E-29X-7, 0-1.5 & WR & 219.04 & 87 & 1,218 & 252 & 74 & 3,503 & 39,428 & 17,905 & 2,352 & 45.9 & 21.9 & 21.7 & -1.4 & 0.0 & 89.5 & 51.4 & 24.4 & 24.2 & 0.0 & 100 \\
\hline
\end{tabular}




\begin{tabular}{|c|c|c|c|c|c|c|c|c|c|c|c|c|c|c|c|c|c|c|c|c|c|c|}
\hline \multirow[b]{3}{*}{ Unit } & \multirow[b]{3}{*}{$\begin{array}{l}\text { Hole, core, section, } \\
\text { interval }(\mathrm{cm})\end{array}$} & \multirow[b]{3}{*}{$\begin{array}{l}\text { Core } \\
\text { type }\end{array}$} & \multirow[b]{3}{*}{$\begin{array}{l}\text { Depth } \\
\operatorname{CSF}(m)\end{array}$} & \multirow{2}{*}{\multicolumn{4}{|c|}{ Peak intensity (counts/step) }} & \multirow{2}{*}{\multicolumn{4}{|c|}{ Integrated peak area (total counts) }} & \multicolumn{11}{|c|}{ Abundance calculated from SVD normalization factor } \\
\hline & & & & & & & & & & & & \multicolumn{6}{|c|}{ Calculated abundance (wt\%) } & \multicolumn{5}{|c|}{ Normalized abundance (wt\%) } \\
\hline & & & & $\frac{\widehat{\sigma}}{U}$ & $\begin{array}{l}\frac{1}{0} \\
\frac{0}{20} \\
0\end{array}$ & 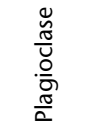 & $\frac{\stackrel{ \pm}{U}}{\widetilde{N}}$ & $\frac{\vec{\pi}}{U}$ & $\begin{array}{l}\frac{1}{0} \\
\frac{0}{0} \\
\frac{a}{2}\end{array}$ & 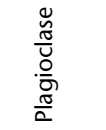 & 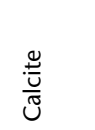 & $\frac{\vec{\sigma}}{U}$ & $\begin{array}{l}\frac{N}{0} \\
\frac{\pi}{2} \\
0\end{array}$ & 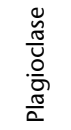 & 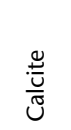 & 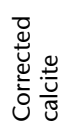 & 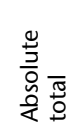 & $\frac{\vec{\pi}}{U}$ & 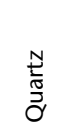 & 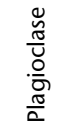 & 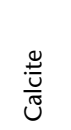 & 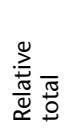 \\
\hline & C0006E-30X-1, 10-11 & W & 220.43 & 58 & 1,385 & 586 & 51 & 1,587 & 44,060 & 39,704 & 1,839 & 42.6 & 24.0 & 51.9 & -1.6 & 0.0 & 118.5 & 36.0 & 20.2 & 43.8 & 0.0 & 100 \\
\hline & C0006E-30X-1, 107-108.5 & WR & 221.40 & 80 & 1,175 & 313 & 69 & 3,228 & 40,554 & 21,895 & 1,552 & 46.0 & 22.4 & 27.2 & -2.4 & 0.0 & 95.6 & 48.2 & 23.4 & 28.4 & 0.0 & 100 \\
\hline & C0006E-30X-2, 46-47 & W & 222.20 & 89 & 528 & 123 & 200 & 3,029 & 17,910 & 8,619 & 8,288 & 35.8 & 9.7 & 10.1 & 7.7 & 7.7 & 63.2 & 56.5 & 15.3 & 15.9 & 12.2 & 100 \\
\hline & C0006E-30X-3, 0-1.5 & WR & 223.16 & 85 & 1,154 & 252 & 78 & 4,053 & 37,885 & 15,384 & 1,674 & 49.6 & 21.0 & 18.1 & -2.5 & 0.0 & 88.7 & 55.9 & 23.7 & 20.4 & 0.0 & 100 \\
\hline & C0006E-30X-8, 80.5-82 & WR & 229.63 & 77 & 1,157 & 248 & 127 & 4,154 & 37,942 & 17,113 & 4,381 & 52.0 & 20.9 & 20.4 & 0.9 & 0.9 & 94.2 & 55.2 & 22.2 & 21.7 & 0.9 & 100 \\
\hline & C0006E-31X-1, 122-124 & W & 231.05 & 39 & 1,585 & 1,311 & 73 & 575 & 45,163 & 54,444 & 2,615 & 43.3 & 24.1 & 72.4 & -0.4 & 0.0 & 139.8 & 31.0 & 17.3 & 51.8 & 0.0 & 100 \\
\hline & C0006E-31X-3, 0-1.5 & WR & 232.32 & 52 & 1,496 & 711 & 64 & 751 & 47,107 & 40,802 & 1,739 & 35.0 & 25.8 & 53.5 & -1.2 & 0.0 & 114.3 & 30.6 & 22.6 & 46.8 & 0.0 & 100 \\
\hline & C0006E-31X-4, 65-66.5 & WR & 233.34 & 60 & 1,080 & 364 & 83 & 2,116 & 37,307 & 22,932 & 2,484 & 36.0 & 20.6 & 29.1 & -0.3 & 0.0 & 85.7 & 42.0 & 24.1 & 33.9 & 0.0 & 100 \\
\hline & C0006E-31X-5, 113-115 & w & 235.24 & 64 & 682 & 211 & 163 & 3,146 & 23,408 & 15,218 & 5,695 & 41.3 & 12.6 & 18.8 & 3.8 & 3.8 & 76.6 & 53.9 & 16.5 & 24.6 & 5.0 & 100 \\
\hline & C0006E-32X-4, 0-1.5 & WR & 243 & 82 & 937 & 238 & 96 & 2,951 & 32,818 & 16,511 & 3,237 & 39.8 & 18.1 & 20.2 & 0.4 & 0.4 & 78.6 & 50.7 & 23.1 & 25.7 & 0.6 & 100 \\
\hline & C0006E-32X-5, 23-24.5 & WR & 243.82 & 80 & 1,085 & 237 & 66 & 3,467 & 38,351 & 17,230 & 1,856 & 45.1 & 21.3 & 20.8 & -1.9 & 0.0 & 87.2 & 51.8 & 24.4 & 23.9 & 0.0 & 100 \\
\hline & C0006E-32X-5, 91.5-93 & WR & 244.51 & 57 & 1,112 & 405 & 52 & 2,283 & 39,770 & 27,710 & 1,626 & 41.0 & 21.8 & 35.4 & -1.8 & 0.0 & 98.2 & 41.7 & 22.2 & 36.1 & 0.0 & 100 \\
\hline & C0006E-32X-6, $18.5-20$ & WR & 245 & 58 & 1,026 & 310 & 101 & 2,802 & 39,872 & 21,771 & 2,757 & 41.8 & 22.1 & 27.1 & -0.5 & 0.0 & 91.0 & 45.9 & 24.2 & 29.8 & 0.0 & 100 \\
\hline & C0006E-32X-7, 55-57 & W & 246.97 & 61 & 788 & 461 & 150 & 2,395 & 26,624 & 25,769 & 5,417 & 41.4 & 14.2 & 33.4 & 3.6 & 3.6 & 92.5 & 44.8 & 15.3 & 36.1 & 3.8 & 100 \\
\hline & C0006E-32X-8, 27-29 & W & 247.60 & 10 & 1,089 & 639 & 92 & 1,183 & 35,005 & 34,565 & 3,685 & 35.4 & 18.9 & 45.4 & 1.6 & 1.6 & 101.3 & 34.9 & 18.7 & 44.8 & 1.6 & 100 \\
\hline & C0006E-34X-1, 0-5 & W & 258.33 & 39 & 106 & 52 & 46 & 1,584 & 3,632 & 2,785 & 1,828 & 17.6 & 1.8 & 3.2 & 1.0 & 1.0 & 23.6 & 74.7 & 7.5 & 13.5 & 4.3 & 100 \\
\hline & C0006E-34X-2, 115-117 & w & 260.89 & 85 & 1,058 & 275 & 70 & 3,426 & 38,634 & 19,995 & 2,782 & 46.8 & 21.3 & 24.6 & -0.8 & 0.0 & 92.7 & 50.5 & 23.0 & 26.5 & 0.0 & 100 \\
\hline & C0006E-34X-3, 94-95.5 & WR & 262.09 & 53 & 1,150 & 286 & 90 & 2,957 & 36,732 & 18,434 & 2,395 & 41.0 & 20.3 & 22.7 & -0.9 & 0.0 & 84.1 & 48.8 & 24.2 & 27.0 & 0.0 & 100 \\
\hline & C0006E-34X-4, 44-45.5 & WR & 263.01 & 79 & 1,195 & 361 & 96 & 3,352 & 40,832 & 23,098 & 2,714 & 48.2 & 22.5 & 28.8 & -1.0 & 0.0 & 99.4 & 48.5 & 22.6 & 28.9 & 0.0 & 100 \\
\hline & C0006E-34X-5, 0-1.5 & WR & 263.62 & 58 & 1,284 & 278 & 63 & 3,362 & 40,543 & 18,880 & 1,952 & 45.2 & 22.5 & 23.0 & -1.9 & 0.0 & 90.7 & 49.8 & 24.8 & 25.4 & 0.0 & 100 \\
\hline & C0006E-35X-2, 0-1.5 & WR & 268.69 & 72 & 954 & 443 & 81 & 1,624 & 33,409 & 32,992 & 3,004 & 38.6 & 18.0 & 43.2 & 0.5 & 0.5 & 100.3 & 38.5 & 17.9 & 43.1 & 0.5 & 100 \\
\hline & C0006E-35X-3, 51-52 & W & 269.57 & 51 & 1,647 & 485 & 60 & 1,485 & 50,511 & 36,493 & 1,768 & 38.9 & 27.9 & 47.2 & -1.7 & 0.0 & 114.1 & 4.1 & 24.5 & 41.4 & 0.0 & 100 \\
\hline & C0006E-35X-3, 59-60 & W & 269.65 & 63 & 1,138 & 318 & 86 & 2,695 & 41,605 & 22,360 & 2,279 & 41.1 & 23.1 & 27.9 & -1.1 & 0.0 & 92.1 & 44.6 & 25.1 & 30.3 & 0.0 & 100 \\
\hline & C0006E-35X-3, 118-119.5 & WR & 270.24 & 65 & 1,580 & 368 & 82 & 2,900 & 47,647 & 24,798 & 2,838 & 44.6 & 26.5 & 30.9 & -0.8 & 0.0 & 102.0 & 43.7 & 26.0 & 30.3 & 0.0 & 100 \\
\hline & $\mathrm{COO}$ & WR & & 59 & 1,162 & 384 & 83 & 2,798 & & & & 44.7 & 22.3 & 32.6 & 0.2 & 0.2 & 99.8 & 4.8 & 22.3 & 32.7 & 0.2 & 100 \\
\hline & C0006E-36X-1, 100-101.5 & WR & 278.33 & 81 & 1,349 & 258 & 1 & 3,868 & 40,495 & 14,103 & 1,661 & 46.7 & 22.6 & 16.3 & -2.5 & 0.0 & 85.6 & 54.6 & 26.4 & 19.0 & 0.0 & 100 \\
\hline & C0006E-36X-1, 125-127 & w & 278.58 & 57 & 1,069 & 276 & 72 & 2,934 & 38,242 & 17,862 & 2,337 & 40.3 & 21.3 & 21.8 & -0.9 & 0.0 & 83.4 & 48.4 & 25.5 & 26.2 & 0.0 & 100 \\
\hline & C0006E-36X-4, 0-1.5 & WR & 28 & 74 & 1,064 & 270 & 88 & 3,426 & 37,694 & 18,056 & & 45.4 & 20.8 & 22.0 & -0.6 & 0.0 & 88.2 & 51.5 & 23.6 & 24.9 & 0.0 & 100 \\
\hline & C0006E-36X-6, 69-71 & W & 283.65 & 46 & 1,899 & 543 & 81 & 1,638 & 56,562 & 34,538 & 1,722 & 38.8 & 31.5 & 44.2 & -2.0 & 0.0 & 114.5 & 33.9 & 27.5 & 38.6 & 0.0 & 100 \\
\hline & C0006E-37X-2, 78.5-80 & WR & 289.03 & 67 & 1,015 & 254 & 103 & 3,281 & 35,846 & 17,548 & 4,087 & 43.7 & 19.8 & 21.4 & 1.2 & 1.2 & 86.1 & 50.8 & 23.0 & 24.8 & 1.4 & 100 \\
\hline & C0006E-37X-4, $18.5-20$ & WR & 291.25 & 64 & 1,120 & 322 & 91 & 2,511 & 38,119 & 23,234 & & 40.1 & 21.0 & 29.3 & -0.5 & 0.0 & 90.4 & 44.3 & 23.3 & 32.4 & 0.0 & 100 \\
\hline & $\mathrm{COO}$ & W & 29 & 69 & 1,024 & 189 & 56 & 4,248 & 35,673 & 14,424 & 1,578 & 50.9 & 19.7 & 16.8 & -2.7 & 0.0 & 87.4 & 58.2 & 22.5 & 19.3 & 0.0 & 100 \\
\hline & C0006E-37X-5, 0-1.5 & WR & 292.12 & 58 & 1,238 & 359 & 73 & 1,721 & 42,883 & 27,439 & 2,443 & 35.1 & 23.8 & 35.1 & -0.4 & 0.0 & 93.9 & 37.3 & 25.3 & 37.4 & 0.0 & 100 \\
\hline & C0006E-37X-6, 124-1 & W & & 69 & 1,016 & 247 & 101 & 3,231 & & 15,971 & & 42.1 & 19.1 & 19.3 & 0.6 & 0.6 & 81.1 & 51.9 & 23.5 & 23.8 & 0.7 & 100 \\
\hline & C0006E-37X-CC, 14-16 & w & 295.75 & 60 & 1,240 & 547 & 93 & 1,824 & 40,298 & 33,625 & 2,4 & 40.7 & 22.0 & 43.7 & -0.6 & 0.0 & 106.4 & 38.3 & 20.7 & 41.1 & 0.0 & 100 \\
\hline & C0006E-38X-2, 0-1.5 & WR & 296.70 & 74 & 1,103 & 323 & 45 & 3,031 & 37,491 & 20,667 & 1,360 & 43.3 & 20.7 & 25.7 & -2.4 & 0.0 & 89.7 & 48.3 & 23.1 & 28.6 & 0.0 & 100 \\
\hline & C0006E-38X-CC, 21-23 & W & 297.50 & 68 & 610 & 212 & 162 & 2,701 & 23,777 & 17,201 & 6,632 & 38.4 & 12.8 & 21.7 & 5.3 & 5.3 & 78.2 & 49.1 & 16.4 & 27.7 & 6.8 & 100 \\
\hline & C0006E-38X-CC, $42-43$ & w & 297.71 & 44 & 921 & 494 & 104 & 1324 & 30,798 & 30,567 & 4,369 & 34.1 & 16.6 & 40.1 & 2.7 & 2.7 & 93.4 & 36.5 & 17.8 & 42.9 & 2.9 & 100 \\
\hline & C0006E-39X-1, 131-133 & WR & 307.14 & 78 & 789 & 220 & 121 & 2,615 & 31,467 & 17,281 & 3,995 & 37.1 & 17.4 & 21.4 & 1.7 & 1.7 & 77.6 & 47.8 & 22.4 & 27.6 & 2.2 & 100 \\
\hline & C0006E-39X-3, 71-72.5 & WR & 309.36 & 72 & 982 & 238 & 69 & 3,421 & 34,962 & 16,997 & 1,894 & 44.7 & 19.3 & 20.7 & -1.7 & 0.0 & 84.6 & 52.8 & 22.8 & 24.4 & 0.0 & 100 \\
\hline & & WF & & 60 & 1,051 & 263 & 127 & & 33,798 & 17,640 & 3,9 & 41.6 & 18.6 & 21.7 & 1.2 & 1.2 & 83.2 & 50.0 & 22.4 & 26.1 & 1.5 & 100 \\
\hline & C0006E-39X-CC, 31-33 & WR & 315.66 & 48 & 940 & 301 & 119 & 2,270 & 34,906 & 22,690 & 4,156 & 37.5 & 19.2 & 28.8 & 1.9 & 1.9 & 87.3 & 42.9 & 22.0 & 33.0 & 2.1 & 100 \\
\hline & C0006E-40X-3, 29-31 & w & 318.45 & 41 & 941 & 276 & 105 & 1,897 & 30,875 & 18,268 & 3,354 & 30.8 & 17.1 & 23.0 & 1.4 & 1.4 & 72.2 & 42.6 & 23.6 & 31.9 & 1.9 & 100 \\
\hline & $x-3,51-53$ & w & & 79 & 983 & 284 & 64 & 3,348 & 39,421 & 17,331 & 2,101 & 44.0 & 21.9 & 20.9 & -1.6 & 0.0 & 86.8 & 50.7 & 25.2 & 24.1 & 0.0 & 100 \\
\hline & C0006E-40X-7, 0-1.5 & WR & 322.01 & 69 & 1,141 & 322 & 65 & 3,393 & 39,152 & 21,995 & 2,102 & 47.8 & 21.5 & 27.3 & -1.8 & 0.0 & 96.7 & 49.5 & 22.3 & 28.3 & 0.0 & 100 \\
\hline & C0006E-40X-8, 60-61.5 & WR & 323.01 & 66 & 1,190 & 329 & 82 & 3,140 & 40,743 & 20,881 & 1,875 & 44.4 & 22.6 & 25.8 & -1.9 & 0.0 & 92.8 & 47.9 & 24.3 & 27.8 & 0.0 & 100 \\
\hline
\end{tabular}




\begin{tabular}{|c|c|c|c|c|c|c|c|c|c|c|c|c|c|c|c|c|c|c|c|c|c|c|}
\hline \multirow[b]{3}{*}{ Unit } & \multirow[b]{3}{*}{$\begin{array}{l}\text { Hole, core, section, } \\
\text { interval }(\mathrm{cm})\end{array}$} & \multirow[b]{3}{*}{$\begin{array}{l}\text { Core } \\
\text { type }\end{array}$} & \multirow[b]{3}{*}{$\begin{array}{l}\text { Depth } \\
\text { CSF }(m)\end{array}$} & \multirow{2}{*}{\multicolumn{4}{|c|}{ Peak intensity (counts/step) }} & \multirow{2}{*}{\multicolumn{4}{|c|}{ Integrated peak area (total counts) }} & \multicolumn{11}{|c|}{ Abundance calculated from SVD normalization factor } \\
\hline & & & & & & & & & & & & \multicolumn{6}{|c|}{ Calculated abundance (wt\%) } & \multicolumn{5}{|c|}{ Normalized abundance (wt\%) } \\
\hline & & & & $\frac{\widehat{a}}{U}$ & $\frac{1}{0}$ & 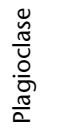 & $\frac{\stackrel{ \pm}{U}}{\frac{U}{U}}$ & $\frac{\widehat{\pi}}{U}$ & $\begin{array}{l}\frac{1}{0} \\
\frac{0}{00} \\
\text { Oे }\end{array}$ & 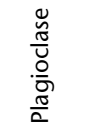 & $\frac{\stackrel{ \pm}{\frac{\pi}{N}}}{u}$ & $\frac{\vec{\sigma}}{U}$ & $\begin{array}{l}\frac{1}{0} \\
\frac{0}{2} \\
0\end{array}$ & 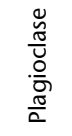 & 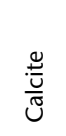 & 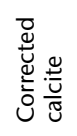 & 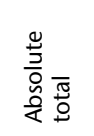 & $\frac{\widehat{\sigma}}{U}$ & $\begin{array}{l}\frac{0}{0} \\
\frac{0}{\partial} \\
\partial\end{array}$ & 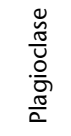 & 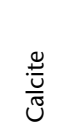 & 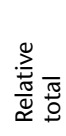 \\
\hline & C0006E-41X-2, 71-73 & W & 326.96 & 37 & 1,146 & 645 & 75 & 877 & 37,811 & 39,539 & 2,130 & 35.8 & 20.4 & 52.2 & -0.5 & 0.0 & 108.3 & 33.0 & 18.8 & 48.2 & 0.0 & 100 \\
\hline & C0006E-41X-3, 44-46 & W & 328.09 & 49 & 1,043 & 261 & 72 & 3,046 & 35,132 & 17,776 & 2,541 & 41.5 & 19.4 & 21.8 & -0.7 & 0.0 & 82.8 & 50.2 & 23.5 & 26.4 & 0.0 & 100 \\
\hline & C0006E-41X-4, 0-1.5 & WR & 328.83 & 77 & 1,001 & 214 & 75 & 3,433 & 34,644 & 15,660 & 2,621 & 43.8 & 19.2 & 18.8 & -0.8 & 0.0 & 81.8 & 53.6 & 23.4 & 23.0 & 0.0 & 100 \\
\hline & C0006E-42X-1, 118-119 & W & 335.51 & 68 & 1,008 & 245 & 115 & 3,065 & 33,070 & 16,537 & 3,548 & 41.0 & 18.3 & 20.2 & 0.8 & 0.8 & 80.2 & 51.1 & 22.8 & 25.2 & 0.9 & 100 \\
\hline & C0006E-42X-5, 0-1.5 & WR & 339.58 & 53 & 843 & 308 & 139 & 1,828 & 33,435 & 22,135 & 4,371 & 32.8 & 18.4 & 28.2 & 2.5 & 2.5 & 82.0 & 40.0 & 22.5 & 34.4 & 3.1 & 100 \\
\hline & C0006E-42X-8, 56.5-58 & WR & 343.36 & 67 & 956 & 214 & 133 & 3,827 & 32,801 & 15,244 & 4,398 & 47.6 & 18.0 & 18.2 & 1.4 & 1.4 & 85.2 & 55.9 & 21.2 & 21.4 & 1.6 & 100 \\
\hline & C0006E-43X-5, 0-1.5 & WR & 349.11 & 51 & 1,182 & 313 & 66 & 2,609 & 40,734 & 21,193 & 2,731 & 39.4 & 22.6 & 26.4 & -0.4 & 0.0 & 88.4 & 44.6 & 25.6 & 29.8 & 0.0 & 100 \\
\hline & C0006E-43X-CC, 28-29 & W & 352.36 & 54 & 628 & 172 & 178 & 2,626 & 22,327 & 12,467 & 6,891 & 34.3 & 12.2 & 15.2 & 5.9 & 5.9 & 67.7 & 50.7 & 18.0 & 22.5 & 8.8 & 100 \\
\hline & C0006E-44X-3, 117-119 & WR & 357.34 & 83 & 1,056 & 243 & 117 & 3,043 & 33,423 & 18,390 & 3,532 & 42.1 & 18.4 & 22.7 & 0.7 & 0.7 & 83.9 & 50.2 & 21.9 & 27.1 & 0.8 & 100 \\
\hline & C0006E-44X-5, 0-1.5 & WR & 358.99 & 59 & 997 & 285 & 73 & 2,442 & 36,826 & 20,786 & 1,653 & 37.6 & 20.4 & 26.0 & -1.5 & 0.0 & 84.0 & 44.8 & 24.2 & 31.0 & 0.0 & 100 \\
\hline & C0006E-45X-1, 37.5-39 & WR & 363.21 & 70 & 1,044 & 263 & 71 & 3,096 & 35,818 & 19,151 & 2,326 & 43.0 & 19.7 & 23.7 & -1.0 & 0.0 & 86.4 & 49.8 & 22.9 & 27.4 & 0.0 & 100 \\
\hline & C0006E-45X-3, 63.5-65 & WR & 366.27 & 75 & 1,091 & 248 & 101 & 3,144 & 34,647 & 16,589 & 3,668 & 41.7 & 19.2 & 20.2 & 0.8 & 0.8 & 81.9 & 51.0 & 23.4 & 24.7 & 1.0 & 100 \\
\hline & C0006E-45X-3, 81.5-83 & WR & 366.45 & 77 & 1,129 & 312 & 67 & 3,803 & 39,621 & 21,240 & 1,870 & 51.3 & 21.8 & 26.1 & -2.4 & 0.0 & 99.2 & 51.7 & 22.0 & 26.3 & 0.0 & 100 \\
\hline & C0006E-45X-4, 0-1.5 & WR & 366.66 & 70 & 1,120 & 253 & 80 & 3,063 & 37,721 & 19,611 & 2,013 & 42.9 & 20.9 & 24.2 & -1.5 & 0.0 & 88.0 & 48.8 & 23.7 & 27.5 & 0.0 & 100 \\
\hline & C0006E-45X-7, 102-103 & W & 370.90 & 61 & 1,286 & 538 & 89 & 1,543 & 42,631 & 35,678 & 1,991 & 39.3 & 23.3 & 46.5 & -1.1 & 0.0 & 109.1 & 36.0 & 21.4 & 42.6 & 0.0 & 100 \\
\hline & C0006E-45X-8, 50-51 & W & 371.80 & 76 & 756 & 192 & 92 & 3,164 & 27,147 & 15,752 & 2,933 & 41.6 & 14.8 & 19.4 & 0.1 & 0.1 & 75.9 & 54.8 & 19.5 & 25.5 & 0.1 & 100 \\
\hline & C0006E-46X-1, 0-5 & W & 372.33 & 39 & 89 & 64 & 43 & 1,106 & 2,947 & 2,892 & 756 & 12.9 & 1.4 & 3.5 & 0.0 & 0.0 & 17.9 & 72.4 & 8.0 & 19.6 & 0.0 & 100 \\
\hline & C0006E-46X-3, 107-108 & W & 376.24 & 67 & 932 & 312 & 101 & 3,084 & 33,672 & 21,360 & 4,013 & 44.6 & 18.4 & 26.8 & 1.2 & 1.2 & 91.0 & 49.1 & 20.2 & 29.4 & 1.3 & 100 \\
\hline & C0006E-46X-3, 138-140 & WR & 376.55 & 62 & 1,245 & 338 & 72 & 2,602 & 39,252 & 25,301 & 2,420 & 42.4 & 21.6 & 32.1 & -0.9 & 0.0 & 96.1 & 44.1 & 22.5 & 33.4 & 0.0 & 100 \\
\hline & C0006E-46X-5, 0-1.5 & WR & 377.60 & 77 & 1,279 & 365 & 88 & 2,690 & 41,256 & 24,925 & 2,739 & 42.9 & 22.8 & 31.4 & -0.6 & 0.0 & 97.1 & 44.2 & 23.4 & 32.4 & 0.0 & 100 \\
\hline & C0006E-47X-3, 53-54 & W & 385.18 & 67 & 1,170 & 255 & 105 & 3,094 & 35,873 & 18,344 & 4,155 & 42.5 & 19.8 & 22.5 & 1.4 & 1.4 & 86.2 & 49.3 & 23.0 & 26.2 & 1.6 & 100 \\
\hline & C0006E-47X-3, 93-94.5 & WR & 385.58 & 65 & 1,107 & 318 & 126 & 2,892 & 33,648 & 22,228 & 4,944 & 43.4 & 18.4 & 28.0 & 2.5 & 2.5 & 92.3 & 47.0 & 19.9 & 30.4 & 2.7 & 100 \\
\hline & C0006E-47X-4, 14.5-16 & WR & 386.20 & 60 & 924 & 244 & 202 & 2,861 & 32,317 & 17,227 & 7,498 & 39.6 & 17.8 & 21.2 & 6.1 & 6.1 & 84.8 & 46.8 & 21.0 & 25.0 & 7.2 & 100 \\
\hline & C0006E-47X-5, 0 & WR & 386.72 & 77 & 1,156 & 299 & 86 & 3,251 & 38,637 & 22,109 & 2,942 & 46.6 & 21.3 & 27.5 & -0.6 & 0.0 & 95.4 & 48.8 & 22.3 & 28.9 & 0.0 & 100 \\
\hline & C0006E-48X-1, 70-72 & W & 392.03 & 56 & 1,199 & 323 & 151 & 2,842 & 38,485 & 21,025 & 4,009 & 41.8 & 21.3 & 26.2 & 1.2 & 1.2 & 90.4 & 46.2 & 23.5 & 28.9 & 1.3 & 100 \\
\hline \multirow[t]{14}{*}{ IID } & C0006F-1R-1, 130-132 & W & 396.30 & 79 & 1,089 & 228 & 54 & 3,512 & 37,830 & 17,587 & 1,493 & 45.8 & 20.9 & 21.3 & -2.5 & 0.0 & 88.1 & 52.0 & 23.8 & 24.2 & 0.0 & 100 \\
\hline & C0006 & WR & 396.98 & 64 & 1,099 & 333 & 91 & 3,385 & 37,436 & 21,124 & 2,566 & 47.2 & 20.6 & 26.2 & -1.1 & 0.0 & 94.0 & 50.2 & 21.9 & 27.9 & 0.0 & 100 \\
\hline & C0006E-49X-3, 95-97 & W & 404.60 & 70 & 1,204 & 297 & 65 & 2,919 & 38,158 & 20,312 & 2,535 & 42.0 & 21.1 & 25.2 & -0.8 & 0.0 & 88.3 & 47.6 & 23.9 & 28.5 & 0.0 & 100 \\
\hline & C0006E-49X-4, 0-1.5 & WR & 404.68 & 66 & 1,235 & 312 & 75 & 3,257 & 39,817 & 22,615 & 2,132 & 46.9 & 21.9 & 28.2 & -1.7 & 0.0 & 97.0 & 48.4 & 22.6 & 29.0 & 0.0 & 100 \\
\hline & C0006F-2R-2, 0-1.5 & WR & 405.52 & 72 & 1, & 29 & 6 & 2,837 & 41,370 & 20,857 & 25 & 41.4 & 23.0 & 25.8 & -0.9 & 0.0 & 90 & 45. & 25.5 & 28.6 & 0.0 & 100 \\
\hline & C0006F-2R-3, $2 \varepsilon$ & w & 406.19 & 70 & 1,147 & 263 & 57 & 3,091 & 38,270 & 21,009 & 2,268 & 44.2 & 21.1 & 26.1 & -1.3 & 0.0 & 91.4 & 48.3 & 23.1 & 28.6 & 0.0 & 100 \\
\hline & C0006F-3R-1, 0-1.5 & WR & 414.00 & 65 & 1,218 & 256 & 94 & 3,132 & 37,918 & 18,651 & 3,328 & 42.9 & 21.0 & 22.9 & 0.2 & 0.2 & 87.0 & 49.4 & 24.2 & 26.3 & 0.2 & 100 \\
\hline & & W & & 66 & 875 & 211 & 105 & & 32,899 & 16,246 & & 44.7 & 18.1 & 19.7 & 0.8 & 0 & 83.2 & 53.7 & 21.8 & 23.7 & 0.9 & 100 \\
\hline & $-4 R-1,8$ & W & 4 & 1 & 1,291 & 249 & 69 & 3 & 39,766 & 17,605 & 18 & 46.2 & 22.1 & 21.2 & -2.1 & 0.0 & 89.5 & 51.7 & 24.6 & 23.7 & 0.0 & 100 \\
\hline & C0006F-4R-2, 33-34.5 & WR & 425.24 & 66 & 972 & 217 & 108 & 3,952 & 33,434 & 16,048 & 3,484 & 49.4 & 18.3 & 19.3 & 0.0 & 0.0 & 87.0 & 56.7 & 21.1 & 22.1 & 0.0 & 100 \\
\hline & C0006F-5R-1, 117-118. & WR & 434.17 & 67 & 1,132 & 226 & 56 & 2,978 & 36,503 & 18,254 & 1,810 & 41.1 & 20.2 & 22.4 & -1.6 & 0.0 & 83.7 & 49.1 & 24.1 & 26.8 & 0.0 & 100 \\
\hline & C0006F-6R-1, 120-121.5 & WR & 439.20 & 71 & 789 & 167 & 265 & 3,710 & 26,227 & 12,760 & 9,340 & 45.2 & 14.3 & 15.1 & 8.2 & 8.2 & 82.8 & 54.5 & 17.3 & 18.3 & 9.9 & 100 \\
\hline & C0006F-7R-1, 10-11 & W & 447.60 & 82 & 890 & 231 & 216 & 4,129 & 29,342 & 12,974 & 6,831 & 49.2 & 16.1 & 15.2 & 4.5 & 4.5 & 84.9 & 57.9 & 18.9 & 17.9 & 5.3 & 100 \\
\hline & C0006F-7R-1, 90-91.5 & WR & 448.40 & 69 & 784 & 168 & 251 & 3,718 & 25,800 & 10,527 & 10,951 & 43.7 & 14.2 & 12.1 & 10.4 & 10.4 & 80.3 & 54.4 & 17.6 & 15.0 & 12.9 & 100 \\
\hline \multirow[t]{7}{*}{ III } & C0006F-8R-1, 12.5-14 & WR & 457.13 & 93 & 1,077 & 182 & 48 & 5,552 & 35,419 & 12,488 & 1,550 & 62.4 & 19.4 & 13.8 & -3.6 & 0.0 & 95.7 & 65.3 & 20.3 & 14.5 & 0.0 & 100 \\
\hline & C0006F-8R-1, 50-51 & W & 457.50 & 69 & 1,009 & 198 & 60 & 5,007 & 32,666 & 13,230 & 1,253 & 57.7 & 17.8 & 15.1 & -3.6 & 0.0 & 90.7 & 63.6 & 19.7 & 16.7 & 0.0 & 100 \\
\hline & C0006F-8R-1, 103-104.5 & WR & 458.03 & 88 & 1,049 & 229 & 48 & 5,125 & 34,510 & 14,402 & 1,004 & 59.6 & 18.9 & 16.6 & -4.1 & 0.0 & 95.1 & 62.7 & 19.8 & 17.5 & 0.0 & 100 \\
\hline & C0006F-8R-2, 42.5-44 & WR & 458.84 & 84 & 864 & 241 & 157 & 5,052 & 28,535 & 12,675 & 6,546 & 58.1 & 15.4 & 14.5 & 3.5 & 3.5 & 91.6 & 63.5 & 16.9 & 15.9 & 3.8 & 100 \\
\hline & C0006F-9R-1, 53.5-55 & WR & 467.04 & 94 & 961 & 179 & 52 & 6,016 & 31,322 & 12,614 & 1,053 & 67.3 & 16.9 & 14.1 & -4.5 & 0.0 & 98.3 & 68.5 & 17.2 & 14.3 & 0.0 & 100 \\
\hline & C0006F-9R-1, 105.5-106 & WR & 467.56 & 98 & 953 & 190 & 151 & 4,803 & 30,754 & 12,115 & 4,954 & 55.1 & 16.8 & 13.7 & 1.5 & 1.5 & 87.2 & 63.2 & 19.3 & 15.8 & 1.8 & 100 \\
\hline & C0006F-9R-1, 105.5-106 & WR & 467.56 & 73 & 653 & 158 & 127 & 3,977 & 22,600 & 9,296 & 4,382 & 45.2 & 12.3 & 10.5 & 1.8 & 1.8 & 69.8 & 64.8 & 17.6 & 15.1 & 2.5 & 100 \\
\hline
\end{tabular}




\begin{tabular}{|c|c|c|c|c|c|c|c|c|c|c|c|c|c|c|c|c|c|c|c|c|c|c|}
\hline \multirow[b]{3}{*}{ Unit } & \multirow[b]{3}{*}{$\begin{array}{l}\text { Hole, core, section, } \\
\text { interval }(\mathrm{cm})\end{array}$} & \multirow[b]{3}{*}{$\begin{array}{l}\text { Core } \\
\text { type }\end{array}$} & \multirow[b]{3}{*}{$\begin{array}{l}\text { Depth } \\
\text { CSF }(m)\end{array}$} & \multirow{2}{*}{\multicolumn{4}{|c|}{ Peak intensity (counts/step) }} & \multirow{2}{*}{\multicolumn{4}{|c|}{ Integrated peak area (total counts) }} & \multicolumn{11}{|c|}{ Abundance calculated from SVD normalization factor } \\
\hline & & & & & & & & & & & & \multicolumn{6}{|c|}{ Calculated abundance (wt\%) } & \multicolumn{5}{|c|}{ Normalized abundance (wt\%) } \\
\hline & & & & $\frac{\vec{\theta}}{U}$ & $\begin{array}{l}\frac{1}{0} \\
\frac{0}{0} \\
0\end{array}$ & 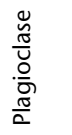 & 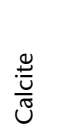 & $\frac{\vec{\sigma}}{U}$ & $\begin{array}{l}\frac{1}{0} \\
\text { O⿱艹 } \\
0\end{array}$ & 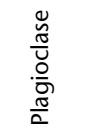 & 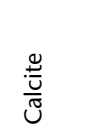 & $\frac{\widehat{\pi}}{U}$ & 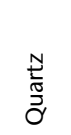 & 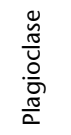 & 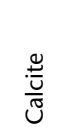 & 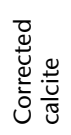 & 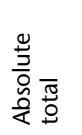 & $\frac{\vec{\pi}}{U}$ & $\begin{array}{l}\frac{1}{2} \\
\frac{\pi}{2} \\
O^{\prime}\end{array}$ & $\begin{array}{l}\stackrel{0}{0} \\
\frac{\pi}{\square} \\
\frac{0}{9} \\
\frac{\pi}{2}\end{array}$ & 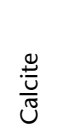 & 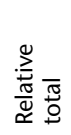 \\
\hline & C0006F-9R-2, 41.5-43 & WR & 468.42 & 74 & 1,167 & 247 & 80 & 5,423 & 37,194 & 14,063 & 2,609 & 62.3 & 20.4 & 15.9 & -2.3 & 0.0 & 98.6 & 63.1 & 20.7 & 16.2 & 0.0 & 100 \\
\hline & C0006F-10R-1, 27.5-29 & WR & 476.28 & 83 & 935 & 171 & 60 & 5,504 & 32,107 & 11,648 & 1,409 & 61.5 & 17.5 & 12.8 & -3.6 & 0.0 & 91.8 & 66.9 & 19.1 & 14.0 & 0.0 & 100 \\
\hline & C0006F-10R-1, 89-90 & W & 476.89 & 82 & 922 & 191 & 58 & 5,557 & 32,254 & 13,280 & 1,466 & 63.2 & 17.5 & 15.1 & -3.7 & 0.0 & 95.8 & 66.0 & 18.3 & 15.7 & 0.0 & 100 \\
\hline & C0006F-10R-1, $124.5-126$ & WR & 477.25 & 79 & 931 & 171 & 21 & 5,006 & 29,953 & 11,452 & 1,706 & 56.5 & 16.3 & 12.8 & -2.8 & 0.0 & 85.7 & 66.0 & 19.1 & 15.0 & 0.0 & 100 \\
\hline & C0006F-11R-1, 0-1.5 & WR & 485.50 & 103 & 944 & 218 & 54 & 5,480 & 33,890 & 13,193 & 1,365 & 62.3 & 18.5 & 14.9 & -3.8 & 0.0 & 95.7 & 65.1 & 19.3 & 15.6 & 0.0 & 100 \\
\hline & C0006F-11R-1, 60-61.5 & WR & 486.10 & 91 & 952 & 186 & 67 & 5,790 & 33,086 & 12,809 & 1,851 & 65.1 & 18.0 & 14.3 & -3.3 & 0.0 & 97.4 & 66.9 & 18.5 & 14.7 & 0.0 & 100 \\
\hline & C0006F-11R-2, 46-47.5 & WR & 487.48 & 74 & 1,022 & 218 & 64 & 3,941 & 34,656 & 14,653 & 2,491 & 48.1 & 19.1 & 17.3 & -1.3 & 0.0 & 84.6 & 56.9 & 22.6 & 20.5 & 0.0 & 100 \\
\hline & C0006F-11R-CC, 19.5-21 & WR & 488.01 & 89 & 742 & 172 & 101 & 4,631 & 32,181 & 12,017 & 3,423 & 53.2 & 17.7 & 13.6 & -0.4 & 0.0 & 84.5 & 63.0 & 20.9 & 16.1 & 0.0 & 100 \\
\hline & C0006F-12R-1, 62.5-64 & WR & 495.63 & 85 & 958 & 209 & 39 & 5,241 & 33,356 & 12,166 & 1,408 & 59.2 & 18.3 & 13.6 & -3.5 & 0.0 & 91.0 & 65.0 & 20.1 & 14.9 & 0.0 & 100 \\
\hline & C0006F-12R-2, 0-1.5 & WR & 496.44 & 86 & 996 & 207 & 47 & 4,314 & 34,687 & 13,422 & 1,599 & 50.9 & 19.1 & 15.5 & -2.7 & 0.0 & 85.5 & 59.5 & 22.4 & 18.1 & 0.0 & 100 \\
\hline & C0006F-13R-1, 119-120.5 & WR & 505.69 & 84 & 940 & 203 & 74 & 5,236 & 33,807 & 11,997 & 2,585 & 59.1 & 18.5 & 13.3 & -2.0 & 0.0 & 90.9 & 65.0 & 20.4 & 14.7 & 0.0 & 100 \\
\hline & C0006F-13R-2, 20-21.5 & WR & 506.10 & 108 & 1,007 & 148 & 74 & 5,655 & 32,024 & 11,074 & 2,418 & 62.6 & 17.5 & 12.0 & -2.4 & 0.0 & 92.1 & 68.0 & 19.0 & 13.1 & 0.0 & 100 \\
\hline & C0006F-13R-2, 47-50 & W & 506.37 & 36 & 130 & 57 & 344 & 342 & 2,760 & 2,018 & 28,364 & 5.9 & 1.6 & 2.4 & 36.7 & 36.7 & 46.6 & 12.7 & 3.4 & 5.2 & 78.7 & 100 \\
\hline & C0006F-13R-2, 86-87.5 & WR & 506.76 & 75 & 1,017 & 209 & 56 & 5,512 & 33,540 & 13,190 & 2,435 & 62.7 & 18.3 & 14.9 & -2.4 & 0.0 & 95.8 & 65.4 & 19.1 & 15.5 & 0.0 & 100 \\
\hline & C0006F-14R-1, 104-105.5 & WR & 515.04 & 72 & 916 & 165 & 58 & 4,624 & 29,545 & 12,746 & 2,139 & 53.7 & 16.1 & 14.7 & -2.0 & 0.0 & 84.6 & 63.5 & 19.0 & 17.4 & 0.0 & 100 \\
\hline & C0006F-14R-1, 111-113 & W & 515.11 & 81 & 1,050 & 189 & 78 & 4,792 & 35,923 & 12,255 & 2,498 & 54.7 & 19.8 & 13.7 & -1.8 & 0.0 & 88.3 & 62.0 & 22.5 & 15.5 & 0.0 & 100 \\
\hline & C0006F-14R-2, 0-1.5 & WR & 515.51 & 72 & 782 & 147 & 75 & 4,418 & 24,613 & 11,358 & 1,864 & 50.9 & 13.3 & 13.1 & -2.0 & 0.0 & 77.3 & 65.8 & 17.2 & 17.0 & 0.0 & 100 \\
\hline & C0006F-14R-2, 37-38.5 & WR & 515.88 & 96 & 902 & 203 & 50 & 4,561 & 33,368 & 13,206 & 2,006 & 53.3 & 18.3 & 15.2 & -2.3 & 0.0 & 86.8 & 61.4 & 21.1 & 17.5 & 0.0 & 100 \\
\hline & C0006F-14R-3, 22.5-24 & WR & 517.24 & 86 & 822 & 184 & 69 & 4,939 & 28,364 & 10,608 & 2,522 & 55.4 & 15.4 & 11.8 & -1.6 & 0.0 & 82.6 & 67.1 & 18.7 & 14.2 & 0.0 & 100 \\
\hline & C0006F-15R-1, 0-1.5 & WR & 523.50 & 79 & 1,077 & 226 & 56 & 5,396 & 34,955 & 13,415 & 1,584 & 61.6 & 19.1 & 15.2 & -3.5 & 0.0 & 95.9 & 64.2 & 19.9 & 15.8 & 0.0 & 100 \\
\hline & C0006F-15R-1, 35-37 & W & 523.85 & 75 & 1,024 & 190 & 66 & 5,201 & 36,528 & 13,059 & 2,322 & 59.3 & 20.1 & 14.7 & -2.4 & 0.0 & 94.1 & 63.1 & 21.4 & 15.6 & 0.0 & 100 \\
\hline & C0006F-15R-1, 121-122.5 & WR & 524.71 & 100 & 989 & 204 & 71 & 5,183 & 32,615 & 12,987 & 2,825 & 59.3 & 17.8 & 14.7 & -1.6 & 0.0 & 91.9 & 64.6 & 19.4 & 16.1 & 0.0 & 100 \\
\hline & C0006F-15R-2, 57-58.5 & WR & 525.57 & 87 & 952 & 151 & 49 & 5,325 & 32,833 & 10,514 & 1,737 & 58.9 & 18.0 & 11.3 & -3.1 & 0.0 & 88.2 & 66.8 & 20.4 & 12.8 & 0.0 & 100 \\
\hline & C0006F-16R-1, 22-24 & W & 533.22 & 101 & 1,142 & 185 & 71 & 5,741 & 35,942 & 12,069 & 2,502 & 64.0 & 19.7 & 13.2 & -2.5 & 0.0 & 96.9 & 66.1 & 20.3 & 13.6 & 0.0 & 100 \\
\hline & C0006F-16R-1, 100-10 & WR & 534.00 & 68 & 970 & 156 & 86 & 4,624 & 32,616 & 10,717 & 2,415 & 52.1 & 18.0 & 11.8 & -1.7 & 0.0 & 81.9 & 63.6 & 22.0 & 14.4 & 0.0 & 100 \\
\hline & C0006F-17R-1, 15-16.5 & WR & 542.65 & 68 & 1,228 & 176 & 50 & 5,257 & 35,650 & 11,232 & 1,751 & 58.6 & 19.6 & 12.2 & -3.1 & 0.0 & 90.4 & 64.8 & 21.7 & 13.5 & 0.0 & 100 \\
\hline & C0006F-17R-CC, 9-12 & W & 544.47 & 90 & 936 & 173 & 77 & 5,850 & 33,854 & 12,372 & 3,196 & 65.4 & 18.5 & 13.7 & -1.6 & 0.0 & 97.5 & 67.1 & 18.9 & 14.0 & 0.0 & 100 \\
\hline & C0006F-18R-1, 10-12 & W & 552.10 & 99 & 955 & 216 & 55 & 5,737 & 34,787 & 12,011 & 1,155 & 63.9 & 19.0 & 13.2 & -4.2 & 0.0 & 96.1 & 66.5 & 19.8 & 13.7 & 0.0 & 100 \\
\hline & C0006F-18R-1, 113-114.5 & WR & 553.13 & 73 & 954 & 184 & 98 & 5,146 & 32,768 & 12,137 & 3,651 & 58.4 & 17.9 & 13.6 & -0.5 & 0.0 & 89.9 & 64.9 & 20.0 & 15.1 & 0.0 & 100 \\
\hline & C0006F-19R-1, $122.5-124$ & WR & 562.73 & 103 & 894 & 169 & 64 & 5,674 & 33,402 & 10,514 & 1,915 & 62.3 & 18.3 & 11.2 & -3.1 & 0.0 & 91.8 & 67.9 & 19.9 & 12.2 & 0.0 & 100 \\
\hline & C0006F-19R-2, 78.5-80 & WR & 563.69 & 88 & 887 & 214 & 61 & 4,735 & 33,779 & 12,188 & 2,095 & 54.2 & 18.6 & 13.7 & -2.2 & 0.0 & 86.5 & 62.7 & 21.5 & 15.9 & 0.0 & 100 \\
\hline & C0006F-19R-3, 0-1.5 & WR & 564.31 & 81 & 907 & 192 & 62 & 4,907 & 34,492 & 12,167 & 1,831 & 55.9 & 19.0 & 13.6 & -2.7 & 0.0 & 88.5 & 63.1 & 21.5 & 15.4 & 0.0 & 100 \\
\hline & C0006F-19R-3, 43.5-45 & WR & 564.75 & 85 & 1,120 & 200 & 90 & 5,219 & 35,560 & 11,742 & 3,009 & 58.6 & 19.6 & 12.9 & -1.4 & 0.0 & 91.1 & 64.4 & 21.5 & 14.1 & 0.0 & 100 \\
\hline & C0006F-19R-4, 8-10 & W & 565.80 & 90 & 947 & 191 & 67 & 5,436 & 33,768 & 10,179 & 1,800 & 59.7 & 18.6 & 10.8 & -3.1 & 0.0 & 89.0 & 67.1 & 20.8 & 12.1 & 0.0 & 100 \\
\hline & C0006F-19R-CC, 13.5-15 & WR & 567.84 & 73 & 975 & 152 & 44 & 5,429 & 30,980 & 10,121 & 1,070 & 59.7 & 16.9 & 10.8 & -3.9 & 0.0 & 87.4 & 68.3 & 19.4 & 12.4 & 0.0 & 100 \\
\hline & C0006F-20R-1, 0-1.5 & WR & 571.00 & 107 & 1,031 & 139 & 51 & 5,664 & 34,415 & 10,499 & 1,543 & 62.1 & 18.9 & 11.1 & -3.6 & 0.0 & 92.1 & 67.4 & 20.5 & 12.1 & 0.0 & 100 \\
\hline & C0006F-20R-1, 10-12 & W & 571.10 & 14 & 77 & 44 & 911 & 616 & 2,518 & 1,467 & 39,147 & 8.7 & 1.4 & 1.6 & 50.6 & 50.6 & 62.3 & 14.0 & 2.3 & 2.5 & 81.2 & 100 \\
\hline & C0006F-20R-2, 36-37 & w & 572.77 & 91 & 975 & 200 & 48 & 5,724 & 36,977 & 11,154 & 986 & 63.1 & 20.4 & 11.9 & -4.5 & 0.0 & 95.3 & 66.2 & 21.4 & 12.5 & 0.0 & 100 \\
\hline & C0006F-22R-1, 0-1.5 & WR & 590.00 & 82 & 807 & 137 & 181 & 4,834 & 27,896 & 8,923 & 11,340 & 53.5 & 15.3 & 9.5 & 10.1 & 10.1 & 88.3 & 60.6 & 17.3 & 10.7 & 11.4 & 100 \\
\hline & C0006F-23R-1, 49-50.5 & WR & 593.99 & 92 & 850 & 174 & 83 & 5,368 & 32,520 & 11,569 & 2,827 & 60.1 & 17.8 & 12.8 & -1.7 & 0.0 & 90.7 & 66.3 & 19.6 & 14.1 & 0.0 & 100 \\
\hline & C0006F-23R-1, 74-76 & W & 594.24 & 91 & 878 & 165 & 164 & 5,021 & 31,617 & 10,612 & 6,081 & 56.2 & 17.4 & 11.6 & 2.9 & 2.9 & 88.0 & 63.9 & 19.7 & 13.2 & 3.3 & 100 \\
\hline
\end{tabular}

Notes: CSF = core depth below seafloor. SVD = singular value decomposition. WR $=$ whole-round, $\mathrm{W}=$ working half. 
Table T5. XRD mineralogy by unit. (See table note.)

\begin{tabular}{|c|c|c|c|c|}
\hline Mineral & Maximum & Minimum & Average & $\begin{array}{l}\text { Standard } \\
\text { deviation }\end{array}$ \\
\hline \multicolumn{5}{|l|}{ Unit I } \\
\hline Clay & 52.7 & 27.9 & 39.5 & 6.5 \\
\hline Quartz & 32.9 & 19.1 & 26.3 & 3.2 \\
\hline Plagioclase & 47.3 & 24.1 & 33.0 & 6.7 \\
\hline Calcite & 7.5 & 0.0 & 1.2 & 2.1 \\
\hline Calcite & 7.5 & 0.2 & 3.2 & 2.4 \\
\hline \multicolumn{5}{|l|}{ Subunit IIA } \\
\hline Clay & 55.0 & 28.5 & 42.3 & 6.6 \\
\hline Quartz & 28.6 & 20.4 & 24.1 & 2.5 \\
\hline Plagioclase & 46.1 & 21.0 & 33.4 & 6.9 \\
\hline Calcite & 2.7 & 0.0 & 0.2 & 0.6 \\
\hline Calcite & 2.7 & 0.5 & 1.5 & 1.0 \\
\hline \multicolumn{5}{|l|}{ Subunit IIB } \\
\hline Clay & 52.3 & 31.9 & 43.1 & 6.7 \\
\hline Quartz & 26.9 & 22.2 & 25.4 & 1.7 \\
\hline Plagioclase & 41.6 & 22.8 & 31.5 & 7.4 \\
\hline Calcite & 0.0 & 0.0 & 0.0 & 0.0 \\
\hline Calcite & 0.0 & 0.0 & 0.0 & 0.0 \\
\hline \multicolumn{5}{|l|}{ Subunit IIC } \\
\hline Clay & 74.7 & 30.6 & 46.5 & 7.9 \\
\hline Quartz & 29.6 & 7.5 & 22.7 & 3.5 \\
\hline Plagioclase & 51.8 & 13.5 & 30.0 & 7.4 \\
\hline Calcite & 12.2 & 0.0 & 0.8 & 2.0 \\
\hline Calcite & 12.2 & 0.1 & 2.7 & 2.9 \\
\hline \multicolumn{5}{|l|}{ Subunit IID } \\
\hline Clay & 57.9 & 45.9 & 51.1 & 3.7 \\
\hline Quartz & 25.5 & 17.3 & 22.3 & 2.5 \\
\hline Plagioclase & 29.0 & 15.0 & 24.6 & 4.5 \\
\hline Calcite & 12.9 & 0.0 & 2.0 & 4.1 \\
\hline Calcite & 12.9 & 0.2 & 5.1 & 5.3 \\
\hline \multicolumn{5}{|l|}{ Unit III } \\
\hline Clay & 68.5 & 56.9 & 64.7 & 2.4 \\
\hline Quartz & 22.6 & 16.9 & 19.9 & 1.4 \\
\hline Plagioclase & 20.5 & 10.7 & 14.9 & 1.8 \\
\hline Calcite & 11.4 & 0.0 & 0.5 & 1.8 \\
\hline Calcite & 11.4 & 1.8 & 4.5 & 3.9 \\
\hline
\end{tabular}

Note: For each subunit, calcite results are first presented for all samples, and then for only those samples containing calcite. 
Table T6. Occurrence of carbonate-cemented ash, Site C0006. (See table notes.)

\begin{tabular}{|c|c|c|c|c|c|c|c|c|c|}
\hline \multirow{2}{*}{$\begin{array}{l}\text { Core, section, } \\
\text { interval }(\mathrm{cm})\end{array}$} & \multirow{2}{*}{$\begin{array}{l}\text { Depth } \\
\text { CSF }(m)\end{array}$} & \multirow{2}{*}{$\begin{array}{l}\text { Rubble/ } \\
\text { In situ }\end{array}$} & \multirow[b]{2}{*}{ XRD } & \multirow[b]{2}{*}{ Description } & \multicolumn{5}{|c|}{ Mineral composition (\%) } \\
\hline & & & & & Clay & Quartz & Plagioclase & Calcite & Total \\
\hline \multicolumn{10}{|l|}{ 316-C0006E- } \\
\hline $30 X-1,0-5$ & 220.33 & Rubble & & $\begin{array}{l}\text { First occurrence in core? Noted by driller; } \\
\text { includes small amount of interlaminated } \\
\text { mud. }\end{array}$ & & & & & \\
\hline $34 X-1,0-5$ & 258.33 & Rubble & Dolomite & $\begin{array}{l}3 \text { fragments; } 1 \text { includes interlaminated } \\
\text { mud. }\end{array}$ & 17.6 & 1.8 & 3.2 & 1.0 & 23.6 \\
\hline $38 X-1,0-5$ & 296.33 & Rubble & & Fragment displays fine laminations. & & & & & \\
\hline $42 X-3,0-5$ & 334.33 & Rubble & & $\begin{array}{l}2 \text { fragments; both have mud-filled } \\
\text { burrows; small one shows possible } \\
\text { mineral lining. }\end{array}$ & & & & & \\
\hline $46 X-1,0-5$ & 372.33 & Rubble & Dolomite & Sample has fine laminations. & 12.9 & 1.4 & 3.5 & 0.0 & 17.9 \\
\hline $46 X-1,3-5$ & 372.30 & Rubble & & & & & & & \\
\hline $47 X-1,0-4$ & 381.83 & Rubble & & Sample has fine laminations. & & & & & \\
\hline \multicolumn{10}{|l|}{ 316-C0006F- } \\
\hline $12 \mathrm{R}-1,7-32$ & 496.40 & In situ & & Layered at top, burrows in lower part. & & & & & \\
\hline $13 R-2,47-50$ & 506.30 & In situ & Calcite & Central layer has fine laminations. & & & & & \\
\hline $15 \mathrm{R}-\mathrm{CC}, 29-30$ & 527.02 & Rubble? & & $\begin{array}{l}2 \text { fragments; both have possible mud-filled } \\
\text { burrows. }\end{array}$ & & & & & \\
\hline 20R-1, 10-12 & 571.10 & In situ? & Calcite & $\begin{array}{l}\text { Possible soft-sediment deformation in } \\
\text { laminated layer. }\end{array}$ & & & & & \\
\hline 23R-CC, 2-5 & 594.30 & Rubble? & & Two rounded pebble-size pieces. & & & & & \\
\hline
\end{tabular}

Notes: Singular value decomposition was used to compute mineral composition factors, following the procedure of Fisher and Underwood (1995). Most samples archived under sample code "316SPCHIP;" also under XRD and PP codes. CSF = core depth below seafloor. XRD = Xray diffraction. 


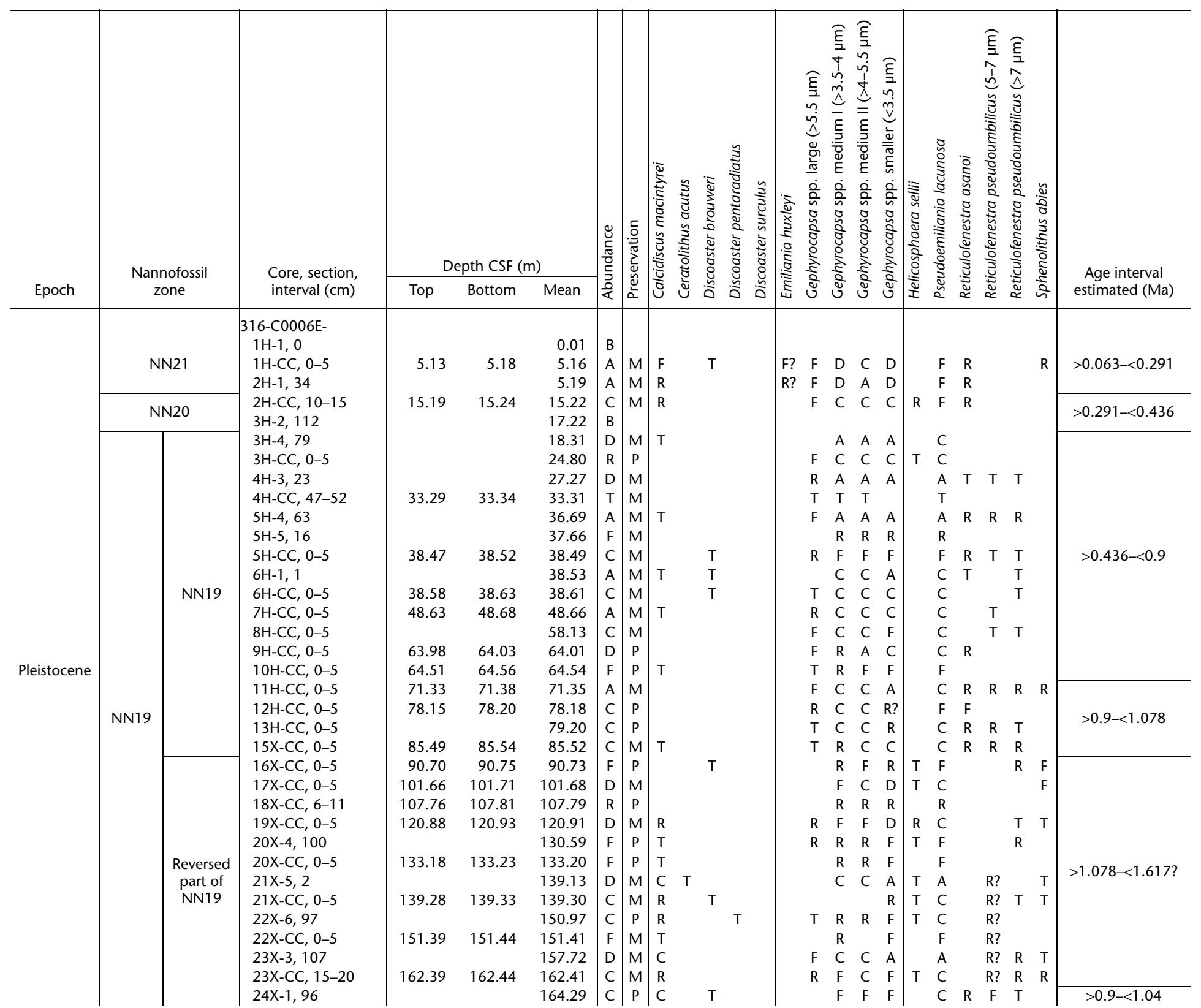




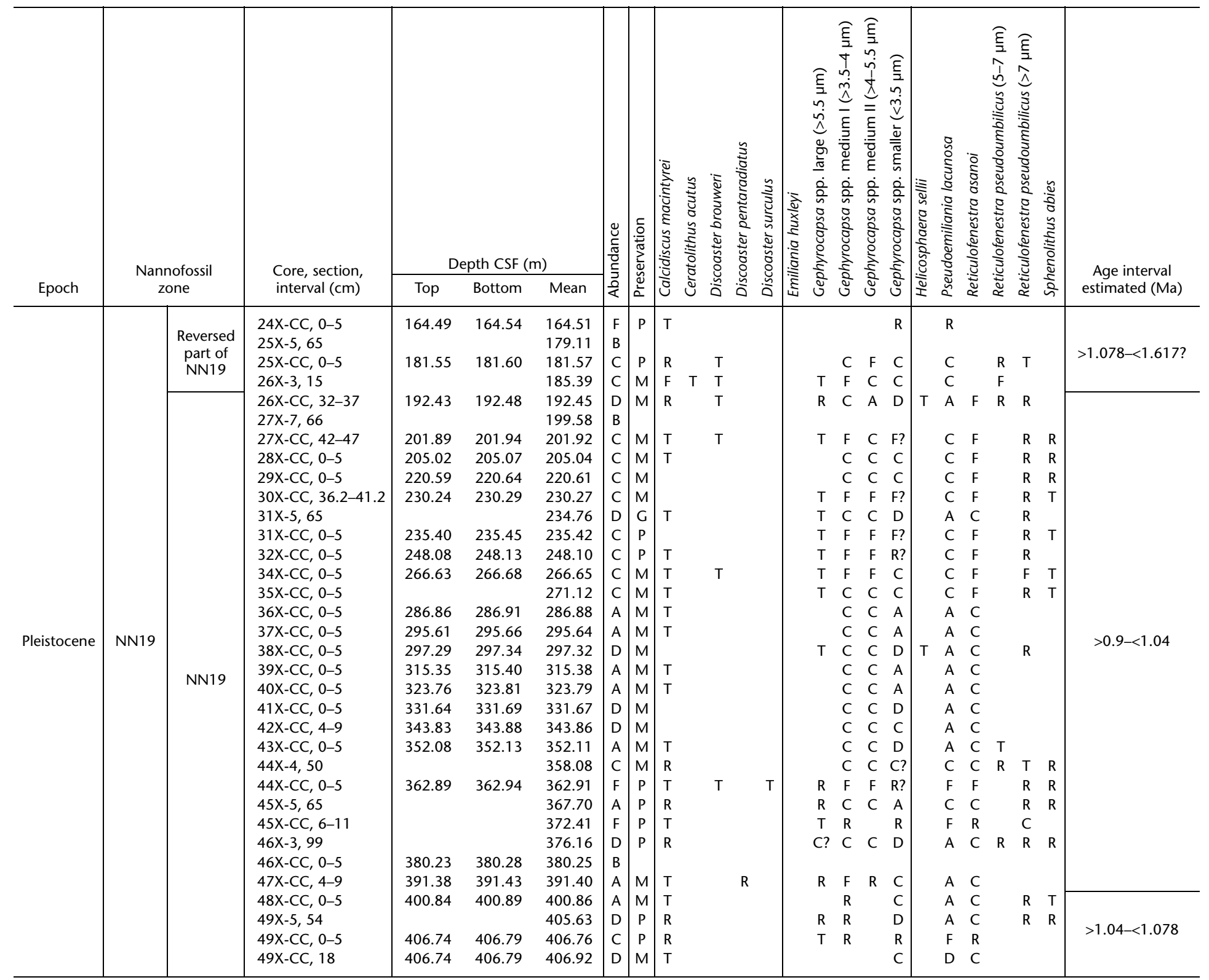




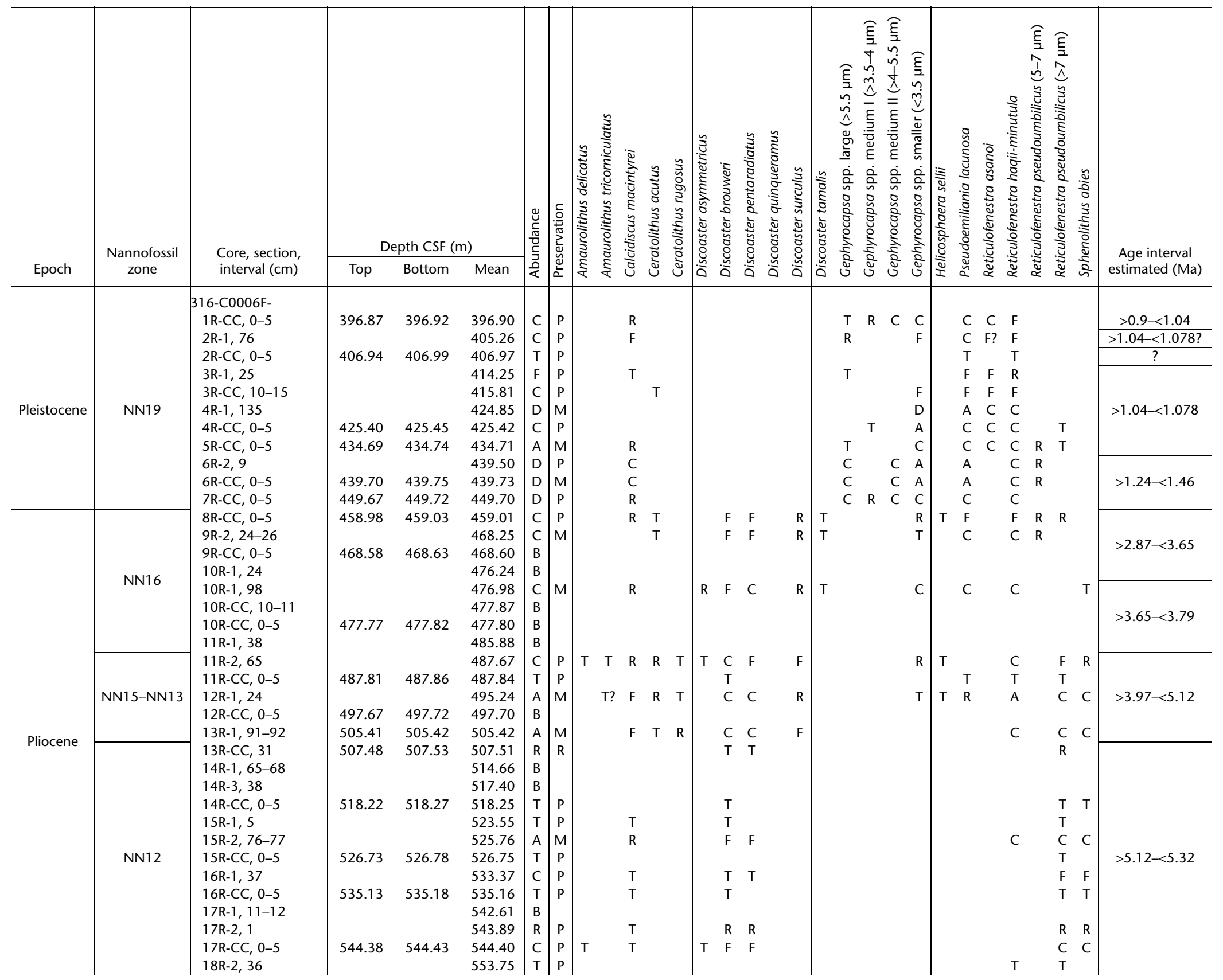




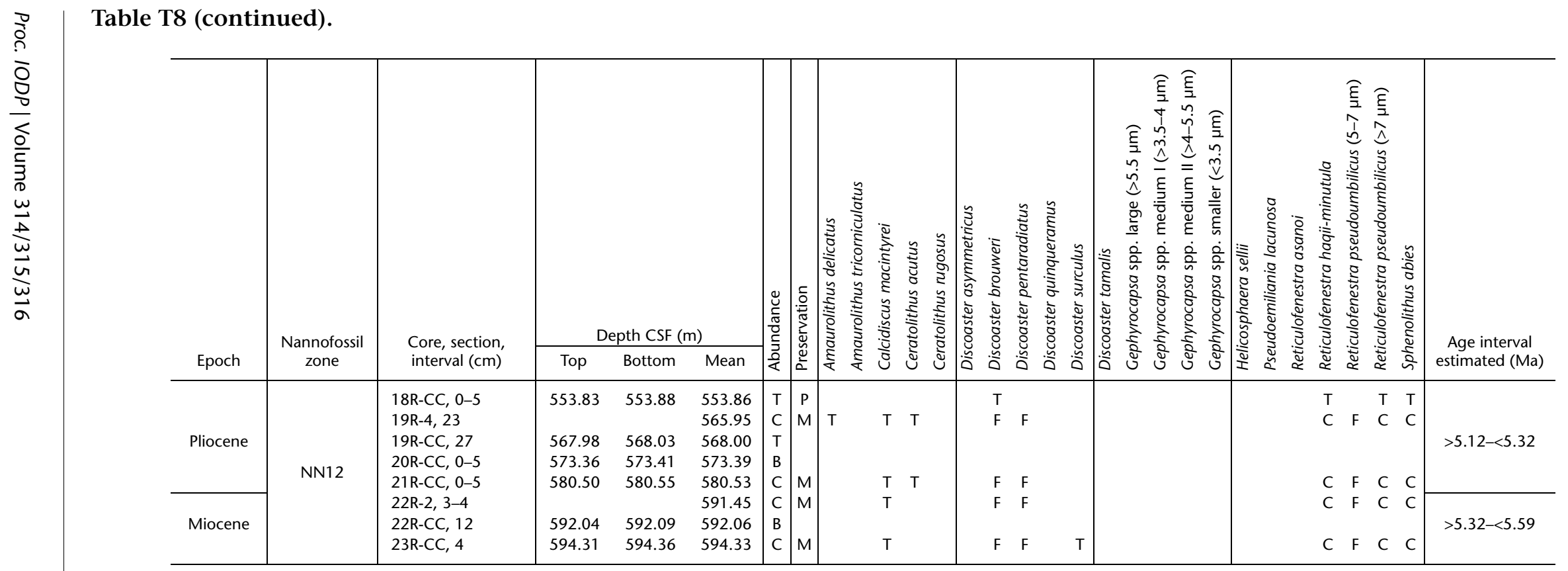

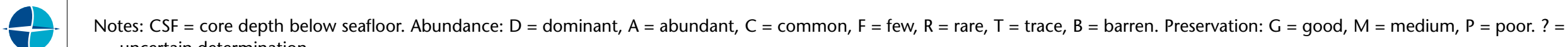
uncertain determination. 
Table T9. Recognized nannofossil events, Holes C0006E and C0006F. (See table notes.)

\begin{tabular}{|c|c|c|c|c|c|c|c|}
\hline \multirow[b]{2}{*}{$\begin{array}{l}\text { Nannofossil } \\
\text { zone }\end{array}$} & \multirow[b]{2}{*}{$\begin{array}{l}\text { Age } \\
(\mathrm{Ma})\end{array}$} & \multirow[b]{2}{*}{ Nannofossil event } & \multicolumn{2}{|l|}{ Top } & \multicolumn{2}{|c|}{ Bottom } & \multirow{2}{*}{$\begin{array}{r}\text { Mean } \\
\text { depth } \\
\text { CSF }(m)\end{array}$} \\
\hline & & & $\begin{array}{l}\text { Core, section, } \\
\text { interval }(\mathrm{cm})\end{array}$ & $\begin{array}{l}\text { Depth } \\
\operatorname{CSF}(\mathrm{m})\end{array}$ & $\begin{array}{l}\text { Core, section, } \\
\text { interval }(\mathrm{cm})\end{array}$ & $\begin{array}{l}\text { Depth } \\
\operatorname{CSF}(\mathrm{m})\end{array}$ & \\
\hline & & & 316-C0006E- & & 316-C0006E- & & \\
\hline NN21 & 0.063 & X Gephyrocapsa spp. (>3.5 $\mu \mathrm{m})$ Emiliania huxleyi & $1 \mathrm{H}-1,1$ & 0.01 & $1 \mathrm{H}-\mathrm{CC}, 0-5$ & 5.16 & 2.59 \\
\hline NN20 & 0.291 & FO Emiliania huxleyi & $2 \mathrm{H}-1,34$ & 5.19 & $2 \mathrm{H}-\mathrm{CC}, 10-15$ & 15.22 & 10.21 \\
\hline \multirow[t]{3}{*}{ NN19 } & 0.436 & LO Pseudoemiliania lacunosa & $3 \mathrm{H}-2,112$ & 17.22 & $3 \mathrm{H}-4,79$ & 18.31 & 17.76 \\
\hline & 0.9 & LCO Reticulofenestra asanoi & $10 \mathrm{H}-\mathrm{CC}, 0-5$ & 64.54 & $11 \mathrm{H}-\mathrm{CC}, 0-5$ & 71.35 & 67.94 \\
\hline & 1.078 & FO Reticulofenestra asanoi & $15 X-C C, 0-5$ & 85.52 & $16 \mathrm{X}-\mathrm{CC}, 0-5$ & 90.73 & 88.12 \\
\hline \multirow{5}{*}{$\begin{array}{l}\text { Reversed part } \\
\text { of NN19 }\end{array}$} & 1.24 & LO Gephyrocapsa spp. large (>5.5 $\mu \mathrm{m})$ & $19 X-C C, 0-5$ & 120.91 & $20 X-4,100$ & 130.59 & 125.75 \\
\hline & 1.6 & LO Calcidiscus macintyrei $(\geq 11 \mu \mathrm{m})$ & $20 \mathrm{X}-\mathrm{CC}, 0-5$ & 133.20 & $21 X-5,2$ & 139.13 & 136.16 \\
\hline & 1.617 & FO Gephyrocapsa spp. large (>5.5 $\mu \mathrm{m})$ & $23 X-C C, 15-20$ & 162.41 & $24 X-1,96$ & 164.29 & 163.35 \\
\hline & 0.9 & LCO Reticulofenestra asanoi & $23 X-C C, 15-20$ & 162.41 & $24 X-1,96$ & 164.29 & 163.35 \\
\hline & 1.04 & RE Gephyrocapsa spp. $(4 \mu \mathrm{m})$ & $24 X-1,96$ & 164.29 & $24 \mathrm{X}-\mathrm{CC}, 0-5$ & 164.51 & 164.40 \\
\hline \multirow[t]{2}{*}{ NN19 } & 0.9 & LCO Reticulofenestra asanoi & $26 \mathrm{X}-3,15-20$ & 185.39 & $26 \mathrm{X}-\mathrm{CC}, 32-37$ & 192.45 & 188.92 \\
\hline & 1.04 & RE Gephyrocapsa spp. (4 $\mu \mathrm{m})$ & $47 X-C C, 4-9$ & 391.40 & $48 \mathrm{X}-\mathrm{CC}, 0-5$ & 400.86 & 396.13 \\
\hline \multirow{4}{*}{ NN19 } & & & 316-C0006F- & & 316-C0006F- & & \\
\hline & 1.04 & RE Gephyrocapsa spp. $(4 \mu \mathrm{m})$ & $1 \mathrm{R}-\mathrm{CC}, 0-5$ & 396.90 & $2 \mathrm{R}-1,76$ & 405.26 & 401.08 \\
\hline & 1.078 & FO Reticulofenestra asanoi & $5 \mathrm{R}-\mathrm{CC}, 0-5$ & 434.71 & $6 \mathrm{R}-2,9$ & 439.50 & 437.11 \\
\hline & 1.24 & LO Gephyrocapsa spp. large $(>5.5 \mu \mathrm{m})$ & $6 \mathrm{R}-2,9$ & 439.50 & $6 \mathrm{R}-\mathrm{CC}, 0-5$ & 439.73 & 439.61 \\
\hline \multirow{6}{*}{ NN16 } & 1.46 & FCO Gephyrocapsa spp. large $(>5.5 \mu \mathrm{m})$ & 7R-CC, $0-5$ & 449.70 & $8 \mathrm{R}-\mathrm{CC}, 0-5$ & 459.01 & 454.35 \\
\hline & 2.06 & LO Discoaster brouweri & $7 \mathrm{R}-\mathrm{CC}, 0-5$ & 449.70 & $8 \mathrm{R}-\mathrm{CC}, 0-5$ & 459.01 & 454.35 \\
\hline & 2.512 & LO Discoaster pentaradiatus & $7 \mathrm{R}-\mathrm{CC}, 0-5$ & 449.70 & $8 \mathrm{R}-\mathrm{CC}, 0-5$ & 459.01 & 454.35 \\
\hline & 2.52 & LO Discoaster surculus & $7 \mathrm{R}-\mathrm{CC}, 0-5$ & 449.70 & $8 \mathrm{R}-\mathrm{CC}, 0-5$ & 459.01 & 454.35 \\
\hline & 2.87 & LO Discoaster tamalis & $7 \mathrm{R}-\mathrm{CC}, 0-5$ & 449.70 & $8 \mathrm{R}-\mathrm{CC}, 0-5$ & 459.01 & 454.35 \\
\hline & 3.65 & LO Sphenolithus spp. & 10R-1, 24 & 476.24 & $10 \mathrm{R}-1,98$ & 476.98 & 476.61 \\
\hline \multirow{2}{*}{ NN13-NN15 } & 3.79 & LO Reticulofenestra pseudoumbilicus ( $>7 \mu \mathrm{m})$ & $11 \mathrm{R}-1,38$ & 485.88 & $11 \mathrm{R}-2,65$ & 487.67 & 486.78 \\
\hline & 5.12 & FO Ceratolithus rugosus & 13R-1, 91-92 & 505.42 & 13R-CC, 31 & 507.51 & 506.46 \\
\hline NN12 & 5.32 & FO Ceratolithus acutus & $21 \mathrm{R}-\mathrm{CC}, 0-5$ & 580.53 & $22 \mathrm{R}-2,3-4$ & 591.45 & 585.99 \\
\hline
\end{tabular}

Notes: $\mathrm{CSF}=$ core depth below seafloor. $\mathrm{X}=$ crossover in abundance, $\mathrm{FO}=$ first occurrence, $\mathrm{LO}=$ last occurrence, $\mathrm{LCO}=$ last consistent occurrence, $\mathrm{RE}=$ reentrance, $\mathrm{FCO}=$ first consistent occurrence. 
Table T10. Corrected geochemistry results from interstitial waters, Site C0006. (See table notes.) (Continued on next page.)

\begin{tabular}{|c|c|c|c|c|c|c|c|c|c|c|c|c|c|c|c|c|c|}
\hline \multirow{2}{*}{$\begin{array}{l}\text { Core, } \\
\text { section }\end{array}$} & \multicolumn{3}{|c|}{ Depth CSF $(m)$} & \multirow[b]{2}{*}{$\mathrm{pH}$} & \multirow{2}{*}{$\begin{array}{l}\text { Alkalinity } \\
(\mathrm{mM})\end{array}$} & \multirow{2}{*}{$\begin{array}{l}\text { Refractive } \\
\text { index }\end{array}$} & \multirow[b]{2}{*}{ Salinity } & \multirow{2}{*}{$\begin{array}{c}\text { Chlorinity } \\
(\mathrm{mM})\end{array}$} & \multirow{2}{*}{$\begin{array}{c}\mathrm{Cl} \\
(\mathrm{mM})\end{array}$} & \multirow{2}{*}{$\begin{array}{c}\mathrm{Br} \\
(\mathrm{mM})\end{array}$} & \multirow{2}{*}{$\begin{array}{l}\mathrm{SO}_{4} \\
(\mathrm{mM})\end{array}$} & \multirow{2}{*}{$\begin{array}{c}\mathrm{Na} \\
(\mathrm{mM})\end{array}$} & \multirow{2}{*}{$\begin{array}{c}\mathrm{K} \\
(\mathrm{mM})\end{array}$} & \multirow{2}{*}{$\begin{array}{c}\mathrm{Mg} \\
(\mathrm{mM})\end{array}$} & \multirow{2}{*}{$\begin{array}{c}\mathrm{Ca} \\
(\mathrm{mM})\end{array}$} & \multirow{2}{*}{$\begin{array}{l}\mathrm{PO}_{4} \\
(\mu \mathrm{M})\end{array}$} & \\
\hline & Top & Bottom & Average & & & & & & & & & & & & & & $(\mu \mathrm{M})$ \\
\hline Seawater & NA & NA & NA & 7.8 & 2.69 & 1.33635 & 35.00 & 552 & 552 & 0.83 & 29.10 & 479 & 9.5 & 52.39 & 9.90 & 3 & 0 \\
\hline $316-\mathrm{C} 000$ & & & & & & & & & & & & & & & & & \\
\hline $1 \mathrm{H}-2$ & 1.27 & 1.48 & 1.37 & 8.0 & 20.13 & 1.33900 & 33.11 & 559 & 558 & 0.88 & 0.00 & 507 & 7.8 & 27.47 & 2.86 & 82 & 2791 \\
\hline $1 \mathrm{H}-6$ & 5.97 & 6.19 & 6.08 & 7.8 & 18.93 & 1.33909 & 33.61 & 563 & - & - & - & - & 9.9 & 33.98 & 3.81 & 90 & 3547 \\
\hline 316-C000 & & & & & & & & & & & & & & & & & \\
\hline $1 \mathrm{H}-2$ & 1.21 & 1.43 & 1.32 & 8.3 & 17.05 & 1.33914 & 33.89 & 558 & 558 & 0.86 & 1.66 & 468 & 11.8 & 42.70 & 5.98 & 42 & 1001 \\
\hline $1 \mathrm{H}-5$ & 4.04 & 4.26 & 4.15 & 8.0 & 20.99 & 1.33895 & 32.83 & 558 & 558 & 0.88 & 0.00 & 489 & 10.2 & 34.81 & 3.67 & 68 & 2459 \\
\hline $316-\mathrm{C} 000$ & & & & & & & & & & & & & & & & & \\
\hline $1 \mathrm{H}-2$ & 1.21 & 1.43 & 1.32 & 8.0 & 7.08 & 1.33923 & 34.39 & 563 & 562 & 0.86 & 25.19 & 495 & 11.8 & 47.49 & 8.76 & 11 & 268 \\
\hline $1 \mathrm{H}-5$ & 4.24 & 4.47 & 4.36 & 8.2 & 21.79 & 1.33912 & 33.78 & 559 & 559 & 0.86 & 4.46 & 485 & 11.7 & 41.18 & 4.90 & 32 & 1039 \\
\hline $2 \mathrm{H}-3$ & 7.79 & 8.02 & 7.91 & 8.2 & 25.78 & 1.33912 & 33.78 & 562 & 561 & 0.85 & 2.14 & 484 & 12.0 & 42.08 & 5.11 & 45 & 1379 \\
\hline $2 \mathrm{H}-7$ & 12.09 & 12.33 & 12.21 & 8.0 & 21.49 & 1.33900 & 33.11 & 559 & 558 & 0.90 & 0.00 & 482 & 11.3 & 38.10 & 4.02 & 64 & 2575 \\
\hline $3 \mathrm{H}-3$ & 17.29 & 17.52 & 17.40 & 7.8 & 18.96 & 1.33896 & 32.89 & 560 & 559 & 0.91 & 0.00 & 489 & 10.4 & 33.83 & 3.97 & 89 & 3694 \\
\hline $3 \mathrm{H}-7$ & 21.66 & 21.89 & 21.77 & 7.8 & 18.78 & 1.33892 & 32.67 & 563 & 562 & 0.92 & 0.00 & 490 & 9.6 & 34.09 & 4.57 & 57 & 4303 \\
\hline $4 \mathrm{H}-5$ & 29.92 & 30.16 & 30.04 & 7.7 & 19.23 & 1.33901 & 33.17 & 564 & 563 & 0.96 & 0.00 & 491 & 9.7 & 33.86 & 4.89 & 68 & 4751 \\
\hline $5 \mathrm{H}-3$ & 35.84 & 36.06 & 35.95 & 7.7 & 19.71 & 1.33901 & 33.17 & 564 & 563 & 0.96 & 0.00 & 491 & 8.9 & 33.85 & 5.24 & 69 & 4820 \\
\hline $7 \mathrm{H}-4$ & 42.92 & 43.16 & 43.04 & 7.8 & 20.48 & 1.33903 & 33.28 & 568 & 567 & 0.99 & 0.00 & 493 & 8.8 & 34.37 & 5.88 & 60 & 5194 \\
\hline $8 \mathrm{H}-4$ & 51.79 & 52.03 & 51.91 & 7.8 & 19.50 & 1.33907 & 33.50 & 565 & 564 & 0.96 & 0.00 & 493 & 9.1 & 32.79 & 5.84 & 34 & 5136 \\
\hline $9 \mathrm{H}-5$ & 62.41 & 62.64 & 62.53 & 7.7 & 19.24 & 1.33907 & 33.50 & 569 & 568 & 1.06 & 0.00 & 495 & 8.7 & 33.24 & 6.15 & 39 & 5285 \\
\hline $10 \mathrm{H}-8$ & 64.51 & 64.67 & 64.59 & 7.8 & 19.37 & 1.33937 & 33.47 & 568 & 567 & 0.96 & 0.00 & 497 & 9.0 & 31.86 & 5.99 & 26 & 5841 \\
\hline $11 \mathrm{H}-4$ & 67.70 & 67.91 & 67.81 & 7.7 & 19.36 & 1.33909 & 33.61 & 569 & 568 & 1.01 & 0.00 & 495 & 8.3 & 33.56 & 6.42 & 44 & 5120 \\
\hline $12 \mathrm{H}-6$ & 76.31 & 76.52 & 76.41 & 7.7 & 17.11 & 1.33881 & 31.21 & 527 & 526 & 0.92 & 0.00 & 463 & 7.8 & 28.74 & 5.52 & 16 & 5222 \\
\hline $15 X-4$ & 81.76 & 81.97 & 81.87 & 7.8 & 17.79 & 1.33915 & 33.52 & 568 & 567 & 1.02 & 0.00 & 497 & 8.8 & 30.80 & 6.21 & 13 & 5578 \\
\hline $16 X-2$ & 90.11 & 90.34 & 90.23 & 7.8 & 17.57 & 1.33919 & 33.56 & 569 & 568 & 0.99 & 0.00 & 497 & 8.4 & 30.98 & 6.24 & 12 & 5656 \\
\hline $17 X-3$ & 100.30 & 100.55 & 100.43 & 7.8 & 16.56 & 1.33940 & 33.66 & 572 & 571 & 0.98 & 0.00 & 503 & 8.1 & 29.29 & 6.19 & 5 & 6042 \\
\hline $19 X-5$ & 119.76 & 120.08 & 119.92 & 7.8 & 16.28 & 1.33908 & 33.56 & 566 & 565 & 1.02 & 0.00 & 496 & 7.7 & 29.27 & 7.04 & 17 & 5458 \\
\hline $20 X-7$ & 132.85 & 133.18 & 133.01 & 7.8 & 14.75 & 1.33937 & 33.47 & 567 & 566 & 1.02 & 0.00 & 501 & 8.7 & 26.02 & 6.70 & 5 & 6098 \\
\hline $21 X-3$ & 137.38 & 137.70 & 137.54 & 7.8 & 14.28 & 1.33907 & 33.19 & 562 & 561 & 1.00 & 0.00 & 493 & 7.6 & 27.57 & 7.03 & 7 & 5687 \\
\hline $22 X-3$ & 146.83 & 147.18 & 147.00 & 7.9 & 13.96 & 1.33902 & 33.22 & 565 & 564 & 1.03 & 0.00 & 495 & 7.8 & 27.84 & 7.35 & 2 & 5745 \\
\hline $23 X-4$ & 157.74 & 158.08 & 157.91 & 7.8 & 13.66 & 1.33907 & 33.13 & 568 & 567 & 1.02 & 0.00 & 503 & 6.9 & 25.50 & 7.30 & 9 & 5775 \\
\hline $25 X-7$ & 180.79 & 181.13 & 180.96 & 7.9 & 13.25 & 1.33911 & 33.29 & 566 & 565 & 1.02 & 0.00 & 500 & 8.0 & 24.24 & 8.66 & 11 & 5514 \\
\hline $26 X-4$ & 186.65 & 186.96 & 186.80 & 7.7 & 12.41 & 1.33901 & 32.45 & 565 & 564 & 1.03 & 0.00 & 503 & 7.1 & 22.05 & 8.68 & 9 & 5758 \\
\hline $27 X-5$ & 197.49 & 197.87 & 197.68 & 7.8 & 11.34 & 1.33898 & 33.00 & 567 & 566 & 1.02 & 0.00 & 498 & 7.2 & 24.64 & 9.32 & 6 & 5387 \\
\hline $28 X-3$ & 203.81 & 204.17 & 203.99 & 7.9 & 11.64 & 1.33893 & 32.72 & 561 & 560 & 1.03 & 0.00 & 501 & 7.3 & 20.74 & 8.86 & 3 & 5010 \\
\hline $29 X-7$ & 219.04 & 219.38 & 219.21 & 7.7 & 10.32 & 1.33896 & 32.89 & 564 & 563 & 0.98 & 0.00 & 503 & 7.2 & 20.69 & 8.97 & 7 & 4378 \\
\hline $30 X-3$ & 223.16 & 223.54 & 223.35 & 7.7 & 10.39 & 1.33899 & 32.67 & 556 & 555 & 1.00 & 0.00 & 497 & 7.0 & 19.37 & 9.01 & 4 & 4984 \\
\hline $31 X-3$ & 232.32 & 232.69 & 232.50 & 7.6 & 8.24 & 1.33922 & 32.68 & 565 & 564 & 0.98 & 0.00 & 508 & 7.1 & 17.56 & 8.94 & 4 & 5273 \\
\hline $32 X-4$ & 243.21 & 243.59 & 243.40 & 7.6 & 10.12 & 1.33889 & 32.50 & 560 & 559 & 0.99 & 0.00 & 502 & 6.9 & 19.41 & 8.79 & 3 & 4700 \\
\hline $34 X-5$ & 263.62 & 264.00 & 263.81 & 7.5 & 10.57 & 1.33931 & 32.60 & 55 & 558 & 0.98 & 0.00 & 504 & 6.6 & 16.53 & 9.80 & 3 & 5228 \\
\hline $35 X-2$ & 268.69 & 269.06 & 268.87 & 7.5 & 10.51 & 1.33930 & 32.61 & 559 & 558 & 0.99 & 0.00 & 504 & 6.3 & 16.73 & 10.18 & 3 & 5334 \\
\hline $36 X-4$ & 281.56 & 281.92 & 281.74 & 7.7 & 9.97 & 1.33907 & 32.18 & 543 & 542 & 0.96 & 0.00 & 490 & 6.5 & 16.25 & 9.67 & 3 & 4825 \\
\hline $37 X-5$ & 292.12 & 292.49 & 292.30 & 8.0 & 10.06 & 1.33889 & 31.96 & 534 & 533 & 0.96 & 0.00 & 481 & 6.8 & 16.33 & 9.44 & 1 & 4642 \\
\hline $38 X-2$ & 296.70 & 296.91 & 296.80 & - & - & 1.33905 & 32.27 & 553 & 552 & 0.97 & 0.00 & 491 & 6.8 & 15.68 & 9.61 & 1 & 4787 \\
\hline $39 X-4$ & 309.69 & 310.07 & 309.88 & 7.7 & 9.09 & 1.33933 & 32.22 & 550 & 549 & 0.97 & 0.00 & 500 & 6.6 & 13.70 & 9.78 & 4 & 5312 \\
\hline $40 X-7$ & 322.01 & 322.41 & 322.21 & 7.8 & 9.74 & 1.33909 & 32.38 & 550 & 549 & 0.97 & 0.00 & 501 & 5.9 & 14.93 & 9.68 & 3 & 4308 \\
\hline $41 X-4$ & 328.83 & 329.21 & 329.02 & 7.9 & 9.33 & 1.33882 & 32.11 & 552 & 551 & 0.95 & 0.00 & 495 & 6.5 & 17.68 & 9.96 & 3 & 3819 \\
\hline $42 X-5$ & 339.58 & 339.99 & 339.78 & 7.6 & 8.94 & 1.33930 & 32.17 & 552 & 551 & 0.94 & 0.00 & 501 & 6.3 & 13.92 & 10.55 & 0 & 4838 \\
\hline $43 X-5$ & 349.11 & 349.49 & 349.30 & 7.7 & 8.54 & 1.33906 & 32.12 & 551 & 550 & 0.96 & 0.00 & 496 & 6.7 & 15.44 & 10.78 & 1 & 4237 \\
\hline $44 X-5$ & 358.99 & 359.37 & 359.18 & 7.7 & 8.79 & 1.33920 & 31.90 & 547 & 546 & 0.94 & 0.00 & 497 & 6.5 & 13.06 & 10.90 & 0 & 4234 \\
\hline
\end{tabular}


Table T10 (continued).

\begin{tabular}{|c|c|c|c|c|c|c|c|c|c|c|c|c|c|c|c|c|c|}
\hline \multirow{2}{*}{$\begin{array}{l}\text { Core, } \\
\text { section }\end{array}$} & \multicolumn{3}{|c|}{ Depth CSF (m) } & \multirow[b]{2}{*}{$\mathrm{pH}$} & \multirow{2}{*}{$\begin{array}{l}\text { Alkalinity } \\
(\mathrm{mM})\end{array}$} & \multirow{2}{*}{$\begin{array}{l}\text { Refractive } \\
\text { index }\end{array}$} & \multirow[b]{2}{*}{ Salinity } & \multirow{2}{*}{$\begin{array}{l}\text { Chlorinity } \\
(\mathrm{mM})\end{array}$} & \multirow{2}{*}{$\begin{array}{c}\mathrm{Cl} \\
(\mathrm{mM})\end{array}$} & \multirow{2}{*}{$\begin{array}{c}\mathrm{Br} \\
(\mathrm{mM})\end{array}$} & \multirow{2}{*}{$\begin{array}{l}\mathrm{SO}_{4} \\
(\mathrm{mM})\end{array}$} & \multirow{2}{*}{$\begin{array}{c}\mathrm{Na} \\
(\mathrm{mM})\end{array}$} & \multirow{2}{*}{$\begin{array}{c}\mathrm{K} \\
(\mathrm{mM})\end{array}$} & \multirow{2}{*}{$\begin{array}{c}\mathrm{Mg} \\
(\mathrm{mM})\end{array}$} & \multirow{2}{*}{$\begin{array}{c}\mathrm{Ca} \\
(\mathrm{mM})\end{array}$} & \multirow{2}{*}{$\begin{array}{c}\mathrm{PO}_{4} \\
(\mu \mathrm{M})\end{array}$} & \multirow{2}{*}{$\begin{array}{l}\mathrm{NH}_{4} \\
(\mu \mathrm{M})\end{array}$} \\
\hline & Top & Bottom & Average & & & & & & & & & & & & & & \\
\hline $45 X-4$ & 366.66 & 367.05 & 366.86 & 7.5 & 7.80 & 1.33883 & 32.17 & 550 & 549 & 0.96 & 0.00 & 492 & 6.6 & 16.88 & 10.78 & 1 & 3427 \\
\hline $46 X-5$ & 377.60 & 377.99 & 377.80 & 8.2 & 6.26 & 1.33882 & 32.11 & 543 & 542 & 0.96 & 0.00 & 488 & 6.8 & 15.10 & 10.11 & 3 & 3595 \\
\hline $47 X-5$ & 386.72 & 387.10 & 386.91 & 7.9 & 7.08 & 1.33889 & 32.50 & 549 & 548 & - & 0.00 & 485 & 6.8 & 18.71 & 11.46 & 1 & 3224 \\
\hline $48 X-5$ & 396.98 & 397.40 & 397.19 & 8.2 & 5.76 & 1.33887 & 31.92 & 542 & 541 & 0.93 & 0.00 & 486 & 6.6 & 15.48 & 10.58 & 1 & 3238 \\
\hline $49 X-4$ & 404.68 & 405.09 & 404.89 & 8.4 & 6.37 & 1.33877 & 31.83 & 544 & 543 & 0.94 & 0.00 & 488 & 7.5 & 14.89 & 11.06 & 0 & 2985 \\
\hline \multicolumn{18}{|c|}{ 316-C0006F- } \\
\hline $2 \mathrm{R}-2$ & 405.52 & 405.91 & 405.72 & 8.2 & 7.12 & 1.33876 & 31.78 & 553 & 552 & 0.95 & 0.00 & 498 & 5.6 & 15.19 & 11.29 & 0 & 2385 \\
\hline $3 R-1$ & 414.00 & 414.39 & 414.20 & 8.1 & 5.82 & 1.33872 & 31.56 & 545 & 544 & 0.94 & 0.00 & 490 & 5.9 & 15.16 & 10.95 & 3 & 2234 \\
\hline $4 \mathrm{R}-2$ & 424.91 & 425.27 & 425.09 & 8.1 & 6.18 & 1.33896 & 32.16 & 546 & 545 & 0.92 & 0.00 & 489 & 6.5 & 15.64 & 11.18 & 4 & 2680 \\
\hline $5 \mathrm{R}-1$ & 434.25 & 434.50 & 434.37 & 7.8 & 6.12 & 1.33874 & 31.67 & 545 & 544 & 0.93 & 0.00 & 493 & 6.1 & 14.45 & 10.45 & 4 & 2252 \\
\hline 6R-1 & 439.08 & 439.41 & 439.25 & 7.9 & 4.26 & 1.33888 & 31.76 & 551 & 550 & 0.90 & 0.00 & 493 & 6.7 & 16.43 & 10.06 & 0 & 1860 \\
\hline 7R-1 & 448.40 & 448.66 & 448.53 & 7.5 & 6.34 & 1.33869 & 31.39 & 544 & 543 & 0.94 & 0.00 & 493 & 5.7 & 13.71 & 10.75 & 0 & 1634 \\
\hline $8 \mathrm{R}-1$ & 458.03 & 458.41 & 458.22 & 7.6 & 6.88 & 1.33869 & 31.39 & 542 & 541 & 0.89 & 0.00 & 490 & 5.1 & 14.00 & 12.02 & 3 & 1607 \\
\hline 9R-1 & 467.04 & 467.45 & 467.24 & 7.6 & 8.17 & 1.33876 & 31.78 & 545 & 544 & 0.91 & 0.00 & 492 & 5.6 & 14.62 & 12.23 & 4 & 1563 \\
\hline 10R-1 & 477.25 & 477.50 & 477.37 & 7.8 & 7.75 & 1.33875 & 31.72 & 544 & 543 & 0.92 & 0.00 & 493 & 5.8 & 12.83 & 12.78 & 4 & 1256 \\
\hline 11R-1a & 485.50 & 485.64 & 485.57 & 8.1 & 6.16 & 1.33896 & 32.09 & 542 & 541 & 0.88 & 0.00 & 482 & 6.9 & 16.79 & 12.24 & 4 & 908 \\
\hline $11 \mathrm{R}-1 \mathrm{~b}$ & 485.88 & 486.20 & 486.04 & 0.0 & - & 1.33869 & 31.39 & - & - & - & 0.00 & - & 6.6 & 12.78 & 12.47 & - & - \\
\hline $12 \mathrm{R}-2$ & 496.44 & 496.84 & 496.64 & 8.1 & 6.91 & 1.33873 & 31.61 & 544 & 543 & 0.91 & 0.00 & 492 & 5.7 & 12.37 & 13.32 & 5 & 1271 \\
\hline $13 \mathrm{R}-2$ & 505.90 & 506.30 & 506.10 & 8.2 & 4.70 & 1.33871 & 31.07 & 541 & 540 & 0.89 & 0.00 & 481 & 6.1 & 14.92 & 13.56 & 3 & 1193 \\
\hline $14 \mathrm{R}-2$ & 516.58 & 517.02 & 516.80 & 8.0 & 6.03 & 1.33887 & 31.98 & 542 & 541 & 0.90 & 0.00 & 488 & 6.1 & 12.66 & 13.85 & 1 & 1045 \\
\hline $15 \mathrm{R}-1$ & 523.50 & 523.90 & 523.70 & 8.0 & 5.08 & 1.33873 & 31.18 & 542 & 541 & 0.89 & 0.00 & 485 & 4.2 & 13.13 & 15.45 & 4 & 1030 \\
\hline 16R-1 & 534.00 & 534.42 & 534.21 & NC & NC & NC & NC & NC & NC & NC & NC & NC & NC & NC & NC & NC & $N C$ \\
\hline 17R-1 & 542.65 & 543.06 & 542.86 & NC & NC & NC & NC & NC & NC & NC & NC & NC & NC & NC & NC & NC & NC \\
\hline $18 \mathrm{R}-1$ & 553.11 & 553.50 & 553.31 & NC & NC & NC & NC & NC & NC & NC & NC & NC & NC & NC & NC & NC & $N C$ \\
\hline $19 \mathrm{R}-3$ & 565.26 & 565.67 & 565.46 & NC & NC & NC & NC & NC & NC & NC & NC & NC & NC & NC & NC & NC & $N C$ \\
\hline 20R-1 & 571.18 & 571.49 & 571.34 & NC & NC & NC & NC & NC & NC & NC & NC & NC & NC & NC & NC & NC & NC \\
\hline 22R-1 & 590.00 & 590.42 & 590.21 & NC & NC & NC & NC & NC & NC & NC & NC & NC & NC & NC & NC & NC & NC \\
\hline
\end{tabular}

Notes: $\mathrm{CSF}=$ core depth below seafloor. Na calculated from charge balance. $-=$ not analyzed, NC = not corrected (values are in Table T12 and are plotted in the figures). 
Table T11. Corrected concentrations of minor elements in interstitial waters, Site C0006. (See table notes.) (Continued on next page.)

\begin{tabular}{|c|c|c|c|c|c|c|c|c|c|c|}
\hline \multirow{2}{*}{$\begin{array}{c}\text { Core, } \\
\text { section }\end{array}$} & \multicolumn{3}{|c|}{ Depth CSF (m) } & \multicolumn{7}{|c|}{ Minor elements $(\mu \mathrm{m})$} \\
\hline & Top & Bottom & Average & $\mathrm{Li}$ & B & $\mathrm{Sr}$ & $\mathrm{Ba}$ & $\mathrm{Si}$ & $\mathrm{Fe}$ & $\mathrm{Mn}$ \\
\hline Seawater & NA & NA & NA & 25.8 & 395 & 79 & 0.0 & 3 & 0.23 & 0.26 \\
\hline \multicolumn{11}{|c|}{ 316-C0006C- } \\
\hline $1 \mathrm{H}-2$ & 1.27 & 1.48 & 1.37 & 11.7 & 443 & 66 & 10.3 & 744 & 0.52 & 0.57 \\
\hline $1 \mathrm{H}-6$ & 5.97 & 6.19 & 6.08 & 10.5 & 442 & 68 & 10.2 & 642 & 0.66 & 1.50 \\
\hline \multicolumn{11}{|c|}{ 316-C0006D- } \\
\hline $1 \mathrm{H}-2$ & 1.21 & 1.43 & 1.32 & 20.5 & 494 & 74 & 2.4 & 613 & 0.27 & 0.59 \\
\hline $1 \mathrm{H}-5$ & 4.04 & 4.26 & 4.15 & 14.5 & 461 & 70 & 10.8 & 764 & 0.28 & 0.54 \\
\hline \multicolumn{11}{|c|}{ 316-C0006E- } \\
\hline $1 \mathrm{H}-2$ & 1.21 & 1.43 & 1.32 & 31.8 & 556 & 80 & 0.6 & 437 & 0.72 & 6.91 \\
\hline $1 \mathrm{H}-5$ & 4.24 & 4.47 & 4.36 & 23.9 & 514 & 74 & 3.6 & 581 & 0.68 & 0.64 \\
\hline $2 \mathrm{H}-3$ & 7.79 & 8.02 & 7.91 & 19.9 & 554 & 76 & 7.1 & 646 & 0.48 & 0.68 \\
\hline $2 \mathrm{H}-7$ & 12.09 & 12.33 & 12.21 & 15.1 & 494 & 75 & 12.7 & 695 & 0.80 & 0.74 \\
\hline $3 \mathrm{H}-3$ & 17.29 & 17.52 & 17.40 & 13.2 & 456 & 77 & 11.7 & 563 & 4.88 & 1.30 \\
\hline $3 \mathrm{H}-7$ & 21.66 & 21.89 & 21.77 & 15.7 & 484 & 80 & 10.9 & 595 & 39.96 & 3.29 \\
\hline $4 \mathrm{H}-5$ & 29.92 & 30.16 & 30.04 & 12.6 & 433 & 79 & 10.3 & 524 & 2.33 & 4.66 \\
\hline $5 \mathrm{H}-3$ & 35.84 & 36.06 & 35.95 & 11.6 & 419 & 83 & 11.7 & 468 & 5.02 & 4.55 \\
\hline $7 \mathrm{H}-4$ & 42.92 & 43.16 & 43.04 & 13.4 & 409 & 89 & 12.1 & 471 & 1.93 & 4.17 \\
\hline $8 \mathrm{H}-4$ & 51.79 & 52.03 & 51.91 & 14.8 & 437 & 89 & 12.3 & 568 & 8.85 & 5.24 \\
\hline $9 \mathrm{H}-5$ & 62.41 & 62.64 & 62.53 & 14.5 & 413 & 91 & 12.4 & 538 & 6.46 & 7.46 \\
\hline $10 \mathrm{H}-8$ & 64.51 & 64.67 & 64.59 & 13.5 & 446 & 92 & 14.3 & 492 & 14.60 & 16.13 \\
\hline $11 \mathrm{H}-4$ & 67.70 & 67.91 & 67.81 & 13.4 & 416 & 93 & 12.7 & 490 & 28.21 & 7.08 \\
\hline $12 \mathrm{H}-6$ & 76.31 & 76.52 & 76.41 & 7.3 & 404 & 74 & 9.0 & 465 & 23.04 & 5.81 \\
\hline $15 X-4$ & 81.76 & 81.97 & 81.87 & 9.7 & 395 & 79 & 8.9 & 529 & 0.91 & 3.25 \\
\hline $16 X-2$ & 90.11 & 90.34 & 90.23 & 15.0 & 311 & 80 & 10.0 & 462 & 1.88 & 5.48 \\
\hline $17 X-3$ & 100.30 & 100.55 & 100.43 & 12.8 & 370 & 80 & 12.2 & 537 & 1.02 & 4.81 \\
\hline $19 X-5$ & 119.76 & 120.08 & 119.92 & 13.7 & 389 & 81 & 10.4 & 593 & 4.86 & 5.22 \\
\hline $20 X-7$ & 132.85 & 133.18 & 133.01 & 32.9 & 231 & 80 & 12.0 & 369 & 10.76 & 5.10 \\
\hline $21 X-3$ & 137.38 & 137.70 & 137.54 & 12.9 & 248 & 74 & 9.4 & 573 & 0.64 & 3.57 \\
\hline $22 X-3$ & 146.83 & 147.18 & 147.00 & 14.8 & 223 & 76 & 9.6 & 417 & 0.55 & 3.15 \\
\hline $23 X-4$ & 157.74 & 158.08 & 157.91 & 13.3 & 248 & 77 & 9.3 & 675 & 0.78 & 4.11 \\
\hline $25 X-7$ & 180.79 & 181.13 & 180.96 & 28.1 & 233 & 85 & 13.8 & 535 & 1.27 & 5.14 \\
\hline $26 X-4$ & 186.65 & 186.96 & 186.80 & 15.7 & 230 & 79 & 12.4 & 732 & 2.71 & 5.26 \\
\hline $27 X-5$ & 197.49 & 197.87 & 197.68 & 20.2 & 203 & 82 & 12.1 & 471 & 6.65 & 4.94 \\
\hline $28 X-3$ & 203.81 & 204.17 & 203.99 & 15.7 & 177 & 81 & 11.3 & 542 & 50.91 & 8.70 \\
\hline $29 X-7$ & 219.04 & 219.38 & 219.21 & 27.8 & 154 & 87 & 13.2 & 636 & 0.86 & 5.54 \\
\hline $30 X-3$ & 223.16 & 223.54 & 223.35 & 21.8 & 178 & 86 & 13.0 & 675 & 1.05 & 5.61 \\
\hline $31 X-3$ & 232.32 & 232.69 & 232.50 & 21.9 & 174 & 85 & 13.6 & 676 & 0.21 & 5.26 \\
\hline $32 X-4$ & 243.21 & 243.59 & 243.40 & 22.2 & 219 & 85 & 12.3 & 741 & 0.45 & 4.46 \\
\hline $34 X-5$ & 263.62 & 264.00 & 263.81 & 25.5 & 157 & 91 & 14.8 & 649 & 8.07 & 6.35 \\
\hline $35 X-2$ & 268.69 & 269.06 & 268.87 & 18.3 & 142 & 89 & 14.4 & 571 & 2.59 & 8.40 \\
\hline $36 X-4$ & 281.56 & 281.92 & 281.74 & 19.2 & 200 & 81 & 13.5 & 765 & 2.96 & 6.59 \\
\hline $37 X-5$ & 292.12 & 292.49 & 292.30 & 21.2 & 173 & 86 & 13.3 & 653 & 0.77 & 4.32 \\
\hline $38 X-2$ & 296.70 & 296.91 & 296.80 & 22.1 & 191 & 85 & 13.4 & 764 & 0.67 & 4.71 \\
\hline $39 X-4$ & 309.69 & 310.07 & 309.88 & 28.3 & 163 & 89 & 15.4 & 693 & 2.36 & 5.34 \\
\hline $40 X-7$ & 322.01 & 322.41 & 322.21 & 23.7 & 179 & 91 & 13.7 & 830 & 0.50 & 5.86 \\
\hline $41 X-4$ & 328.83 & 329.21 & 329.02 & 26.2 & 141 & 92 & 12.6 & 763 & 2.09 & 4.42 \\
\hline $42 X-5$ & 339.58 & 339.99 & 339.78 & 25.6 & 157 & 97 & 15.1 & 759 & 13.84 & 7.04 \\
\hline $43 X-5$ & 349.11 & 349.49 & 349.30 & 32.0 & 134 & 98 & 14.2 & 450 & 3.42 & 6.55 \\
\hline $44 X-5$ & 358.99 & 359.37 & 359.18 & 29.7 & 174 & 104 & 15.8 & 723 & 0.82 & 7.90 \\
\hline $45 X-4$ & 366.66 & 367.05 & 366.86 & 31.0 & 170 & 102 & 15.4 & 715 & 0.78 & 6.68 \\
\hline $46 X-5$ & 377.60 & 377.99 & 377.80 & 29.8 & 147 & 105 & 19.0 & 385 & 0.59 & 3.39 \\
\hline $47 X-5$ & 386.72 & 387.10 & 386.91 & 34.3 & 162 & 117 & 24.3 & 573 & 0.60 & 6.89 \\
\hline $48 X-5$ & 396.98 & 397.40 & 397.19 & 38.8 & 147 & 115 & 35.7 & 454 & 0.52 & 5.54 \\
\hline $49 X-4$ & 404.68 & 405.09 & 404.89 & 54.6 & 169 & 116 & 25.7 & 328 & 0.43 & 5.49 \\
\hline \multicolumn{11}{|c|}{ 316-C0006F- } \\
\hline $2 \mathrm{R}-2$ & 405.52 & 405.91 & 405.72 & 41.9 & 186 & 124 & 66.6 & 560 & 0.95 & 9.28 \\
\hline $3 R-1$ & 414.00 & 414.39 & 414.20 & 44.5 & 166 & 125 & 93.7 & 764 & 0.18 & 7.97 \\
\hline $4 \mathrm{R}-2$ & 424.91 & 425.27 & 425.09 & 57.0 & 133 & 114 & 25.0 & 544 & 0.13 & 4.13 \\
\hline $5 R-1$ & 434.25 & 434.50 & 434.37 & 64.4 & 166 & 109 & 35.4 & 651 & 0.12 & 5.23 \\
\hline $6 \mathrm{R}-1$ & 439.08 & 439.41 & 439.25 & 71.5 & 170 & 105 & 32.7 & 764 & 0.22 & 3.87 \\
\hline 7R-1 & 448.40 & 448.66 & 448.53 & 80.4 & 155 & 119 & 74.7 & 911 & 0.92 & 4.03 \\
\hline $8 R-1$ & 458.03 & 458.41 & 458.22 & 92.7 & 164 & 117 & 41.8 & 982 & 0.15 & 8.56 \\
\hline 9R-1 & 467.04 & 467.45 & 467.24 & 96.8 & 164 & 107 & 11.9 & 923 & 3.27 & 11.65 \\
\hline $10 \mathrm{R}-1$ & 477.25 & 477.50 & 477.37 & 102.9 & 167 & 114 & 95.0 & 928 & 2.45 & 19.10 \\
\hline 11R-1a & 485.50 & 485.64 & 485.57 & 94.7 & 131 & 96 & 26.1 & 581 & 0.13 & 10.19 \\
\hline
\end{tabular}


Table T11 (continued).

\begin{tabular}{|c|c|c|c|c|c|c|c|c|c|c|}
\hline \multirow{2}{*}{$\begin{array}{l}\text { Core, } \\
\text { section }\end{array}$} & \multicolumn{3}{|c|}{ Depth CSF (m) } & \multicolumn{7}{|c|}{ Minor elements $(\mu \mathrm{m})$} \\
\hline & Top & Bottom & Average & $\mathrm{Li}$ & B & $\mathrm{Sr}$ & $\mathrm{Ba}$ & $\mathrm{Si}$ & $\mathrm{Fe}$ & Mn \\
\hline $11 \mathrm{R}-1 \mathrm{~b}$ & 485.88 & 486.20 & 486.04 & 101.7 & 69 & 104 & 31.4 & 393 & 0.00 & 6.40 \\
\hline $12 \mathrm{R}-2$ & 496.44 & 496.84 & 496.64 & 111.5 & 140 & 107 & 52.5 & 743 & 0.25 & 16.78 \\
\hline $13 R-2$ & 505.90 & 506.30 & 506.10 & 110.6 & 111 & 97 & 27.8 & 576 & 0.11 & 7.16 \\
\hline $14 \mathrm{R}-2$ & 516.58 & 517.02 & 516.80 & 124.1 & 111 & 102 & 42.6 & 470 & 0.00 & 8.39 \\
\hline $15 R-1$ & 523.50 & 523.90 & 523.70 & 119.3 & 118 & 107 & 44.9 & 648 & 0.00 & 21.98 \\
\hline $16 \mathrm{R}-1$ & 534.00 & 534.42 & 534.21 & $\mathrm{NC}$ & NC & NC & NC & NC & NC & NC \\
\hline $17 R-1$ & 542.65 & 543.06 & 542.86 & NC & $N C$ & $\mathrm{NC}$ & $\mathrm{NC}$ & NC & NC & NC \\
\hline $18 \mathrm{R}-1$ & 553.11 & 553.50 & 553.31 & NC & $\mathrm{NC}$ & $\mathrm{NC}$ & $\mathrm{NC}$ & NC & $\mathrm{NC}$ & NC \\
\hline $19 R-3$ & 565.26 & 565.67 & 565.46 & NC & $\mathrm{NC}$ & $\mathrm{NC}$ & $\mathrm{NC}$ & $\mathrm{NC}$ & $\mathrm{NC}$ & $\mathrm{NC}$ \\
\hline 20R-1 & 571.18 & 571.49 & 571.34 & NC & NC & $\mathrm{NC}$ & NC & NC & $\mathrm{NC}$ & NC \\
\hline $22 \mathrm{R}-1$ & 590.00 & 590.42 & 590.21 & NC & $\mathrm{NC}$ & $\mathrm{NC}$ & $\mathrm{NC}$ & NC & NC & $\mathrm{NC}$ \\
\hline
\end{tabular}

Notes: CSF = core depth below seafloor. NA = not applicable, NC = not corrected (see Table T13 for values). 
Table T12. Uncorrected geochemistry results from interstitial waters, Site C0006. (See table notes.) (Continued on next page.)

\begin{tabular}{|c|c|c|c|c|c|c|c|c|c|c|c|c|c|c|c|c|c|}
\hline \multirow{2}{*}{$\begin{array}{l}\text { Core, } \\
\text { section }\end{array}$} & \multicolumn{3}{|c|}{ Depth CSF (m) } & \multirow[b]{2}{*}{$\mathrm{pH}$} & \multirow{2}{*}{$\begin{array}{l}\text { Alkalinity } \\
(\mathrm{mM})\end{array}$} & \multirow{2}{*}{$\begin{array}{l}\text { Refractive } \\
\text { index }\end{array}$} & \multirow[b]{2}{*}{ Salinity } & \multirow{2}{*}{$\begin{array}{c}\text { Chlorinity } \\
(\mathrm{mM})\end{array}$} & \multirow{2}{*}{$\underset{(\mathrm{mM})}{\mathrm{Cl}}$} & \multirow{2}{*}{$\begin{array}{c}\mathrm{Br} \\
(\mathrm{mM})\end{array}$} & \multirow{2}{*}{$\begin{array}{c}\mathrm{SO}_{4} \\
(\mathrm{mM})\end{array}$} & \multirow{2}{*}{$\begin{array}{c}\mathrm{Na} \\
(\mathrm{mM})\end{array}$} & \multirow{2}{*}{$\begin{array}{c}\mathrm{K} \\
(\mathrm{mM})\end{array}$} & \multirow{2}{*}{$\begin{array}{c}\mathrm{Mg} \\
(\mathrm{mM})\end{array}$} & \multirow{2}{*}{$\begin{array}{c}\mathrm{Ca} \\
(\mathrm{mM})\end{array}$} & $\mathrm{PO}_{4}$ & $\mathrm{H}_{4}$ \\
\hline & Top & Bottom & Average & & & & & & & & & & & & & $(\mu \mathrm{m})$ & $(\mu \mathrm{m})$ \\
\hline $316-\mathrm{COO}$ & & & & & & & & & & & & & & & & & \\
\hline $1 \mathrm{H}-2$ & 1.27 & 1.48 & 1.37 & 8.0 & 20.13 & 1.33900 & 33.11 & 559 & 558 & 0.88 & 0.00 & 507 & 7.8 & 27.50 & 2.86 & 82 & 2791 \\
\hline $1 \mathrm{H}-6$ & 5.97 & 6.19 & 6.08 & 7.8 & 18.93 & 1.33909 & 33.61 & 563 & & & & & 9.9 & 34.00 & 3.81 & 90 & 3547 \\
\hline $316-\mathrm{COO}$ & & & & & & & & & & & & & & & & & \\
\hline $1 \mathrm{H}-2$ & 1.21 & 1.43 & 1.32 & 8.3 & 17.05 & 1.33914 & 33.89 & 558 & 558 & 0.86 & 1.66 & 468 & 11.8 & 42.70 & 5.98 & 42 & 1001 \\
\hline $1 \mathrm{H}-5$ & 4.04 & 4.26 & 4.15 & 8.0 & 20.99 & 1.33895 & 32.83 & 558 & 558 & 0.88 & 0.00 & 489 & 10.2 & 34.80 & 3.67 & 68 & 2459 \\
\hline $316-\mathrm{COO}$ & & & & & & & & & & & & & & & & & \\
\hline $1 \mathrm{H}-2$ & 1.21 & 1.43 & 1.32 & 8.0 & 7.08 & 1.33923 & 34.39 & 563 & 562 & 0.86 & 25.19 & 495 & 11.8 & 47.50 & 8.76 & 11 & 268 \\
\hline $1 \mathrm{H}-5$ & 4.24 & 4.47 & 4.36 & 8.2 & 21.79 & 1.33912 & 33.78 & 559 & 559 & 0.86 & 4.46 & 485 & 11.7 & 41.20 & 4.90 & 32 & 1039 \\
\hline $2 \mathrm{H}-3$ & 7.79 & 8.02 & 7.91 & 8.2 & 25.78 & 1.33912 & 33.78 & 562 & 561 & 0.85 & 2.14 & 484 & 12.0 & 42.10 & 5.11 & 45 & 1379 \\
\hline $2 \mathrm{H}-7$ & 12.09 & 12.33 & 12.21 & 8.0 & 21.49 & 1.33900 & 33.11 & 559 & 558 & 0.90 & 0.00 & 482 & 11.3 & 38.10 & 4.02 & 64 & 2575 \\
\hline $3 \mathrm{H}-3$ & 17.29 & 17.52 & 17.40 & 7.8 & 18.96 & 1.33896 & 32.89 & 560 & 559 & 0.91 & 0.00 & 489 & 10.4 & 33.80 & 3.97 & 89 & 3694 \\
\hline $3 \mathrm{H}-7$ & 21.66 & 21.89 & 21.77 & 7.8 & 18.78 & 1.33892 & 32.67 & 563 & 562 & 0.92 & 0.00 & 490 & 9.6 & 34.10 & 4.57 & 57 & 4303 \\
\hline $4 \mathrm{H}-5$ & 29.92 & 30.16 & 30.04 & 7.7 & 19.23 & 1.33901 & 33.17 & 564 & 563 & 0.96 & 0.00 & 491 & 9.7 & 33.90 & 4.89 & 68 & 4751 \\
\hline $5 \mathrm{H}-3$ & 35.84 & 36.06 & 35.95 & 7.7 & 19.71 & 1.33901 & 33.17 & 564 & 563 & 0.96 & 0.00 & 491 & 8.9 & 33.90 & 5.24 & 69 & 4820 \\
\hline $7 \mathrm{H}-4$ & 42.92 & 43.16 & 43.04 & 7.8 & 20.48 & 1.33903 & 33.28 & 568 & 567 & 0.99 & 0.00 & 493 & 8.8 & 34.40 & 5.88 & 60 & 5194 \\
\hline $8 \mathrm{H}-4$ & 51.79 & 52.03 & 51.91 & 7.8 & 19.50 & 1.33907 & 33.50 & 565 & 564 & 0.96 & 0.00 & 493 & 9.1 & 32.80 & 5.84 & 34 & 5136 \\
\hline $9 \mathrm{H}-5$ & 62.41 & 62.64 & 62.53 & 7.7 & 19.24 & 1.33907 & 33.50 & 569 & 568 & 1.06 & 0.00 & 495 & 8.7 & 33.20 & 6.15 & 39 & 5285 \\
\hline $10 \mathrm{H}-8$ & 64.51 & 64.67 & 64.59 & 7.8 & 17.83 & 1.33909 & 33.61 & 567 & 566 & 0.94 & 2.69 & 495 & 9.1 & 33.80 & 6.35 & 24 & 5301 \\
\hline $11 \mathrm{H}-4$ & 67.70 & 67.91 & 67.81 & 7.7 & 19.36 & 1.33909 & 33.61 & 569 & 568 & 1.01 & 0.00 & 495 & 8.3 & 33.60 & 6.42 & 44 & 5120 \\
\hline $12 \mathrm{H}-6$ & 76.31 & 76.52 & 76.41 & 7.7 & 16.42 & 1.33869 & 31.39 & 529 & 528 & 0.91 & 1.40 & 463 & 7.9 & 29.90 & 5.73 & 15 & 4971 \\
\hline $15 X-4$ & 81.76 & 81.97 & 81.87 & 7.8 & 17.42 & 1.33908 & 33.56 & 568 & 567 & 1.02 & 0.71 & 497 & 8.8 & 31.30 & 6.30 & 13 & 5442 \\
\hline $16 X-2$ & 90.11 & 90.34 & 90.23 & 7.8 & 17.07 & 1.33909 & 33.61 & 568 & 567 & 0.98 & 0.98 & 497 & 8.5 & 31.70 & 6.36 & 11 & 5466 \\
\hline $17 X-3$ & 100.30 & 100.55 & 100.43 & 7.8 & 15.29 & 1.33912 & 33.78 & 571 & 570 & 0.97 & 2.66 & 501 & 8.2 & 31.40 & 6.53 & 5 & 5491 \\
\hline $19 X-5$ & 119.76 & 120.08 & 119.92 & 7.8 & 16.28 & 1.33908 & 33.56 & 566 & 56 & 1.02 & 0.00 & 496 & 7.7 & 9.30 & 7.04 & 17 & 5458 \\
\hline $20 X-7$ & 132.85 & 133.18 & 133.01 & 7.8 & 13.63 & 1.33909 & 33.61 & 566 & 565 & 1.00 & 2.70 & 499 & 8.8 & 28.50 & 6.99 & 5 & 5532 \\
\hline $21 X-3$ & 137.38 & 137.70 & 137.54 & 7.8 & 14.07 & 1.33902 & 33.22 & 562 & 561 & 0.99 & 0.52 & 493 & 7.6 & 28.02 & 7.09 & 7 & 5585 \\
\hline $22 X-3$ & 146.83 & 147.18 & 147.00 & 7.9 & 13.96 & 1.33902 & 33.22 & 565 & 564 & 1.03 & 0.00 & 495 & 7.8 & 27.84 & 7.35 & 2 & 5745 \\
\hline $23 X-4$ & 157.74 & 158.08 & 157.91 & 7.8 & 13.42 & 1.33901 & 33.17 & 568 & 567 & 1.01 & 0.62 & 503 & 6.9 & 26.07 & 7.35 & 9 & 5651 \\
\hline $25 X-7$ & 180.79 & 181.13 & 180.96 & 7.9 & 12.99 & 1.33904 & 33.33 & 566 & 565 & 1.02 & 0.72 & 499 & 8.0 & 24.90 & 8.69 & 11 & 5378 \\
\hline $26 \mathrm{X}-4$ & 186.65 & 186.96 & 186.80 & 7.7 & 11.99 & 1.33890 & 32.56 & 565 & 564 & 1.02 & 1.26 & 502 & 7.2 & 23.36 & 8.73 & 9 & 5510 \\
\hline $27 X-5$ & 197.49 & 197.87 & 197.68 & 7.8 & 11.34 & 1.33898 & 33.00 & 567 & 566 & 1.02 & 0.00 & 498 & 7.2 & 24.64 & 9.32 & 6 & 5387 \\
\hline $28 X-3$ & 203.81 & 204.17 & 203.99 & 7.9 & 11.64 & 1.33893 & 32.72 & 561 & 560 & 1.03 & 0.00 & 501 & 7.3 & 20.74 & 8.86 & 3 & 5010 \\
\hline $29 X-7$ & 219.04 & 219.38 & 219.21 & 7.7 & 10.32 & 1.33896 & 32.89 & 564 & 563 & 0.98 & 0.00 & 503 & 7.2 & 20.69 & 8.97 & 7 & 4378 \\
\hline $30 X-3$ & 223.16 & 223.54 & 223.35 & 7.7 & 10.23 & 1.33893 & 32.72 & 556 & 555 & 1.00 & 0.62 & 497 & 7.1 & 20.07 & 9.03 & 4 & 4878 \\
\hline $31 X-3$ & 232.32 & 232.69 & 232.50 & 7.6 & 7.73 & 1.33896 & 32.89 & 564 & 563 & 0.97 & 2.65 & 505 & 7.3 & 20.73 & 9.02 & 4 & 4793 \\
\hline $32 X-4$ & 243.21 & 243.59 & 243.40 & 7.6 & 10.12 & 1.33889 & 32.50 & 560 & 559 & 0.99 & 0.00 & 502 & 6.9 & 19.41 & 8.79 & 3 & 4700 \\
\hline $34 X-5$ & 263.62 & 264.00 & 263.81 & 7.5 & 9.63 & 1.33896 & 32.89 & 558 & 557 & 0.96 & 3.46 & 501 & 7.0 & 20.80 & 9.81 & 3 & 4607 \\
\hline $35 X-2$ & 268.69 & 269.06 & 268.87 & 7.6 & 9.61 & 1.33896 & 32.89 & 558 & 557 & 0.97 & 3.37 & 501 & 6.7 & 20.86 & 10.15 & 3 & 4717 \\
\hline $36 \mathrm{X}-4$ & 281.56 & 281.92 & 281.74 & 7.7 & 9.43 & 1.33887 & 32.39 & 544 & 543 & 0.95 & 2.18 & 489 & 6.7 & 18.96 & 9.69 & 3 & 4463 \\
\hline $37 X-5$ & 292.12 & 292.49 & 292.30 & 8.0 & 9.83 & 1.33881 & 32.06 & 535 & 53 & 0.96 & 0.91 & 481 & 6.9 & 17.46 & 9.45 & 1 & 4497 \\
\hline $38 \mathrm{X}-2$ & 296.70 & 296.91 & 296.80 & - & - & 1.33888 & 32.44 & 553 & 552 & 0.96 & 1.81 & 490 & 6.9 & 17.97 & 9.63 & 1 & 4488 \\
\hline $39 X-4$ & 309.69 & 310.07 & 309.88 & 7.8 & 8.19 & 1.33891 & 32.61 & 550 & 549 & 0.95 & 4.09 & 497 & 7.0 & 19.14 & 9.80 & 4 & 4564 \\
\hline $40 X-7$ & 322.01 & 322.41 & 322.2 & 7.8 & 9.26 & 1.33890 & 32.56 & 551 & 550 & 0.96 & 1.99 & 499 & 6.1 & 17.49 & 9.69 & 3 & 4014 \\
\hline $41 X-4$ & 328.83 & 329.21 & 329.02 & 7.9 & 9.33 & 1.33882 & 32.11 & 552 & 551 & 0.95 & 0.00 & 495 & 6.5 & 17.68 & 9.96 & 3 & 3819 \\
\hline $42 X-5$ & 339.58 & 339.99 & 339.78 & 7.6 & 8.09 & 1.33890 & 32.56 & 552 & 551 & 0.93 & 3.94 & 498 & 6.7 & 19.13 & 10.46 & 0 & 4183 \\
\hline $43 X-5$ & 349.11 & 349.49 & 349.30 & 7.7 & 8.12 & 1.33886 & 32.33 & 551 & 550 & 0.95 & 2.11 & 495 & 6.9 & 18.12 & 10.71 & 1 & 3929 \\
\hline $44 X-5$ & 358.99 & 359.37 & 359.18 & 7.7 & 8.04 & 1.33885 & 32.28 & 548 & 547 & 0.93 & 3.55 & 495 & 6.9 & 17.86 & 10.78 & 0 & 3717 \\
\hline $45 X-4$ & 366.66 & 367.05 & 366.86 & 7.5 & 7.80 & 1.33883 & 32.17 & 550 & 549 & 0.96 & 0.00 & 492 & 6.6 & 16.88 & 10.78 & 1 & 3427 \\
\hline $46 \mathrm{X}-5$ & 377.60 & 377.99 & 377.80 & 8.2 & 6.26 & 1.33882 & 32.11 & 543 & 542 & 0.96 & 0.00 & 488 & 6.8 & 15.10 & 10.11 & 3 & 3595 \\
\hline
\end{tabular}




\begin{tabular}{|c|c|c|c|c|c|c|c|c|c|c|c|c|c|c|c|c|c|}
\hline Core, & \multicolumn{3}{|c|}{ Depth CSF (m) } & \multirow[b]{2}{*}{$\mathrm{pH}$} & \multirow{2}{*}{$\begin{array}{c}\text { Alkalinity } \\
(\mathrm{mM})\end{array}$} & \multirow{2}{*}{$\begin{array}{l}\text { Refractive } \\
\text { index }\end{array}$} & \multirow[b]{2}{*}{ Salinity } & \multirow{2}{*}{$\begin{array}{c}\text { Chlorinity } \\
(\mathrm{mM})\end{array}$} & \multirow{2}{*}{$\underset{(\mathrm{mM})}{\mathrm{Cl}}$} & \multirow{2}{*}{$\begin{array}{c}\mathrm{Br} \\
(\mathrm{mM})\end{array}$} & \multirow{2}{*}{$\begin{array}{c}\mathrm{SO}_{4} \\
(\mathrm{mM})\end{array}$} & \multirow{2}{*}{$\underset{(\mathrm{mM})}{\mathrm{Na}}$} & \multirow{2}{*}{$\underset{(\mathrm{mM})}{\mathrm{K}}$} & \multirow{2}{*}{$\begin{array}{c}\mathrm{Mg} \\
(\mathrm{mM})\end{array}$} & \multirow{2}{*}{$\begin{array}{c}\mathrm{Ca} \\
(\mathrm{mM})\end{array}$} & \multirow{2}{*}{$\begin{array}{c}\mathrm{PO}_{4} \\
(\mu \mathrm{m})\end{array}$} & \multirow{2}{*}{$\begin{array}{l}\mathrm{NH}_{4} \\
(\mu \mathrm{m})\end{array}$} \\
\hline section & Top & Bottom & Average & & & & & & & & & & & & & & \\
\hline $47 X-5$ & 386.72 & 387.10 & 386.91 & 7.9 & 7.08 & 1.33889 & 32.50 & 549 & 548 & - & 0.00 & 485 & 6.8 & 18.71 & 11.46 & 1 & 3224 \\
\hline $48 X-5$ & 396.98 & 397.40 & 397.19 & 8.2 & 5.68 & 1.33880 & 32.00 & 542 & 541 & 0.93 & 0.76 & 486 & 6.7 & 16.45 & 10.56 & 1 & 3153 \\
\hline $49 X-4$ & 404.68 & 405.09 & 404.89 & 8.4 & 6.37 & 1.33877 & 31.83 & 544 & 543 & 0.94 & 0.00 & 488 & 7.5 & 14.89 & 11.06 & - & 2985 \\
\hline & \multicolumn{17}{|c|}{ 316-C0006F- } \\
\hline $2 \mathrm{R}-2$ & 405.52 & 405.91 & 405.72 & 8.2 & 7.12 & 1.33876 & 31.78 & 553 & 552 & 0.95 & 0.00 & 498 & 5.6 & 15.19 & 11.29 & 0 & 2385 \\
\hline 3R-1 & 414.00 & 414.39 & 414.20 & 8.1 & 5.82 & 1.33872 & 31.56 & 545 & 544 & 0.94 & 0.00 & 490 & 5.9 & 15.16 & 10.95 & 3 & 2234 \\
\hline $4 \mathrm{R}-2$ & 424.91 & 425.27 & 425.09 & 8.1 & 6.04 & 1.33885 & 32.28 & 546 & 545 & 0.92 & 1.20 & 489 & 6.6 & 17.15 & 11.13 & 4 & 2570 \\
\hline $5 R-1$ & 434.25 & 434.50 & 434.37 & 7.8 & 6.12 & 1.33874 & 31.67 & 545 & 544 & 0.93 & 0.00 & 493 & 6.1 & 14.45 & 10.45 & 4 & 2252 \\
\hline 6R-1 & 439.08 & 439.41 & 439.25 & 7.9 & 4.20 & 1.33878 & 31.89 & 551 & 550 & 0.90 & 1.19 & 493 & 6.8 & 17.90 & 10.06 & 0 & 1784 \\
\hline $7 R-1$ & 448.40 & 448.66 & 448.53 & 7.5 & 6.34 & 1.33869 & 31.39 & 544 & 543 & 0.94 & 0.00 & 493 & 5.7 & 13.71 & 10.75 & 0 & 1634 \\
\hline $8 \mathrm{R}-1$ & 458.03 & 458.41 & 458.22 & 7.6 & 6.88 & 1.33869 & 31.39 & 542 & 541 & 0.89 & 0.00 & 490 & 5.1 & 14.00 & 12.02 & 3 & 1607 \\
\hline 9R-1 & 467.04 & 467.45 & 467.24 & 7.6 & 8.17 & 1.33876 & 31.78 & 545 & 544 & 0.91 & 0.00 & 492 & 5.6 & 14.62 & 12.23 & 4 & 1563 \\
\hline 10R-1 & 477.25 & 477.50 & 477.37 & 7.8 & 7.75 & 1.33875 & 31.72 & 544 & 543 & 0.92 & 0.00 & 493 & 5.8 & 12.83 & 12.78 & 4 & 1256 \\
\hline $11 \mathrm{R}-1 \mathrm{a}$ & 485.50 & 485.64 & 485.57 & 8.1 & 6.00 & 1.33884 & 32.22 & 542 & 542 & 0.88 & 1.30 & 482 & 7.0 & 18.39 & 12.13 & 4 & 868 \\
\hline $11 \mathrm{R}-1 \mathrm{~b}$ & 485.88 & 486.20 & 486.04 & - & - & 1.33869 & 31.39 & - & 0 & - & 0.00 & - & 6.6 & 12.78 & 12.47 & - & - \\
\hline $12 \mathrm{R}-2$ & 496.44 & 496.84 & 496.64 & 8.1 & 6.91 & 1.33873 & 31.61 & 544 & 543 & 0.91 & 0.00 & 492 & 5.7 & 12.37 & 13.32 & 5 & 1271 \\
\hline $13 \mathrm{R}-2$ & 505.90 & 506.30 & 506.10 & 8.2 & 4.65 & 1.33865 & 31.17 & 541 & 540 & 0.89 & 0.69 & 481 & 6.2 & 15.81 & 13.48 & 3 & 1165 \\
\hline 14R-2 & 516.58 & 517.02 & 516.80 & 8.0 & 5.95 & 1.33881 & 32.06 & 543 & 542 & 0.90 & 0.71 & 488 & 6.1 & 13.62 & 13.75 & 2 & 1020 \\
\hline 15R-1 & 523.50 & 523.90 & 523.70 & 8.0 & 5.02 & 1.33867 & 31.28 & 542 & 542 & 0.89 & 0.72 & 485 & 4.3 & 14.10 & 15.31 & 4 & 1005 \\
\hline 16R-1 & 534.00 & 534.42 & 534.21 & 7.5 & 4.02 & 1.33892 & 32.67 & 562 & 562 & 0.88 & 1.85 & 499 & 4.8 & 15.67 & 16.86 & 3 & 1020 \\
\hline 17R-1 & 542.65 & 543.06 & 542.86 & 7.6 & 3.89 & 1.33869 & 31.39 & 535 & 534 & 0.86 & 5.83 & 488 & 4.7 & 12.42 & 15.81 & 4 & 784 \\
\hline 18R-1 & 553.11 & 553.50 & 553.31 & 7.7 & 3.34 & 1.33876 & 31.78 & 538 & 538 & 0.88 & 4.74 & 492 & 3.6 & 10.90 & 16.69 & 3 & 700 \\
\hline $19 \mathrm{R}-3$ & 565.26 & 565.67 & 565.46 & - & - & 1.33856 & 30.67 & 521 & 520 & 0.83 & 6.03 & 469 & 3.8 & 11.96 & 17.69 & 3 & 890 \\
\hline 20R-1 & 571.18 & 571.49 & 571.34 & - & - & 1.33849 & 30.28 & 519 & 518 & 0.84 & 4.12 & 468 & 3.2 & 9.80 & 17.96 & 3 & 769 \\
\hline $22 \mathrm{R}-1$ & 590.00 & 590.42 & 590.21 & 7.8 & 3.32 & 1.33870 & 31.44 & 532 & 531 & 0.86 & 4.01 & 477 & 4.8 & 13.85 & 16.16 & - & 656 \\
\hline
\end{tabular}

Notes: $\mathrm{CSF}=$ core depth below seafloor. Na calculated from charge balance. $-=$ not analyzed . 
Table T13. Uncorrected concentrations of minor elements in interstitial waters, Site C0006. (See table notes.) (Continued on next page.)

\begin{tabular}{|c|c|c|c|c|c|c|c|c|c|c|c|}
\hline \multirow{2}{*}{$\begin{array}{c}\text { Core, } \\
\text { section }\end{array}$} & \multicolumn{3}{|c|}{ Depth CSF (m) } & \multicolumn{8}{|c|}{ Minor elements $(\mu \mathrm{m})$} \\
\hline & Top & Bottom & Average & $\mathrm{Li}$ & $B$ & $\mathrm{Sr}$ & $\mathrm{Ba}^{*}$ & $\mathrm{Ba}^{\dagger}$ & $\mathrm{Si}$ & $\mathrm{Fe}$ & $\mathrm{Mn}$ \\
\hline \multicolumn{12}{|c|}{ 316-C0006C- } \\
\hline $1 \mathrm{H}-2$ & 1.27 & 1.48 & 1.37 & 11.73 & 443 & 66 & 10.3 & 10.3 & 744 & 0.52 & 0.57 \\
\hline $1 \mathrm{H}-6$ & 5.97 & 6.19 & 6.08 & 10.53 & 442 & 68 & 10.2 & 10.2 & 642 & 0.66 & 1.50 \\
\hline \multicolumn{12}{|c|}{ 316-C0006D- } \\
\hline $1 \mathrm{H}-2$ & 1.21 & 1.43 & 1.32 & 20.55 & 494 & 74 & 2.4 & 2.5 & 613 & 0.27 & 0.59 \\
\hline $1 \mathrm{H}-5$ & 4.04 & 4.26 & 4.15 & 14.53 & 461 & 70 & 10.8 & 10.8 & 764 & 0.28 & 0.54 \\
\hline \multicolumn{12}{|c|}{ 316-C0006E- } \\
\hline $1 \mathrm{H}-2$ & 1.21 & 1.43 & 1.32 & 31.78 & 556 & 80 & 0.6 & 0.5 & 437 & 0.72 & 6.91 \\
\hline $1 \mathrm{H}-5$ & 4.24 & 4.47 & 4.36 & 23.85 & 514 & 74 & 3.6 & 3.4 & 581 & 0.68 & 0.64 \\
\hline $2 \mathrm{H}-3$ & 7.79 & 8.02 & 7.91 & 19.91 & 554 & 76 & 7.1 & 6.7 & 646 & 0.48 & 0.68 \\
\hline $2 \mathrm{H}-7$ & 12.09 & 12.33 & 12.21 & 15.10 & 494 & 75 & 12.7 & 12.5 & 695 & 0.80 & 0.74 \\
\hline $3 \mathrm{H}-3$ & 17.29 & 17.52 & 17.40 & 13.20 & 456 & 77 & 11.7 & 11.0 & 563 & 4.88 & 1.30 \\
\hline $3 \mathrm{H}-7$ & 21.66 & 21.89 & 21.77 & 15.67 & 484 & 80 & 10.9 & 10.1 & 595 & 39.96 & 3.29 \\
\hline $4 \mathrm{H}-5$ & 29.92 & 30.16 & 30.04 & 12.56 & 433 & 79 & 10.3 & 9.7 & 524 & 2.33 & 4.66 \\
\hline $5 \mathrm{H}-3$ & 35.84 & 36.06 & 35.95 & 11.61 & 419 & 83 & 11.7 & 10.7 & 468 & 5.02 & 4.55 \\
\hline $7 \mathrm{H}-4$ & 42.92 & 43.16 & 43.04 & 13.42 & 409 & 89 & 12.1 & 11.3 & 471 & 1.93 & 4.17 \\
\hline $8 \mathrm{H}-4$ & 51.79 & 52.03 & 51.91 & 14.82 & 437 & 89 & 12.3 & 10.9 & 568 & 8.85 & 5.24 \\
\hline $9 \mathrm{H}-5$ & 62.41 & 62.64 & 62.53 & 14.49 & 413 & 91 & 12.4 & 11.3 & 538 & 6.46 & 7.46 \\
\hline $10 \mathrm{H}-8$ & 64.51 & 64.67 & 64.59 & 14.65 & 442 & 91 & 12.9 & 12.2 & 447 & 13.27 & 14.66 \\
\hline $11 \mathrm{H}-4$ & 67.70 & 67.91 & 67.81 & 13.43 & 416 & 93 & 12.7 & 11.3 & 490 & 28.21 & 7.08 \\
\hline $12 \mathrm{H}-6$ & 76.31 & 76.52 & 76.41 & 8.2 & 404 & 74 & 8.5 & 9.0 & 442 & 21.94 & 5.55 \\
\hline $15 X-4$ & 81.76 & 81.97 & 81.87 & 10.1 & 395 & 79 & 8.7 & 9.0 & 517 & 0.90 & 3.18 \\
\hline $16 X-2$ & 90.11 & 90.34 & 90.23 & 15.3 & 314 & 80 & 9.7 & 10.4 & 447 & 1.82 & 5.30 \\
\hline $17 X-3$ & 100.30 & 100.55 & 100.43 & 14.0 & 372 & 80 & 11.0 & 11.6 & 488 & 0.95 & 4.39 \\
\hline $19 X-5$ & 119.76 & 120.08 & 119.92 & 13.7 & 389 & 81 & 10.4 & 10.4 & 593 & 4.86 & 5.22 \\
\hline $20 x-7$ & 132.85 & 133.18 & 133.01 & 32.2 & 246 & 80 & 10.9 & 12.0 & 335 & 9.78 & 4.65 \\
\hline $21 X-3$ & 137.38 & 137.70 & 137.54 & 13.1 & 251 & 74 & 9.2 & 10.0 & 563 & 0.63 & 3.51 \\
\hline $22 X-3$ & 146.83 & 147.18 & 147.00 & 14.8 & 223 & 76 & 9.6 & 10.0 & 417 & 0.55 & 3.15 \\
\hline $23 X-4$ & 157.74 & 158.08 & 157.91 & 13.6 & 251 & 77 & 9.1 & 9.9 & 661 & 0.77 & 4.02 \\
\hline $25 X-7$ & 180.79 & 181.13 & 180.96 & 28.0 & 237 & 85 & 13.5 & 14.1 & 522 & 1.25 & 5.02 \\
\hline $26 X-4$ & 186.65 & 186.96 & 186.80 & 16.1 & 238 & 79 & 11.9 & 13.1 & 701 & 2.60 & 5.04 \\
\hline $27 X-5$ & 197.49 & 197.87 & 197.68 & 20.2 & 203 & 82 & 12.1 & 12.1 & 471 & 6.65 & 4.94 \\
\hline $28 X-3$ & 203.81 & 204.17 & 203.99 & 15.7 & 177 & 81 & 11.3 & 12.1 & 542 & 50.91 & 8.70 \\
\hline $29 X-7$ & 219.04 & 219.38 & 219.21 & 27.8 & 154 & 87 & 13.2 & 14.0 & 636 & 0.86 & 5.54 \\
\hline $30 x-3$ & 223.16 & 223.54 & 223.35 & 21.9 & 183 & 86 & 12.7 & 13.0 & 661 & 1.03 & 5.50 \\
\hline $31 X-3$ & 232.32 & 232.69 & 232.50 & 22.2 & 194 & 85 & 12.3 & 14.0 & 615 & 0.21 & 4.80 \\
\hline $32 X-4$ & 243.21 & 243.59 & 243.40 & 22.2 & 219 & 85 & 12.3 & 13.3 & 741 & 0.45 & 4.46 \\
\hline $34 X-5$ & 263.62 & 264.00 & 263.81 & 25.6 & 185 & 89 & 13.0 & 13.9 & 572 & 7.14 & 5.63 \\
\hline $35 X-2$ & 268.69 & 269.06 & 268.87 & 19.2 & 171 & 87 & 12.7 & 13.5 & 505 & 2.32 & 7.46 \\
\hline $36 X-4$ & 281.56 & 281.92 & 281.74 & 19.7 & 215 & 81 & 12.5 & 13.8 & 707 & 2.76 & 6.11 \\
\hline $37 X-5$ & 292.12 & 292.49 & 292.30 & 21.4 & 180 & 86 & 12.9 & 13.9 & 633 & 0.75 & 4.19 \\
\hline $38 X-2$ & 296.70 & 296.91 & 296.80 & 22.3 & 204 & 85 & 12.6 & 14.0 & 717 & 0.64 & 4.43 \\
\hline $39 X-4$ & 309.69 & 310.07 & 309.88 & 27.9 & 196 & 88 & 13.2 & 15.2 & 596 & 2.06 & 4.62 \\
\hline $40 x-7$ & 322.01 & 322.41 & 322.21 & 23.8 & 194 & 91 & 12.8 & 13.5 & 774 & 0.48 & 5.48 \\
\hline $41 X-4$ & 328.83 & 329.21 & 329.02 & 26.2 & 141 & 92 & 12.6 & 13.2 & 763 & 2.09 & 4.42 \\
\hline $42 X-5$ & 339.58 & 339.99 & 339.78 & 25.6 & 189 & 95 & 13.1 & 16.3 & 657 & 12.00 & 6.12 \\
\hline $43 X-5$ & 349.11 & 349.49 & 349.30 & 31.5 & 153 & 97 & 13.2 & 14.4 & 417 & 3.18 & 6.09 \\
\hline $44 X-5$ & 358.99 & 359.37 & 359.18 & 29.2 & 201 & 101 & 13.9 & 15.6 & 635 & 0.75 & 6.97 \\
\hline $45 X-4$ & 366.66 & 367.05 & 366.86 & 31.0 & 170 & 102 & 15.4 & 15.8 & 715 & 0.78 & 6.68 \\
\hline $46 X-5$ & 377.60 & 377.99 & 377.80 & 29.8 & 147 & 105 & 19.0 & 19.4 & 385 & 0.59 & 3.39 \\
\hline $47 X-5$ & 386.72 & 387.10 & 386.91 & 34.3 & 162 & 117 & 24.3 & 13.4 & 573 & 0.60 & 6.89 \\
\hline $48 X-5$ & 396.98 & 397.40 & 397.19 & 38.5 & 153 & 114 & 34.7 & 12.6 & 443 & 0.52 & 5.40 \\
\hline $49 X-4$ & 404.68 & 405.09 & 404.89 & 54.6 & 169 & 116 & 25.7 & 8.8 & 328 & 0.43 & 5.49 \\
\hline \multicolumn{12}{|c|}{ 316-C0006F- } \\
\hline $2 \mathrm{R}-2$ & 405.52 & 405.91 & 405.72 & 41.9 & 186 & 124 & 66.6 & 7.5 & 560 & 0.95 & 9.28 \\
\hline $3 R-1$ & 414.00 & 414.39 & 414.20 & 44.5 & 166 & 125 & 93.7 & 11.3 & 764 & 0.18 & 7.97 \\
\hline $4 R-2$ & 424.91 & 425.27 & 425.09 & 55.8 & 144 & 113 & 24.0 & 2.3 & 522 & 0.14 & 3.97 \\
\hline $5 R-1$ & 434.25 & 434.50 & 434.37 & 64.4 & 166 & 109 & 35.4 & 3.4 & 651 & 0.12 & 5.23 \\
\hline $6 \mathrm{R}-1$ & 439.08 & 439.41 & 439.25 & 69.6 & 180 & 104 & 31.4 & 2.3 & 733 & 0.22 & 3.72 \\
\hline 7R-1 & 448.40 & 448.66 & 448.53 & 80.4 & 155 & 119 & 74.7 & 10.7 & 911 & 0.92 & 4.03 \\
\hline $8 \mathrm{R}-1$ & 458.03 & 458.41 & 458.22 & 92.7 & 164 & 117 & 41.8 & 7.7 & 982 & 0.15 & 8.56 \\
\hline $9 \mathrm{R}-1$ & 467.04 & 467.45 & 467.24 & 96.8 & 164 & 107 & 11.9 & 5.5 & 923 & 3.27 & 11.65 \\
\hline $10 \mathrm{R}-1$ & 477.25 & 477.50 & 477.37 & 102.9 & 167 & 114 & 95.0 & 7.7 & 928 & 2.45 & 19.10 \\
\hline $11 \mathrm{R}-1 \mathrm{a}$ & 485.50 & 485.64 & 485.57 & 91.6 & 142 & 95 & 24.9 & 6.9 & 555 & 0.13 & 9.75 \\
\hline $11 \mathrm{R}-1 \mathrm{~b}$ & 485.88 & 486.20 & 486.04 & 101.7 & 69 & 104 & 31.4 & 4.2 & 393 & 0.00 & 6.40 \\
\hline $12 \mathrm{R}-2$ & 496.44 & 496.84 & 496.64 & 111.5 & 140 & 107 & 52.5 & 2.8 & 743 & 0.25 & 16.78 \\
\hline
\end{tabular}


Table T13 (continued).

\begin{tabular}{|c|c|c|c|c|c|c|c|c|c|c|c|}
\hline \multirow{2}{*}{$\begin{array}{l}\text { Core, } \\
\text { section }\end{array}$} & \multicolumn{3}{|c|}{ Depth CSF (m) } & \multicolumn{8}{|c|}{ Minor elements $(\mu \mathrm{m})$} \\
\hline & Top & Bottom & Average & $\mathrm{Li}$ & B & $\mathrm{Sr}$ & $\mathrm{Ba}^{*}$ & $\mathrm{Ba}^{\dagger}$ & $\mathrm{Si}$ & $\mathrm{Fe}$ & $\mathrm{Mn}$ \\
\hline $13 R-2$ & 505.90 & 506.30 & 506.10 & 108.6 & 118 & 96 & 27.2 & 4.2 & 562 & 0.11 & 6.99 \\
\hline 14R-2 & 516.58 & 517.02 & 516.80 & 121.7 & 118 & 102 & 41.6 & 3.2 & 459 & 0.00 & 8.20 \\
\hline $15 \mathrm{R}-1$ & 523.50 & 523.90 & 523.70 & 117.0 & 125 & 106 & 43.8 & 2.7 & 632 & 0.06 & 21.44 \\
\hline $16 \mathrm{R}-1$ & 534.00 & 534.42 & 534.21 & 113.5 & 175 & 106 & 14.1 & 5.6 & 543 & 0.21 & 36.71 \\
\hline 17R-1 & 542.65 & 543.06 & 542.86 & 126.0 & 123 & 106 & 48.1 & 4.5 & 533 & 0.00 & 16.85 \\
\hline 18R-1 & 553.11 & 553.50 & 553.31 & 129.2 & 133 & 108 & 19 & 3 & 698 & 0.32 & 18.49 \\
\hline $19 R-3$ & 565.26 & 565.67 & 565.46 & 123.1 & 102 & 104 & 8 & 5 & 166 & 0 & 13.31 \\
\hline $20 \mathrm{R}-1$ & 571.18 & 571.49 & 571.34 & 133.0 & 94 & 109 & 17 & 2 & 191 & 0 & 9.19 \\
\hline $22 \mathrm{R}-1$ & 590.00 & 590.42 & 590.21 & 126.6 & 167 & 101 & 7 & 2 & 453 & 0 & 17.84 \\
\hline
\end{tabular}

Notes: * = shipboard ICP-AES, $\dagger=$ shore-based ICP-MS. CSF = core depth below seafloor. 
Table T14. Uncorrected concentrations of trace elements and $\delta^{18} \mathrm{O}$ in interstitial waters, Site C0006. (See table notes.) (Continued on next page.)

\begin{tabular}{|c|c|c|c|c|c|c|c|c|c|c|c|c|c|}
\hline \multirow{2}{*}{$\begin{array}{l}\text { Core, } \\
\text { section }\end{array}$} & \multicolumn{3}{|c|}{ Depth CSF (m) } & \multirow{2}{*}{$\begin{array}{c}V \\
(n M)\end{array}$} & \multirow{2}{*}{$\begin{array}{c}\mathrm{Cu} \\
(\mathrm{nM})\end{array}$} & \multirow{2}{*}{$\begin{array}{l}\mathrm{Zn} \\
(\mathrm{nM})\end{array}$} & \multirow{2}{*}{$\begin{array}{c}\mathrm{Rb} \\
(\mu \mathrm{M})\end{array}$} & \multirow{2}{*}{$\begin{array}{c}\text { Mo } \\
(\mu \mathrm{M})\end{array}$} & \multirow{2}{*}{$\begin{array}{c}\text { Cs } \\
(\mathrm{nM})\end{array}$} & & U & $\gamma$ & $\delta^{18} \mathrm{O}$ \\
\hline & Top & Bottom & Average & & & & & & & $(\mathrm{nM})$ & $(\mathrm{nM})$ & $(\mathrm{pM})$ & $(\% \circ)$ \\
\hline 316-C000 & & & & & & & & & & & & & \\
\hline $1 \mathrm{H}-2$ & 1.27 & 1.48 & 1.37 & - & - & 75 & 1.31 & 46 & - & - & - & - & -0.42 \\
\hline $1 \mathrm{H}-6$ & 5.97 & 6.19 & 6.08 & - & - & 60 & 1.34 & 53 & - & - & - & - & -0.51 \\
\hline 316-C000 & & & & & & & & & & & & & \\
\hline $1 \mathrm{H}-2$ & 1.21 & 1.43 & 1.32 & 30.4 & 722.6 & 311 & 1.54 & 31 & 3.7 & 0.6 & 17.6 & 1.66 & -0.02 \\
\hline $1 \mathrm{H}-5$ & 4.04 & 4.26 & 4.15 & 40.3 & 87.2 & 119 & 1.41 & 28 & 4.9 & 0.7 & 0.5 & 2.1 & -0.35 \\
\hline 316-C000 & & & & & & & & & & & & & \\
\hline $1 \mathrm{H}-2$ & 1.21 & 1.43 & 1.32 & 29.9 & 136.1 & 179 & 1.70 & 84 & 4.4 & 0.6 & 25.7 & 1.88 & 0.19 \\
\hline $1 \mathrm{H}-5$ & 4.24 & 4.47 & 4.36 & 39.8 & 140.9 & 90 & 1.55 & 29 & 4.6 & 1.0 & 0.7 & 1.50 & -0.07 \\
\hline $2 \mathrm{H}-3$ & 7.79 & 8.02 & 7.91 & 18.1 & 57.0 & 78 & 1.44 & 26 & 4.5 & 0.4 & 0.5 & 2.0 & -0.20 \\
\hline $2 \mathrm{H}-7$ & 12.09 & 12.33 & 12.21 & 40.4 & 210.4 & 202 & 1.36 & 32 & 4.4 & 0.6 & 1.5 & 6.4 & -0.51 \\
\hline $3 \mathrm{H}-3$ & 17.29 & 17.52 & 17.40 & 81.4 & 70.7 & 125 & 1.29 & 121 & 4.9 & 7.4 & 1.3 & 2.5 & -0.88 \\
\hline $3 \mathrm{H}-7$ & 21.66 & 21.89 & 21.77 & 89.5 & 65.4 & 121 & 1.24 & 366 & 5.8 & 1.1 & 4.9 & 0.80 & -0.95 \\
\hline $4 \mathrm{H}-5$ & 29.92 & 30.16 & 30.04 & 63.1 & 61.7 & 73 & 1.22 & 149 & 6.4 & 0.5 & 2.9 & 1.73 & -1.76 \\
\hline $5 \mathrm{H}-3$ & 35.84 & 36.06 & 35.95 & 30.3 & 60.9 & 102 & 1.12 & 131 & 5.3 & 1.3 & 0.8 & 1.81 & -1.71 \\
\hline $7 \mathrm{H}-4$ & 42.92 & 43.16 & 43.04 & 56.0 & $1,265.2$ & 233 & 1.06 & 126 & 5.1 & 0.8 & 2.9 & 2.0 & -2.02 \\
\hline $8 \mathrm{H}-4$ & 51.79 & 52.03 & 51.91 & 31.9 & 74.6 & 144 & 1.05 & 29 & 5.7 & 1.5 & 0.7 & 0.46 & -2.30 \\
\hline $9 \mathrm{H}-5$ & 62.41 & 62.64 & 62.53 & 18.6 & 68.4 & 215 & 1.10 & 88 & 5.1 & 0.4 & 1.1 & 3.8 & -2.60 \\
\hline $10 \mathrm{H}-8$ & 64.51 & 64.67 & 64.59 & 24.6 & 75.2 & 132 & 1.08 & 185 & 4.9 & 0.9 & 2.7 & 0.72 & -2.52 \\
\hline $11 \mathrm{H}-4$ & 67.70 & 67.91 & 67.81 & 29.4 & 164.8 & 341 & 1.01 & 139 & 4.4 & 1.5 & 0.9 & 1.18 & -2.85 \\
\hline $12 \mathrm{H}-6$ & 76.31 & 76.52 & 76.41 & 29.4 & $3,220.9$ & 319 & 1.03 & 153 & 5.2 & 0.9 & 1.4 & 2.7 & -2.68 \\
\hline $15 X-4$ & 81.76 & 81.97 & 81.87 & 47.4 & 590.8 & 408 & 1.11 & 94 & 5.5 & 0.6 & 1.7 & 1.56 & -3.00 \\
\hline $16 X-2$ & 90.11 & 90.34 & 90.23 & 18.5 & 380.0 & 260 & 1.22 & 54 & 7.1 & 0.7 & 0.9 & - & -2.99 \\
\hline $17 X-3$ & 100.30 & 100.55 & 100.43 & 36.1 & 628.3 & 634 & 1.09 & 320 & 6.6 & 1.2 & 2.2 & 2.6 & -2.81 \\
\hline $19 X-5$ & 119.76 & 120.08 & 119.92 & 30.7 & 613.9 & 184 & 0.88 & 58 & 5.8 & 1.7 & 1.1 & 1.06 & -3.02 \\
\hline $20 X-7$ & 132.85 & 133.18 & 133.01 & 16.0 & 141.3 & 406 & - & 133 & 8.7 & 2.2 & 1.2 & 1.20 & -2.83 \\
\hline $21 X-3$ & 137.38 & 137.70 & 137.54 & 26.4 & $6,115.2$ & 565 & 0.95 & 124 & 5.0 & 9.8 & 1.1 & - & -3.23 \\
\hline $22 X-3$ & 146.83 & 147.18 & 147.00 & 25.9 & $2,207.2$ & 252 & 1.01 & 143 & 5.1 & 0.5 & 1.9 & 2.3 & -3.20 \\
\hline $23 X-4$ & 157.74 & 158.08 & 157.91 & 42.3 & $5,654.8$ & 606 & 0.92 & 89 & 4.7 & 0.6 & 0.9 & 1.37 & -3.30 \\
\hline $25 X-7$ & 180.79 & 181.13 & 180.96 & 12.0 & $7,708.8$ & 242 & - & 56 & 7.6 & 0.3 & 1.5 & 1.04 & -3.21 \\
\hline $26 X-4$ & 186.65 & 186.96 & 186.80 & 12.1 & 299.3 & 207 & 0.96 & 49 & 5.3 & 0.6 & 0.5 & 1.84 & -3.32 \\
\hline $27 X-5$ & 197.49 & 197.87 & 197.68 & 11.9 & $1,473.3$ & 249 & 0.99 & 164 & 4.5 & 2.1 & 0.8 & 0.60 & -2.88 \\
\hline $28 \mathrm{X}-3$ & 203.81 & 204.17 & 203.99 & 15.7 & 366.5 & 64 & 0.96 & 850 & 4.9 & 1.6 & 0.2 & 0.96 & -3.52 \\
\hline $29 \mathrm{X}-7$ & 219.04 & 219.38 & 219.21 & 13.1 & $1,606.8$ & 476 & 1.02 & 108 & 4.4 & 0.3 & 1.5 & 2.7 & -3.64 \\
\hline $30 X-3$ & 223.16 & 223.54 & 223.35 & 11.7 & 793.1 & 167 & 0.96 & 91 & 4.8 & 0.2 & 1.2 & 1.56 & -3.55 \\
\hline $31 X-3$ & 232.32 & 232.69 & 232.50 & 21.6 & $4,409.4$ & 182 & 0.89 & 496 & 5.0 & 0.3 & 1.3 & 1.64 & -3.36 \\
\hline $32 X-4$ & 243.21 & 243.59 & 243.40 & 33.8 & $8,465.8$ & 1,085 & 0.84 & 143 & 4.2 & 0.7 & 1.4 & 2.0 & -3.85 \\
\hline $34 X-5$ & 263.62 & 264.00 & 263.81 & 6.9 & $6,049.0$ & 498 & 0.89 & 85 & 5.5 & 0.3 & 0.4 & 0.75 & -3.48 \\
\hline $35 X-2$ & 268.69 & 269.06 & 268.87 & 19.0 & $2,064.0$ & 662 & 0.83 & 260 & 4.4 & 0.3 & 0.8 & 1.31 & -3.41 \\
\hline $36 X-4$ & 281.56 & 281.92 & 281.74 & 9.4 & 278.0 & 104 & 0.89 & 87 & 5.0 & 0.7 & 0.5 & 1.06 & -3.63 \\
\hline $37 X-5$ & 292.12 & 292.49 & 292.30 & 17.5 & 225.8 & 205 & 0.92 & 217 & 5.3 & 0.1 & 2.7 & 0.63 & -3.76 \\
\hline $38 \mathrm{X}-2$ & 296.70 & 296.91 & 296.80 & 15.0 & $2,287.6$ & 95 & 0.93 & 174 & 5.8 & 1.3 & 1.2 & 0.59 & -3.59 \\
\hline $39 X-4$ & 309.69 & 310.07 & 309.88 & 18.5 & $4,766.2$ & 324 & 1.07 & 378 & 6.6 & 0.2 & 1.8 & 2.3 & -3.70 \\
\hline $40 X-7$ & 322.01 & 322.41 & 322.21 & 26.3 & $2,268.1$ & 473 & 0.78 & 59 & 4.1 & 0.5 & 0.8 & 0.55 & -3.99 \\
\hline $41 X-4$ & 328.83 & 329.21 & 329.02 & 19.1 & $3,660.1$ & 579 & 0.83 & 88 & 3.9 & 5.4 & 1.3 & 0.59 & -4.01 \\
\hline $42 X-5$ & 339.58 & 339.99 & 339.78 & 11.5 & 266.7 & 443 & 0.89 & 634 & 5.4 & 0.2 & 0.6 & 0.59 & -3.65 \\
\hline $43 X-5$ & 349.11 & 349.49 & 349.30 & 8.1 & $2,499.3$ & 265 & 1.00 & 841 & 5.7 & 0.7 & 1.1 & 0.26 & -3.84 \\
\hline $44 X-5$ & 358.99 & 359.37 & 359.18 & 13.0 & 180.2 & 30 & 0.99 & 798 & 5.6 & 0.5 & 1.6 & 1.11 & -3.59 \\
\hline $45 X-4$ & 366.66 & 367.05 & 366.86 & 8.1 & 298.8 & 519 & 1.01 & 279 & 4.9 & 0.3 & 1.0 & 0.44 & -4.10 \\
\hline $46 X-5$ & 377.60 & 377.99 & 377.80 & 26.7 & $4,746.4$ & 445 & 1.00 & 424 & 5.1 & 0.9 & 2.5 & 0.97 & -4.04 \\
\hline $47 X-5$ & 386.72 & 387.10 & 386.91 & 7.8 & $1,848.8$ & 227 & 0.94 & 215 & 5.1 & 0.4 & 0.7 & 1.17 & -3.61 \\
\hline $48 X-5$ & 396.98 & 397.40 & 397.19 & 14.6 & 324.9 & 78 & 0.98 & 845 & 5.1 & 0.3 & 1.6 & 1.03 & -3.65 \\
\hline $49 X-4$ & 404.68 & 405.09 & 404.89 & 19.3 & $1,253.1$ & 555 & 1.03 & 635 & 5.3 & 16 & 5.5 & 0.82 & -3.28 \\
\hline $316-\mathrm{COO}$ & & & & & & & & & & & & & \\
\hline $2 \mathrm{R}-2$ & 405.52 & 405.91 & 405.72 & 22.1 & 696.1 & 322 & 0.75 & 125 & 3.2 & 0.3 & 1.2 & 1.17 & -3.42 \\
\hline $3 R-1$ & 414.00 & 414.39 & 414.20 & 17.8 & $1,468.3$ & 345 & 0.75 & 77 & 3.2 & 0.7 & 1.1 & 1.24 & - \\
\hline $4 \mathrm{R}-2$ & 424.91 & 425.27 & 425.09 & 27.3 & $8,950.8$ & 393 & 0.91 & 319 & 4.1 & 1.0 & 3.6 & 0.45 & - \\
\hline $5 \mathrm{R}-1$ & 434.25 & 434.50 & 434.37 & 29.6 & $28,901.5$ & 1,136 & 0.85 & 123 & 3.6 & 2.2 & 3.1 & 1.17 & -3.57 \\
\hline 6R-1 & 439.08 & 439.41 & 439.25 & 37.2 & $6,070.4$ & 436 & 0.81 & 432 & 3.3 & 1.8 & 3.9 & 0.53 & -1.60 \\
\hline 7R-1 & 448.40 & 448.66 & 448.53 & 25.8 & $18,698.9$ & 1,210 & 0.66 & 265 & 2.5 & 3.3 & 3.1 & 0.43 & - \\
\hline $8 \mathrm{R}-1$ & 458.03 & 458.41 & 458.22 & 12.1 & $23,097.6$ & 1,294 & 0.53 & 48 & 2.0 & 0.8 & 4.2 & 0.74 & - \\
\hline 9R-1 & 467.04 & 467.45 & 467.24 & 15.2 & $18,023.9$ & 879 & 0.64 & 94 & 2.5 & 2.7 & 3.2 & 0.86 & - \\
\hline 10R-1 & 477.25 & 477.50 & 477.37 & 7.0 & $2,208.6$ & 478 & 0.61 & 54 & 1.8 & 1.3 & 1.5 & 0.83 & -3.06 \\
\hline $11 \mathrm{R}-1 \mathrm{a}$ & 485.50 & 485.64 & 485.57 & 18.7 & $16,861.9$ & 239 & 0.73 & 187 & 2.3 & 1.5 & 9.2 & 0.51 & -3.34 \\
\hline $11 \mathrm{R}-1 \mathrm{~b}$ & 485.88 & 486.20 & 486.04 & 15.6 & $1,259.7$ & 93 & 0.67 & 691 & 2.3 & 2.1 & 5.7 & 0.30 & - \\
\hline $12 \mathrm{R}-2$ & 496.44 & 496.84 & 496.64 & 10.6 & $10,622.0$ & 589 & 0.67 & 593 & 2.4 & 1.8 & 5.2 & 0.51 & -3.23 \\
\hline
\end{tabular}


Table T14 (continued).

\begin{tabular}{|c|c|c|c|c|c|c|c|c|c|c|c|c|c|}
\hline \multirow{2}{*}{$\begin{array}{c}\text { Core, } \\
\text { section }\end{array}$} & \multicolumn{3}{|c|}{ Depth CSF (m) } & \multirow{2}{*}{$\begin{array}{c}\mathrm{V} \\
(\mathrm{nM})\end{array}$} & \multirow{2}{*}{$\begin{array}{c}\mathrm{Cu} \\
(\mathrm{nM})\end{array}$} & \multirow{2}{*}{$\underset{(\mathrm{nM})}{\mathrm{Zn}}$} & \multirow{2}{*}{$\begin{array}{c}\mathrm{Rb} \\
(\mu \mathrm{M})\end{array}$} & \multirow{2}{*}{$\begin{array}{c}\text { Mo } \\
(\mu \mathrm{M})\end{array}$} & \multirow{2}{*}{$\begin{array}{c}\mathrm{Cs} \\
(\mathrm{nM})\end{array}$} & \multirow{2}{*}{$\begin{array}{c}\mathrm{Pb} \\
(\mathrm{nM})\end{array}$} & \multirow{2}{*}{$\underset{(\mathrm{nM})}{\mathrm{U}}$} & \multirow{2}{*}{$\begin{array}{c}Y \\
(p M)\end{array}$} & \multirow{2}{*}{$\begin{array}{l}\delta^{18} \mathrm{O} \\
(\% o)\end{array}$} \\
\hline & Top & Bottom & Average & & & & & & & & & & \\
\hline $13 \mathrm{R}-2$ & 505.90 & 506.30 & 506.10 & 11.7 & $10,011.7$ & 431 & 0.71 & 330 & 2.7 & 1.0 & 5.1 & 0.30 & -4.19 \\
\hline $14 \mathrm{R}-2$ & 516.58 & 517.02 & 516.80 & 10.6 & $2,327.5$ & 449 & 0.60 & 434 & 2.4 & 1.5 & 1.9 & 0.92 & - \\
\hline $15 R-1$ & 523.50 & 523.90 & 523.70 & 4.7 & $4,813.4$ & 365 & 0.53 & 237 & 2.3 & 2.4 & 1.8 & 1.63 & -3.23 \\
\hline 16R-1 & 534.00 & 534.42 & 534.21 & 11.5 & $10,284.5$ & 280 & 0.57 & 145 & 2.4 & 0.9 & 2.4 & 0.52 & -3.25 \\
\hline 17R-1 & 542.65 & 543.06 & 542.86 & 10.9 & $25,404.6$ & 393 & 0.49 & 168 & 2.0 & 5.5 & 2.4 & 0.43 & -3.48 \\
\hline $18 \mathrm{R}-1$ & 553.11 & 553.50 & 553.31 & 8.1 & $21,107.7$ & 463 & 0.46 & 476 & 2.2 & 1.6 & 4.7 & 0.30 & - \\
\hline $19 R-3$ & 565.26 & 565.67 & 565.46 & 7.0 & $11,281.7$ & 204 & 0.45 & 727 & 2.6 & 2.5 & 5.1 & 0.24 & - \\
\hline $20 \mathrm{R}-1$ & 571.18 & 571.49 & 571.34 & 7.3 & $19,487.9$ & 284 & 0.50 & 505 & 2.7 & 0.9 & 3.6 & 0.41 & - \\
\hline $22 \mathrm{R}-1$ & 590.00 & 590.42 & 590.21 & 7.1 & $31,892.9$ & 465 & 0.68 & 455 & 3.0 & 0.8 & 4.4 & 0.15 & - \\
\hline
\end{tabular}

Notes: CSF $=$ core depth below seafloor. $-=$ not analyzed. 
Table T15. Headspace gas composition for safety monitoring in sediments, Site C0006. (See table notes.)

\begin{tabular}{|c|c|c|c|c|}
\hline \multirow{2}{*}{$\begin{array}{l}\text { Core, section, } \\
\text { interval }(\mathrm{cm})\end{array}$} & \multirow{2}{*}{$\begin{array}{l}\text { Depth } \\
\text { CSF (m) }\end{array}$} & \multicolumn{2}{|c|}{ Headspace gas (ppmv) } & \multirow[b]{2}{*}{$\mathrm{C}_{1} / \mathrm{C}_{2}$} \\
\hline & & Methane & Ethane & \\
\hline \multicolumn{5}{|l|}{ 316-C0006C- } \\
\hline $1 \mathrm{H}-1,119-123$ & 1.21 & $12,302.3$ & 0.0 & - \\
\hline \multicolumn{5}{|l|}{ 316-C0006D- } \\
\hline $1 \mathrm{H}-1,117-121$ & 1.19 & 31.7 & 0.0 & - \\
\hline \multicolumn{5}{|l|}{ 316-C0006E- } \\
\hline $1 \mathrm{H}-1,116.5-120.5$ & 1.19 & 24.4 & 0.0 & - \\
\hline $2 \mathrm{H}-1,136.5-140.5$ & 6.58 & 29.1 & 0.0 & - \\
\hline $3 \mathrm{H}-1,136.5-140.5$ & 16.08 & $12,246.0$ & 0.0 & - \\
\hline $4 \mathrm{H}-1,139.5-143.5$ & 25.61 & $14,685.1$ & 0.0 & - \\
\hline $5 \mathrm{H}-1,139-143$ & 34.63 & $8,907.5$ & 0.0 & - \\
\hline $7 \mathrm{H}-1,136.5-140.5$ & 40.08 & $5,113.1$ & 0.0 & - \\
\hline $8 \mathrm{H}-1,135.5-139.5$ & 49.57 & $14,032.3$ & 0.0 & - \\
\hline $9 \mathrm{H}-1,136-140$ & 59.09 & $12,884.1$ & 0.0 & - \\
\hline $11 \mathrm{H}-1,137-141$ & 66.06 & $10,654.1$ & 0.0 & - \\
\hline $12 \mathrm{H}-1,44-48$ & 71.94 & $7,469.1$ & 2.1 & 3,517 \\
\hline $15 X-1,137-141$ & 80.72 & $7,606.9$ & 0.0 & - \\
\hline $16 X-1,124-128$ & 90.09 & $7,364.0$ & 0.0 & - \\
\hline $17 X-1,137-141$ & 99.72 & $16,704.7$ & 3.4 & 4,954 \\
\hline $18 X-1,133-137$ & 107.68 & $5,975.1$ & 2.3 & 2,654 \\
\hline $19 X-1,105-109$ & 116.90 & $5,779.5$ & 1.9 & 3,113 \\
\hline $20 X-1,137.5-141.5$ & 126.73 & $6,740.1$ & 2.7 & 2,458 \\
\hline $21 X-1,141-145$ & 136.26 & $4,579.5$ & 0.0 & - \\
\hline $22 X-1,137-141$ & 145.72 & $11,339.1$ & 2.8 & 3,983 \\
\hline $23 X-1,136.5-140.5$ & 155.22 & $8,212.8$ & 2.6 & 3,209 \\
\hline $25 X-1,136.5-140.5$ & 174.22 & $6,219.2$ & 5.3 & 1,177 \\
\hline $26 \mathrm{X}-1,145-149$ & 183.80 & $7,271.5$ & 4.1 & 1,767 \\
\hline $27 X-1,137-141$ & 193.22 & $9,126.2$ & 4.1 & 2,239 \\
\hline $28 X-1,137-141$ & 202.72 & $3,199.4$ & 4.1 & 788 \\
\hline 29X-1, 139-143 & 212.24 & $5,573.7$ & 3.1 & 1,809 \\
\hline $30 X-1,137-141$ & 221.72 & $9,382.3$ & 3.7 & 2,540 \\
\hline $31 X-1,140-144$ & 231.25 & $5,334.5$ & 2.5 & 2,106 \\
\hline $32 X-1,138.5-142.5$ & 240.74 & $2,522.6$ & 0.0 & - \\
\hline $34 X-1,137-141$ & 259.72 & $14,442.0$ & 5.3 & 2,705 \\
\hline $35 X-1,82-86$ & 268.67 & $11,395.3$ & 2.9 & 3,976 \\
\hline
\end{tabular}

\begin{tabular}{|c|c|c|c|c|}
\hline \multirow{2}{*}{$\begin{array}{l}\text { Core, section, } \\
\text { interval }(\mathrm{cm})\end{array}$} & \multirow{2}{*}{$\begin{array}{l}\text { Depth } \\
\text { CSF }(m)\end{array}$} & \multicolumn{2}{|c|}{ Headspace gas (ppmv) } & \multirow[b]{2}{*}{$\mathrm{C}_{1} / \mathrm{C}_{2}$} \\
\hline & & Methane & Ethane & \\
\hline $36 X-1,136.5-140.5$ & 278.72 & $6,248.9$ & 4.4 & 1,411 \\
\hline $37 X-1,137.5-141.5$ & 288.23 & $16,875.6$ & 4.8 & 3,483 \\
\hline $39 X-1,137-141$ & 307.22 & $14,871.2$ & 5.1 & 2,916 \\
\hline $40 X-1,137-141$ & 316.72 & $9,146.1$ & 4.6 & 2,007 \\
\hline $41 X-1,137.5-141.5$ & 326.23 & $12,603.1$ & 4.1 & 3,101 \\
\hline $42 X-1,135.5-139.5$ & 335.71 & $13,216.5$ & 4.4 & 2,983 \\
\hline $43 \mathrm{X}-1,137-141$ & 345.22 & $14,818.3$ & 5.1 & 2,910 \\
\hline $44 \mathrm{X}-1,138-142$ & 354.73 & $13,718.4$ & 5.8 & 2,374 \\
\hline $45 X-1,135.5-139.5$ & 364.21 & $13,194.5$ & 6.0 & 2,199 \\
\hline $46 \mathrm{X}-1,138-142$ & 373.73 & $11,021.8$ & 4.9 & 2,264 \\
\hline $47 X-1,136-140$ & 383.21 & $6,373.1$ & 3.7 & 1,701 \\
\hline $48 \mathrm{X}-1,137-141$ & 392.72 & $15,742.5$ & 6.9 & 2,274 \\
\hline $49 X-1,137-141$ & 402.22 & $5,867.8$ & 4.8 & 1,232 \\
\hline \multicolumn{5}{|l|}{ 316-C0006F- } \\
\hline 2R-1, 98-102 & 405.50 & $4,976.0$ & 2.5 & 1,964 \\
\hline $4 \mathrm{R}-1,136-140$ & 424.89 & $8,711.0$ & 2.7 & 3,169 \\
\hline $5 R-1,136-140$ & 434.40 & $8,654.5$ & 2.8 & 3,089 \\
\hline 6R-1, 137-141 & 439.39 & $3,772.9$ & 0.0 & - \\
\hline 7R-1, 137-141 & 448.89 & $7,236.0$ & 2.2 & 3,280 \\
\hline $9 R-1,146-150$ & 467.98 & $11,497.2$ & 2.7 & 4,239 \\
\hline $11 \mathrm{R}-1,146-150$ & 487.00 & $10,743.3$ & 2.7 & 3,968 \\
\hline $12 \mathrm{R}-1,139-143$ & 496.42 & $8,029.7$ & 2.5 & 3,248 \\
\hline $13 \mathrm{R}-1,136-140$ & 505.88 & $3,496.0$ & 0.0 & - \\
\hline 14R-1, 146.5-150.5 & 515.49 & $7,471.0$ & 2.9 & 2,578 \\
\hline $15 \mathrm{R}-1,146-150$ & 524.98 & $4,585.3$ & 2.4 & 1,884 \\
\hline 16R-1, 137-141 & 534.39 & $11,021.8$ & 5.6 & 1,980 \\
\hline 17R-1, 133.5-137.5 & 543.86 & $4,013.9$ & 2.5 & 1,624 \\
\hline $18 \mathrm{R}-1,135-139$ & 553.37 & $10,666.8$ & 5.7 & 1,879 \\
\hline $19 \mathrm{R}-1,136-140$ & 562.88 & $2,456.1$ & 1.9 & 1,261 \\
\hline 20R-1, 137-141 & 572.39 & $3,755.5$ & 2.5 & 1,525 \\
\hline $22 \mathrm{R}-1,41.5-45.5$ & 591.40 & $2,614.3$ & 2.0 & 1,334 \\
\hline
\end{tabular}

Notes: $\mathrm{CSF}=$ core depth below seafloor. $-=$ not applicable . 
Table T16. Hydrocarbon gas concentration from additional headspace gas analysis, Site C0006. (See table notes.) (Continued on next page.)

\begin{tabular}{|c|c|c|c|c|c|c|}
\hline \multirow{2}{*}{$\begin{array}{l}\text { Core, section, } \\
\text { interval }(\mathrm{cm})\end{array}$} & \multirow{2}{*}{$\begin{array}{l}\text { Depth } \\
\text { CSF }(m)\end{array}$} & \multicolumn{2}{|c|}{ Headspace gas (ppmv) } & \multirow[b]{2}{*}{$\mathrm{C}_{1} / \mathrm{C}_{2}$} & \multicolumn{2}{|c|}{ Headspace gas $(\mu \mathrm{M})$} \\
\hline & & Methane & Ethane & & Methane & Ethane \\
\hline \multicolumn{7}{|l|}{ 316-C0006C- } \\
\hline $1 \mathrm{H}-1,119-123$ & 1.19 & $21,907.5$ & 0.0 & - & 5,061 & 0.00 \\
\hline $1 \mathrm{H}-5,145-149$ & 5.91 & $11,880.4$ & 0.0 & - & 5,260 & 0.00 \\
\hline 316-C0006D- & & & & & & \\
\hline $1 \mathrm{H}-1,117-121$ & 1.17 & 52.3 & 0.0 & - & 11.0 & 0.00 \\
\hline $1 \mathrm{H}-4,116.5-120.5$ & 4.00 & $21,288.0$ & 0.0 & - & 5,173 & 0.00 \\
\hline \multicolumn{7}{|l|}{ 316-C0006E- } \\
\hline $1 \mathrm{H}-1,116.5-120.5$ & 1.19 & 29.7 & 0.0 & - & 5.7 & 0.00 \\
\hline $1 \mathrm{H}-4,137-141$ & 4.22 & 106.1 & 0.0 & - & 24.7 & 0.00 \\
\hline $2 \mathrm{H}-2,115.5-119.5$ & 7.77 & 202.1 & 0.0 & - & 45.1 & 0.00 \\
\hline $2 \mathrm{H}-6,117-121$ & 12.07 & $23,883.0$ & 0.0 & - & 5,455 & 0.00 \\
\hline $2 \mathrm{H}-8,143.5-147.5$ & 13.78 & $22,839.9$ & 0.0 & - & 6,435 & 0.00 \\
\hline $3 \mathrm{H}-2,115-119$ & 17.27 & $16,939.5$ & 0.0 & - & 6,075 & 0.00 \\
\hline $3 \mathrm{H}-6,118.5-122.5$ & 21.64 & $10,543.9$ & 0.0 & - & 3,832 & 0.00 \\
\hline $3 \mathrm{H}-9,147-151$ & 24.79 & $4,745.0$ & 0.0 & - & 2,139 & 0.00 \\
\hline $4 \mathrm{H}-4,144-148$ & 29.90 & $7,343.8$ & 0.0 & - & 2,029 & 0.00 \\
\hline $4 \mathrm{H}-6,132.5-136.5$ & 31.50 & $12,054.6$ & 0.0 & - & 3,094 & 0.00 \\
\hline $5 \mathrm{H}-4,140.5-144.5$ & 37.48 & $7,499.7$ & 0.0 & - & 2,264 & 0.00 \\
\hline $5 \mathrm{H}-2,115-119$ & 35.82 & $17,520.6$ & 0.0 & - & 4,285 & 0.00 \\
\hline 7H-1, 136.5-140.5 & 40.08 & $24,332.3$ & 0.0 & - & 6,001 & 0.00 \\
\hline 7H-3, 137-141 & 42.90 & $19,973.1$ & 0.0 & - & 5,704 & 0.00 \\
\hline $8 \mathrm{H}-1,135.5-139.5$ & 49.57 & $14,912.1$ & 0.0 & - & 4,499 & 0.00 \\
\hline $8 \mathrm{H}-3,74-78$ & 51.77 & $13,847.4$ & 0.0 & - & 4,010 & 0.00 \\
\hline $9 \mathrm{H}-3,0-4$ & 60.51 & $8,220.7$ & 0.0 & - & 2,933 & 0.00 \\
\hline $9 \mathrm{H}-4,129-133$ & 62.38 & $11,637.2$ & 0.0 & - & 3,057 & 0.00 \\
\hline $10 \mathrm{H}-4,0-4$ & 64.53 & $10,320.9$ & 0.0 & - & 3,711 & 0.00 \\
\hline $11 \mathrm{H}-3,72.4-76.4$ & 67.68 & $17,734.9$ & 0.0 & - & 4,579 & 0.00 \\
\hline $11 \mathrm{H}-6,137.5-141.5$ & 70.30 & $16,769.0$ & 0.0 & - & 4,641 & 0.00 \\
\hline $12 \mathrm{H}-3,137-141$ & 73.70 & $7,139.4$ & 0.0 & - & 3,127 & 0.00 \\
\hline $12 \mathrm{H}-5,137-141$ & 76.29 & $21,160.0$ & 2.7 & 7,913 & 7,554 & 0.95 \\
\hline $15 X-1,137-141$ & 80.72 & $14,472.0$ & 0.0 & - & 4,835 & 0.00 \\
\hline $15 X-6,137-141$ & 83.36 & $27,384.3$ & 6.3 & 4,340 & 8,433 & 1.94 \\
\hline $16 \mathrm{X}-1,124-128$ & 90.09 & $21,578.3$ & 2.6 & 8,153 & 6,370 & 0.78 \\
\hline $17 X-2,52-56$ & 100.28 & $27,237.1$ & 4.2 & 6,457 & 10,934 & 1.69 \\
\hline $18 X-1,133-137$ & 107.68 & $17,538.6$ & 3.4 & 5,091 & 5,806 & 1.14 \\
\hline $19 X-1,105-109$ & 116.90 & $12,035.7$ & 2.6 & 4,639 & 3,837 & 0.83 \\
\hline $19 X-5,28.5-32.5$ & 120.06 & $17,377.5$ & 2.8 & 6,235 & 4,719 & 0.76 \\
\hline $20 X-3,139-143$ & 129.57 & $13,101.4$ & 3.4 & 3,873 & 3,308 & 0.85 \\
\hline $20 X-6,39-43$ & 132.83 & $16,051.8$ & 2.6 & 6,179 & 5,009 & 0.81 \\
\hline $21 X-2,106-110$ & 137.36 & $7,399.8$ & 2.3 & 3,282 & 3,156 & 0.96 \\
\hline $22 X-2,105-109$ & 146.81 & $4,260.0$ & 0.0 & - & 2,225 & 0.00 \\
\hline $22 X-5,137-141$ & 149.98 & $6,549.7$ & 3.0 & 2,211 & 2,255 & 1.02 \\
\hline $23 X-3,105.5-109.5$ & 157.72 & $10,014.7$ & 2.2 & 4,546 & 3,100 & 0.68 \\
\hline $23 X-5,137-141$ & 159.47 & $12,251.1$ & 1.9 & 6,535 & 5,362 & 0.82 \\
\hline $24 X-1,0-5$ & 164.47 & $4,695.8$ & 2.5 & 1,886 & 2,913 & 1.54 \\
\hline $25 X-4,136.7-140.7$ & 178.44 & $9,846.7$ & 2.4 & 4,030 & 3,941 & 0.98 \\
\hline $25 X-6,88-92$ & 180.77 & $9,902.0$ & 4.1 & 2,440 & 3,285 & 1.35 \\
\hline $26 X-5,0-4$ & 186.98 & $16,277.1$ & 4.1 & 3,987 & 6,373 & 1.60 \\
\hline $26 X-7,137.5-141.5$ & 190.86 & $9,498.2$ & 3.1 & 3,025 & 4,688 & 1.55 \\
\hline $27 X-2,137.5-141.5$ & 194.64 & $12,639.8$ & 3.0 & 4,262 & 4,171 & 0.98 \\
\hline $27 X-4,137-141$ & 197.47 & $8,246.1$ & 4.7 & 1,759 & 3,366 & 1.91 \\
\hline $28 X-2,102.5-106.5$ & 203.79 & $8,026.7$ & 3.9 & 2,073 & 2,638 & 1.27 \\
\hline 29X-3, 137-141 & 215.06 & $5,633.7$ & 2.1 & 2,693 & 2,386 & 0.89 \\
\hline 29X-6, 105-109 & 219.02 & $9,924.8$ & 3.9 & 2,540 & 3,538 & 1.39 \\
\hline $30 X-2,137.5-141.5$ & 223.14 & $4,561.7$ & 0.0 & - & 2,894 & 0.00 \\
\hline $30 X-5,137-141$ & 225.97 & $9,971.6$ & 3.6 & 2,755 & 3,948 & 1.43 \\
\hline $31 X-2,101-105$ & 232.30 & $11,540.2$ & 4.4 & 2,597 & 4,107 & 1.58 \\
\hline $32 X-6,137-141$ & 246.40 & $4,251.5$ & 2.1 & 2,045 & 3,276 & 1.60 \\
\hline $34 X-2,137-141$ & 261.13 & $10,089.7$ & 3.8 & 2,671 & 2,415 & 0.90 \\
\hline $34 X-4,100.5-104.4$ & 263.59 & $9,346.7$ & 4.6 & 2,045 & 2,006 & 0.98 \\
\hline $34 \mathrm{X}-6,137-141$ & 265.39 & $7,037.2$ & 3.8 & 1,832 & 2,211 & 1.21 \\
\hline $35 X-1,82-86$ & 268.67 & $13,539.7$ & 3.6 & 3,745 & 4,598 & 1.23 \\
\hline $35 X-3,136.5-140.5$ & 270.44 & $6,425.6$ & 3.9 & 1,631 & 3,489 & 2.14 \\
\hline $36 X-3,137-141$ & 281.54 & $14,284.5$ & 5.3 & 2,693 & 5,149 & 1.91 \\
\hline $36 \mathrm{X}-6,138-142$ & 284.36 & $7,907.9$ & 4.0 & 1,979 & 4,709 & 2.38 \\
\hline $37 X-4,101-105$ & 292.10 & $13,934.6$ & 5.0 & 2,811 & 6,065 & 2.16 \\
\hline
\end{tabular}


Table T16 (continued).

\begin{tabular}{|c|c|c|c|c|c|c|}
\hline \multirow{2}{*}{$\begin{array}{l}\text { Core, section, } \\
\text { interval }(\mathrm{cm})\end{array}$} & \multirow{2}{*}{$\begin{array}{l}\text { Depth } \\
\text { CSF (m) }\end{array}$} & \multicolumn{2}{|c|}{ Headspace gas (ppmv) } & \multirow[b]{2}{*}{$\mathrm{C}_{1} / \mathrm{C}_{2}$} & \multicolumn{2}{|c|}{ Headspace gas $(\mu \mathrm{M})$} \\
\hline & & Methane & Ethane & & Methane & Ethane \\
\hline $39 X-3,99.5-103.5$ & 309.67 & $16,369.8$ & 3.6 & 4,576 & 12,611 & 2.76 \\
\hline $39 X-6,137-141$ & 312.87 & $7,292.3$ & 3.5 & 2,065 & 2,596 & 1.26 \\
\hline $40 X-4,98.5-102.5$ & 320.57 & $8,756.7$ & 4.7 & 1,861 & 4,376 & 2.35 \\
\hline $40 X-6,98-102$ & 321.99 & $9,787.3$ & 4.2 & 2,310 & 4,476 & 1.94 \\
\hline $40 X-8,131-135$ & 323.74 & $4,617.2$ & 3.8 & 1,217 & 1,776 & 1.46 \\
\hline $41 X-3,113.5-117.5$ & 328.81 & $9,981.8$ & 4.1 & 2,411 & 3,548 & 1.47 \\
\hline $41 X-5,122.3-126.3$ & 330.45 & $14,518.2$ & 5.0 & 2,920 & 4,005 & 1.37 \\
\hline $42 X-2,138-142$ & 337.13 & $17,148.4$ & 5.9 & 2,902 & 4,109 & 1.42 \\
\hline $42 X-4,98.5-102.5$ & 339.56 & $8,541.3$ & 3.9 & 2,174 & 2,033 & 1.05 \\
\hline $42 X-7,137-141$ & 342.77 & $9,216.8$ & 4.3 & 2,127 & 2,617 & 1.38 \\
\hline $43 X-1,137-141$ & 345.22 & $8,328.1$ & 4.0 & 2,088 & 2,753 & 1.47 \\
\hline $43 X-4,100.5-104.5$ & 349.09 & $6,717.5$ & 3.7 & 1,797 & 1,682 & 1.04 \\
\hline $44 X-2,137.5-141.5$ & 356.15 & $8,110.9$ & 2.7 & 2,950 & 3,376 & 1.27 \\
\hline $44 X-4,137.5-141.5$ & 358.97 & $10,146.4$ & 3.9 & 2,573 & 3,961 & 1.71 \\
\hline $45 X-3,99-103$ & 366.64 & $9,002.4$ & 4.6 & 1,945 & 3,276 & 1.87 \\
\hline $45 X-7,138-142$ & 371.28 & $10,490.3$ & 5.4 & 1,946 & 3,480 & 1.99 \\
\hline $46 X-2,137.5-141.5$ & 375.15 & $19,443.5$ & 7.4 & 2,616 & 4,862 & 2.08 \\
\hline $46 X-4,99-103$ & 377.58 & $5,472.2$ & 4.0 & 1,379 & 1,680 & 1.36 \\
\hline $47 X-5,34-38$ & 387.08 & $9,345.1$ & 3.8 & 2,470 & 3,784 & 1.70 \\
\hline $47 X-8,137.5-141.5$ & 390.30 & $5,263.2$ & 2.8 & 1,877 & 1,299 & 0.78 \\
\hline $48 X-4,136.5-140.5$ & 396.96 & $7,693.9$ & 3.9 & 1,993 & 3,386 & 1.88 \\
\hline $49 X-3,99-103$ & 404.66 & $9,805.1$ & 5.3 & 1,838 & 1,890 & 1.17 \\
\hline $49 X-6,59.5-63.5$ & 406.72 & $7,848.9$ & 4.0 & 1,976 & 2,240 & 1.27 \\
\hline \multicolumn{7}{|l|}{ 316-C0006F- } \\
\hline 2R-1, 98-102 & 405.50 & $6,563.5$ & 3.8 & 1,736 & 2,658 & 1.53 \\
\hline $4 R-1,136-140$ & 426.29 & $8,363.1$ & 2.9 & 2,854 & 3,164 & 1.11 \\
\hline $5 R-1,136-140$ & 434.38 & $6,721.3$ & 2.6 & 2,539 & 3,890 & 1.53 \\
\hline $6 \mathrm{R}-1,137-141$ & 439.39 & $4,402.6$ & 0.0 & - & 1,867 & 0.00 \\
\hline 7R-1, 137-141 & 448.89 & $9,475.0$ & 2.9 & 3,217 & 2,282 & 0.71 \\
\hline $8 R-1,137-141$ & 458.39 & $9,287.2$ & 2.9 & 3,216 & 2,159 & 0.67 \\
\hline $9 R-1,146-150$ & 467.98 & $4,317.3$ & 1.7 & 2,510 & 1,172 & 0.47 \\
\hline $11 R-1,146-150$ & 486.98 & $10,397.0$ & 2.7 & 3,904 & 3,538 & 0.91 \\
\hline 12R-1, 139-143 & 496.41 & $12,133.7$ & 3.5 & 3,503 & 3,575 & 1.02 \\
\hline $13 R-1,136-140$ & 505.88 & $3,933.7$ & 0.0 & - & 2,326 & 0.00 \\
\hline $14 \mathrm{R}-1,146.5-150.5$ & 515.49 & $3,676.0$ & 3.6 & 1,008 & 2,194 & 2.18 \\
\hline $15 R-1,146-150$ & 524.98 & $8,299.7$ & 7.8 & 1,058 & 2,492 & 2.35 \\
\hline $15 R-2,99-103$ & 526.01 & $6,897.3$ & 4.1 & 1,672 & 1,640 & 0.98 \\
\hline 16R-1, 137-141 & 534.39 & $9,614.0$ & 6.2 & 1,546 & 2,207 & 1.43 \\
\hline 17R-1, 133.5-137.5 & 543.86 & $5,512.5$ & 4.3 & 1,283 & 1,500 & 1.17 \\
\hline 18R-1, 135-139 & 553.37 & $10,094.8$ & 5.4 & 1,877 & 3,918 & 2.09 \\
\hline $19 R-1,136-140$ & 562.88 & $5,680.1$ & 4.7 & 1,221 & 1,610 & 1.32 \\
\hline 20R-1, 137-141 & 572.39 & $6,602.8$ & 4.5 & 1,463 & 1,844 & 1.26 \\
\hline $21 \mathrm{R}-\mathrm{CC}, 0-5$ & 580.53 & $8,323.7$ & 5.2 & 1,599 & 2,393 & 1.50 \\
\hline $22 \mathrm{R}-2,38-42$ & 591.82 & $6,648.5$ & 4.0 & 1,666 & 1,364 & 0.82 \\
\hline
\end{tabular}

Notes: CSF $=$ core depth below seafloor. $-=$ not applicable. 
Table T17. Carbonate, carbon, nitrogen, and sulfur in sediments, Site C0006. (See table notes.) (Continued on next page.)

\begin{tabular}{|c|c|c|c|c|c|c|}
\hline $\begin{array}{l}\text { Core, section, } \\
\text { interval }(\mathrm{cm})\end{array}$ & $\begin{array}{l}\text { Depth } \\
\text { CSF (m) }\end{array}$ & $\begin{array}{l}\mathrm{CaCO}_{3} \\
\text { (wt\%) }\end{array}$ & $\begin{array}{c}\text { TOC } \\
\text { (wt\%) }\end{array}$ & $\begin{array}{c}\mathrm{TN} \\
(\mathrm{wt} \%)\end{array}$ & $\mathrm{C} / \mathrm{N}$ & $\begin{array}{c}\text { TS } \\
\text { (wt\%) }\end{array}$ \\
\hline \multicolumn{7}{|l|}{ 316-C0006C- } \\
\hline $1 \mathrm{H}-2,0-1.5$ & 1.27 & 5.83 & 0.41 & 0.05 & 7.67 & 0.37 \\
\hline $1 \mathrm{H}-6,0-1.5$ & 5.98 & 2.34 & 0.35 & 0.05 & 7.70 & 0.43 \\
\hline \multicolumn{7}{|l|}{ 316-C0006D- } \\
\hline $1 \mathrm{H}-2,0-1.5$ & 1.22 & 2.59 & 0.19 & 0.04 & 4.92 & 0.67 \\
\hline $1 \mathrm{H}-2,20-21.5$ & 1.42 & 2.06 & 0.40 & 0.04 & 9.97 & 0.81 \\
\hline $1 \mathrm{H}-5,0-1.5$ & 4.05 & 4.24 & 0.49 & 0.05 & 8.94 & 0.34 \\
\hline \multicolumn{7}{|l|}{ 316-C0006E- } \\
\hline $1 \mathrm{H}-2,0-1.5$ & 1.21 & 1.07 & 0.52 & 0.05 & 10.57 & 0.66 \\
\hline $1 \mathrm{H}-4,69.5-71$ & 3.53 & 1.01 & 0.43 & 0.04 & 9.67 & 0.68 \\
\hline $1 \mathrm{H}-5,0-1.5$ & 4.25 & 0.32 & 0.21 & 0.03 & 7.65 & 0.47 \\
\hline $1 \mathrm{H}-6,49.5-51$ & 4.97 & 4.64 & 0.62 & 0.05 & 11.69 & 0.53 \\
\hline $2 \mathrm{H}-3,0-1.5$ & 7.80 & 2.50 & 0.50 & 0.05 & 10.42 & 0.50 \\
\hline $2 \mathrm{H}-4,115.5-117$ & 9.18 & 5.59 & 0.56 & 0.05 & 11.20 & 0.34 \\
\hline $2 \mathrm{H}-7,0-1.5$ & 12.09 & 5.06 & 0.45 & 0.05 & 8.98 & 0.36 \\
\hline $3 \mathrm{H}-3,0-1.5$ & 17.29 & 0.72 & 0.31 & 0.03 & 9.52 & 1.75 \\
\hline $3 \mathrm{H}-6,55-56.5$ & 20.99 & 2.65 & 0.33 & 0.05 & 6.70 & 0.06 \\
\hline $3 \mathrm{H}-6,95-96.5$ & 21.39 & 6.15 & 0.62 & 0.06 & 11.01 & 0.14 \\
\hline $3 \mathrm{H}-7,0-1.5$ & 21.66 & 0.16 & 0.28 & 0.03 & 9.07 & 0.58 \\
\hline $4 \mathrm{H}-4,29.5-31$ & 28.74 & 1.86 & 0.49 & 0.04 & 10.96 & 0.12 \\
\hline $4 \mathrm{H}-5,0-1.5$ & 29.93 & 1.35 & 0.34 & 0.04 & 8.32 & 0.11 \\
\hline $5 \mathrm{H}-1,126.5-128$ & 34.49 & 0.92 & 0.44 & 0.06 & 7.40 & 0.09 \\
\hline $5 \mathrm{H}-3,0-1.5$ & 35.85 & 0.78 & 0.25 & 0.03 & 9.67 & 0.12 \\
\hline $5 \mathrm{H}-4,20-21.5$ & 36.26 & 1.00 & 0.25 & 0.03 & 7.40 & 0.19 \\
\hline $5 \mathrm{H}-5,70-71.5$ & 38.21 & 0.63 & 0.19 & 0.02 & 9.69 & 0.12 \\
\hline 7H-2, 115.5-117 & 41.26 & 0.79 & 0.22 & 0.03 & 6.47 & 0.16 \\
\hline $7 \mathrm{H}-4,0-1.5$ & 42.92 & 0.63 & 0.13 & 0.02 & 5.51 & 0.07 \\
\hline $7 \mathrm{H}-4,20.5-22$ & 43.13 & 0.76 & 0.15 & 0.02 & 7.81 & 0.13 \\
\hline $8 \mathrm{H}-1,55-56.5$ & 48.75 & 3.84 & 0.45 & 0.05 & 8.73 & 0.06 \\
\hline $8 \mathrm{H}-2,86.5-88$ & 50.46 & 0.74 & 0.12 & 0.02 & 5.38 & 0.09 \\
\hline $8 \mathrm{H}-4,0-1.5$ & 51.80 & 1.76 & 0.39 & 0.04 & 9.98 & 0.12 \\
\hline $9 \mathrm{H}-2,93-94.5$ & 60.04 & 1.21 & 0.35 & 0.05 & 7.68 & 0.08 \\
\hline $9 \mathrm{H}-5,0-1.5$ & 62.42 & 0.90 & 0.25 & 0.03 & 8.54 & 0.14 \\
\hline $10 \mathrm{H}-8,0-1.5$ & 64.52 & 0.84 & 0.26 & 0.03 & 8.99 & 0.40 \\
\hline $11 \mathrm{H}-1,79-81$ & 65.47 & 0.64 & 0.34 & 0.05 & 6.84 & 0.07 \\
\hline $11 \mathrm{H}-4,0-1.5$ & 67.71 & 0.93 & 0.23 & 0.03 & 7.49 & 0.22 \\
\hline $12 \mathrm{H}-6,0-1.5$ & 76.31 & 0.95 & 0.42 & 0.05 & 8.91 & 0.20 \\
\hline $15 X-4,0-1.5$ & 81.77 & 1.01 & 0.28 & 0.04 & 6.92 & 0.25 \\
\hline $16 X-1,96.5-98$ & 89.80 & 0.77 & 0.25 & 0.03 & 8.00 & 0.20 \\
\hline $16 X-2,0-1.5$ & 90.12 & 1.20 & 0.34 & 0.04 & 7.91 & 0.15 \\
\hline $17 X-1,115.5-117$ & 99.49 & 0.43 & 0.31 & 0.05 & 6.66 & 0.07 \\
\hline $17 X-3,0-1.5$ & 100.31 & 0.66 & 0.33 & 0.03 & 9.88 & 0.16 \\
\hline $17 X-5,27.5-29$ & 101.46 & 2.67 & 0.86 & 0.05 & 16.85 & 0.31 \\
\hline $19 X-3,113.5-115$ & 118.40 & 0.94 & 0.47 & 0.04 & 10.87 & 0.30 \\
\hline $19 X-4,95.5-97$ & 119.63 & 0.29 & 0.41 & 0.05 & 7.81 & 0.11 \\
\hline $19 X-5,0-1.5$ & 119.76 & 2.48 & 0.50 & 0.06 & 8.82 & 0.15 \\
\hline $19 X-6,39-40.5$ & 120.48 & 1.71 & 0.41 & 0.06 & 7.21 & 0.18 \\
\hline $20 X-1,38.5-40$ & 125.72 & 0.95 & 0.29 & 0.03 & 8.45 & 0.29 \\
\hline $20 X-1,118.5-120$ & 126.52 & 0.40 & 0.36 & 0.05 & 7.63 & 0.08 \\
\hline $20 X-2,121.5-123$ & 127.97 & 1.63 & 0.58 & 0.07 & 8.38 & 0.13 \\
\hline $20 X-3,0-1.5$ & 128.17 & 1.85 & 0.53 & 0.07 & 7.88 & 0.24 \\
\hline $20 X-5,33.5-35$ & 131.35 & 2.66 & 0.50 & 0.07 & 7.59 & 0.11 \\
\hline $20 X-5,108-109.5$ & 132.09 & 2.21 & 0.42 & 0.05 & 7.79 & 0.17 \\
\hline $20 X-7,0-1.5$ & 132.85 & 1.29 & 0.14 & 0.03 & 4.86 & 0.09 \\
\hline $21 X-3,0-1.5$ & 137.39 & 1.69 & 0.38 & 0.05 & 8.47 & 0.16 \\
\hline $22 X-2,33-34.5$ & 146.08 & 2.17 & 0.38 & 0.05 & 7.81 & 0.15 \\
\hline $22 X-3,0-1.5$ & 146.84 & 2.37 & 0.39 & 0.05 & 7.77 & 0.12 \\
\hline $22 X-4,30-31.5$ & 147.48 & 2.88 & 0.59 & 0.07 & 8.87 & 0.11 \\
\hline $22 X-4,115-116.5$ & 148.33 & 1.36 & 0.39 & 0.04 & 9.42 & 0.16 \\
\hline $22 X-6,20-21.5$ & 150.20 & 1.55 & 0.34 & 0.04 & 9.25 & 0.15 \\
\hline $22 X-6,66-67.5$ & 150.66 & 0.99 & 0.33 & 0.04 & 8.76 & 0.11 \\
\hline $23 X-1,65-66.5$ & 154.49 & 3.21 & 0.49 & 0.06 & 7.85 & 0.11 \\
\hline $23 X-1,101-102.5$ & 154.85 & 1.55 & 0.30 & 0.04 & 7.93 & 0.10 \\
\hline $23 X-3,26-27.5$ & 156.91 & 0.99 & 0.24 & 0.04 & 6.57 & 0.14 \\
\hline $23 X-3,67-68.5$ & 157.32 & 1.97 & 0.43 & 0.06 & 7.12 & 0.06 \\
\hline $23 X-4,0-1.5$ & 157.75 & 2.89 & 0.47 & 0.06 & 7.59 & 0.11 \\
\hline $23 X-5,90-91.5$ & 158.98 & 1.75 & 0.35 & 0.05 & 7.57 & 0.08 \\
\hline
\end{tabular}

\begin{tabular}{|c|c|c|c|c|c|c|}
\hline $\begin{array}{l}\text { Core, section, } \\
\text { interval }(\mathrm{cm})\end{array}$ & $\begin{array}{l}\text { Depth } \\
\text { CSF (m) }\end{array}$ & $\begin{array}{l}\mathrm{CaCO}_{3} \\
\text { (wt\%) }\end{array}$ & $\begin{array}{c}\text { TOC } \\
\text { (wt\%) }\end{array}$ & $\begin{array}{c}\mathrm{TN} \\
(w t \%)\end{array}$ & $\mathrm{C} / \mathrm{N}$ & $\begin{array}{c}\text { TS } \\
\text { (wt\%) }\end{array}$ \\
\hline $25 X-6,25-26.5$ & 180.12 & 1.88 & 0.35 & 0.05 & 7.68 & 0.15 \\
\hline $25 X-7,0-1.5$ & 180.79 & 0.76 & 0.22 & 0.03 & 7.51 & 0.15 \\
\hline $26 X-1,147.5-149$ & 183.81 & 1.86 & 0.53 & 0.06 & 9.60 & 0.18 \\
\hline $26 X-4,0-1.5$ & 186.65 & 2.19 & 0.41 & 0.06 & 7.16 & 0.08 \\
\hline $26 X-8,94.5-96$ & 191.83 & 1.65 & 0.35 & 0.05 & 7.59 & 0.86 \\
\hline $27 X-1,60-61.5$ & 192.44 & 3.05 & 0.59 & 0.06 & 9.62 & 0.15 \\
\hline $27 X-5,16.5-18$ & 197.66 & 0.90 & 0.26 & 0.04 & 7.24 & 0.12 \\
\hline $27 X-8,30-31.5$ & 200.62 & 0.74 & 0.16 & 0.03 & 4.95 & 0.11 \\
\hline $28 X-1,31-32.5$ & 201.65 & 2.43 & 0.39 & 0.06 & 6.74 & 0.11 \\
\hline $28 X-1,91-92.5$ & 202.25 & 1.76 & 0.33 & 0.05 & 7.29 & 0.10 \\
\hline $28 X-3,0-1.5$ & 203.81 & 0.84 & 0.30 & 0.04 & 7.39 & 0.18 \\
\hline $28 X-4,75-76.5$ & 204.92 & 1.09 & 0.30 & 0.04 & 7.48 & 0.10 \\
\hline $29 X-2,84.5-86$ & 213.11 & 2.72 & 0.48 & 0.05 & 8.90 & 0.10 \\
\hline $29 X-7,0-1.5$ & 219.05 & 2.17 & 0.51 & 0.06 & 8.45 & 0.14 \\
\hline $30 X-1,107-108.5$ & 221.41 & 1.51 & 0.42 & 0.06 & 7.22 & 0.16 \\
\hline $30 X-3,0-1.5$ & 223.16 & 1.04 & 0.41 & 0.07 & 6.22 & 0.05 \\
\hline $30 X-8,80.5-82$ & 229.64 & 2.50 & 0.44 & 0.06 & 7.23 & 0.05 \\
\hline $31 X-3,0-1.5$ & 232.33 & 1.24 & 0.10 & 0.03 & 3.82 & 0.09 \\
\hline $31 X-4,65-66.5$ & 233.34 & 1.79 & 0.39 & 0.05 & 7.36 & 0.28 \\
\hline $32 X-4,0-1.5$ & 243.22 & 3.09 & 0.71 & 0.07 & 9.53 & 0.26 \\
\hline $32 X-5,23-24.5$ & 243.83 & 1.27 & 0.44 & 0.07 & 6.61 & 0.15 \\
\hline $32 X-5,91.5-93$ & 244.51 & 0.92 & 0.40 & 0.05 & 7.47 & 0.20 \\
\hline $32 X-6,18.5-20$ & 245.20 & 2.17 & 0.50 & 0.05 & 9.09 & 0.21 \\
\hline $34 X-3,94-95.5$ & 262.10 & 1.68 & 0.39 & 0.05 & 7.24 & 0.15 \\
\hline $34 X-4,44-45.5$ & 263.02 & 2.56 & 0.44 & 0.05 & 8.77 & 0.16 \\
\hline $34 X-5,0-1.5$ & 263.62 & 1.79 & 0.40 & 0.05 & 7.61 & 0.08 \\
\hline $35 X-2,0-1.5$ & 268.70 & 2.06 & 0.17 & 0.03 & 5.19 & 0.13 \\
\hline $35 X-3,118-119.5$ & 270.24 & 1.99 & 0.39 & 0.04 & 9.12 & 0.08 \\
\hline $35 X-4,10-11.5$ & 270.57 & 2.24 & 0.39 & 0.05 & 7.70 & 0.07 \\
\hline $36 X-1,100-101.5$ & 278.34 & 2.31 & 0.44 & 0.05 & 8.70 & 0.11 \\
\hline $36 X-4,0-1.5$ & 281.56 & 2.22 & 0.55 & 0.07 & 8.05 & 0.16 \\
\hline $37 X-2,78.5-80$ & 289.04 & 2.94 & 0.54 & 0.07 & 8.17 & 0.08 \\
\hline $37 X-4,18.5-20$ & 291.26 & 2.01 & 0.47 & 0.05 & 9.51 & 0.19 \\
\hline $37 X-4,58-59.5$ & 291.65 & 0.52 & 0.48 & 0.07 & 7.18 & 0.07 \\
\hline $37 X-5,0-1.5$ & 292.12 & 1.68 & 0.40 & 0.05 & 8.63 & 0.15 \\
\hline $38 X-2,0-1.5$ & 296.70 & 0.43 & 0.30 & 0.04 & 6.84 & 0.10 \\
\hline $39 X-3,71-72.5$ & 309.37 & 0.94 & 0.37 & 0.06 & 6.60 & 0.08 \\
\hline $39 X-4,0-1.5$ & 309.69 & 2.73 & 0.53 & 0.05 & 10.27 & 0.16 \\
\hline $39 X-C C, 31-33$ & 315.67 & 2.75 & 0.44 & 0.05 & 8.73 & 0.22 \\
\hline $40 X-7,0-1.5$ & 322.02 & 1.58 & 0.43 & 0.05 & 7.88 & 0.21 \\
\hline $40 X-8,60-61.5$ & 323.02 & 2.57 & 0.14 & 0.05 & 3.02 & 0.18 \\
\hline $41 X-4,0-1.5$ & 328.83 & 1.12 & 0.82 & 0.07 & 12.09 & 0.11 \\
\hline $42 X-5,0-1.5$ & 339.58 & 5.02 & 0.36 & 0.05 & 7.41 & 0.14 \\
\hline $42 X-8,56.5-58$ & 343.36 & 4.69 & 0.35 & 0.05 & 6.46 & 0.13 \\
\hline $43 X-5,0-1.5$ & 349.12 & 2.55 & 0.41 & 0.05 & 8.27 & 0.11 \\
\hline $44 X-5,0-1.5$ & 359.00 & 1.75 & 0.44 & 0.05 & 8.22 & 0.10 \\
\hline $45 X-1,37.5-39$ & 363.21 & 2.27 & 0.51 & 0.05 & 10.23 & 0.15 \\
\hline $45 X-3,63.5-65$ & 366.27 & 3.35 & 0.63 & 0.06 & 9.65 & 0.20 \\
\hline $45 X-3,81.5-83$ & 366.45 & 1.19 & 0.41 & 0.05 & 7.93 & 0.13 \\
\hline $45 X-4,0-1.5$ & 366.67 & 2.27 & 0.47 & 0.06 & 8.47 & 0.14 \\
\hline $45 X-7,30-31$ & 370.18 & 1.24 & 3.80 & 0.10 & 38.08 & 1.80 \\
\hline $45 X-7,79-80$ & 370.67 & 1.45 & 6.87 & 0.15 & 46.14 & 2.66 \\
\hline $45 X-7,117-118$ & 371.05 & 1.20 & 3.91 & 0.10 & 37.31 & 2.32 \\
\hline $46 X-3,138-140$ & 376.56 & 1.74 & 0.37 & 0.04 & 8.18 & 0.18 \\
\hline $46 X-5,0-1.5$ & 377.61 & 1.25 & 0.27 & 0.04 & 6.28 & 0.18 \\
\hline $47 X-3,93-94.5$ & 385.58 & 4.39 & 0.41 & 0.05 & 8.25 & 0.10 \\
\hline $47 X-4,14.5-16$ & 386.21 & 6.48 & 0.37 & 0.06 & 6.71 & 0.09 \\
\hline $47 X-5,0-1.5$ & 386.73 & 2.13 & 0.33 & 0.05 & 6.35 & 0.10 \\
\hline $48 X-5,0-1.5$ & 396.99 & 1.81 & 0.27 & 0.04 & 6.76 & 0.08 \\
\hline $49 X-4,0-1.5$ & 404.69 & 0.98 & 0.30 & 0.04 & 6.99 & 0.21 \\
\hline \multicolumn{7}{|l|}{ 316-C0006F- } \\
\hline $2 \mathrm{R}-2,0-1.5$ & 405.53 & 2.10 & 0.33 & 0.05 & 6.36 & 0.06 \\
\hline $3 R-1,0-1.5$ & 414.01 & 2.27 & 0.33 & 0.06 & 5.68 & 0.04 \\
\hline $4 R-2,33-34.5$ & 425.24 & 2.48 & 0.30 & 0.06 & 5.17 & 0.48 \\
\hline 5R-1, 117-118.5 & 434.18 & 1.04 & 0.36 & 0.05 & 7.60 & 0.14 \\
\hline $6 \mathrm{R}-1,120-121.5$ & 439.21 & 5.80 & 0.31 & 0.05 & 5.99 & 0.07 \\
\hline 7R-1, 90-91.5 & 448.41 & 7.87 & 0.25 & 0.04 & 5.69 & 0.10 \\
\hline
\end{tabular}


Table T17 (continued).

\begin{tabular}{|c|c|c|c|c|c|c|}
\hline $\begin{array}{l}\text { Core, section, } \\
\text { interval }(\mathrm{cm})\end{array}$ & $\begin{array}{l}\text { Depth } \\
\text { CSF (m) }\end{array}$ & $\begin{array}{l}\mathrm{CaCO}_{3} \\
(\mathrm{wt} \%)\end{array}$ & $\begin{array}{l}\text { TOC } \\
\text { (wt\%) }\end{array}$ & $\begin{array}{c}\text { TN } \\
(w t \%)\end{array}$ & $\mathrm{C} / \mathrm{N}$ & $\begin{array}{c}\text { TS } \\
\text { (wt\%) }\end{array}$ \\
\hline $8 R-1,12.5-14$ & 457.13 & 0.33 & 0.44 & 0.07 & 6.55 & 0.15 \\
\hline 8R-1, 103-104.5 & 458.04 & 0.27 & 0.44 & 0.07 & 6.39 & 0.24 \\
\hline $8 R-2,42.5-44$ & 458.84 & 5.16 & 0.37 & 0.06 & 6.12 & 0.16 \\
\hline $9 R-1,53.5-55$ & 467.04 & 0.30 & 0.43 & 0.07 & 6.62 & 0.17 \\
\hline 9R-1, 105.5-106 & 467.56 & 3.45 & 0.38 & 0.06 & 6.12 & 0.21 \\
\hline $9 R-2,41.5-43$ & 468.42 & 1.41 & 0.45 & 0.07 & 6.48 & 0.22 \\
\hline 10R-1, 27.5-29 & 476.28 & 0.42 & 0.49 & 0.07 & 7.23 & 0.21 \\
\hline $10 \mathrm{R}-1,124.5-126$ & 477.25 & 0.45 & 0.32 & 0.06 & 5.16 & 0.14 \\
\hline $11 \mathrm{R}-1,60-61.5$ & 486.11 & 1.02 & 0.37 & 0.06 & 5.77 & 0.19 \\
\hline $11 R-2,46-47.5$ & 487.49 & 1.24 & 0.47 & 0.07 & 6.70 & 0.10 \\
\hline 11R-CC, 19.5-21 & 488.01 & 2.82 & 0.40 & 0.06 & 6.35 & 0.27 \\
\hline $12 \mathrm{R}-1,62.5-64$ & 495.63 & 0.37 & 0.46 & 0.07 & 6.17 & 0.36 \\
\hline $12 \mathrm{R}-2,0-1.5$ & 496.44 & 0.31 & 0.47 & 0.08 & 6.10 & 0.34 \\
\hline 13R-1, 119-120.5 & 505.70 & 1.75 & 0.31 & 0.06 & 5.12 & 0.35 \\
\hline $13 R-2,20-21.5$ & 506.11 & 0.87 & 0.33 & 0.07 & 5.01 & 0.77 \\
\hline $13 R-2,86-87.5$ & 506.77 & 1.82 & 0.33 & 0.07 & 5.09 & 0.52 \\
\hline 14R-1, 104-105.5 & 515.05 & 1.84 & 0.30 & 0.06 & 5.32 & 0.56 \\
\hline $14 \mathrm{R}-2,0-1.5$ & 515.51 & 0.60 & 0.30 & 0.06 & 5.13 & 0.20 \\
\hline $14 \mathrm{R}-2,37-38.5$ & 515.88 & 1.22 & 0.32 & 0.06 & 5.08 & 0.36 \\
\hline $14 \mathrm{R}-3,22.5-24$ & 517.25 & 1.45 & 0.28 & 0.06 & 4.98 & 0.51 \\
\hline 14R-CC, 13-17 & 518.37 & 1.26 & 0.42 & 0.07 & 5.95 & 0.45 \\
\hline 15R-1, 0-1.5 & 523.51 & 1.19 & 0.34 & 0.06 & 5.99 & 0.55 \\
\hline $15 R-1,121-122.5$ & 524.72 & 1.98 & 0.37 & 0.07 & 5.58 & 0.40 \\
\hline $15 R-2,57-58.5$ & 525.58 & 0.97 & 0.36 & 0.07 & 5.45 & 0.61 \\
\hline 16R-1, 100-101.5 & 534.01 & 2.17 & 0.37 & 0.08 & 4.86 & 0.31 \\
\hline 17R-1, 15-16.5 & 542.66 & 3.01 & 0.30 & 0.06 & 5.02 & 0.20 \\
\hline 18R-1, 113-114.5 & 553.14 & 2.84 & 0.33 & 0.06 & 5.04 & 0.48 \\
\hline $19 \mathrm{R}-1,122.5-124$ & 562.73 & 2.06 & 0.37 & 0.07 & 5.49 & 0.63 \\
\hline $19 R-2,78.5-80$ & 563.69 & 1.28 & 0.35 & 0.07 & 5.07 & 0.27 \\
\hline 19R-3, 0-1.5 & 564.32 & 2.33 & 0.37 & 0.07 & 5.20 & 0.60 \\
\hline $19 R-3,43.5-45$ & 564.75 & 3.08 & 0.42 & 0.07 & 5.77 & 0.21 \\
\hline 19R-CC, 13.5-15 & 567.85 & 1.37 & 0.34 & 0.06 & 5.50 & 0.59 \\
\hline 20R-1, 0-1.5 & 571.01 & 4.53 & 0.39 & 0.07 & 5.58 & 0.16 \\
\hline $22 \mathrm{R}-1,0-1.5$ & 590.01 & 14.23 & 0.19 & 0.06 & 3.40 & 0.05 \\
\hline 23R-1, 49-50.5 & 594.00 & 4.31 & 0.30 & 0.06 & 5.01 & 0.18 \\
\hline
\end{tabular}

Notes: CSF $=$ core depth below seafloor. TOC $=$ total organic carbon, $\mathrm{TN}=$ total nitrogen, $\mathrm{TS}=$ total sulfur. 
Table T18. Sample depth and processing for microbiological and biogeochemical studies, Site C0006. (See table notes.) (Continued on next page.)

\begin{tabular}{|c|c|c|c|c|c|c|}
\hline \multirow{2}{*}{$\begin{array}{l}\text { Core, } \\
\text { section }\end{array}$} & \multirow{2}{*}{$\begin{array}{l}\text { Depth } \\
\text { CSF (m) }\end{array}$} & \multicolumn{2}{|c|}{ Frozen } & \multirow{2}{*}{$\begin{array}{l}\text { Anaerobic } \\
\text { pack }\left(4^{\circ} \mathrm{C}\right)\end{array}$} & \multicolumn{2}{|c|}{ Slurry $\left(-20^{\circ} \mathrm{C}\right)$} \\
\hline & & $-80^{\circ} \mathrm{C}$ & $-20^{\circ} \mathrm{C}$ & & FISH & Acetone \\
\hline \multicolumn{7}{|c|}{ 316-C0006C- } \\
\hline $1 \mathrm{H}-1$ & 0.57 & $x$ & & & $x$ & $x$ \\
\hline $1 \mathrm{H}-1$ & 0.71 & & & $x$ & & \\
\hline $1 \mathrm{H}-1$ & 0.75 & $x$ & & $x$ & $x$ & \\
\hline $1 \mathrm{H}-1$ & 0.92 & $x$ & & & & \\
\hline $1 \mathrm{H}-1$ & 0.99 & & & $x$ & & \\
\hline $1 \mathrm{H}-1$ & 1.13 & & $x$ & & & \\
\hline $1 \mathrm{H}-5$ & 4.56 & $x$ & & & $x$ & $x$ \\
\hline $1 \mathrm{H}-5$ & 4.69 & & & $x$ & & \\
\hline $1 \mathrm{H}-5$ & 4.83 & $x$ & & $x$ & $x$ & \\
\hline $1 \mathrm{H}-5$ & 4.90 & $x$ & & & & \\
\hline $1 \mathrm{H}-5$ & 4.97 & & & $x$ & & \\
\hline $1 \mathrm{H}-5$ & 5.02 & & $x$ & & & \\
\hline \multicolumn{7}{|c|}{ 316-C0006D- } \\
\hline $1 \mathrm{H}-1$ & 0.80 & $x$ & & & $x$ & $x$ \\
\hline $1 \mathrm{H}-1$ & 0.94 & & & $x$ & & \\
\hline $1 \mathrm{H}-1$ & 1.08 & $x$ & & $x$ & $x$ & \\
\hline $1 \mathrm{H}-1$ & 1.15 & $x$ & & & & \\
\hline $1 \mathrm{H}-1$ & 1.19 & & $x$ & & & \\
\hline $1 \mathrm{H}-4$ & 3.64 & $x$ & & & $\mathrm{x}$ & $x$ \\
\hline $1 \mathrm{H}-4$ & 3.77 & & & $x$ & & \\
\hline $1 \mathrm{H}-4$ & 3.84 & $x$ & & $x$ & $x$ & \\
\hline $1 \mathrm{H}-4$ & 3.98 & $\mathrm{x}$ & & & & \\
\hline $1 \mathrm{H}-4$ & 4.03 & & $x$ & & & \\
\hline $1 \mathrm{H}-9$ & 8.56 & & $x$ & & & \\
\hline $1 \mathrm{H}-9$ & 8.64 & $x$ & & & $x$ & $x$ \\
\hline $1 \mathrm{H}-9$ & 8.80 & & & $x$ & & \\
\hline \multicolumn{7}{|c|}{ 316-C0006E- } \\
\hline $1 \mathrm{H}-1$ & 0.00 & & & $x$ & $x$ & $x$ \\
\hline $1 \mathrm{H}-3$ & 2.18 & & & $x$ & & \\
\hline $1 \mathrm{H}-3$ & 2.28 & $x$ & & & & \\
\hline $1 \mathrm{H}-3$ & 2.48 & $x$ & & $x$ & $x$ & \\
\hline $1 \mathrm{H}-3$ & 2.58 & & & $x$ & & \\
\hline $1 \mathrm{H}-3$ & 2.73 & $x$ & & & $x$ & $x$ \\
\hline $2 \mathrm{H}-6$ & 10.98 & $x$ & & & $x$ & $x$ \\
\hline $2 \mathrm{H}-6$ & 11.13 & & & $x$ & & \\
\hline $2 \mathrm{H}-6$ & 11.33 & $x$ & & $x$ & $x$ & \\
\hline $2 \mathrm{H}-6$ & 11.43 & $x$ & & & & \\
\hline $2 \mathrm{H}-6$ & 11.47 & & $x$ & & & \\
\hline $3 \mathrm{H}-5$ & 19.07 & $x$ & & & $x$ & $x$ \\
\hline $3 \mathrm{H}-5$ & 19.22 & & & $x$ & & \\
\hline $3 \mathrm{H}-5$ & 19.37 & $x$ & & $x$ & $x$ & \\
\hline $3 \mathrm{H}-5$ & 19.44 & $\mathrm{x}$ & & & & \\
\hline $3 \mathrm{H}-5$ & 19.66 & & $x$ & & & \\
\hline $3 \mathrm{H}-5$ & 19.93 & & & $x$ & & \\
\hline $5 \mathrm{H}-2$ & 35.37 & $x$ & & & & \\
\hline $5 \mathrm{H}-2$ & 35.51 & $x$ & & $x$ & $x$ & \\
\hline $5 \mathrm{H}-2$ & 35.59 & & & $\mathrm{x}$ & & \\
\hline $5 \mathrm{H}-2$ & 35.74 & $x$ & & & $x$ & $x$ \\
\hline $7 \mathrm{H}-7$ & 46.38 & $x$ & & & $x$ & $x$ \\
\hline $7 \mathrm{H}-7$ & 46.53 & & & $x$ & & \\
\hline $7 \mathrm{H}-7$ & 46.69 & $\mathrm{x}$ & & $x$ & $x$ & \\
\hline $7 \mathrm{H}-7$ & 46.77 & $\mathrm{x}$ & & & & \\
\hline $7 \mathrm{H}-7$ & 46.81 & & $x$ & & & \\
\hline $9 \mathrm{H}-6$ & 63.39 & $x$ & & & & \\
\hline $9 \mathrm{H}-6$ & 63.59 & $x$ & & $x$ & $x$ & \\
\hline $9 \mathrm{H}-6$ & 63.69 & & & $x$ & & \\
\hline $9 \mathrm{H}-6$ & 63.84 & $x$ & & & $x$ & $x$ \\
\hline $9 \mathrm{H}-6$ & 63.96 & & $x$ & & & \\
\hline $12 \mathrm{H}-5$ & 76.06 & & & $x$ & & \\
\hline $12 \mathrm{H}-5$ & 76.21 & $x$ & & & $x$ & $x$ \\
\hline $17 X-2$ & 99.84 & $x$ & & & $x$ & $x$ \\
\hline $17 X-2$ & 99.99 & & & $x$ & & \\
\hline $17 X-2$ & 100.16 & $x$ & & $x$ & $x$ & \\
\hline $17 X-2$ & 100.24 & $x$ & & & & \\
\hline $17 X-2$ & 100.28 & & $x$ & & & \\
\hline
\end{tabular}

\begin{tabular}{|c|c|c|c|c|c|c|}
\hline \multirow{2}{*}{$\begin{array}{l}\text { Core, } \\
\text { section }\end{array}$} & \multirow{2}{*}{$\begin{array}{c}\text { Depth } \\
\text { CSF (m) }\end{array}$} & \multicolumn{2}{|c|}{ Frozen } & \multirow{2}{*}{$\begin{array}{l}\text { Anaerobic } \\
\text { pack }\left(4^{\circ} \mathrm{C}\right)\end{array}$} & \multicolumn{2}{|c|}{ Slurry $\left(-20^{\circ} \mathrm{C}\right)$} \\
\hline & & $-80^{\circ} \mathrm{C}$ & $-20^{\circ} \mathrm{C}$ & & FISH & Acetone \\
\hline $25 X-4$ & 177.15 & $\mathrm{x}$ & & & $\mathrm{x}$ & $\mathrm{x}$ \\
\hline $25 X-4$ & 177.30 & $\mathrm{x}$ & & & $\mathrm{x}$ & $\mathrm{x}$ \\
\hline $25 X-4$ & 177.46 & & & $x$ & & \\
\hline $25 X-4$ & 177.53 & $x$ & & $x$ & $x$ & \\
\hline $25 X-4$ & 177.57 & $\mathrm{x}$ & & & & \\
\hline $25 X-7$ & 181.11 & $\mathrm{x}$ & & & $\mathrm{x}$ & \\
\hline $27 X-4$ & 193.55 & $\mathrm{x}$ & & & $\mathrm{x}$ & $\mathrm{x}$ \\
\hline $27 X-4$ & 193.70 & & & $\mathrm{x}$ & & \\
\hline $27 X-4$ & 193.42 & $\mathrm{x}$ & & $x$ & $\mathrm{x}$ & \\
\hline $27 X-4$ & 193.28 & $\mathrm{x}$ & & & & \\
\hline $27 X-4$ & 197.48 & $\mathrm{x}$ & & & $\mathrm{x}$ & \\
\hline $27 X-5$ & 197.68 & $\mathrm{x}$ & & & & \\
\hline $27 X-5$ & 197.78 & $\mathrm{x}$ & $\mathrm{x}$ & & $\mathrm{x}$ & $\mathrm{x}$ \\
\hline $28 X-2$ & 203.80 & $x$ & & & $x$ & \\
\hline $29 X-6$ & 219.03 & $x$ & & & $\mathrm{x}$ & \\
\hline $30 X-5$ & 225.98 & $x$ & & & $\mathrm{x}$ & \\
\hline $31 X-2$ & 232.31 & $x$ & & & $x$ & \\
\hline $32 X-6$ & 246.41 & $\mathrm{x}$ & & & $\mathrm{x}$ & \\
\hline $34 X-7$ & 265.88 & $\mathrm{x}$ & & & $\mathrm{x}$ & $\mathrm{x}$ \\
\hline $34 X-7$ & 266.03 & & & $\mathrm{x}$ & & \\
\hline $34 X-7$ & 266.19 & $x$ & & $x$ & $\mathrm{x}$ & \\
\hline $34 X-7$ & 266.26 & $\mathrm{x}$ & & & & \\
\hline $34 X-7$ & 266.30 & & $x$ & & & \\
\hline $35 X-3$ & 270.45 & $x$ & & & $\mathrm{x}$ & \\
\hline $36 X-3$ & 281.55 & $x$ & & & $\mathrm{x}$ & \\
\hline $37 X-4$ & 292.11 & $x$ & & & $\mathrm{x}$ & \\
\hline $39 X-6$ & 311.58 & $x$ & & & $x$ & $x$ \\
\hline $39 X-6$ & 311.73 & & & $\mathrm{x}$ & & \\
\hline $39 X-6$ & 311.88 & $x$ & & $x$ & $\mathrm{x}$ & \\
\hline $39 X-6$ & 311.95 & $x$ & & & & \\
\hline $39 X-6$ & 312.00 & & $x$ & & & \\
\hline $40 X-4$ & 320.58 & $x$ & & & $\mathrm{x}$ & \\
\hline $41 X-5$ & 330.46 & $x$ & & & $x$ & \\
\hline $42 X-4$ & 339.57 & $x$ & & & $\mathrm{x}$ & \\
\hline $43 X-4$ & 349.10 & $\mathrm{x}$ & & & $\mathrm{x}$ & \\
\hline $44 X-7$ & 360.52 & $x$ & & & $x$ & $x$ \\
\hline $44 X-7$ & 360.67 & & & $x$ & & \\
\hline $44 X-7$ & 360.82 & $x$ & & $\mathrm{x}$ & $\mathrm{x}$ & \\
\hline $44 X-7$ & 360.89 & $x$ & & & & \\
\hline $44 X-7$ & 360.94 & & $x$ & & & \\
\hline $45 X-3$ & 366.65 & $x$ & & & $x$ & \\
\hline $46 X-4$ & 377.59 & $x$ & & & $x$ & \\
\hline $47 X-5$ & 387.09 & $x$ & & & $x$ & \\
\hline $48 X-4$ & 396.97 & $x$ & & & $x$ & \\
\hline $49 X-2$ & 403.55 & $x$ & & & $x$ & $x$ \\
\hline $49 X-2$ & 403.40 & & & $x$ & & \\
\hline $49 X-3$ & 404.67 & $x$ & & & $x$ & \\
\hline \multicolumn{7}{|c|}{ 316-C0006F- } \\
\hline $2 \mathrm{R}-1$ & 405.51 & & & & $x$ & \\
\hline $2 \mathrm{R}-2$ & 405.58 & $x$ & & & $x$ & $x$ \\
\hline $3 R-2$ & 414.45 & $x$ & & & $x$ & $x$ \\
\hline $3 R-2$ & 414.71 & & & $x$ & & \\
\hline $4 \mathrm{R}-1$ & 423.51 & & & & $x$ & \\
\hline $5 \mathrm{R}-1$ & 434.32 & & & & $x$ & \\
\hline $6 \mathrm{R}-2$ & 439.69 & & & & $x$ & \\
\hline 7R-1 & 447.84 & $x$ & & & & \\
\hline 7R-1 & 447.89 & & & $x$ & & \\
\hline 7R-1 & 447.95 & $x$ & & & $x$ & $x$ \\
\hline 7R-1 & 447.95 & & $x$ & $x$ & $x$ & \\
\hline 7R-1 & 448.53 & & $x$ & & & \\
\hline $8 \mathrm{R}-1$ & 458.22 & $x$ & & & $x$ & $x$ \\
\hline 9R-1 & 467.24 & $x$ & $x$ & & $x$ & $x$ \\
\hline $10 \mathrm{R}-2$ & 478.88 & $x$ & & & $x$ & \\
\hline 11R-1 & 487.56 & & & & $x$ & \\
\hline $12 \mathrm{R}-1$ & 495.73 & & & $x$ & & \\
\hline 12R-1 & 495.80 & & $x$ & $x$ & $x$ & \\
\hline $12 \mathrm{R}-1$ & 495.80 & $x$ & & & $x$ & $x$ \\
\hline
\end{tabular}


Table T18 (continued).

\begin{tabular}{|c|c|c|c|c|c|c|}
\hline \multirow{2}{*}{$\begin{array}{l}\text { Core, } \\
\text { section }\end{array}$} & \multirow{2}{*}{$\begin{array}{l}\text { Depth } \\
\text { CSF (m) }\end{array}$} & \multicolumn{2}{|c|}{ Frozen } & \multirow{2}{*}{$\begin{array}{l}\text { Anaerobic } \\
\text { pack }\left(4^{\circ} \mathrm{C}\right)\end{array}$} & \multicolumn{2}{|c|}{ Slurry $\left(-20^{\circ} \mathrm{C}\right)$} \\
\hline & & $-80^{\circ} \mathrm{C}$ & $-20^{\circ} \mathrm{C}$ & & FISH & Acetone \\
\hline $12 \mathrm{R}-1$ & 495.87 & $x$ & & & & \\
\hline $12 \mathrm{R}-2$ & 496.64 & & $x$ & & & \\
\hline $13 R-2$ & 506.11 & & & & $x$ & \\
\hline $14 \mathrm{R}-2$ & 516.80 & & & & $x$ & \\
\hline $15 R-1$ & 523.71 & $x$ & $x$ & & $x$ & \\
\hline $16 \mathrm{R}-1$ & 534.21 & $x$ & & & $x$ & $x$ \\
\hline 17R-1 & 542.78 & $x$ & & & $x$ & $x$ \\
\hline $17 R-2$ & 544.30 & & & $x$ & $x$ & $x$ \\
\hline $18 \mathrm{R}-1$ & 553.30 & & & & $x$ & \\
\hline $19 R-3$ & 565.47 & & & & $x$ & \\
\hline $20 \mathrm{R}-1$ & 571.34 & & & & $x$ & \\
\hline $22 \mathrm{R}-1$ & 590.45 & $x$ & & & $x$ & $x$ \\
\hline $22 \mathrm{R}-1$ & 590.50 & & $x$ & $x$ & $x$ & \\
\hline $22 \mathrm{R}-1$ & 590.54 & & & $x$ & & \\
\hline $22 \mathrm{R}-1$ & 590.59 & $x$ & & & & \\
\hline
\end{tabular}

Notes: Sample depths of Holes C0006C and C00006D indicate the length from the top of Core 1, not from the seafloor. CSF = core depth below seafloor. FISH = fluorescence in situ hybridization. 
Table T19. Thermal conductivity measurements, Site C0006. (See table notes.) (Continued on next two pages.)

\begin{tabular}{|c|c|c|c|c|c|c|c|}
\hline \multirow{2}{*}{$\begin{array}{l}\text { Core, section, } \\
\text { interval }(\mathrm{cm})\end{array}$} & \multirow{2}{*}{$\begin{array}{l}\text { Depth } \\
\text { CSF }(m)\end{array}$} & \multirow[b]{2}{*}{ Method* } & \multicolumn{2}{|c|}{$\begin{array}{l}\text { Thermal conductivity } \\
(\mathrm{W} /[\mathrm{m} \cdot \mathrm{K}])\end{array}$} & \multirow[b]{2}{*}{$N$} & \multirow{2}{*}{$\begin{array}{l}\text { Standard } \\
\text { deviation } \\
(\mathrm{W} /[\mathrm{m} \cdot \mathrm{K}])\end{array}$} & \multirow{2}{*}{$\begin{array}{l}\text { Thermal } \\
\text { conductivity } \\
(\mathrm{W} /[\mathrm{m} \cdot \mathrm{K}])^{\ddagger}\end{array}$} \\
\hline & & & Raw average & Calibrated $^{\dagger}$ & & & \\
\hline \multicolumn{8}{|l|}{ 316-C0006C- } \\
\hline $01 \mathrm{H}-1,20$ & 0.20 & V10305 & 0.99 & 0.94 & 3 & 0.00 & 0.96 \\
\hline $01 \mathrm{H}-3,45$ & 1.93 & V10305 & 1.07 & 1.02 & 3 & 0.02 & 1.05 \\
\hline $01 \mathrm{H}-5,40$ & 4.86 & V10305 & 1.15 & 1.11 & 3 & 0.06 & 1.13 \\
\hline $01 \mathrm{H}-7,40$ & 6.59 & V10305 & 1.22 & 1.18 & 2 & 0.01 & 1.21 \\
\hline $01 \mathrm{H}-9,43$ & 9.40 & V10305 & 1.05 & 1.00 & 2 & 0.06 & 1.03 \\
\hline \multicolumn{8}{|l|}{ 316-C0006D- } \\
\hline $01 \mathrm{H}-1,40$ & 0.40 & V10305 & 1.10 & 1.05 & 3 & 0.00 & 1.08 \\
\hline $01 \mathrm{H}-3,60$ & 2.03 & V10305 & 1.35 & 1.31 & 3 & 0.01 & 1.35 \\
\hline $01 \mathrm{H}-6,70$ & 4.96 & V10305 & 1.28 & 1.24 & 3 & 0.04 & 1.27 \\
\hline $01 \mathrm{H}-8,65$ & 7.78 & V10305 & 1.23 & 1.19 & 3 & 0.01 & 1.21 \\
\hline $01 \mathrm{H}-10,60$ & 9.97 & V10305 & 1.20 & 1.16 & 3 & 0.02 & 1.19 \\
\hline \multicolumn{8}{|l|}{ 316-C0006E- } \\
\hline $01 \mathrm{H}-1,50$ & 0.50 & V10305 & 1.04 & 1.00 & 3 & 0.00 & 1.02 \\
\hline $01 \mathrm{H}-3,60$ & 2.03 & V10305 & 1.30 & 1.26 & 3 & 0.01 & 1.29 \\
\hline $01 \mathrm{H}-6,48$ & 4.95 & V10305 & 1.23 & 1.19 & 3 & 0.00 & 1.22 \\
\hline $02 \mathrm{H}-2,100$ & 7.60 & V10305 & 1.35 & 1.31 & 3 & 0.00 & 1.34 \\
\hline $02 \mathrm{H}-4,80$ & 8.82 & V10305 & 1.15 & 1.11 & 3 & 0.01 & 1.14 \\
\hline $02 \mathrm{H}-6,35$ & 11.23 & V10305 & 0.99 & 0.94 & 2 & 0.00 & 0.96 \\
\hline $02 \mathrm{H}-8,60$ & 12.93 & V10305 & 1.27 & 1.23 & 3 & 0.03 & 1.26 \\
\hline $03 \mathrm{H}-2,50$ & 16.60 & V10305 & 1.24 & 1.20 & 3 & 0.01 & 1.23 \\
\hline $03 \mathrm{H}-4,55$ & 18.07 & V10305 & 1.33 & 1.29 & 3 & 0.04 & 1.32 \\
\hline $03 \mathrm{H}-6,83$ & 21.26 & V10305 & 1.14 & 1.10 & 3 & 0.01 & 1.12 \\
\hline $03 \mathrm{H}-8,65$ & 22.54 & V10305 & 1.35 & 1.31 & 3 & 0.01 & 1.34 \\
\hline $04 \mathrm{H}-1,71$ & 24.90 & V10305 & 1.02 & 0.98 & 3 & 0.03 & 1.00 \\
\hline $04 \mathrm{H}-3,65$ & 27.69 & V10305 & 1.12 & 1.08 & 3 & 0.01 & 1.11 \\
\hline $04 \mathrm{H}-6,60$ & 30.76 & V10305 & 0.74 & 0.69 & 3 & 0.01 & 0.70 \\
\hline $04 \mathrm{H}-6,100$ & 31.16 & V10305 & 1.12 & 1.08 & 3 & 0.02 & 1.10 \\
\hline $05 \mathrm{H}-1,100$ & 34.22 & V10305 & 1.03 & 0.99 & 3 & 0.01 & 1.01 \\
\hline $05 \mathrm{H}-1,125$ & 34.47 & V10305 & 1.22 & 1.18 & 3 & 0.04 & 1.21 \\
\hline $05 \mathrm{H}-4,70$ & 36.76 & V10305 & 1.09 & 1.05 & 3 & 0.01 & 1.07 \\
\hline $07 \mathrm{H}-1,20$ & 38.89 & V10305 & 0.83 & 0.79 & 3 & 0.00 & 0.81 \\
\hline $07 \mathrm{H}-5,90$ & 44.06 & V10305 & 1.10 & 1.06 & 4 & 0.01 & 1.08 \\
\hline $07 \mathrm{H}-7,20$ & 46.18 & V10305 & 0.92 & 0.87 & 3 & 0.01 & 0.89 \\
\hline $08 \mathrm{H}-1,50$ & 48.69 & V10305 & 1.03 & 0.99 & 3 & 0.04 & 1.01 \\
\hline $08 \mathrm{H}-1,90$ & 49.09 & V10305 & 0.96 & 0.91 & 5 & 0.03 & 0.93 \\
\hline $08 \mathrm{H}-3,60$ & 51.61 & V10305 & 1.21 & 1.17 & 3 & 0.02 & 1.20 \\
\hline $08 \mathrm{H}-5,50$ & 52.53 & V10305 & 1.16 & 1.11 & 3 & 0.01 & 1.14 \\
\hline $08 \mathrm{H}-8,30$ & 56.58 & V10305 & 1.01 & 0.96 & 3 & 0.00 & 0.99 \\
\hline $08 \mathrm{H}-9,30$ & 57.99 & V10305 & 0.91 & 0.87 & 3 & 0.05 & 0.89 \\
\hline $09 \mathrm{H}-1,30$ & 57.99 & V10305 & 0.78 & 0.73 & 3 & 0.01 & 0.75 \\
\hline $09 \mathrm{H}-2,80$ & 59.91 & V10305 & 0.96 & 0.92 & 3 & 0.03 & 0.94 \\
\hline $11 \mathrm{H}-5,70$ & 68.61 & V10305 & 1.31 & 1.27 & 3 & 0.04 & 1.30 \\
\hline $13 \mathrm{H}-1,60$ & 78.42 & V10305 & 1.14 & 1.10 & 3 & 0.01 & 1.13 \\
\hline $15 X-1,68$ & 80.01 & V10305 & 1.22 & 1.17 & 4 & 0.04 & 1.20 \\
\hline $15 X-3,15$ & 81.20 & V10305 & 1.05 & 1.01 & 2 & 0.00 & 1.03 \\
\hline $15 X-5,43$ & 82.40 & V10305 & 1.21 & 1.17 & 3 & 0.00 & 1.20 \\
\hline $15 X-7,19$ & 84.62 & V10305 & 1.21 & 1.17 & 3 & 0.00 & 1.19 \\
\hline $16 X-1,25$ & 89.08 & V10305 & 0.96 & 0.91 & 3 & 0.01 & 0.93 \\
\hline $16 X-3,20$ & 90.54 & V10305 & 1.10 & 1.06 & 4 & 0.02 & 1.08 \\
\hline $17 X-1,30$ & 98.63 & V10305 & 0.91 & 0.86 & 3 & 0.00 & 0.88 \\
\hline $17 X-4,50$ & 101.05 & V10305 & 1.23 & 1.19 & 4 & 0.01 & 1.22 \\
\hline $17 X-5,20$ & 101.38 & V10305 & 1.15 & 1.10 & 3 & 0.01 & 1.13 \\
\hline $18 \mathrm{X}-1,80$ & 107.13 & V10305 & 1.19 & 1.15 & 3 & 0.00 & 1.18 \\
\hline $19 X-1,65$ & 116.48 & V10305 & 1.20 & 1.16 & 3 & 0.00 & 1.19 \\
\hline $19 X-3,80$ & 118.06 & V10305 & 1.17 & 1.13 & 3 & 0.03 & 1.16 \\
\hline $19 X-3,120$ & 118.46 & V10305 & 1.12 & 1.08 & 3 & 0.00 & 1.10 \\
\hline $19 X-4,90$ & 119.57 & V10305 & 1.06 & 1.02 & 3 & 0.00 & 1.04 \\
\hline $19 X-6,25$ & 120.33 & V10305 & 1.13 & 1.09 & 3 & 0.00 & 1.11 \\
\hline $20 X-1,110$ & 126.43 & V10305 & 1.29 & 1.25 & 3 & 0.01 & 1.28 \\
\hline $20 X-3,100$ & 129.16 & V10305 & 1.09 & 1.05 & 2 & 0.00 & 1.07 \\
\hline $20 X-5,75$ & 131.76 & V10305 & 1.23 & 1.19 & 3 & 0.02 & 1.22 \\
\hline $21 X-1,80$ & 135.63 & V10305 & 1.25 & 1.21 & 3 & 0.01 & 1.24 \\
\hline $21 X-2,80$ & 137.08 & V10305 & 1.33 & 1.29 & 3 & 0.01 & 1.32 \\
\hline $21 X-4,80$ & 138.50 & V10305 & 1.12 & 1.08 & 3 & 0.00 & 1.10 \\
\hline $22 X-1,105$ & 145.38 & V10305 & 1.27 & 1.23 & 3 & 0.01 & 1.25 \\
\hline $22 X-2,80$ & 146.54 & V10305 & 1.24 & 1.20 & 3 & 0.00 & 1.22 \\
\hline
\end{tabular}


Table T19 (continued). (Continued on next page.)

\begin{tabular}{|c|c|c|c|c|c|c|c|}
\hline \multirow{2}{*}{$\begin{array}{l}\text { Core, section, } \\
\text { interval }(\mathrm{cm})\end{array}$} & \multirow{2}{*}{$\begin{array}{l}\text { Depth } \\
\text { CSF (m) }\end{array}$} & \multirow[b]{2}{*}{ Method* } & \multicolumn{2}{|c|}{$\begin{array}{l}\text { Thermal conductivity } \\
(\mathrm{W} /[\mathrm{m} \cdot \mathrm{K}])\end{array}$} & \multirow[b]{2}{*}{$N$} & \multirow{2}{*}{$\begin{array}{l}\text { Standard } \\
\text { deviation } \\
(\mathrm{W} /[\mathrm{m} \cdot \mathrm{K}])\end{array}$} & \multirow{2}{*}{$\begin{array}{c}\text { Thermal } \\
\text { conductivity } \\
(\mathrm{W} /[\mathrm{m} \cdot \mathrm{K}])^{\ddagger}\end{array}$} \\
\hline & & & Raw average & Calibrated $^{\dagger}$ & & & \\
\hline $22 X-4,80$ & 147.98 & V10305 & 1.24 & 1.20 & 3 & 0.02 & 1.22 \\
\hline $22 X-4,120$ & 148.38 & V10305 & 1.40 & 1.36 & 3 & 0.01 & 1.39 \\
\hline $22 X-6,60$ & 150.60 & V10305 & 1.34 & 1.31 & 3 & 0.00 & 1.33 \\
\hline $23 X-1,85$ & 154.68 & V10305 & 1.18 & 1.14 & 3 & 0.02 & 1.17 \\
\hline $23 X-3,50$ & 157.15 & V10305 & 1.13 & 1.09 & 3 & 0.01 & 1.11 \\
\hline $23 X-5,80$ & 158.88 & V10305 & 1.14 & 1.10 & 3 & 0.02 & 1.12 \\
\hline $23 X-7,65$ & 161.55 & V10305 & 1.22 & 1.18 & 3 & 0.01 & 1.20 \\
\hline $24 X-1,50$ & 163.83 & V10305 & 1.18 & 1.14 & 3 & 0.03 & 1.16 \\
\hline $25 X-1,90$ & 173.73 & V10305 & 1.09 & 1.05 & 3 & 0.03 & 1.07 \\
\hline $25 X-3,75$ & 176.39 & V10305 & 1.14 & 1.10 & 3 & 0.02 & 1.12 \\
\hline $25 X-5,50$ & 178.96 & V10305 & 1.38 & 1.34 & 3 & 0.05 & 1.37 \\
\hline $25 X-5,100$ & 179.46 & V10305 & 1.40 & 1.36 & 2 & 0.04 & 1.39 \\
\hline $25 X-6,50$ & 180.37 & V10305 & 1.27 & 1.23 & 3 & 0.03 & 1.26 \\
\hline $25 X-8,25$ & 181.38 & V10305 & 1.36 & 1.32 & 3 & 0.01 & 1.35 \\
\hline $26 X-1,120$ & 183.53 & V10305 & 1.23 & 1.18 & 3 & 0.00 & 1.21 \\
\hline $26 X-3,70$ & 185.94 & V10305 & 1.36 & 1.32 & 3 & 0.01 & 1.35 \\
\hline $26 X-5,45$ & 187.41 & V10305 & 1.18 & 1.14 & 3 & 0.00 & 1.17 \\
\hline $26 X-7,40$ & 189.86 & V10305 & 1.46 & 1.42 & 2 & 0.01 & 1.45 \\
\hline $26 X-8,50$ & 191.38 & V10305 & 1.24 & 1.20 & 3 & 0.03 & 1.22 \\
\hline $27 X-1,80$ & 192.63 & V10305 & 1.18 & 1.14 & 3 & 0.01 & 1.17 \\
\hline $27 X-2,60$ & 193.84 & V10305 & 1.33 & 1.29 & 3 & 0.01 & 1.32 \\
\hline $27 X-3,60$ & 195.26 & V10305 & 1.29 & 1.25 & 3 & 0.00 & 1.27 \\
\hline $27 X-4,40$ & 196.48 & V10305 & 1.47 & 1.43 & 3 & 0.01 & 1.46 \\
\hline $27 X-6,80$ & 198.67 & V10305 & 1.33 & 1.29 & 3 & 0.02 & 1.31 \\
\hline $27 X-8,90$ & 201.22 & V10305 & 1.46 & 1.43 & 3 & 0.01 & 1.46 \\
\hline $28 X-1,90$ & 202.23 & V10305 & 1.33 & 1.29 & 3 & 0.01 & 1.32 \\
\hline $28 X-2,70$ & 203.44 & V10305 & 1.37 & 1.33 & 3 & 0.01 & 1.36 \\
\hline $28 X-4,50$ & 204.67 & V10305 & 1.23 & 1.19 & 3 & 0.01 & 1.21 \\
\hline $29 X-1,50$ & 211.33 & V10305 & 1.08 & 1.04 & 3 & 0.12 & 1.06 \\
\hline $29 X-2,50$ & 212.76 & V10305 & 1.26 & 1.22 & 3 & 0.04 & 1.25 \\
\hline $29 X-3,80$ & 214.47 & V10305 & 0.76 & 0.72 & 3 & 0.09 & 0.73 \\
\hline $29 X-4,80$ & 215.88 & V10305 & 0.92 & 0.87 & 3 & 0.03 & 0.89 \\
\hline $29 X-5,80$ & 217.29 & V10305 & 1.27 & 1.23 & 3 & 0.02 & 1.26 \\
\hline $29 X-6,90$ & 218.85 & V10305 & 1.09 & 1.05 & 3 & 0.01 & 1.07 \\
\hline $29 X-8,75$ & 220.13 & V10305 & 1.36 & 1.32 & 3 & 0.01 & 1.35 \\
\hline $30 X-1,50$ & 220.83 & V10305 & 0.82 & 0.77 & 2 & 0.00 & 0.79 \\
\hline $30 X-1,115$ & 221.48 & V10305 & 1.29 & 1.25 & 3 & 0.01 & 1.27 \\
\hline $30 X-2,30$ & 222.04 & V10305 & 1.11 & 1.07 & 3 & 0.01 & 1.10 \\
\hline $30 X-4,50$ & 224.04 & V10305 & 1.41 & 1.37 & 3 & 0.00 & 1.40 \\
\hline $30 x-6,95$ & 226.94 & V10305 & 1.26 & 1.22 & 3 & 0.01 & 1.24 \\
\hline $30 X-8,70$ & 229.52 & V10305 & 1.39 & 1.36 & 3 & 0.00 & 1.38 \\
\hline $31 X-1,65$ & 230.48 & V10305 & 1.37 & 1.33 & 3 & 0.01 & 1.36 \\
\hline $31 X-2,95$ & 232.22 & V10305 & 1.56 & 1.52 & 3 & 0.01 & 1.55 \\
\hline $31 X-4,25$ & 232.94 & V10305 & 1.31 & 1.27 & 3 & 0.01 & 1.30 \\
\hline $31 X-5,72$ & 234.83 & V10305 & 1.18 & 1.14 & 3 & 0.05 & 1.16 \\
\hline $32 X-1,80$ & 240.13 & V10305 & 1.14 & 1.10 & 3 & 0.00 & 1.13 \\
\hline $32 X-2,80$ & 241.56 & V10305 & 1.08 & 1.04 & 3 & 0.01 & 1.06 \\
\hline $32 X-3,50$ & 242.67 & V10305 & 1.45 & 1.41 & 3 & 0.01 & 1.44 \\
\hline $32 X-5,70$ & 244.29 & V10305 & 1.00 & 0.96 & 3 & 0.00 & 0.98 \\
\hline $32 X-6,63$ & 245.64 & V10305 & 1.20 & 1.16 & 3 & 0.04 & 1.19 \\
\hline $32 X-8,30$ & 247.63 & V10305 & 1.21 & 1.17 & 3 & 0.01 & 1.20 \\
\hline $34 X-1,103$ & 259.36 & V10305 & 1.13 & 1.09 & 3 & 0.05 & 1.11 \\
\hline $34 X-2,100$ & 260.74 & V10305 & 1.15 & 1.11 & 3 & 0.01 & 1.13 \\
\hline $34 X-3,105$ & 262.20 & V10305 & 1.27 & 1.23 & 3 & 0.00 & 1.25 \\
\hline $34 X-4,75$ & 263.32 & V10305 & 1.21 & 1.17 & 3 & 0.02 & 1.20 \\
\hline $34 X-6,50$ & 264.50 & V10305 & 1.39 & 1.35 & 3 & 0.05 & 1.38 \\
\hline $34 X-7,20$ & 265.61 & V10305 & 1.09 & 1.05 & 3 & 0.01 & 1.07 \\
\hline $35 X-1,25$ & 268.08 & V10305 & 1.43 & 1.39 & 3 & 0.02 & 1.42 \\
\hline $35 X-3,65$ & 269.71 & V10305 & 1.38 & 1.34 & 2 & 0.01 & 1.37 \\
\hline $35 X-4,50$ & 270.96 & V10305 & 1.33 & 1.29 & 3 & 0.01 & 1.32 \\
\hline $36 X-1,95$ & 278.28 & V10305 & 1.22 & 1.18 & 2 & 0.06 & 1.20 \\
\hline $36 X-2,50$ & 279.24 & V10305 & 1.13 & 1.09 & 3 & 0.01 & 1.11 \\
\hline $36 X-3,111$ & 281.26 & V10305 & 1.29 & 1.25 & 3 & 0.01 & 1.28 \\
\hline $36 X-5,50$ & 282.42 & V10305 & 1.32 & 1.28 & 1 & - & 1.30 \\
\hline $36 X-6,20$ & 283.16 & V10305 & 1.25 & 1.21 & 1 & - & 1.24 \\
\hline $36 X-6,40$ & 283.36 & V10305 & 1.35 & 1.31 & 1 & - & 1.34 \\
\hline $36 X-6,65$ & 283.61 & V10305 & 1.45 & 1.41 & 1 & - & 1.44 \\
\hline $36 X-6,84$ & 283.80 & V10305 & 1.34 & 1.30 & 1 & - & 1.32 \\
\hline
\end{tabular}


Table T19 (continued).

\begin{tabular}{|c|c|c|c|c|c|c|c|}
\hline \multirow{2}{*}{$\begin{array}{l}\text { Core, section, } \\
\text { interval }(\mathrm{cm})\end{array}$} & \multirow{2}{*}{$\begin{array}{l}\text { Depth } \\
\text { CSF (m) }\end{array}$} & \multirow[b]{2}{*}{ Method* } & \multicolumn{2}{|c|}{$\begin{array}{c}\text { Thermal conductivity } \\
(\mathrm{W} /[\mathrm{m} \cdot \mathrm{K}])\end{array}$} & \multirow[b]{2}{*}{$N$} & \multirow{2}{*}{$\begin{array}{l}\text { Standard } \\
\text { deviation } \\
(\mathrm{W} /[\mathrm{m} \cdot \mathrm{K}])\end{array}$} & \multirow{2}{*}{$\begin{array}{c}\text { Thermal } \\
\text { conductivity } \\
(\mathrm{W} /[\mathrm{m} \cdot \mathrm{K}])^{\ddagger}\end{array}$} \\
\hline & & & Raw average & Calibrated $^{\dagger}$ & & & \\
\hline $36 X-6,113$ & 284.09 & V10305 & 1.08 & 1.04 & 1 & - & 1.06 \\
\hline $36 X-7,75$ & 285.13 & V10305 & 1.41 & 1.37 & 1 & - & 1.40 \\
\hline $36 X-8,50$ & 286.28 & V10305 & 1.46 & 1.42 & 1 & - & 1.45 \\
\hline $37 X-1,40$ & 287.23 & V10305 & 1.36 & 1.32 & 1 & - & 1.35 \\
\hline $37 X-1,88$ & 287.71 & V10305 & 1.27 & 1.23 & 1 & - & 1.26 \\
\hline $37 X-2,105$ & 289.30 & V10305 & 1.20 & 1.15 & 1 & - & 1.18 \\
\hline $37 X-3,40$ & 290.06 & V10305 & 1.17 & 1.13 & 1 & - & 1.15 \\
\hline $37 X-3,80$ & 290.46 & V10305 & 1.19 & 1.15 & 1 & - & 1.18 \\
\hline $37 X-3,120$ & 290.86 & V10305 & 1.29 & 1.25 & 1 & - & 1.28 \\
\hline $37 X-4,60$ & 291.67 & V10305 & 1.51 & 1.48 & 3 & 0.16 & 1.51 \\
\hline $37 X-6,50$ & 292.99 & V10305 & 1.27 & 1.23 & 2 & 0.00 & 1.26 \\
\hline $37 X-7,80$ & 294.70 & V10305 & 1.40 & 1.37 & 2 & 0.01 & 1.39 \\
\hline $37 X-8,15$ & 295.46 & V10305 & 0.41 & 0.35 & 1 & - & 0.36 \\
\hline $38 x-3,30$ & 297.21 & V10305 & 1.20 & 1.16 & 2 & 0.05 & 1.19 \\
\hline $39 X-1,26$ & 306.09 & V10305 & 1.03 & 0.98 & 1 & - & 1.00 \\
\hline $39 X-1,60$ & 306.43 & V10305 & 1.21 & 1.16 & 1 & - & 1.19 \\
\hline $39 X-1,110$ & 306.93 & V10305 & 1.20 & 1.16 & 1 & - & 1.18 \\
\hline $39 X-2,62$ & 307.86 & V10305 & 1.19 & 1.14 & 1 & - & 1.17 \\
\hline $39 X-3,15$ & 308.80 & V10305 & 1.01 & 0.96 & 1 & - & 0.98 \\
\hline $39 x-3,60$ & 309.25 & V10305 & 1.19 & 1.15 & 1 & - & 1.17 \\
\hline $39 \times-5,46$ & 310.53 & V10305 & 1.13 & 1.08 & 2 & 0.03 & 1.11 \\
\hline $39 X-5,115$ & 311.22 & V10305 & 1.19 & 1.15 & 2 & 0.04 & 1.17 \\
\hline $39 X-6,30$ & 311.78 & V10305 & 1.05 & 1.01 & 2 & 0.01 & 1.03 \\
\hline $39 X-6,75$ & 312.23 & V10305 & 1.21 & 1.17 & 3 & 0.01 & 1.20 \\
\hline $39 X-7,85$ & 313.74 & V10305 & 1.25 & 1.21 & 2 & 0.01 & 1.24 \\
\hline $40 X-1,100$ & 316.33 & V10305 & 0.32 & 0.26 & 3 & 0.01 & 0.27 \\
\hline $40 \times-2,75$ & 317.49 & H10304 & 1.26 & 1.15 & 3 & 0.03 & 1.18 \\
\hline $40 X-3,30$ & 318.46 & H10304 & 1.18 & 1.06 & 3 & 0.02 & 1.09 \\
\hline $40 X-5,20$ & 320.79 & H10304 & 1.07 & 0.96 & 3 & 0.21 & 0.98 \\
\hline $40 X-8,85$ & 323.26 & H10304 & 1.34 & 1.24 & 3 & 0.07 & 1.26 \\
\hline $43 X-2,125$ & 346.49 & H10304 & 1.44 & 1.35 & 9 & 0.03 & 1.38 \\
\hline $45 X-8,7$ & 371.36 & H10304 & 1.25 & 1.13 & 2 & 0.00 & 1.16 \\
\hline $46 X-4,30$ & 376.87 & H10304 & 1.51 & 1.44 & 15 & 0.01 & 1.47 \\
\hline $47 X-4,39$ & 386.45 & H10304 & 1.54 & 1.48 & 10 & 0.15 & 1.51 \\
\hline $49 X-1,57$ & 401.40 & H10304 & 1.68 & 1.64 & 9 & 0.05 & 1.68 \\
\hline \multicolumn{8}{|l|}{ 316-C0006F- } \\
\hline $06 \mathrm{R}-1,55$ & 438.55 & H10304 & 1.52 & 1.49 & 8 & 0.11 & 1.51 \\
\hline $07 \mathrm{R}-1,62$ & 448.12 & H10304 & 1.31 & 1.27 & 10 & 0.02 & 1.30 \\
\hline $10 \mathrm{R}-1,47$ & 476.47 & H10304 & 1.28 & 1.24 & 5 & 0.00 & 1.26 \\
\hline 11R-1, 21 & 485.15 & H10304 & 1.32 & 1.28 & 6 & 0.01 & 1.31 \\
\hline $12 R-2,60$ & 497.04 & H10304 & 1.46 & 1.42 & 8 & 0.09 & 1.45 \\
\hline 13R-1, 104 & 505.54 & H10304 & 1.24 & 1.20 & 5 & 0.01 & 1.23 \\
\hline $14 \mathrm{R}-3,54$ & 517.56 & H10304 & 1.33 & 1.29 & 5 & 0.00 & 1.32 \\
\hline $18 \mathrm{R}-1,35$ & 552.35 & H10304 & 1.42 & 1.38 & 10 & 0.00 & 1.41 \\
\hline 19R-1, 97 & 562.47 & H10304 & 1.48 & 1.45 & 9 & 0.01 & 1.47 \\
\hline
\end{tabular}

Notes: ${ }^{*}=$ V10305 refers to full-space needle probe and $\mathrm{H} 10304$ refers to half-space line source, $\dagger=$ thermal conductivities were adjusted based on calibration formulas and constants given in the "Expedition 316 methods" chapter, $\ddagger=$ thermal conductivities were corrected for temperature and pressure as described in the "Expedition 316 methods" chapter. CSF = core depth below seafloor. $-=$ not applicable. 
Table T20. Temperature measurements, Hole C0006E. (See table notes.)

\begin{tabular}{|c|c|c|c|c|c|c|c|c|}
\hline \multirow[b]{2}{*}{ Core } & \multirow[b]{2}{*}{ Tool } & \multirow[b]{2}{*}{$\begin{array}{l}\text { Depth } \\
\text { CSF (m) }\end{array}$} & \multirow[b]{2}{*}{$\begin{array}{l}\text { BWT } \\
\left({ }^{\circ} \mathrm{C}\right)\end{array}$} & \multirow[b]{2}{*}{$\begin{array}{c}\text { Time } \\
\text { delay (s) }\end{array}$} & \multicolumn{2}{|c|}{ Fit } & \multirow{2}{*}{$\begin{array}{l}\text { Equilibrium } \\
\text { temperature } \\
\left({ }^{\circ} \mathrm{C}\right)\end{array}$} & \multirow[b]{2}{*}{ Remark } \\
\hline & & & & & $\begin{array}{r}\text { Start } \\
(\mathrm{min})\end{array}$ & $\begin{array}{l}\text { End } \\
\text { (s) }\end{array}$ & & \\
\hline \multicolumn{9}{|c|}{ 316-C0006E- } \\
\hline $3 \mathrm{H}$ & АРCT3 & 24.20 & 1.55 & 15.9 & 1.8 & 9.0 & 2.85 & \\
\hline $5 \mathrm{H}$ & APCT3 & 38.50 & 1.66 & 15.0 & 1.0 & 12.7 & 3.00 & \\
\hline $8 \mathrm{H}$ & АРCT3 & - & - & - & - & - & - & Bad data-tool movement. \\
\hline $10 \mathrm{H}$ & APCT3 & 64.70 & 1.64 & 24.6 & 1.0 & 5.0 & 3.75 & \\
\hline $12 \mathrm{H}$ & АРCT3 & - & - & - & - & - & - & Tool did not deploy. \\
\hline $14 \mathrm{H}$ & АРCT3 & - & - & - & - & - & - & Tool did not penetrate. \\
\hline $16 \mathrm{H}$ & DVTP & 98.30 & 1.69 & 19.7 & 2.0 & 4.8 & 4.82 & Tool movement truncated equilibrium temperature fit. \\
\hline $23 \mathrm{H}$ & DVTP & - & - & - & - & - & - & Power failure-tool. \\
\hline $26 \mathrm{H}$ & DVTP & - & - & - & - & - & - & Thermistor open closed circuit. \\
\hline $28 \mathrm{H}$ & DVTP & - & - & - & - & - & - & Tool stuck in pipe; battery terminal sheared. \\
\hline $29 \mathrm{H}$ & DVTP & 220.30 & 1.69 & 37.9 & 1.5 & 4.8 & 7.87 & Premature pullout. \\
\hline $35 \mathrm{H}$ & DVTP & 277.30 & 1.69 & 105.8 & 2.1 & 7.8 & 3.03 & Tool movement after $7.8 \mathrm{~min}$. \\
\hline $42 \mathrm{H}$ & DVTP & - & - & - & - & - & - & Stiff formation/collet protection activated. \\
\hline
\end{tabular}

Notes: CSF $=$ core depth below seafloor. BWT $=$ bottom water temperature. APCT3 = advanced piston corer temperature tool, DVTP $=$ DavisVillinger temperature probe. $-=$ not measured. 
Table T21. Correlation and depth shifts among all holes, Site C0006. (See table notes.) (Continued on next page.)

\begin{tabular}{|c|c|c|c|c|c|c|c|c|}
\hline \multirow{2}{*}{$\begin{array}{c}\begin{array}{c}\text { Depth } \\
\text { LSF }(\mathrm{m})\end{array} \\
\begin{array}{c}\text { Hole } \\
\text { C0006B }\end{array}\end{array}$} & \multicolumn{4}{|c|}{ Depth CSF-B (m) } & \multicolumn{4}{|c|}{ Depth shift (m) } \\
\hline & $\begin{array}{c}\text { Hole } \\
\text { C0006C }\end{array}$ & $\begin{array}{c}\text { Hole } \\
\text { C0006D }\end{array}$ & $\begin{array}{l}\text { Hole } \\
\text { C0006E }\end{array}$ & $\begin{array}{l}\text { Hole } \\
\text { C0006F }\end{array}$ & $\begin{array}{l}\text { Hole } \\
\text { C0006C }\end{array}$ & $\begin{array}{l}\text { Hole } \\
\text { C0006D }\end{array}$ & $\begin{array}{l}\text { Hole } \\
\text { C0006E }\end{array}$ & $\begin{array}{l}\text { Hole } \\
\text { C0006F }\end{array}$ \\
\hline 3.8 & 2.1 & 0.0 & 2.0 & & -1.7 & -3.8 & -1.8 & \\
\hline 11.5 & 5.8 & 5.4 & 7.5 & & -5.7 & -6.1 & -4.0 & \\
\hline 14.8 & 7.5 & 8.4 & 10.7 & & -7.3 & -6.4 & -4.1 & \\
\hline 24.0 & & & 21.6 & & & & -2.4 & \\
\hline 30.2 & & & 27.2 & & & & -3.0 & \\
\hline 38.7 & & & 36.8 & & & & -1.9 & \\
\hline 49.8 & & & 51.6 & & & & 1.8 & \\
\hline 56.6 & & & 59.4 & & & & 2.8 & \\
\hline 64.2 & & & 66.7 & & & & 2.5 & \\
\hline 71.1 & & & 72.0 & & & & 0.9 & \\
\hline 76.1 & & & 78.1 & & & & 2.0 & \\
\hline 80.8 & & & 80.8 & & & & 0.0 & \\
\hline 86.4 & & & 85.2 & & & & -1.2 & \\
\hline 89.6 & & & 90.1 & & & & 0.5 & \\
\hline 99.3 & & & 99.7 & & & & 0.4 & \\
\hline 109.6 & & & 107.4 & & & & -2.2 & \\
\hline 122.6 & & & 119.7 & & & & -2.9 & \\
\hline 132.5 & & & 128.3 & & & & -4.2 & \\
\hline 141.6 & & & 139.3 & & & & -2.3 & \\
\hline 150.0 & & & 146.8 & & & & -3.2 & \\
\hline 156.7 & & & 155.8 & & & & -0.9 & \\
\hline 163.1 & & & 163.3 & & & & 0.2 & \\
\hline 178.2 & & & 176.8 & & & & -1.4 & \\
\hline 185.5 & & & 183.3 & & & & -2.2 & \\
\hline 199.0 & & & 192.0 & & & & -7.0 & \\
\hline 206.9 & & & 201.2 & & & & -5.7 & \\
\hline 210.5 & & & 204.9 & & & & -5.6 & \\
\hline 224.9 & & & 218.8 & & & & -6.1 & \\
\hline 236.0 & & & 229.8 & & & & -6.2 & \\
\hline 245.2 & & & 239.0 & & & & -6.2 & \\
\hline 248.9 & & & 243.8 & & & & -5.1 & \\
\hline 270.0 & & & 265.0 & & & & -5.0 & \\
\hline 283.5 & & & 278.6 & & & & -4.9 & \\
\hline 289.4 & & & 286.0 & & & & -3.4 & \\
\hline 298.0 & & & 295.2 & & & & -2.8 & \\
\hline 313.6 & & & 311.4 & & & & -2.2 & \\
\hline 326.7 & & & 322.0 & & & & -4.7 & \\
\hline 334.7 & & & 329.9 & & & & -4.8 & \\
\hline 347.8 & & & 343.7 & & & & -4.1 & \\
\hline 358.5 & & & 356.8 & & & & -1.7 & \\
\hline 364.7 & & & 363.8 & & & & -0.9 & \\
\hline 373.7 & & & 372.2 & & & & -1.5 & \\
\hline 381.8 & & & 379.0 & & & & -2.8 & \\
\hline 396.0 & & & 391.3 & & & & -4.7 & \\
\hline 402.3 & & & 396.4 & 395.8 & & & -5.9 & -6.5 \\
\hline 406.8 & & & 400.7 & 400.3 & & & -6.1 & -6.5 \\
\hline 409.7 & & & 404.2 & 403.5 & & & -5.5 & -6.3 \\
\hline 412.4 & & & & 406.6 & & & & -5.8 \\
\hline 420.3 & & & & 415.2 & & & & -5.1 \\
\hline 428.4 & & & & 424.6 & & & & -3.8 \\
\hline 438.2 & & & & 434.6 & & & & -3.6 \\
\hline 443.0 & & & & 438.6 & & & & -4.4 \\
\hline 455.2 & & & & 449.0 & & & & -6.2 \\
\hline 462.7 & & & & 457.5 & & & & -5.2 \\
\hline 473.1 & & & & 467.6 & & & & -5.5 \\
\hline 483.0 & & & & 477.1 & & & & -5.9 \\
\hline 493.0 & & & & 487.1 & & & & -5.9 \\
\hline 501.0 & & & & 496.5 & & & & -4.5 \\
\hline 513.1 & & & & 506.0 & & & & -7.1 \\
\hline 520.2 & & & & 514.4 & & & & -5.8 \\
\hline 524.7 & & & & 518.3 & & & & -6.4 \\
\hline 530.5 & & & & 525.8 & & & & -4.7 \\
\hline 538.3 & & & & 534.9 & & & & -3.4 \\
\hline 558.6 & & & & 553.3 & & & & -5.3 \\
\hline 572.4 & & & & 565.4 & & & & -7.0 \\
\hline
\end{tabular}


Table T21 (continued).

\begin{tabular}{|c|c|c|c|c|c|c|c|c|}
\hline \multirow{2}{*}{$\begin{array}{c}\text { Depth } \\
\text { LSF }(m) \\
\text { Hole } \\
\text { C0006B }\end{array}$} & \multicolumn{4}{|c|}{ Depth CSF-B (m) } & \multicolumn{4}{|c|}{ Depth shift (m) } \\
\hline & $\begin{array}{c}\text { Hole } \\
\text { C0006C }\end{array}$ & $\begin{array}{c}\text { Hole } \\
\text { C0006D }\end{array}$ & $\begin{array}{c}\text { Hole } \\
\text { C0006E }\end{array}$ & $\begin{array}{c}\text { Hole } \\
\text { C0006F }\end{array}$ & $\begin{array}{c}\text { Hole } \\
\text { C0006C }\end{array}$ & $\begin{array}{c}\text { Hole } \\
\text { C0006D }\end{array}$ & $\begin{array}{c}\text { Hole } \\
\text { C0006E }\end{array}$ & $\begin{array}{c}\text { Hole } \\
\text { C0006F }\end{array}$ \\
\hline 577.8 & & & & 572.3 & & & & -5.5 \\
\hline 597.9 & & & & 591.4 & & & & -6.5 \\
\hline
\end{tabular}

Notes: Hole C0006B logs are from LWD data acquired during IODP Expedition 314. Hole C0006C, C0006D, C0006E, and C0006F logs are from MSCL-W data from whole-round cores. LSF = LWD depth below seafloor, CSF-B = core depth below seafloor, IODP Method B (see the "Expedition 316 methods" chapter). 